\title{
ANALYSIS OF FRACTURES IN VOLCANIC CORES FROM PAHUTE MESA, NEVADA TEST SITE
}

by

Sigmund L. Drellack, Jr. and Lance B. Prothro, Bechtel Nevada

Keith E. Roberson, IT Corportation

Brad A. Schier, Daniel B. Stevens and Associates

Edwin H. Price, HSI GeoTrans, Inc.

September 1997

DISTRIBUTION OF THIS DOCUAENT IS UNLLMITED

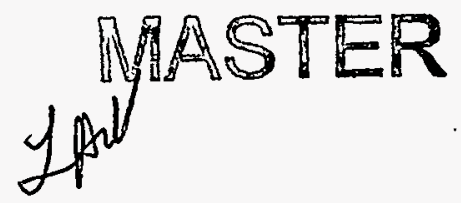




\section{DISCLAIMER}

This report was prepared as an account of work sponsored by an agency of the United States Government. Neither the United States Government nor any agency thereof, nor any of their employees, makes any warranty, express or implied, or assumes any legal liability or responsibility for the accuracy, completeness, or usefulness of any information, apparatus, product, or process disclosed, or represents that its use would not infringe privately owned rights. Reference herein to any specific commercial product, process, or service by trade name, trademark, manufacturer, or otherwise does not necessarily constitute or imply its endorsement, recommendation, or favoring by the United States Government or any agency thereof. The views and opinions of authors expressed herein do not necessarily state or reflect those of the United States Government or any agency thereof. 


\section{DISCLAIMER}

Portions of this document may be illegible electronic image products. Images are produced from the best available original document. 


\section{Table of Contents}

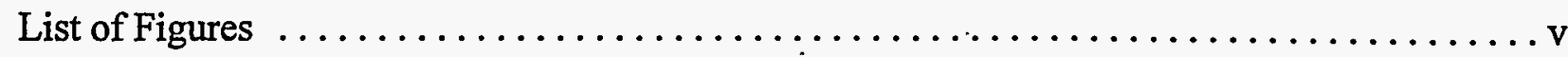

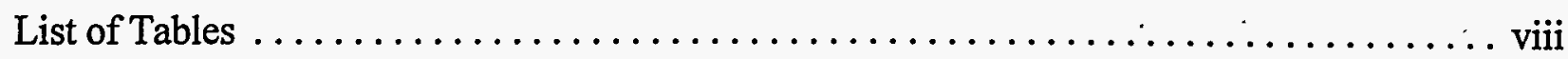

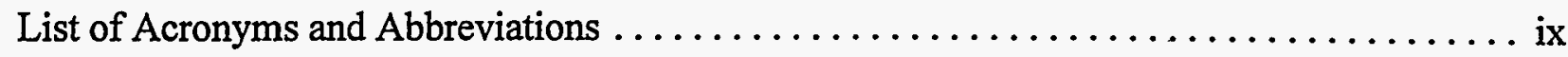

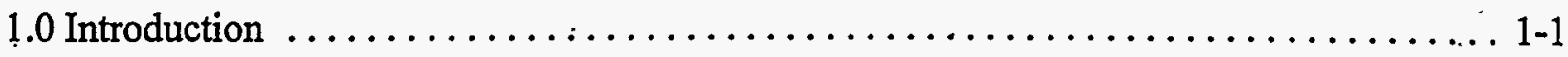

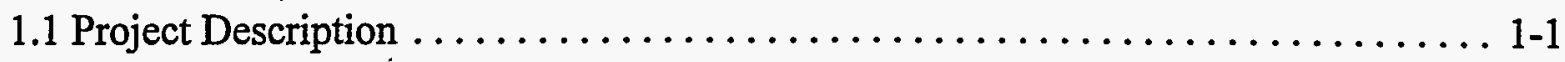

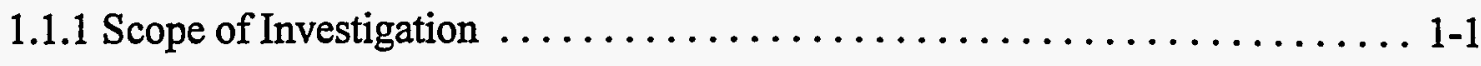

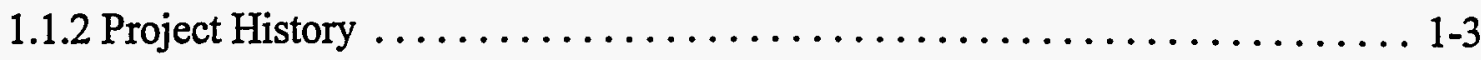

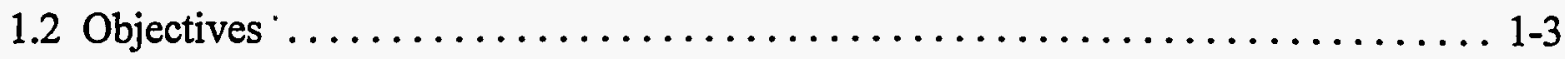

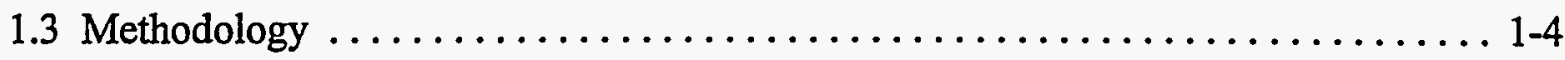

1.3.1 Core Fracture Analysis $\ldots \ldots \ldots \ldots \ldots \ldots \ldots \ldots \ldots \ldots \ldots \ldots \ldots \ldots .4$

1.3.2 Borehole Image Log Analysis $\ldots \ldots \ldots \ldots \ldots \ldots \ldots \ldots \ldots \ldots \ldots \ldots \ldots . .6$

1.3.3 Comparison of Geophysical Logs and Hydrologic Data with Fracture Data . 1-8

1.3.4 Literature Search ......................... 1-8

1.4 Summary of Pahute Mesa and Timber Mountain Hydrogeology $\ldots \ldots \ldots \ldots \ldots$ 1-8

2.0 Fracture Analysis for Selected Drill Holes $\ldots \ldots \ldots \ldots \ldots \ldots \ldots \ldots \ldots \ldots \ldots .2-1$

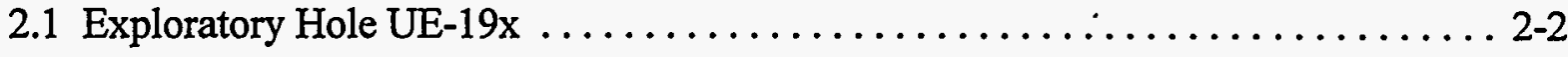

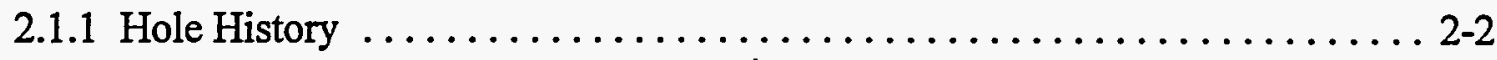

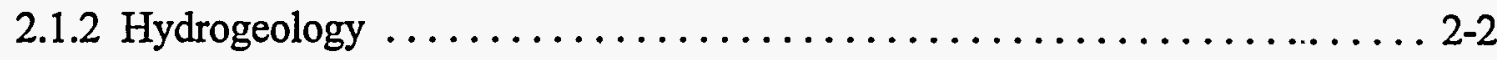

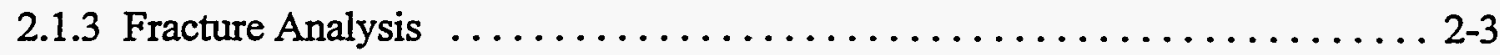

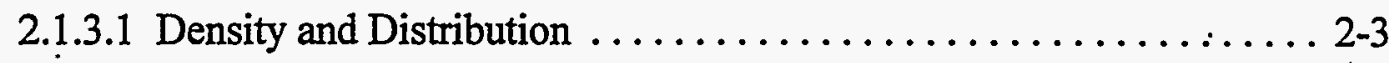

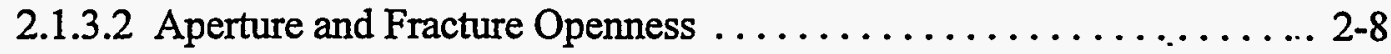

2.1.3.3 Mineralogy of Fracture Coatings $\ldots \ldots \ldots \ldots \ldots \ldots \ldots \ldots .2-9$

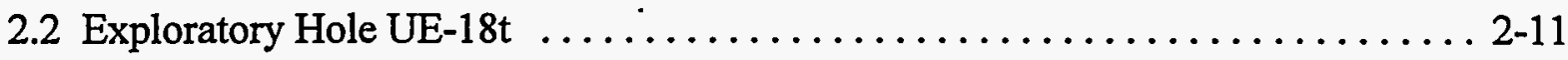

2.2 .1 Hole History $\ldots \ldots \ldots \ldots \ldots \ldots \ldots \ldots \ldots \ldots \ldots \ldots \ldots \ldots \ldots .2-11$

2.2 .2 Hydrogeology $\ldots \ldots \ldots \ldots \ldots \ldots \ldots \ldots \ldots \ldots \ldots \ldots \ldots \ldots \ldots .2-11$ 


\section{Table of Contents (Continued)}

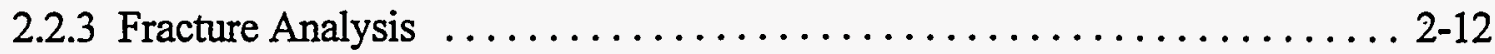

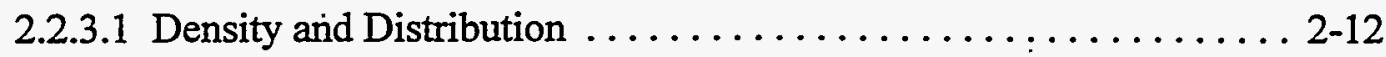

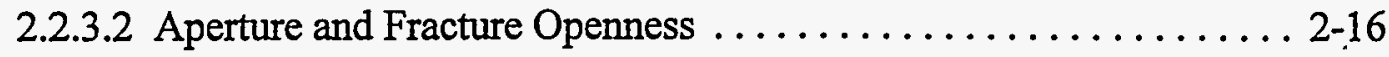

2.2.3.3 Mineralogy of Fracture Coatings ................. 2-16

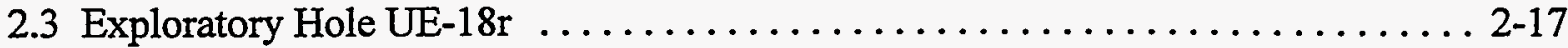

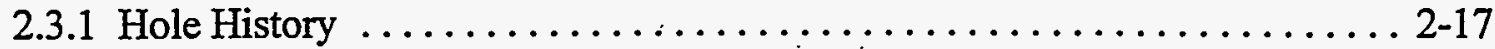

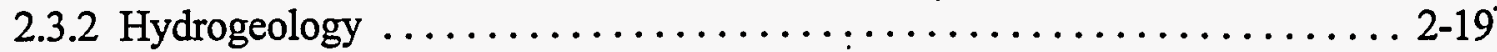

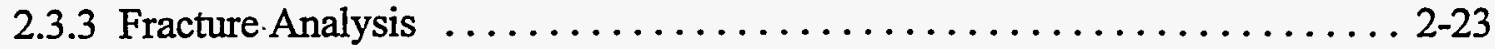

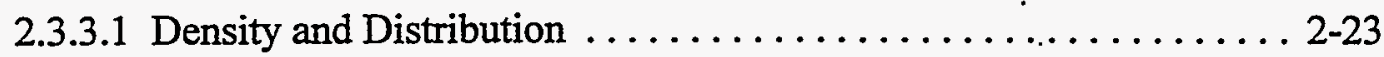

2.3.3.2 Aperture and Fracture Openness $\ldots \ldots \ldots \ldots \ldots \ldots \ldots \ldots \ldots .2-25$

2.3.3.3 Mineralogy of Fracture Coatings .................. 2-26

2.3.4 Comparisons of Fracture Data, Available Hydraulic Test Data, and

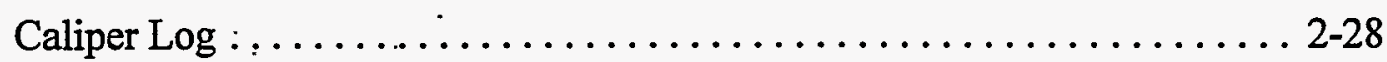

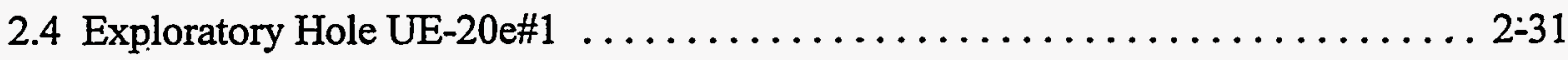

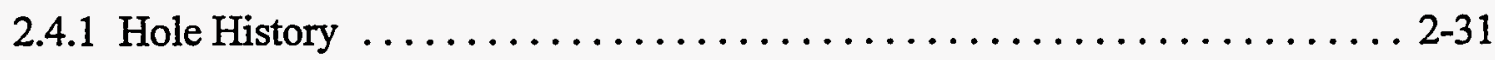

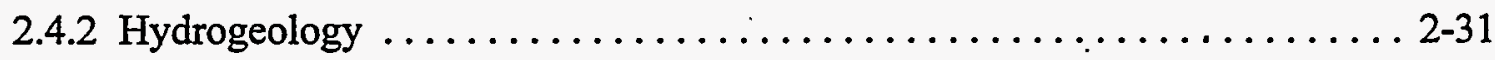

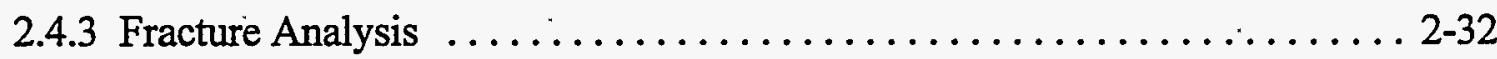

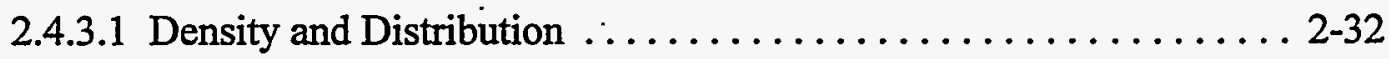

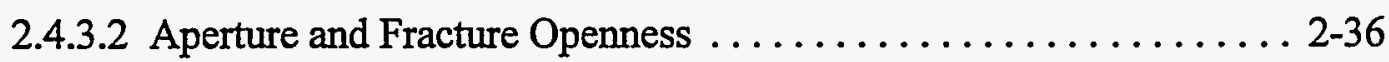

2.4.3.3 Mineralogy of Fracture Coatings .................. 2-37

2.4.4 Comparison of Fracture Data, Available Hydraulic Test Data, and

Caliper Logs ............................ 2-37

2.5 Monitoring Well UE-20bh\#1 $\ldots \ldots \ldots \ldots \ldots \ldots \ldots \ldots \ldots \ldots \ldots \ldots \ldots \ldots \ldots \ldots \ldots \ldots .41$

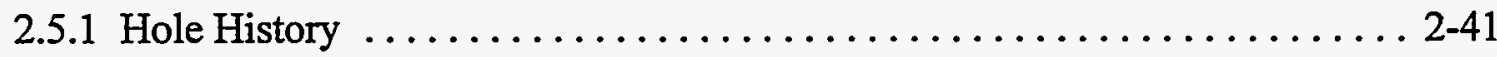

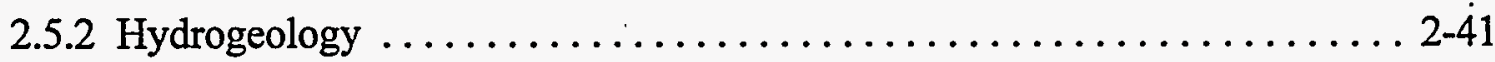

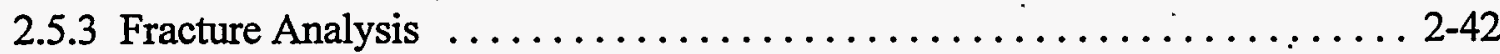

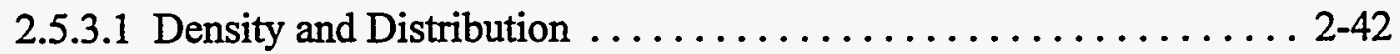

2.5.3.2 Aperture and Fracture Openness ................ 2-46

2.5.3.3 Mineralogy of Fracture Coatings ................. 2-47

2.5.4 Comparison of Fracture Data, Available Hydrologic Test Data, and

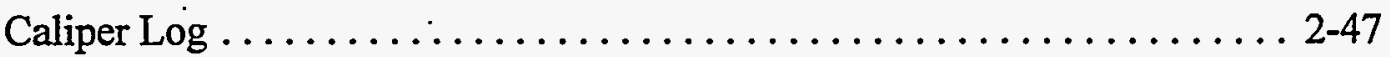




\section{Table of Contents (Continued)}

2.6 Emplacement Hole U-20c and Exploratory Hole UE-20c $\ldots \ldots \ldots \ldots \ldots . . .2-49$

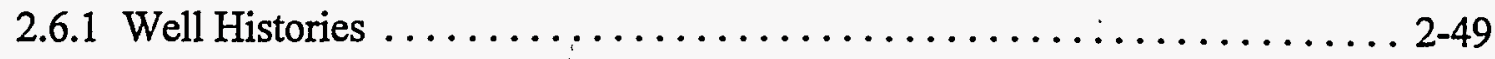

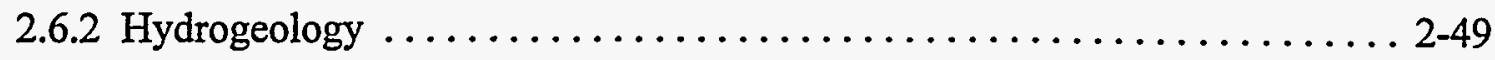

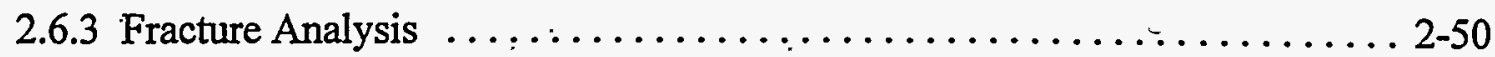

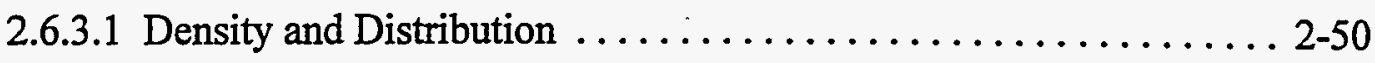

2.6.3.2 Aperture and Fracture Openness ................... 2-56

2.6:3.3 Mineralogy of Fracture Coatings .................. 2-55

2.6.4 Fracture Data Comparisons with Available Hydrologic Test Data . . . . . 2-55

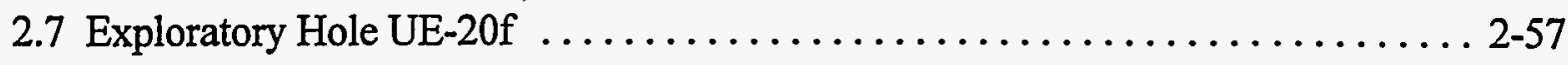

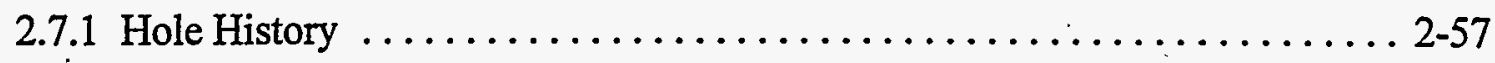

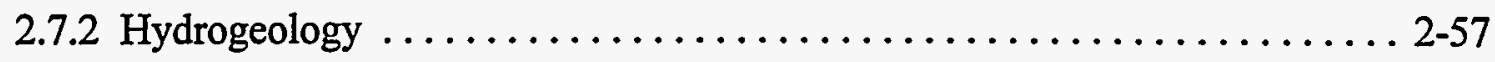

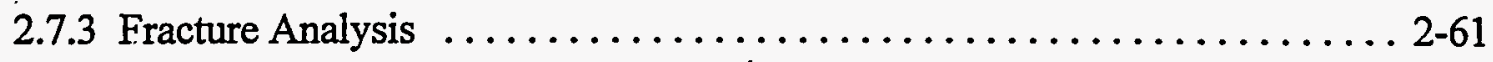

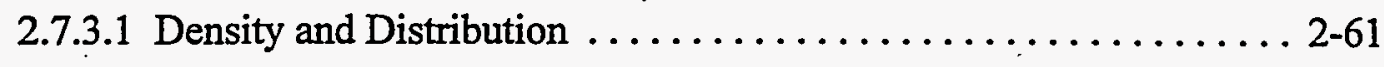

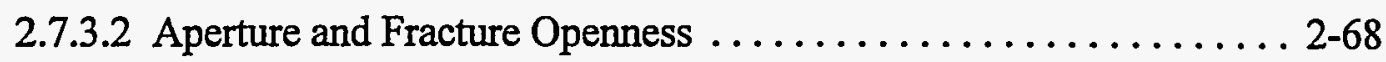

2.7.3.3 Mineralogy of Fracture Coatings .................. 2-69

2.7.4 Comparison of Fracture Data, Available Hydrologic Test Data, and

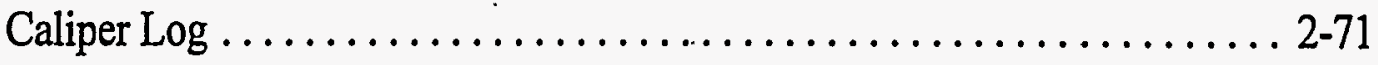

3.0 Borehole Image Log Analysis for Selected Drill Holes $\ldots \ldots \ldots \ldots \ldots \ldots \ldots . . \ldots .1$

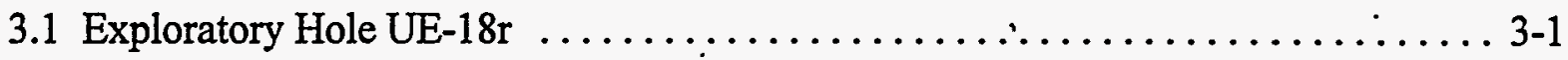

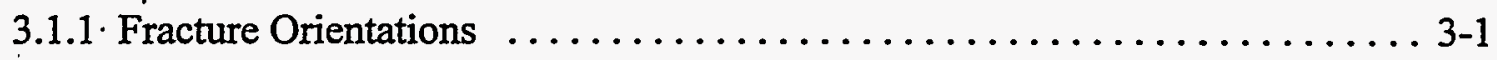

3.1.2 Comparison of the FMS Image with Core $\ldots \ldots \ldots \ldots \ldots \ldots \ldots \ldots .4$

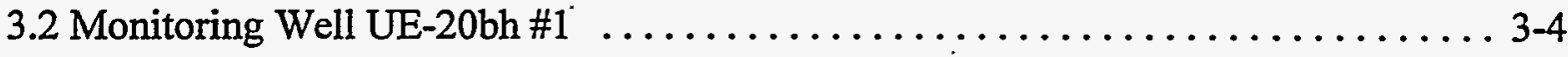

3.2.1 Fracture Orientations in UE-20bh \#1 $\ldots \ldots \ldots \ldots \ldots \ldots \ldots \ldots \ldots . . \ldots \ldots$

3.2.2 Comparison of the UE-20bh \#1 Wellbore Images with Core ......... 3-6

3.3 Well ER-20-5 $\# 1$.................................. 3-6

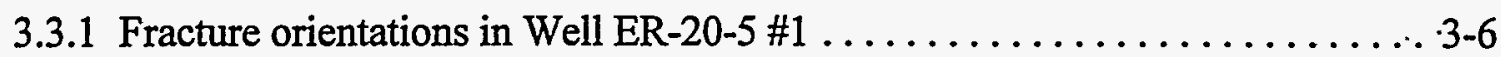

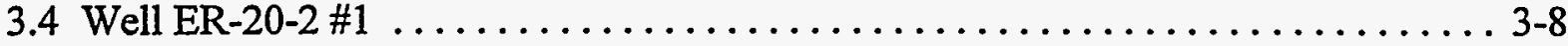

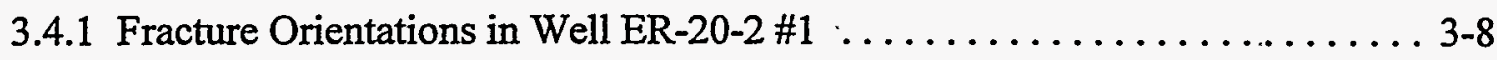

3.5 Synopsis of the Fracture Orientation of the Data Sets $\ldots \ldots \ldots \ldots \ldots \ldots \ldots \ldots .8$ 
4.0 Cumulative Analysis of Fracture Data $\ldots \ldots \ldots \ldots \ldots \ldots \ldots \ldots \ldots \ldots \ldots . \ldots \ldots \ldots .1$

4.1 General Observations of Fracture Attributes . . . . . . . . . . . . . . . . .

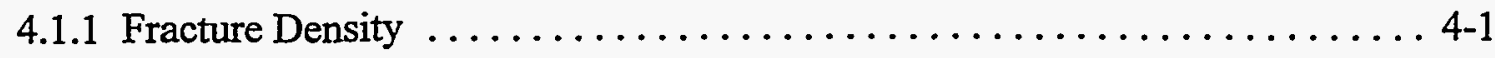

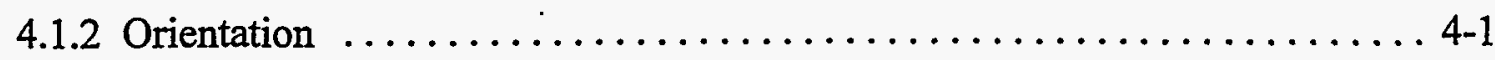

4.1 .3 Aperture and Openness ............................ 4-4

4.1.4 Mineralogy of Fracture Coatings $\ldots \ldots \ldots \ldots \ldots \ldots \ldots \ldots \ldots \ldots .4$

4.2 Fracture Attributes Within Hydrostratigraphic Units $\ldots \ldots \ldots \ldots \ldots \ldots \ldots \ldots .4 .4$

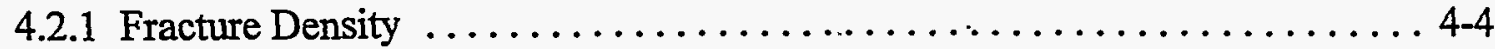

4.2.2 Aperture and Openness ......................... 4

4.2.3 Mineralogy of Fracture Coatings $\ldots \ldots \ldots \ldots \ldots \ldots \ldots \ldots \ldots \ldots, 4-7$

4.3 Fracture Attributes Within Hydrogeologic Units $\ldots \ldots \ldots \ldots \ldots \ldots \ldots \ldots .4 .10$

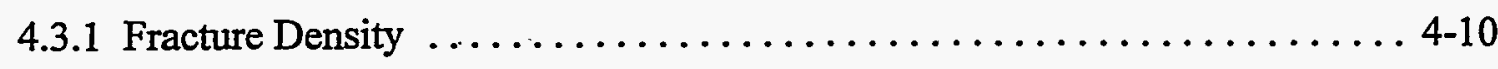

4.3.2 Aperture and Openness $\ldots \ldots \ldots \ldots \ldots \ldots \ldots \ldots \ldots \ldots \ldots \ldots \ldots .4 .10$

4.3.3 Mineralogy of Fracture Coatings $\ldots \ldots \ldots \ldots \ldots \ldots \ldots \ldots \ldots \ldots .4 .14$

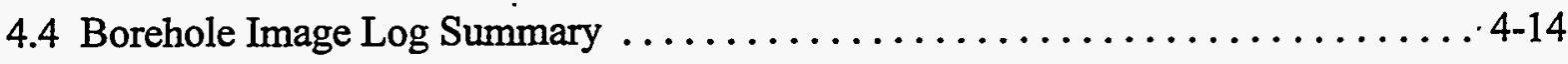

4.5 Comparison of Fracture Data, Available Hydrologic Test Data, and

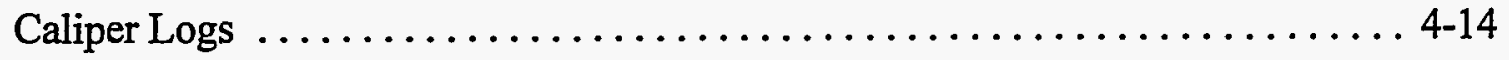

5.0 Summary and Recommendations for Further Study $\ldots \ldots \ldots \ldots \ldots \ldots \ldots \ldots \ldots$ 5-1

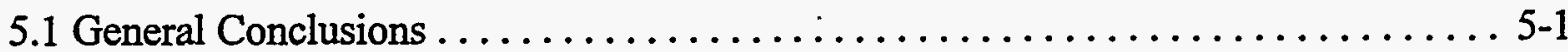

5.2 Recommendations for Further Study $\ldots \ldots \ldots \ldots \ldots \ldots \ldots \ldots \ldots \ldots \ldots, 2$

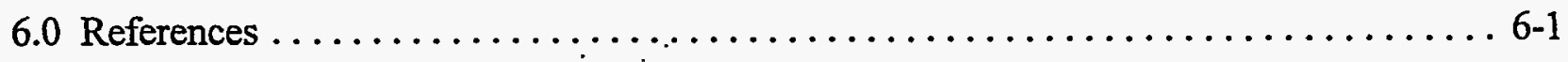

Appendix A - Mineralogy Information $\ldots \ldots \ldots \ldots \ldots \ldots \ldots \ldots \ldots \ldots \ldots \ldots \ldots \ldots \ldots \ldots \ldots \ldots \ldots \ldots$

Appendix B - Annotated Bibliography of Nevada Test Site Fracture Data . . . . . . . B-1

Appendix C - Drill Hole Data $\ldots \ldots \ldots \ldots \ldots \ldots \ldots \ldots \ldots \ldots \ldots \ldots \ldots \ldots \ldots \ldots \ldots \ldots \ldots$ 


\section{List of Figures}

Number

Title

Page

1-1 Location Map for Drill Holes Used in This Report $\ldots \ldots \ldots \ldots \ldots \ldots \ldots \ldots$ 1-2

2-1 UE-19x: Composite Log of Open and Closed Fracture Data, 4.6 Meters - TD . . 2-5

2-2a-d Density and Distribution of Fractures at UE-19x $\ldots \ldots \ldots \ldots \ldots \ldots \ldots \ldots \ldots \ldots$

2-3a-c Distribution of Fracture-Coating Minerals at Exploratory Hole UE-19x $\ldots \ldots$ 2-10

2-4 UE-18t: Composite Log of Open Fracture Data, 256 Meters - TD . . . . . . . 2-13

2-5a-c Density and Distribution of Fractures at Exploratory Hỏle UE-18t $\ldots \ldots \ldots$ 2-15

2-6a-b Distribution of Fracture Mineral Coatings at UE-18t $\ldots \ldots \ldots \ldots \ldots \ldots \ldots .2-18$

2-7 UE-18r: Composite Log of Open and Closed Fracture-Data, 117.3 Meters - TD . . . . . . . . . . . . . . 21

2-8a-d Density and Distribution of Fractures at Exploratory Hole UE-18r . . . . . . 2-24

2-9a-c Distribution of Fracture Mineral Coatings at UE-18r $\ldots \ldots \ldots \ldots \ldots \ldots .2-27$

2-10 UE-18r: Composite Log of Hydrologic Test Data, Caliper Log, and Fracture Data, 402.3 Meters - TD ...................... 2-29

2-11 UE-20e \#1: Composite Log of Open and Closed Fracture Data, $1,182.6$ Meters - TD . . . . . . . . . . . . $2-33$

2-12a-c Density and Distribution of Fractures at UE-20e\#1 $\ldots \ldots \ldots \ldots \ldots \ldots \ldots \ldots .2-35$

2-13a-b Distribution of Fracture Mineral Coatings at UE-20e $\# 1 \ldots \ldots \ldots \ldots \ldots \ldots$ 2-38

2-14. UE-20e \#1: Composite Log of Hydrologic Test Data, Caliper Log, and Fracture Data, 1,115.6 - 1,524 Meters ...................... 2-39

2-15 UE-20bh \#1: Composite Log of Open and Closed Fracture Data, 635.5 - 827.5 Meters ................................. 2-43

2-16a-c Density and Distribution of Fractures at UE-20bh \#1 $\ldots \ldots \ldots \ldots \ldots \ldots \ldots .45$

2-17a-b Distribution of Fracture Mineral Coatings at UE-20bh\#1 $\ldots \ldots \ldots \ldots \ldots$ 2-48 


\section{List of Figures (Continued)}

2-18 UE-20c: Composite Log of Open Fracture Data, 685.8 Meters - TD . . . . . . 2-51.

2-19a-c Density and Distribution of Fractures at U-20c/UE-20c $\ldots \ldots \ldots \ldots \ldots \ldots$ 2-53

2-20a-b Distribution of Fracture Mineral Coatings at U-20c/UE-20c $\ldots \ldots \ldots \ldots \ldots$ 2-56

2-21 UE-20c: Composite Log of Hydrologic Test Data and Fracture Data, $1,286.3-1,618.5$ Meters . . . . . . . . . . . . . . . . . . . 59

2-22 UE-20f: Composite Log of Open Fracture Data, 774.2 - 2,493.3 Meters . . . . . 2-63

2-23 UE-20f: Composite Log of Open Fracture Data, 2,493.3 - 4,171.5 Meters . . . 2-65

2-24a-c Density and Distribution of Fractures at UE-20f $\ldots \ldots \ldots \ldots \ldots \ldots \ldots \ldots \ldots$ 2-67

2-25à-b Distribution of Fracture Mineral Coatings at UE-20f $\ldots \ldots \ldots \ldots \ldots \ldots \ldots$ 2-70

2-26 UE-20f: Composite Log of Hydrologic Test Data, Caliper Log, and Fracture Data, $807.7-2,773.7$ Meters $\ldots \ldots \ldots \ldots \ldots \ldots \ldots \ldots \ldots \ldots \ldots \ldots \ldots \ldots \ldots \ldots \ldots .73$

3-1a-d Diagrams Showing Fracture Orientations in Exploratory Hole UE-18r by Depth Interval $\ldots \ldots \ldots \ldots \ldots \ldots \ldots \ldots \ldots \ldots \ldots \ldots \ldots \ldots \ldots \ldots \ldots \ldots \ldots \ldots, 3-2$

3-1e-h Diagrams Showing Fracture Orientations in Exploratory. Hole UE-18r by Depth Interval $\ldots \ldots \ldots \ldots \ldots \ldots \ldots \ldots \ldots \ldots \ldots \ldots \ldots \ldots \ldots \ldots \ldots \ldots, 3$

3-2a-c Diagrams Showing Fracture Orientations in Monitoring Well UE-20bh \#1 . . . . 3-5

3-3a-c Fracture Orientation Diagrams for Well ER-20-5 \#1 $\ldots \ldots \ldots \ldots \ldots \ldots \ldots$ 3-7

3-4a-b Fracture Orientation Diagrams for Well ER-20-2 \#1 $\ldots \ldots \ldots \ldots \ldots \ldots \ldots . . \ldots$

3-5 Composite Fracture Strikes for the Pahute Mesa Area $\ldots \ldots \ldots \ldots \ldots \ldots$ 3-10

4-1 Summary of Fracture Density $\ldots \ldots \ldots \ldots \ldots \ldots \ldots \ldots \ldots \ldots \ldots, 4,2$

4-2a-c Summary of Fracture Distribution Relative to Orientation $\ldots \ldots \ldots \ldots \ldots \ldots$ 4-3

4-3a-c Summary of the Distribution of Fracture-Mineral Coatings $\ldots \ldots \ldots \ldots \ldots$ 4-5

4-4a-c Summary of Fracture Density Relative to Hydrostratigraphy $\ldots \ldots \ldots \ldots \ldots$ 4-6

4-5a-c Summary of the Distribution of Fracture Mineral Coatings Within the TMA . . . 4-9 


\section{List of Figures (Continued)}

4-6a-c Summary of the Distribution of Fracture Mineral Coatings Relative to Hydrostratigraphy $\ldots \ldots \ldots \ldots \ldots \ldots \ldots \ldots \ldots \ldots \ldots \ldots \ldots \ldots . \ldots \ldots .11$

4-7a-c Summary of Fracture Density Relative to Hydrogeology $\ldots \ldots \ldots \ldots \ldots$. . 4-12

4-8a-d Summary of the Distribution of Fracture-Coating Minerals Relative to Hydrogeology . . . . . . . . . . . . . . . . . . . . 15 


\section{List of Tables}

Number

Title

Page

1-1 Hydrogeologic Information for Selected Boreholes in the Pahute Mesa Fracture

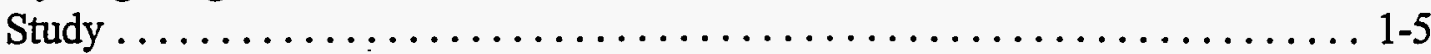

1-2 Definitions of Terms Used in the Core Fracture Analyses . . . . . . . . . . 1-7

1-3 Hydrogeologic Nomenclature Used in this Report $\ldots \ldots \ldots \ldots \ldots \ldots \ldots$ 1-10

1-4 Hydrostratigraphy of the Pahute Mesa/Timber Mountain Area . . . . . . . . . 1-11

1-5 Amount of Core Examined for this Fracture Study Grouped by Hydrostratigraphic Units $\ldots \ldots \ldots \ldots \ldots \ldots \ldots \ldots \ldots \ldots \ldots \ldots \ldots . .1-11$

1-6 Amount of Core Examined for This Fracture Study Grouped by

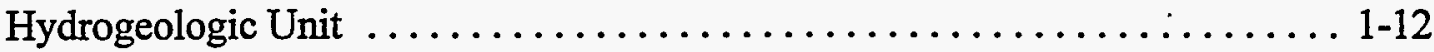

2-1 UE-19x Fracture Aperture and Percent Open Data $\ldots \ldots \ldots \ldots \ldots \ldots \ldots .2-8$

2-2 UE-18t Fracture Aperture and Percent Open Data ............... 2-17

2-3 UE-18r Fracture Aperture and Percent Open Data $\ldots \ldots \ldots \ldots \ldots \ldots \ldots .2-25$

2-4 UE-20e\#1 Fracture Aperture and Percent Open Data $\ldots \ldots \ldots \ldots \ldots \ldots .2-36$

2-5 UE-20bh \#1 Fracture Aperture and Percent Open Data $\ldots \ldots \ldots \ldots \ldots \ldots .2-46$

2-6 U-20c/UE-20c Fracture Aperture and Percent Open Data $\ldots \ldots \ldots \ldots \ldots$ 2-54

2-7 UE-20f Fracture Aperture and Percent Open Data ................ 2-69

4-1 Fracture Aperture and Percent Open Data Summary $\ldots \ldots \ldots \ldots \ldots \ldots \ldots$ 4-8

4-2 Fracture Aperture and Percent Open Data Summary $\ldots \ldots \ldots \ldots \ldots \ldots$. 4 -13 


\section{List of Acronyms and Abbreviations}

$\begin{array}{ll}\text { BAQ } & \text { Basal Aquifer } \\ \text { BCU } & \text { Basal Confining Unit } \\ \text { BHTV } & \text { Borehole televiewer } \\ \text { BN } & \text { Bechtel Nevada } \\ \text { CAU } & \text { Corrective Action Unit } \\ \text { DOE/NV } & \text { U.S. Department of Energy, Nevada Operations Office } \\ \text { Fe/Mn } & \text { Iron and Manganese oxides } \\ \text { FMS } & \text { Formation MicroScanner } \\ \text { ft } & \text { Foot (feet) } \\ \text { gpm } & \text { Gallon(s) per minute } \\ \text { gpm/ft } & \text { Gallon(s) per minute per foot } \\ \text { HGU } & \text { Hydrogeologic unit(s) } \\ \text { HRMP } & \text { Hydrologic Radionuclide Monitoring Program } \\ \text { HSU } & \text { Hydrostratigraphic unit(s) } \\ \text { ID } & \text { Identify } \\ \text { in. } & \text { Inch(es) } \\ \text { IT } & \text { International Technology Corporation } \\ \text { km } & \text { Kilometer(s) } \\ \text { LFA } & \text { Lava-flow aquifer } \\ \text { m } & \text { Meter(s) } \\ \text { mm } & \text { millimeter(s) } \\ \text { NTS } & \text { Nevada Test Site } \\ \text { TBA } & \text { Belted Range Aquifer } \\ \text { TC } & \text { Tuff Cone } \\ \text { TCB } & \text { Bullfrog Confining Unit } \\ \text { TCU } & \text { Tuff confining unit } \\ \text { TD } & \text { Total depth } \\ \text { TMA } & \text { Timber Mountain Aquifer } \\ \text { UGTA } & \text { Underground Test Area } \\ \text { USGS } & \text { U.S. Geological Survey } \\ \text { VTA } & \text { Vitric-tuff aquifer } \\ \text { WTA } & \text { Welded-tuff aquifer } \\ \text { YMP } & \text { Yucca Mountain Project } \\ & \end{array}$


This Page Intentionally Left Blank. 


\subsection{Introduction}

The Neyada Test Site (NTS), located in Nye County, southern Nevada, was the location of 828 announced underground nuclear tests, conducted between 1951 and 1992 (DOE, 1994). Approximately one-third of these tests were detonated near or below the water table (Laczniak et al., 1996). An unavoidable consequence of these testing activities was introducing radionuclides into the subsurface environment, impacting groundwater. Groundwater flows beneath the NTS almost exclusively through interconnected natural fráctures in carbonate and volcanic rocks (Blankennagle and Weir, 1973; GeoTrans, 1995). Information about these fractures is necessary to determine hydrologic parameters for future Corrective Action Unit (CAU)-specific flow and transport models which will be used to support risk assessment calculations for the U.S. Department of Energy, Nevada Operations Office (DOE/NV) Underground Test Area (UGTA) remedial investigation. Fracture data are critical in reducing the uncertainty of the predictive capabilities of CAU-specific models because of their usefulness in generating hydraulic conductivity values and dispersion characteristics used in transport modeling. Specifically, fracture aperture and density (spacing) are needed to calculate the permeability anisotropy of the formations. Fracture mineralogy information is used qualitatively to evaluate diffusion and radionuclide retardation potential in transport modeling. All these data can best be collected through examination of core samples.

\subsection{Project Description}

\subsubsection{Scope of Investigation}

Fracture data from cores collected from eight drill holes in the Pahute Mesa/Timber Mountain area are presented in this report. Fracture analyses were performed on two continuous cores from drill holes UE-18t and UE-19x and core segments from six other drill holes (UE-18r, U-20c, UE20c, UE-20e\#1, UE-20f, and UE-20bh\#1). Also, fracture analyses using borehole televiewer (BHTV) and Formation MicroScanner ${ }^{\text {TM }}$ (FMS) data were performed on four wells (UE-18r, UE20bh\#1, ER-20-2\#1, and ER-20-5\#1), two of which (ER-20-2\#1 and ER-20-5\#1) were not cored. The locations of these wells on the NTS is shown in Figure 1-1. The data analyzed relate to several attributes of the fractures, including distribution, density, aperture, openness, roughness, orientation, and fracture-lining mineralogy. These attributes have been compared against hydrogeology and hydrostratigraphy, and the resulting information can be used to generate values for hydrologic model inputs such as hydraulic conductivity and radionuclide retardation. 


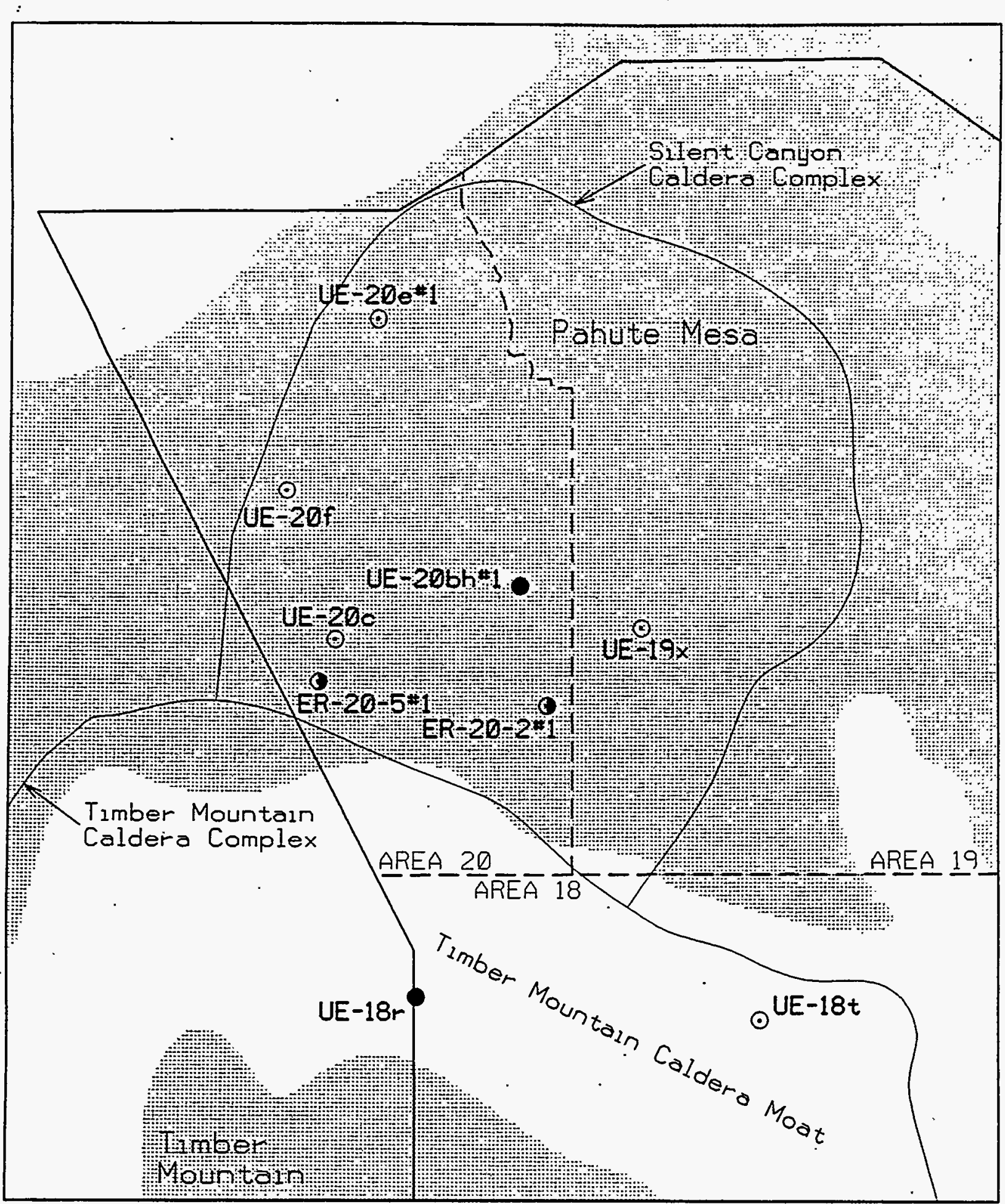

EXPLANATION

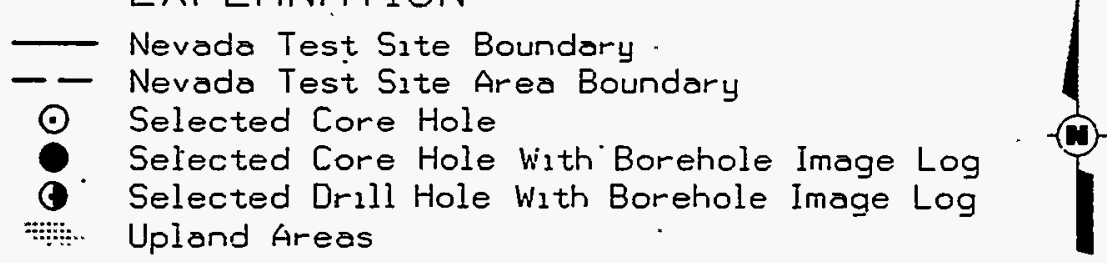

Figure 1-1

Location Map for Drill Holes Used in This Report 
This report is presented as a compilation of data and is intended to be used for future CAU-specific flow and transport models.

\subsubsection{Project History}

This report is an account of work accomplished in late 1995 and early 1996, which was documented in a draft report distributed by IT Corporation (IT) for limited external review in April 1996 (IT, 1996a). Reviewers' comments have been addressed in this final report, but the scope and conclusions have not changed significantly from those presented in the IT draft publication.

The hydrostratigraphic nomenclature used in this report follows that used for the UGTA Phase I regional groundwater modeling efforts (IT, 1996b). However, hydrogeologic characterization of the NTS area is a continuing process, and changes in the definitions of șome hydrostratigraphic units have occurred as a result of work conducted after publication of the draft report that forms the basis of this document (IT, 1996a). These changes have not been incorporated into this final report.

Conclusions from the data presented in this fracture analysis report have, however, been assimilated into subsequent reports. For a more in-depth look at the hydrostratigraphy of the Pahute Mesa study area, the reader is directed to these recent works, which include Drellack and Prothro (1997) and Prothro and Drellack (1997).

\subsection{Objectives}

The objective of this study was to obtain information about fractures in volcanic hydrogeologic and hydrostratigraphic units at Pahute Mesa to determine important hydrologic parameters for future CAU-specific flow and transport models. Critical fracture information gathered during this study included:

- Fracture density

- Aperture

- Orientation

- Secondary mineral coatings 


\subsection{Methodology}

\subsubsection{Core Fracture Analysis}

A core fracture analysis was performed on conventional core samples from eight drill holes on or in the vicinity of Pahute Mesa. The drill holes were UE-18r, UE-18t, UE-19x, UE-20bh \#1, U-20c, UE-20c, UE-20e \#1, and UE-20f. A summary of pertinent information about these wells is presented in Table 1-1. These drill holes were selected because cummulatively they provide representative core through five of the six hydrostratigraphic units (HSUs) defined in the Phase I regional groundwater flow model, and they provide the opportunity to compare fractures in core to the BHTV and/or FMS borehole fracture logs.

A total of 1,578 meters (m) $(5,177$ feet [ft]) of core was examined from December 1995 to February 1996 by geologists from Bechtel Nevada Corporation (BN), IT Corporation, Daniel B. Stephens and Associates, and GeoTrans, Inc. This study was conducted at the U. S. Geological Survey's (USGS) Geologic Data Center and Core Library in Mercury, Nevada. Typically, core was examined megascopically; however, 10x- to 40x-zoom binocular microscopes were used routinely for more detailed examination. The fracture data collected during the fracture analysis as well as stratigraphic, lithologic, hydrogeologic, hydrostratigraphic, and geophysical information were entered into a StratiFact ${ }^{\circledR}$ database for graphical presentations and an Excel $^{\circledR}$ spreadsheet for statistical analysis. The data are on file at BN Geology/Hydrology in Mercury, Nevada, and at the IT office in Las Vegas, Nevada.

During this analysis, the lithology and stratigraphy of the cores were compared to available published logs. Relevant observations, such as degree of welding and alteration, were added as necessary. Stratigraphic nomenclature was also revised and updated as necessary to conform to the new southwestern Nevada volcanic field stratigraphic nomenclature (Ferguson et al., 1994).

A total of 2,851 natural fractures was examined during the analysis. Because only natural fractures were described, it was necessary to differentiate between natural fractures and breaks induced during coring or handling. The presence of secondary mineral coatings on fracture surfaces is generally indicative of a natural fracture; therefore, all breaks in the cores were carefully examined for the presence of secondary minerals. In addition, natural fractures are usually more planar and have smoother surfaces that commonly appear weathered or stained. Faults (as indicated by the presence of slickensides, gouge, or apparent relative displacement) 
Table 1-1

Hydrogeologic Information for Selected Boreholes in the Pahute Mesa Fracture Study

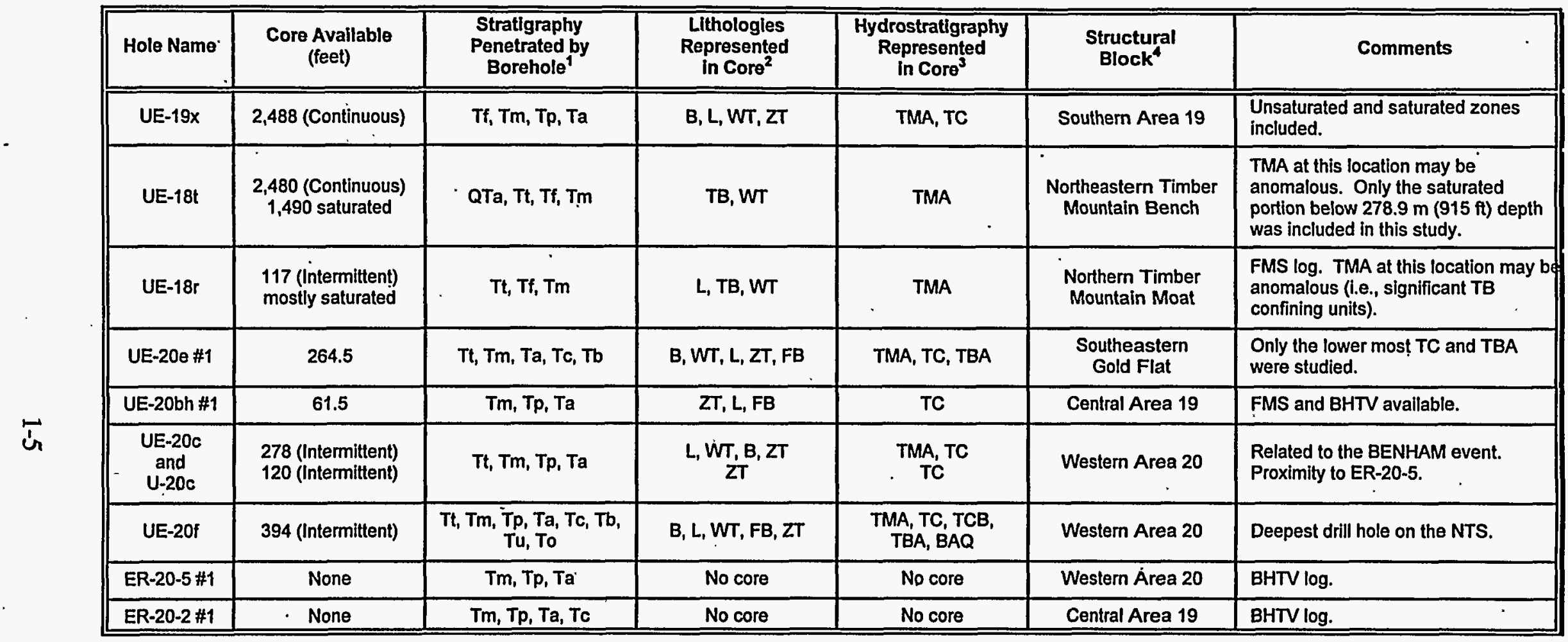

1 Stratigraphic symbols from Ferguson et al., 1994; also defined in Table C-22

2 Lithology nomenclature:

$$
\begin{array}{ll}
\text { B } & \text { Bedded tuff } \\
\text { FB } & \text { Flow breccia } \\
\text { L } & \text { Lava } \\
\text { NWT } & \text { Nonwelded tuff } \\
\text { TB } & \text { Tuff breccla } \\
\text { WT } & \text { Welded tuff } \\
\text { ZT } & \text { Zeolltized tuff }
\end{array}
$$

3 Hydrostratigraphic nomenclature from the simplified UGTA Phase I hydrogeologic model (Pahute Mesa units only)

$\begin{array}{lll}\text { TMA } & \text { Tlmber Mountain Aquifer } \\ \text { TC } & \text { Tuff Cone } \\ \text { TCB } & \text { Bulffrog Confining Unit } \\ \text { TBA } & \text { Belted Range Aquifer } \\ \text { BCU } & \text { Basal Confining Unit } \\ \text { BAQ } & \text { Basal Aquifer }\end{array}$

4 Structural block convention by Warren (1994) 
and cooling joints are defined as fractures in this data set. Faults were, however, noted on the data sheets so they can easily be separated from the larger data set if desired.

Both open and closed natural fractures were examined during the analysis; however, particular attention was given to open fractures because of their hydrologic significance. In the case of open fractures, the location of each fracture was typically recorded to the next whole foot. However, due to high total fracture density open fractures examined in drill hole UE-18t were recorded in five-foot intervals. All the fracture characteristics were recorded, including surface texture, the type of secondary mineral coating(s) present, an estimate of the percent of the fracture surfaces coated with secondary minerals, the measured dip of the fracture, an estimate of the representative aperture, an estimate of the percent of the fracture open, and any additional characteristics such as the shape of the fracture.

Closed fractures were recorded in either one- or five-foot $(0.3-$ or $1.5-\mathrm{m})$ intervals, depending on the drill hole and the abundance of fractures. At UE-18t, for example, fractures are very abundant (particularly closed fractures), so a five-foot $(1.5-\mathrm{m})$ recording interval was used for convenience. The attributes noted include the averaged measured dip, the secondary mineral(s) filling the fractures, and any additional characteristics. Table 1-2 summarizes the criteria used for defining fracture attributes that were analyzed in the study.

Twenty samples of secondary mineral coatings were collected and sent to Analytical Materials Laboratory, Santa Barbara, California, for mineralogical analysis. Field descriptions of the samples submitted are provided in Table A-1 in Appendix A. Samples were collected in accordance with the appropriate UGTA and/or DOE-approved procedures (BN, 1996; IT, 1995a and $b ; D O E, 1995)$. The methodology and results of the analysis are provided by Iyengar (1996) and included in Appendix A. In addition, select x-ray diffraction data reported by the USGS for drill holes. UE-18t (Byers et al., 1981) and UE-19x (Blackmon, 1978) were also incorporated into the study. Results from these analyses provided detailed and precise mineralogy impossible to obtain from visual observation alone. Forty-nine photographs were taken of select features and fractures, including the samples collected for mineralogical analysis. The photos serve as documentation for this study, but perhaps more importantly, they may be used as a visual reference in future studies. The photos are on file at the IT office in Las Vegas, Nevada. 
Table 1-2

\section{Definitions of Terms Used in the Core Fracture Analyses}

\begin{tabular}{|c|c|}
\hline Term & Definition Used in Study \\
\hline Fracture & A break or crack in a rock core. \\
\hline Natural Fracture & $\begin{array}{l}\text { A fracture resulting from natural geologic processes, including faults and cooling joints. } \\
\text { Natural fractures are usually coated or filled with secondary minerals. They are usually high- } \\
\text { to medium-angle (but seldom vertical and running down the center of the core), relatively } \\
\text { smooth and planar, and have a weathered or stained appearance. }\end{array}$ \\
\hline $\begin{array}{l}\text { Coring and Handling-Induced } \\
\text { Fracture }\end{array}$ & $\begin{array}{l}\text { A fracture resulting from stresses created during coring or handling. Coring and handling- } \\
\text { induced fractures will not have secondary mineral coatings and usually have rough textures, } \\
\text { curved to irregular shapes, and "fresh" appearances. }\end{array}$ \\
\hline Open Fracture & A natural fracture that has open space between the sides of the fracture. \\
\hline Closed Fracture & $\begin{array}{l}\text { A natural fracture that is completely filled with secondary minerals and, thus, has no open } \\
\text { space along the fracture trace in the core. }\end{array}$ \\
\hline Depth of Fracture & $\begin{array}{l}\text { The bottom of the one-foot or five-foot interval in which the fracture occurs (i.e., the depth of } \\
\text { the fracture recorded to the next whole foot or five-foot depth). }\end{array}$ \\
\hline Fracture Density & The number of fractures per vertical foot. \\
\hline $\begin{array}{l}\text { Fracture Orientation } \\
\qquad \begin{array}{r}\text { High-angle } \\
\text { Medium-angle } \\
\text { Low-angle }\end{array}\end{array}$ & $\begin{array}{l}\text { The dip of the fracture (i.e., the acute angle formed by the fracture and a horizontal plane } \\
\text { normal to the long axis of the core). } \\
\text { A fracture with a dip greater than } 60 \text { degrees and less than or equal to } 90 \text { degrees. } \\
\text { A fracture with a dip greater than } 30 \text { degrees and less than or equal to } 60 \text { degrees. } \\
\text { A fracture with a dip greater than or equal to } 0 \text { degrees and less than or equal to } 30 \text { degrees. }\end{array}$ \\
\hline Aperture & $\begin{array}{l}\text { A representative open distance in millimeters between the sides of the fracture, visually } \\
\text { estimated as representative for the portion of the fracture exposed in the core. }\end{array}$ \\
\hline Percent Open & $\begin{array}{l}\text { The estimated percent of the open space (i.e., aperture) along the entire visible portion of } \\
\text { the fracture. When only a single fracture surface was available for examination, estimate of } \\
\text { percent open was based on the abundance, distribution, and crystal size of the minerals } \\
\text { observed on the surface. }\end{array}$ \\
\hline Secondary Mineral Coatings & $\begin{array}{l}\text { Naturally occurring minerais that coat the surface of a fracture. Secondary mineralization } \\
\text { occurs after the formation of natural fractures, and, therefore, is indicative of natural } \\
\text { fractures. }\end{array}$ \\
\hline Percent Coated & The estimated percent of the fracture surface that is coated with secondary minerais. \\
\hline $\begin{array}{r}\text { Very Smooth } \\
\text { Smooth } \\
\text { Intermediate } \\
\text { Rough }\end{array}$ & $\begin{array}{l}\text { The feel and appearance of the sides (i.e., surfaces) of a fracture. Texture was described as } \\
\text { either very smooth, smooth, intermediate, or rough. } \\
\text { A fracture surface that is polished. The surface feels slick and appears glossy and shiny. } \\
\text { A fracture surface that has a very minor coarse feel and appearance. } \\
\text { A fracture surface that has a coarse and somewhat jagged feel and appearance. } \\
\text { A fracture surface that has a very coarse and jagged feel and appearance. }\end{array}$ \\
\hline Fracture Shape & $\begin{array}{l}\text { The general shape of the fracture plane. Fracture shape was described as either planar, } \\
\text { curved, or irregular. }\end{array}$ \\
\hline
\end{tabular}




\subsubsection{Borehole Image Log Analysis}

Oriented borehole image logs are tools for identifying and determining the in situ orientation of fractures that were penetrated by a borehole and are used when the strike of fractures is desired. There are two types of borehole image logs: the BHTV is an acoustic device operated by most logging companies, and the FMS is a micro-resistivity measuring tool, operated by Schlumberger. Both types have been used at the NTS.

Four drill holes used in this study had borehole image logs. Well UE-18r has an FMS log. Wells ER-20-2\#1 and ER-20-5-\#1 have BHTV logs, and Well UE-20bh\#1 has both BHTV and FMS logs available. Wells UE-18r and UE-20bh\#1 both have intermittent core for comparison with the image logs.

\subsubsection{Comparison of Geophysical Logs and Hydrologic Data with Fracture Data} In addition to the borehole image logs, other geophysical logs for the drill holes selected for this study were collected and evaluated. Because most of the holes were drilled more than twenty years ago, complete suites of logs were unavailable. However, most of the holes had a caliper log available that was used for comparison against the fracture data and the hydrologic test data. The results of these comparisons are reported in Section 2.0 and summarized in Section 4.4 of this report.

Available hydrologic test data were assembled and evaluated for the study wells. Comparisons were made between well hydrologic data and the fracture data derived from core fracture analysis, as reported in Section 2.0 and summarized in Section 4.5.

\subsubsection{Literature Search}

An extensive literature search of existing data about fractures at the NTS and vicinity was performed. An annotated bibliography of documents found during the search is provided in Appendix B. An effort was made to compare data from these other studies, and they are included and cited, where appropriate.

\subsection{Summary of Pahute Mesa and Timber Mountain Hydrogeology}

Pahute Mesa and Timber Mountain are physiographic features within the southwestern Nevada volcanic field. The rocks that underlie these areas consist chiefly of Miocene rhyolitic volcanic rocks that were erupted from several local nested and/or overlapping calderas that include the Silent Canyon and Timber Mountain caldera complexes (Figure 1-1). The Silent Canyon caldera complex underlies Pahute Mesa, which is bounded and truncated on its southern margin by the 
younger Timber Mountain caldera complex (Ferguson et al., 1994). Six of the wells used in this study (NTS Area 20 and Area 19 wells) were drilled on Pahute Mesa through extra-caldera ash flows that erupted from the Timber Mountain caldera onto older rocks of the Silent Canyon caldera complex. The other two wells (NTS Area 18 wells) were drilled into the Timber Mountain moat, a ring-shaped topographic depression filled with intra-caldera lava flows and ash flows erupted from the Timber Mountain caldera. The thickness of the lava flows and ash flows in these calderas approaches 5 kilometers (km) (Ferguson et al., 1994).

The Pahute Mesa/Timber Mountain area lies within the Alkali Flat-Furnace Creek Ranch subbasin (as defined by Waddell et al., 1984) of the regional Death Valley groundwater flow system. Groundwater flow within this regional system is generally to the south-southwest, from recharge occurring on Pahute Mesa and areas in central Nevada and intervening uplands to surface discharge areas at Oasis Valley, Alkali Flat, Death Valley, and Ash Meadows. Throughout the Pahute Mesa/Timber Mountain caldera complex area, volcanic rocks are interpreted to extend downward to the regional hydrologic "basement" (IT, 1996). Paleozoic carbonate rocks, which underlie much of the area and serve as the primary regional aquifer for the Death Valley groundwater flow system, are probably not present beneath the caldera complex. In the caldera complex, groundwater flows primarily through volcanic aquifers.

The volcanic rocks of the Pahute Mesa/Timber Mountain area have been subdivided, following two different classification schemes, into hydrogeologic units (HGUs) and hydrostratigraphic units. Both of these units are used throughout this report. HGUs are lithologic units defined on the basis of primary lithologic properties, degree of fracturing, and secondary mineral alteration, and are used to categorize lithologies about their ability to transmit groundwater. Four HGUs have been defined for the area and include the welded-tuff aquifer (WTA), the lava-flow aquifer (LFA), the vitric-tuff aquifer (VTA), and the tuff confining unit (TCU) (Blankennagle and Weir, 1973; Winograd and Thordarson, 1975; Laczniak et al., 1996; IT, 1996). More information about these HGUs is provided in Table 1-3.

HSUs are stratigraphic units formed by combining stratigraphic groups and formations on the basis of similar hydrogeologic properties. An HSU may consist of several HGUs, but is usually dominated by a single type of HGU (for example, mostly WTA and LFA, or mostly TCU). HSUs were defined to serve as layers for the regional (Phase I) groundwater modeling (IT, 1996). The volcanic strata in the Pahute Mesa/Timber Mountain area were subdivided into six HSUs: the Timber Mountain Aquifer (TMA), the Tuff Cone (TC), the Bullfrog Confining Unit 
Table 1-3

Hydrogeologic Nomenclature Used in this Report

\begin{tabular}{|c|l|l||}
\hline Hydrogeologic Unit & \multicolumn{1}{|c|}{ Typical Lithologies } & \multicolumn{1}{|c|}{ Hydrologic Significance } \\
\hline $\begin{array}{c}\text { Vitric-Tuff Aquifer } \\
\text { (VTA) }\end{array}$ & $\begin{array}{l}\text { Bedded tuffs; air-fall } \\
\text { and reworked tuffs; } \\
\text { unaltered, vitric to } \\
\text { devitrified }\end{array}$ & $\begin{array}{l}\text { Constitutes a volumetrically minor hydrogeologic } \\
\text { unit. Generally does not extend far below the static } \\
\text { water level due to tendency to become zeolitized } \\
\text { (which drastically reduces permeability) under } \\
\text { saturated conditions. Significant interstitial porosity } \\
\text { (20 to 40 percent). Generally insignificant fracture } \\
\text { permeability. }\end{array}$ \\
\hline $\begin{array}{c}\text { Welded-Tuff Aquifer } \\
\text { (WTA) }\end{array}$ & $\begin{array}{l}\text { Welded ash-flow tuff; } \\
\text { vitric to devitrified }\end{array}$ & $\begin{array}{l}\text { Either intra- or extra-caldera. Degree of welding } \\
\text { greatly affects interstitial porosity (less porosity as } \\
\text { degree of welding increases) and permeability } \\
\text { (greater fracture permeability as degree of welding } \\
\text { increases). Welded zones typically intercalated } \\
\text { between nonwelded zones. }\end{array}$ \\
\hline $\begin{array}{c}\text { Tuff Confining Unit } \\
\text { (TCU) }\end{array}$ & $\begin{array}{l}\text { Zeolitized bedded tuffs; } \\
\text { with interbedded, but } \\
\text { less significant, zeo- } \\
\text { litized, nonwelded to } \\
\text { partially welded ash- } \\
\text { flow tuffs }\end{array}$ & $\begin{array}{l}\text { May be saturated but measured transmissivities } \\
\text { are very low. Responsible for perched and/or } \\
\text { semiperched water in overlying units. }\end{array}$ \\
\hline $\begin{array}{l}\text { Lava-Flow Aquifer } \\
\text { (LFA) }\end{array}$ & $\begin{array}{l}\text { Rhyolite lava flows; } \\
\text { includes flow breccias } \\
\text { (commonly at base) } \\
\text { and pumiceous zones } \\
\text { (commonly at top) }\end{array}$ & $\begin{array}{l}\text { Generally a caldera-filling unit. Hydrologically } \\
\text { complex: wide range of transmissivities; fracture } \\
\text { density and interstitial porosity differ with lithologic } \\
\text { variations. Lateral and vertical continuity uncertain, } \\
\text { especially where intercalated with thick zeolitized } \\
\text { nonwelded tuffs (TCUs). }\end{array}$ \\
\hline \hline
\end{tabular}

Source: Adapted from Blankennagle and Weir (1973); Winograd and Thordarson (1973); IT (1996); and Laczniak et al. (1996).

(TCB), the Belted Range Aquifer (TBA), the Basal Confining Unit (BCU), and the Basal Aquifer (BAQ), as shown in Table 1-4. The TC exhibits the greatest lithologic heterogeneity and constitutes a large proportion of the saturated section of the caldera complex. Drill holes were selected to maximize coverage of the TC HSU. Tables 1-5 and 1-6 show the amounts of core examined in this study, grouped by HSU and HGU, respectively. 
Table 1-4

Hydrostratigraphy of the Pahute Mesa/Timber Mountain Area

\begin{tabular}{||l|l|l||}
\hline \multicolumn{1}{|c|}{ Hydrostratigraphic Unit (HSU) $^{1}$} & \multicolumn{1}{|c|}{ Properties } & \multicolumn{1}{c|}{ Stratigraphic Units ${ }^{2}$} \\
\hline \hline Timber Mountain Aquifer (TMA) & Uppermost welded tuffs & Tt, Tf, Tm, Tp \\
\hline Tuff Cone (TC) & $\begin{array}{l}\text { Laterally variable } \\
\text { tuffs and lava flows }\end{array}$ & Tp, Ta, Tc \\
\hline Bullfrog Confining Unit (TCB) & Nonwelded tuff & Tcb \\
\hline Belted Range Aquifer (TBA) & Welded tuffs above BCU & Tcbs, Tr, Tb, Tub . \\
\hline Basal Confining Unit (BCU) & Mostly nonwelded tuffs & Tr, Tq, Tn, Tub, To \\
\hline Basal Aquifer (BAQ) & Mostly welded tuffs & Tqm, To, Tit \\
\hline
\end{tabular}

1 UGTA Phase I nomenciature. See IT (1996b).

2 Refer to Table C-22 in Appendix $C$ for explanation of stratigraphic nomenclature.

Table 1-5

Amount of Core Examined for this Fracture Study Grouped by Hydrostratigraphic Units

\begin{tabular}{|c|c|c|c|c|c|c|c|}
\hline $\begin{array}{l}\text { Hydrostratigraphic } \\
\text { Unit }^{\text {(HSU) }}\end{array}$ & $\begin{array}{l}\text { UE-18r } \\
\text { meters } \\
\text { (feet) }\end{array}$ & $\begin{array}{l}\text { UE-18t } \\
\text { meters } \\
\text { (feet) }\end{array}$ & $\begin{array}{l}\text { UE-19x } \\
\text { meters } \\
\text { (feet) }\end{array}$ & $\begin{array}{c}\text { UE-20bh\#1 } \\
\text { meters } \\
\text { (feet) }\end{array}$ & $\begin{array}{c}\text { U-20c, UE-20c } \\
\cdot \quad \text { meters } \\
\text { (feet) }\end{array}$ & $\begin{array}{c}\text { UE- } \\
20 \text { e\#1 } \\
\text { meters } \\
\text { (feet) }\end{array}$ & $\begin{array}{l}\text { UE-20f } \\
\text { meters } \\
\text { (feet) }\end{array}$ \\
\hline TMA & $\begin{array}{l}35.7 \\
(117)\end{array}$ & $\begin{array}{c}513.6 \\
(1,685)\end{array}$ & $\begin{array}{l}295.0^{\circ} \\
(968)\end{array}$ & - & - & - & - \\
\hline TC & - & - & $\begin{array}{c}467.9 \\
(1,535)\end{array}$ & $\begin{array}{c}18.7 \\
(61.5)\end{array}$ & $\begin{array}{l}109.4 \\
(359)\end{array}$ & $\begin{array}{l}38.7 \\
(127)\end{array}$ & $\begin{array}{l}53.6 \\
(176)\end{array}$ \\
\hline TCB & - & - & - & - & - & - & $\begin{array}{l}33.2 \\
(109)\end{array}$ \\
\hline TBA & - & - & - & - & - & $\begin{array}{c}7.8 \\
(25.5)\end{array}$ & $\begin{array}{l}4.0 \\
(13)\end{array}$ \\
\hline $\mathrm{BCU}$ & - & $\dot{-}$ & - & - & - & - & \\
\hline$B A Q$ & - & - & - & - & - & - & $\begin{array}{l}4.9 \\
(16)\end{array}$ \\
\hline $\begin{array}{c}\text { Total } \\
578(5,177 \mathrm{ft})\end{array}$ & $\begin{array}{l}35.7 \\
(117)\end{array}$ & $\begin{array}{c}513.6 \\
(1,685)\end{array}$ & $\begin{array}{l}158.3 \\
(2,488)\end{array}$ & $\begin{array}{c}18.7 \\
(61.5)\end{array}$ & $\begin{array}{l}109.4 \\
(359)\end{array}$ & $\begin{array}{c}46.5 \\
(152.5)\end{array}$ & $\begin{array}{l}95.7 \\
(314)\end{array}$ \\
\hline
\end{tabular}

1 Refer to Table 1-4 for explanation of hydrostratigraphic nomenclature.

- Unit not represented in borehole or in logged core from borehole. 
Table 1-6

\section{Amount of Core Examined for This Fracture Study Grouped by Hydrogeologic Unit}

\begin{tabular}{|c|c|c|c|c|c|c|c|}
\hline $\begin{array}{c}\text { Hydrogeologic } \\
\text { Unit }\end{array}$ & $\begin{array}{c}\text { UE-18r } \\
\text { meters } \\
\text { (feet) }\end{array}$ & $\begin{array}{c}\text { UE-18t } \\
\text { meters } \\
\text { (feet) }\end{array}$ & $\begin{array}{l}\text { UE-19x } \\
\text { meters } \\
\text { (feet) }\end{array}$ & $\begin{array}{l}\text { UE-20bh\#1 } \\
\text { meters } \\
\text { (feet) }\end{array}$ & $\begin{array}{c}\text { U-20c, UE-20c } \\
\text { meters } \\
\text { (feet) }\end{array}$ & $\begin{array}{c}\text { UE-20e\#1 } \\
\text { meters } \\
\text { (feet) }\end{array}$ & $\begin{array}{l}\text { UE-20f } \\
\text { meters } \\
\text { (feet) }\end{array}$ \\
\hline VTA & $\begin{array}{l}11.9 \\
(39)\end{array}$ & $\begin{array}{l}121.3 \\
(398)\end{array}$ & $\begin{array}{l}100.6 \\
(330)\end{array}$ & - & - & - & $\begin{array}{l}3.0 \\
(10)\end{array}$ \\
\hline WTA & $\begin{array}{l}3.0 \\
(10)\end{array}$ & $\begin{array}{c}392.2 \\
(1,287)\end{array}$ & $\begin{array}{l}265.5 \\
(871)\end{array}$ & - & $\begin{array}{l}27.7 \\
(91)\end{array}$ & - & $\begin{array}{l}7.9 \\
(26)\end{array}$ \\
\hline LFA & $\begin{array}{l}6.7 \\
(22)\end{array}$ & - & $\begin{array}{l}207.6 \\
(681)\end{array}$ & $\begin{array}{l}1.2 \\
(4)\end{array}$ & $\begin{array}{r}4.6 \\
(15)\end{array}$ & $\begin{array}{c}9.6 \\
(31.5)\end{array}$ & $\begin{array}{l}16.5 \\
(54)\end{array}$ \\
\hline TCU & $\begin{array}{l}14.0 \\
(46)\end{array}$ & - & $\begin{array}{l}184.7 \\
(606)\end{array}$ & $\begin{array}{c}17.5 \\
(57.5)\end{array}$ & $\begin{array}{l}77.1 \\
(253)\end{array}$ & $\begin{array}{l}36.9 \\
(121)\end{array}$ & $\begin{array}{l}68.3 \\
(224)\end{array}$ \\
\hline Total & $\begin{array}{l}35.7 \\
(117)\end{array}$ & $\begin{array}{c}513.6 \\
(1,685)\end{array}$ & $\begin{array}{c}158.3 \\
(2,488)\end{array}$ & $\begin{array}{c}18.7 \\
(61.5)\end{array}$ & $\begin{array}{l}109.4 \\
(359)\end{array}$ & $\begin{array}{c}46.5 \\
(152.5)\end{array}$ & $\begin{array}{l}95.7 \\
(314)\end{array}$ \\
\hline
\end{tabular}

1 Refer to Table 1-3 for explanation of hydrogeologic nomenclature.

The correlation between HGUs and HSUs is indirect because HGUs are formed on the basis of lithology, and HSUs are groups of HGUs defined on the basis on stratigraphic position. For example, the WTA HGU for a given core consists of all the welded tuff lithologies in that core, regardless of their stratigraphic position. Some of those welded tuffs might occur within a formation that has been assigned to the TMA HSU, while other welded tuffs might occur within a formation that is assigned to the TC HSU. Observations regarding various fracture attributes are analyzed relative to both HGUs and HSUs in this study. 


\subsection{Fracture Analysis for Selected Drill Holes}

Several attributes of fractures were analyzed, including vertical distribution of closed and open fractures, distribution relative to fracture orientation, density within the various HGUs and HSUs, aperture and openness within HGUs and HSUs, and fracture-coating minerals within HGUs and HSUs. These fracture attributes are discussed below for each of the drill holes examined. In Section 4.0 of this report, data regarding these attributes are summarized for the entire study area.

In the discussions that follow, two terms are used to quantify the relative abundances of open and closed fractures. The term "fracture distribution" is used to refer to the numbers or relative proportions of open and closed fractures in a certain portion of a given hole. "Fracture density" is defined as the number of observed natural fractures per vertical foot of core. Because the amounts of core footage vary tremendously from drill hole to drill hole, fracture density is considered here to be a more reliable indicator of the degree of fracturing in a certain HGU or HSU. Similarly, different terms are used to subjectively evaluate the attributes that affect the ability of a fracture to transmit water. Two components of relative openness, "aperture" and "percent openness," were estimated for fractures in each sampling interval. "Apertire" is defined as the average width of the void space between fracture surfaces, with the "average" being a visual estimate of the representative width that falls between the minimum and maximum widths measured with a feeler gauge. "Percent openness" is a visual estimate of the percentage of the length of a fracture that is open and was categorized as 0 percent (i.e., closed), 1 - 10 percent, 10 - 50 percent, 50 - 90 percent, 90 - 99 percent, and 100 percent (i.e., completely open). Both components considered together are valuable in estimating the ability of the fracture to transmit water. Aperture and percent openness of open fractures have been analyzed relative to the HGUs and HSUs in which the fractures occur.

Virtually all of the natural fractures quantified in this, study were coated or filled with mineral coatings. The presence of a mineral coating was the primary line of evidence used to differentiate between natural fractures and coring- or handling-induced breaks. In a few isolated instances, natural fractures. were identified without a visible secondary mineral coating. Closed fractures were those completely filled with one or more secondary minerals, whereas open fractures were typically partially to completely "coated" with precipitated minerals, but not completely filled. For the remainder of this report, the term "fracture-coating minerals" will refer to secondary minerals that coat open fractures or fill closed fractures. Secondary fracturecoating minerals observed in this study include zeolites, clays, quartz, chalcedony, calcite, iron 
and manganese oxides, vapor-phase silicate minerals (primarily cristobalite, tridymite, and feldspars), and in some cases, pulverized host rock (fault gouge). Mineral coatings, as identified during fracture examination, are summarized in Table A-1 (Appendix A).

\subsection{Exploratory Hole UE-19x}

\subsubsection{Hole History}

Exploratory Hole UE-19x is located on southeastern Pahute Mesa in the southwestern part of Area 19 of the NTS (Figure 1-1). The hole was drilled in 1977 to obtain subsurface structural information and physical properties data for the BACKBEACH underground nuclear test which was to be conducted in nearby Emplacement Hole U-19x (DOE, 1994). Exploratory Hole UE$19 \mathrm{x}$ was continuously cored from $4.6 \mathrm{~m}(15 \mathrm{ft})$ to its total depth (TD) of $762.9 \mathrm{~m}(2,503 \mathrm{ft})$. Table C-1 (Appendix C) provides a summary of drill hole data for UE-19x.

Exploratory Hole UE-19x was selected for this fracture study because it was continuously cored to TD allowing a comparison of fracture characteristics above and below the water table. All core available, approximately $758.3 \mathrm{~m}(2,488 \mathrm{ft})$, was logged for this study.

\subsubsection{Hydrogeology}

Exploratory Hole UE-19x is located within the Silent Canyon caldera complex. The hole is situated on a north-south-trending structural block bounded on the west by the West Greeley fault and on the east by the Almendro fault. This block is included in the larger Southern Area 19 structural block as defined by Warren (1994).

Exploratory Hole UE-19x penetrated $696.2 \mathrm{~m}$ (2,284 ft) of caldera-burying rocks. These include, from the surface down: $5.3 \mathrm{~m}(18 \mathrm{ft})$ of nonwelded tuff related to the rhyolite of Beatty Wash; $294 \mathrm{~m}$ (965 ft) of ash-flow tuffs related to the Timber Mountain Group; and $396.5 \mathrm{~m}(1,301 \mathrm{ft})$ of rhyolite lavas, ash-flow tuffs, and bedded tuffs related to the Paintbrush Group. The underlying caldera-filling units include $66.8 \mathrm{~m}$ ( $219 \mathrm{ft}$ ) of bedded tuff, nonwelded tuff, and flow breccia related to the Volcanics of Area 20. A condensed stratigraphic and lithologic log for this hole is provided in Table C-2 (Appendix C).

Two HSUs are represented in this stratigraphic sequence, the TMA and the TC. All four HGUs (VTA, WTA, LFA, and TCU) are also well-represented in the core. The static water level is at the depth of approximately $695 \mathrm{~m}(2,280 \mathrm{ft})$. However, a local perched water table was 
encountered at $674.8 \mathrm{~m}(2,214 \mathrm{ft})$ within a zeolitzed pumiceous lava. No hydrologic tests were conducted in this hole.

\subsubsection{Fracture Analysis}

\subsubsection{Density and Distribution}

The density of fractures in the continuous core from Exploratory Hole UE-19x has been analyzed relative to occurrence within various HGUs and HSUs and relative to fracture orientation. In UE-19x, fracture density has also been examined relative to position above or below the water table. In these analyses, the distribution of fractures has been examined separately for open and closed fractures. These relationships are shown in Figures 2-1 and 2-2a-d and discussed below.

\section{Vertical Distribution of Open and Closed Fractures}

Figure 2-1 shows the vertical distribution of all open and closed fractures within the HGUs and HSUs in the UE-19x core. The figure also summarizes the aperture, openness, and density of fractures at high, medium, and low angles, as well as the relationship of fracture distribution to the caliper log.

\section{Density of Open and Closed Fractures in Hydrostratigraphic Units}

The UE-19x corehole penetrated two HSUs: the TMA, and the TC. Fracture density was approximately three times higher in the TC. The density of open fractures exceeded that of closed fractures in both HSUs (Figure 2-2a).

\section{Density of Open and Closed Fractures in Hydrogeologic Units}

Total fracture density is highest in LFA units, followed by WTA units (Figure 2-2b). Most of the variation in fracture density between different HGUs is due to variation in the numbers of open fractures since there is little variation in the density of closed fractures between the different units. No fractures were identified in the VTA.

\section{Density of Open and Closed Fractures Relative to the Water Table}

There is little difference in the density of total fractures above and below the water table in the UE-19x core. However, the density of open fractures is twice that of closed fractures above the water table, whereas below the water table, the density of closed fractures exceeds that of open fractures (Figure 2-2c). 
This page intentionally left blank. 


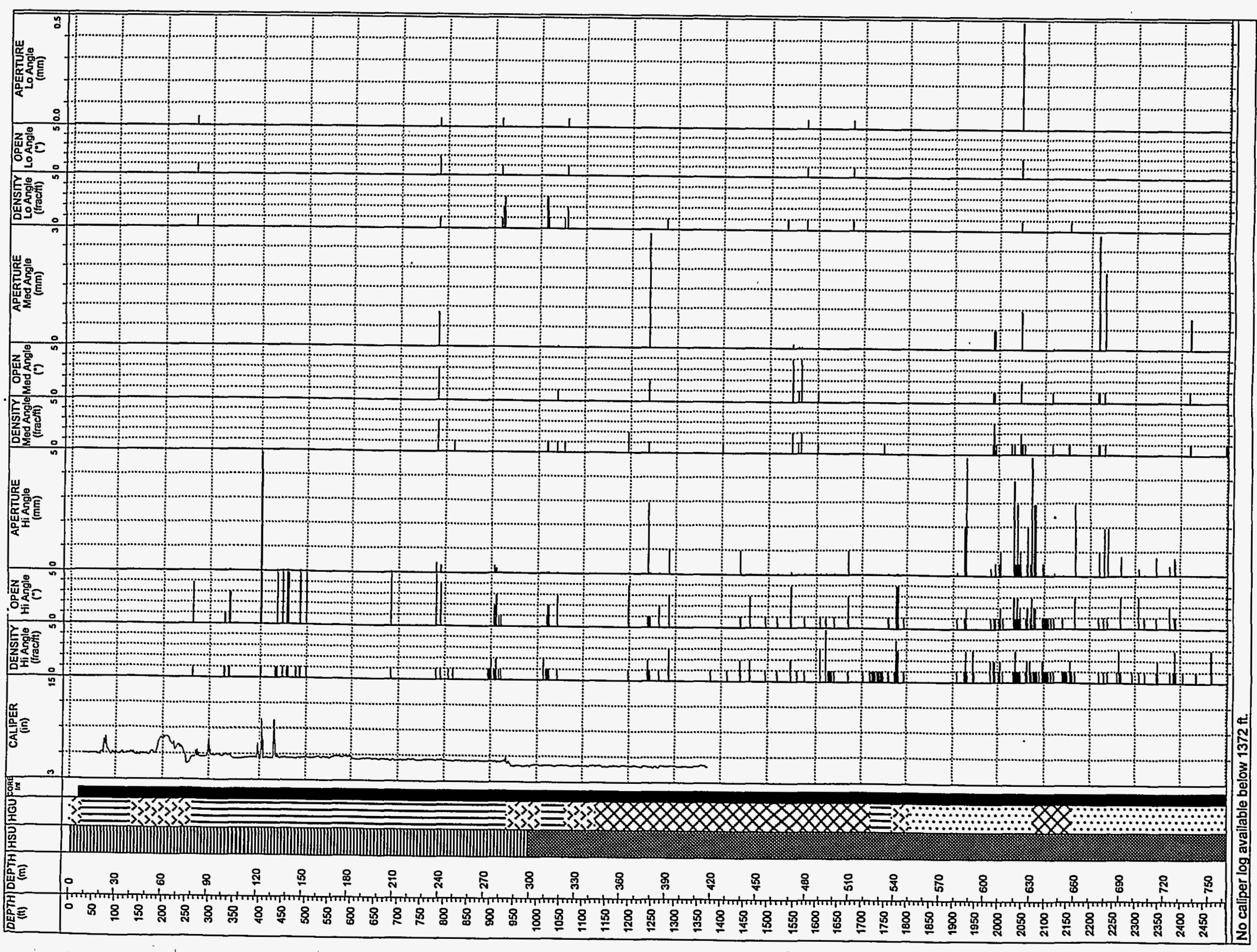




\section{LEGEND}

Hydrostratigraphic Unit (HSU)

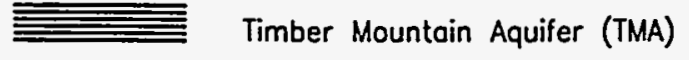

Tuff Cone (TC)

Bullfrog Confining Unit (TCB)

$\$ 8 \%$ Belted Range Aquifer (TBA)

:atiditit: Basal Aquifer (BAO)

Hydrogeologic Unit (HGU)

|I|||||||||||| Welded-tuff aquifer (WTA)

$X X X X X \times$ Lava-flow aquifer (LFA)

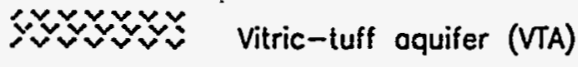

$: \vdots: \vdots: \vdots: \vdots: \vdots$ Tuff confining unit (TCU)

$$
\stackrel{\text { (o) OPEN }}{\text { (for oll ongles) }}
$$

Number

0

1

2

3

4

5
Estimated Range of Percent Openness

$0 \%$

$$
\begin{gathered}
1-10 \% \\
10-50 \% \\
50-90 \% \\
90-99 \% \\
100 \%
\end{gathered}
$$

Figure 2-1

UE-19x: Composite Log of Open and Closed Fracture Data, 4.6 Meters - TD 


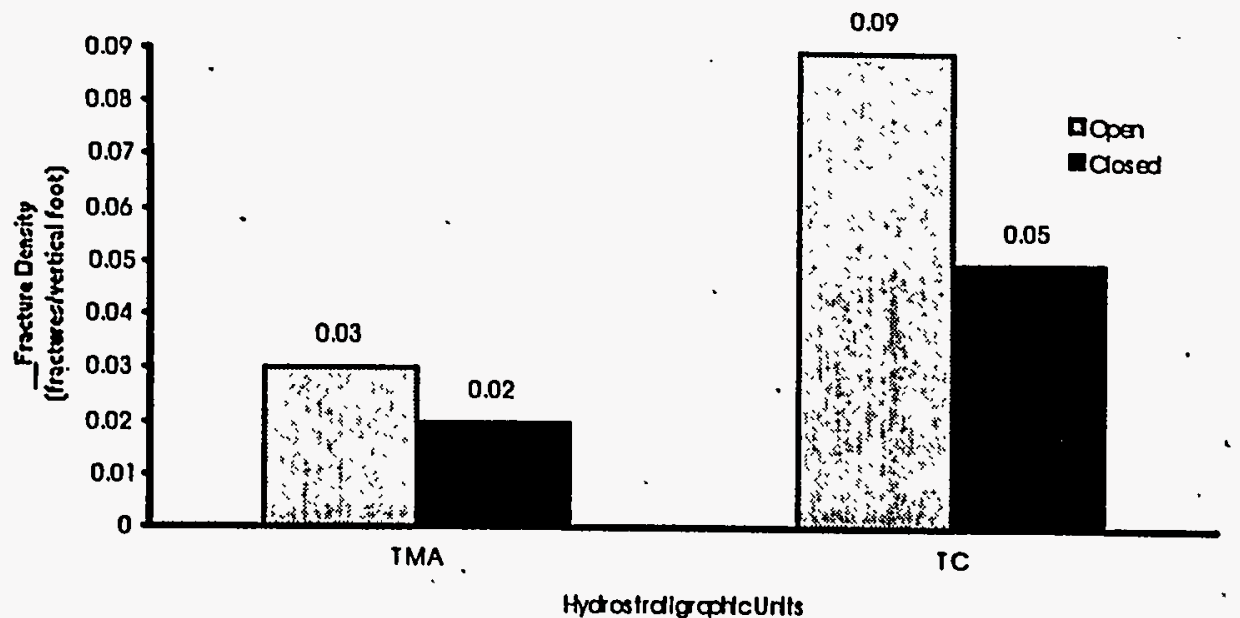

Figure 2-2a

Density of Open and Closed Fractures Relative to Hydrostratlgraphy at UE-19x

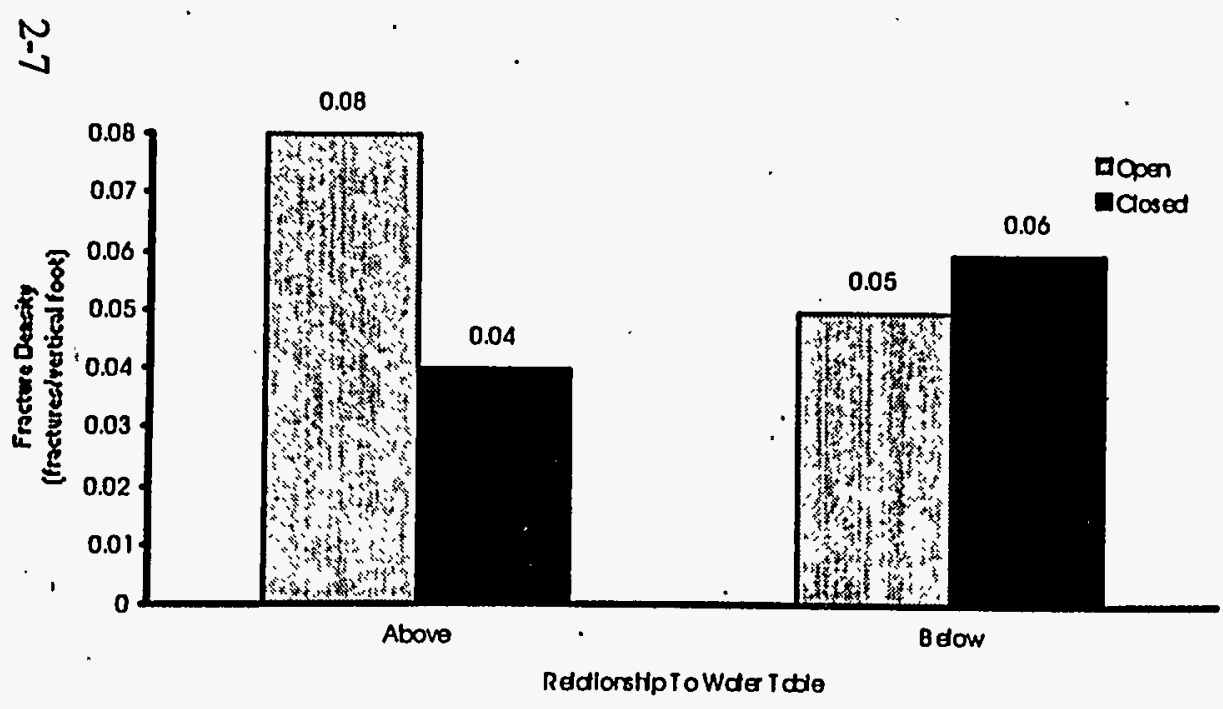

Figure 2-2c

Density of Open and Closed Fractures Relatlve to the Water Table at UE-19x

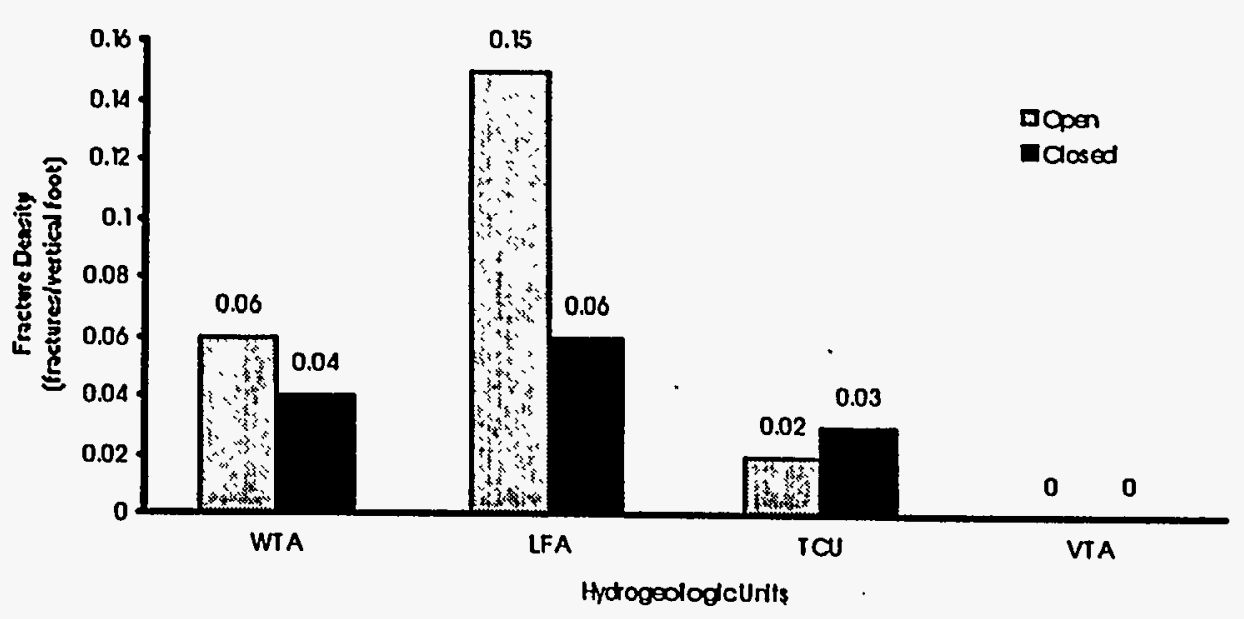

Flgure 2-2b

Denslty of Open and Closed Fractures Relatlve to Hydrogeology at UE-19x

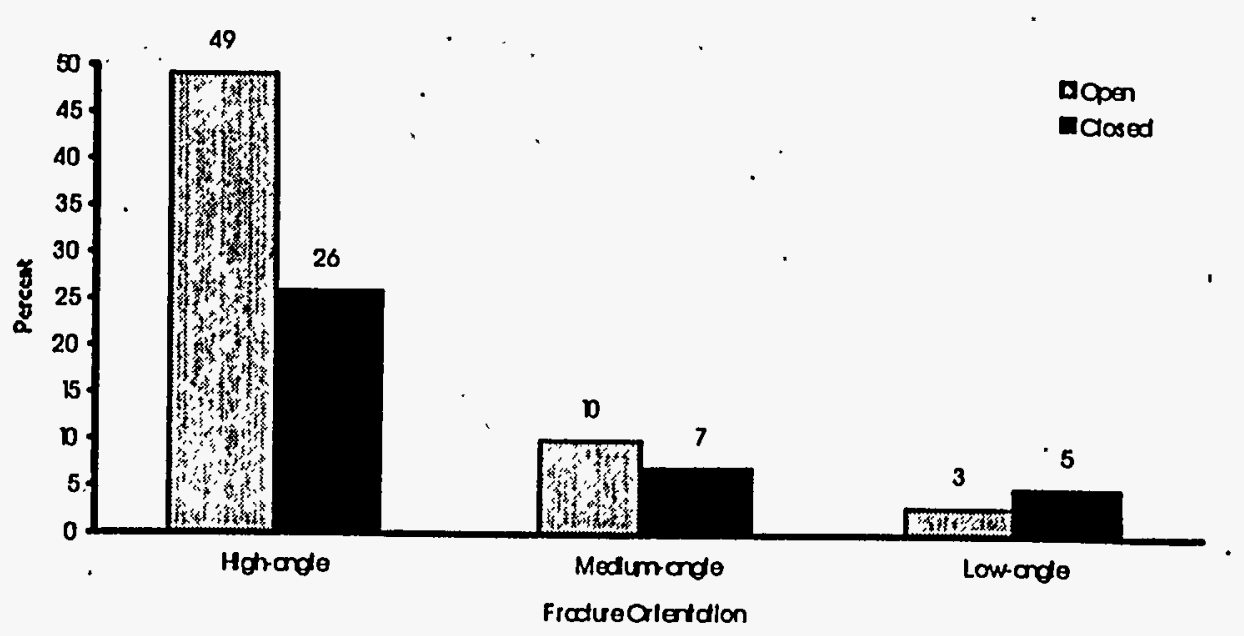

Figure 2-2d

Distribution of Open and Closed Fractures Relative to Orlentation at UE-19x

Figure 2-2a-d

Density and Distribution of Fractures at UE-19x 


\section{Distribution of Open and Closed Fractures Relative to Orientation}

Seventy-five percent of the fractures in the UE-19x core are high-angle. At high-angle and medium-angle orientations, the density of open fractures exceeds that of closed fractures, whereas at low-angle orientations, closed fractures are more abundant (Figure 2-2d).

\subsubsection{Aperture and Fracture Openness}

The aperture and openness relationships observed in the UE-19x core are shown in Table 2-1 and discussed below.

\section{Aperture and Openness Relative to Hydrostratigraphic Units}

Fractures within the TC have an average aperture twice that of fractures within the TMA, however the fractures within the TMA are more open (Table 2-1).

Table 2-1

\section{UE-19x Fracture Aperture and Percent Open Data}

Data Grouped by Hydrostratigraphic Units

\begin{tabular}{||l|c|c|}
\hline \multicolumn{1}{|c|}{ Hydrostratigraphic Units } & $\begin{array}{c}\text { Average Aperture } \\
\text { (millimeters) }\end{array}$ & Percent Open \\
\hline \hline Timber Mountain Aquifer (TMA) & 0.4 & $50-100$ percent \\
\hline Tuff Cone (TC) & 0.8 & $1-50$ percent \\
\hline
\end{tabular}

Data Grouped by Hydrogeologic Units

\begin{tabular}{|l|c|c|}
\hline \multicolumn{1}{|c|}{ Hydrogeologic Unit } & $\begin{array}{c}\text { Aperture } \\
\text { (millimeters) }\end{array}$ & Percent Open \\
\hline \hline Vitric-tuff aquifer (VTA) & $* 1$ & $*$ \\
\hline Welded-tuff aquifer (WTA) & 0.2 & $50-100$ percent \\
\hline Lava-flow aquifer (LFA) & 1.0 & $1-50$ percent $^{2}$ \\
\hline Tuff confining unit (TCU) & 0.6 & $1-50$ percent $^{3}$ \\
\hline
\end{tabular}

1 No open fractures logged.

2 Typical range as presented; however, data set is skewed toward the 10 - 50 percent category.

3 Typical range as presented; however, data set is skewed toward the 1 - 10 percent category. 


\section{Aperture and Openness Relative to Hydrogeologic Units}

The LFA contains fractures with the largest average aperture at $1.0 \mathrm{~mm}(0.04 \mathrm{in}$.), followed by fractures within the TCU at $0.6 \mathrm{~mm}(0.02 \mathrm{in}$ ), and finally by fractures within the WTA at $0.20 \mathrm{~mm}$ (0.008 in.) (Table 2-1). Although the fractures within the WTA have the lowest average aperture, they are the most open, averaging $50-100$ percent open.

\subsubsection{Mineralogy of Fracture Coatings}

\section{Distribution of Fracture-Coating Minerals in Hydrostratigraphic Units}

Figure 2-3a shows the distribution of fracture-coating minerals in the two HSUs represented in the UE-19x core: the TMA and the TC. Overall, zeolites (specifically clinoptilolite/heulandite and mordenite) were the most commonly occurring mineral coating. Chalcedony was the second most abundant fracture-coating mineral in the core. In the TMA, which is positioned primarily above the water table in this well, vapor-phase silicate minerals are the most abundant fracturecoating minerals. Chalcedony, clay, and calcite are also abundant in the TMA with euhedral quartz, zeolites, oxides, and fault gouge present. In the TC, zeolites (clinoptilolite and mordenite) and chalcedony, in that order, are the dominant fracture-coating minerals.

\section{Distribution of Fracture-Coating Minerals in Hydrogeologic Units}

Three HGUs (the WTA, the LFA, and the TCU) were found to contain fractures in the UE-19x core. The distribution of minerals lining or filling fractures varied significantly between the different HGUs as illustrated in Figure 2-3b. In the WTA, a fairly even distribution between several mineral types (zeolites, clays, calcite, chalcedony, and vapor-phase silicate minerals) was observed with quartz, iron and manganese (Fe/Mn) oxides, and fault gouge also observed but in lesser abundances. In the LFA, zeolites and chalcedony were distinctly more abundant as fracture-coating materials than the other mineral types. In the TCU, the same relationship was more pronounced, with zeolites accounting for 60 percent of the occurrences of mineral coatings counted, chalcedony accounting for an additional 31 percent, and clay minerals and oxides representing the remaining 9 percent of the mineral coatings. Euhedral quartz, calcite, vaporphase minerals, and fault gouge were not observed in the TCU.

\section{Distribution of Fracture-Coating Minerals Relative to the Water Table}

In the UE-19x core, zeolites and chalcedony are the predominant mineral fracture coatings both above and below the water table (Figure 2-3c). Below the water table, zeolites and chalcedony 


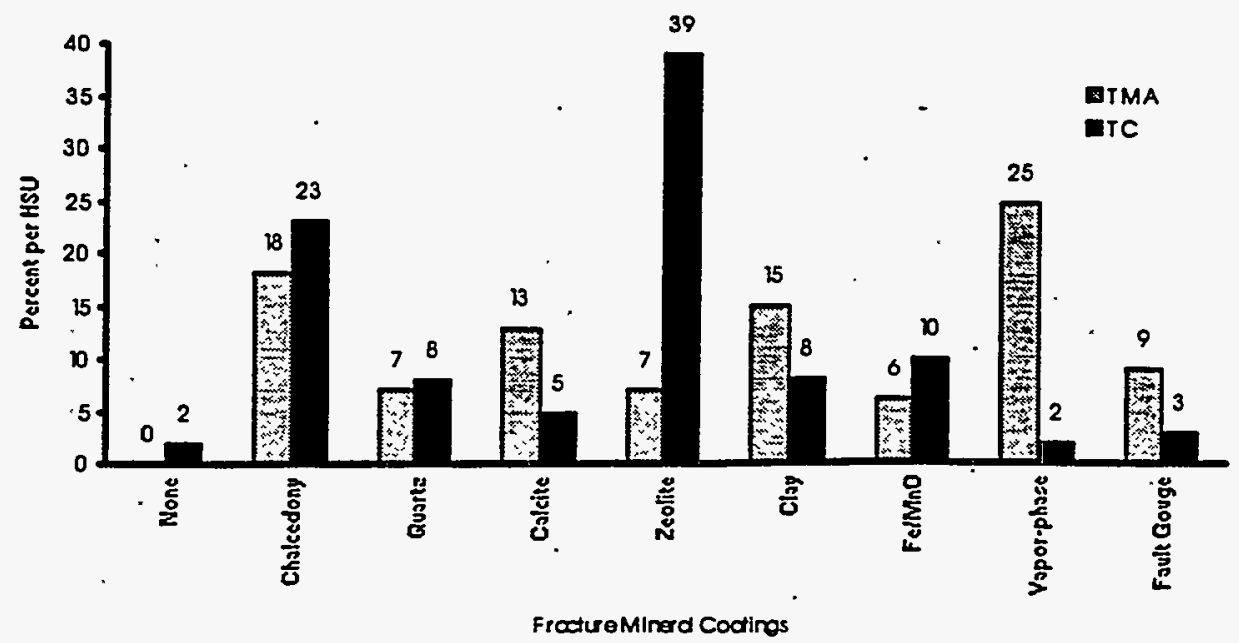

Figure 2-3a

Distribution of Fracture Mineral Coatings Relative to Hydrostratigraphy at UE-19x

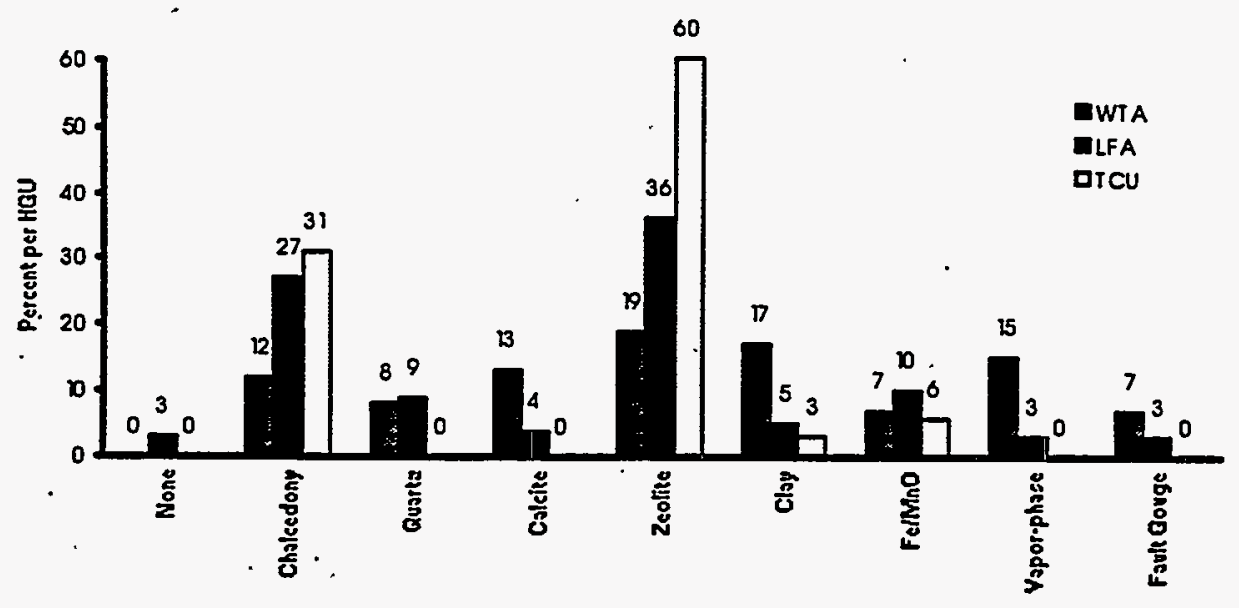

Frocture Minara Coctinos

Figure 2-3b

Dlstribution of Fracture Mineral Coatings Relative to Hydrogeology at UE-19x

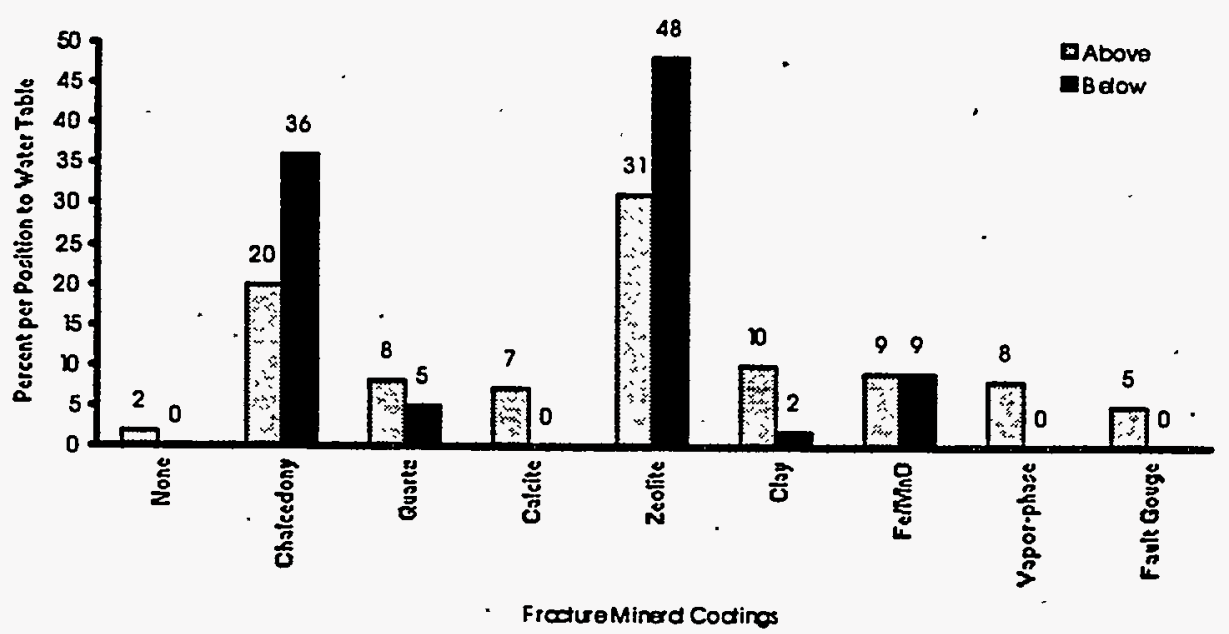

Figure 2-3c

Distribution of Fracture Mineral Coatings Relative to the Water Table at UE-19x

Figure 2-3a-c

Distribution of Fracture-Coating Minerals at Exploratory Hole UE-19x 
are strongly dominant, with other mineral species only rarely observed. Above the water table, the predominance of zeolite and chalcedony is less pronounced, and minerals such as clay minerals, Fe/Mn oxides, euhedral quartz; calcite, and vapor-phase silicates (combined) account for a significant portion (42 percent) of the mineral coatings observed. Calcite, vapor-phase silicates, and fault-gouge coatings were observed only above the water table.

\subsection{Exploratory Hole UE-18t}

\subsubsection{Hole History}

Exploratory hole UE-18t is located immediately southeast of Pahute Mesa in the northeastern part of the Timber Mountain caldera moat in Area 18 of the Nevada Test Site (Figure 1-1). The hole was drilled in 1978 to evaluate the suitability of the Timber Mountain moat area for underground nuclear tests (Byers et al., 1981). UE-18t was continuously cored from $36.6 \mathrm{~m}$ $(120.1 \mathrm{ft})$. to its total depth of $792.5 \mathrm{~m}(2,600 \mathrm{ft})$. Drill hole statistics for this hole are summarized in Table C-3 in Appendix C. A more thorough account of the UE-18t drill hole is provided in Byers et al. (1981).

Exploratory Hole UE-18t was selected for this fracture study because it provides a significant interval of continuous core below the static water level. Also, and of equal importance, its location affords the possibility to yield significant hydrogeologic information about the Timber Mountain caldera and its influence upon the groundwater flow at the NTS.

\subsubsection{Hydrogeology}

The Timber Mountain caldera complex consists of two nested calderas formed by the collapse of pre-Rainier Mesa rocks over a magma chamber following eruptions of two major ash-flow tuff units: the older Rainier Mesa Tuff (which formed the larger Rainier Mesa caldera) and the younger Ammonia Tanks Tuff (which resulted in the smaller Ammonia Tanks caldera).

The Timber Mountain caldera moat is a structural and geomorphic feature defined by the outermost caldera wall and the Timber Mountain resurgent dome. Drill hole UE-18t is located in the northeastern moat area within the northeastern Timber Mountain Bench structural block as defined by Warren (1994). Additionally, geophysical data (aeromagnetic and gravity) and lithologic details from UE-18t indicate that this site lies within the outer collapse zone of the (larger) Rainier Mesa caldera (Warren, 1994; Byers et al., 1981). 


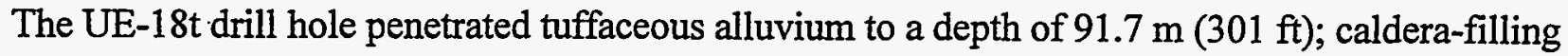
ash-flow and bedded tuffs related to the Thirsty Canyon Group, Volcanics of Fourtymile Canyon, and the Ammonia Tanks Tuff to a depth of $498.4 \mathrm{~m}(1,635 \mathrm{ft})$; and reached total depth within an intracaldera facies of the Rainier Mesa Tuff. A condensed stratigraphic and lithologic log for drill hole UE-18t is provided in Table C-4 in Appendix C.

Based on the above stratigraphy, the volcanic rocks encountered at UE-18t are assigned to the TMA. Initially, the two dominant lithologies, welded ash-flow tuffs and nonwelded/bedded tuffs, can be subdivided hydrogeologically into VTA and WTA, respectively. However, proximity of this site to the caldera ring fracture zone has resulted in sporadic hydrothermal alteration. In the more porous rocks, massive clay alteration is common, mostly to montmorillonite, with minor illite and lesser kaolinite. For the welded ash-flow tuffs, discrete argillized zones and/or clay and calcite filled fractures are common. Such alteration has significant hydrologic ramifications. See the following subsections and Section 4.0 for additional details and discussion.

The static water level at UE-18t is reported at depth of $278.9 \mathrm{~m}$ (915 ft) (Reiner et al., 1995). No hydrologic tests were conducted in the borehole.

\subsubsection{Fracture Analysis}

\subsubsection{Density and Distribution}

Examination of fractures in this core was limited to those that occur below the water table. The density of fractures within the TMA has been analyzed relative to occurrence within various HGUs and relative to fracture orientation. In these analyses, the distribution of fractures has been examined separately for open and closed fractures. These relationships are shown in Figures 2-4 and 2-5a-c and discussed in the following text.

\section{Vertical Distribution of Fractures}

Figure 2-4 shows the vertical distribution of open fractures in the HGUs in the UE-18t core. The figure also presents data on the aperture, openness, and density of fractures at high, medium, and . low angles as well as the relationship of fracture distribution to the caliper log. 


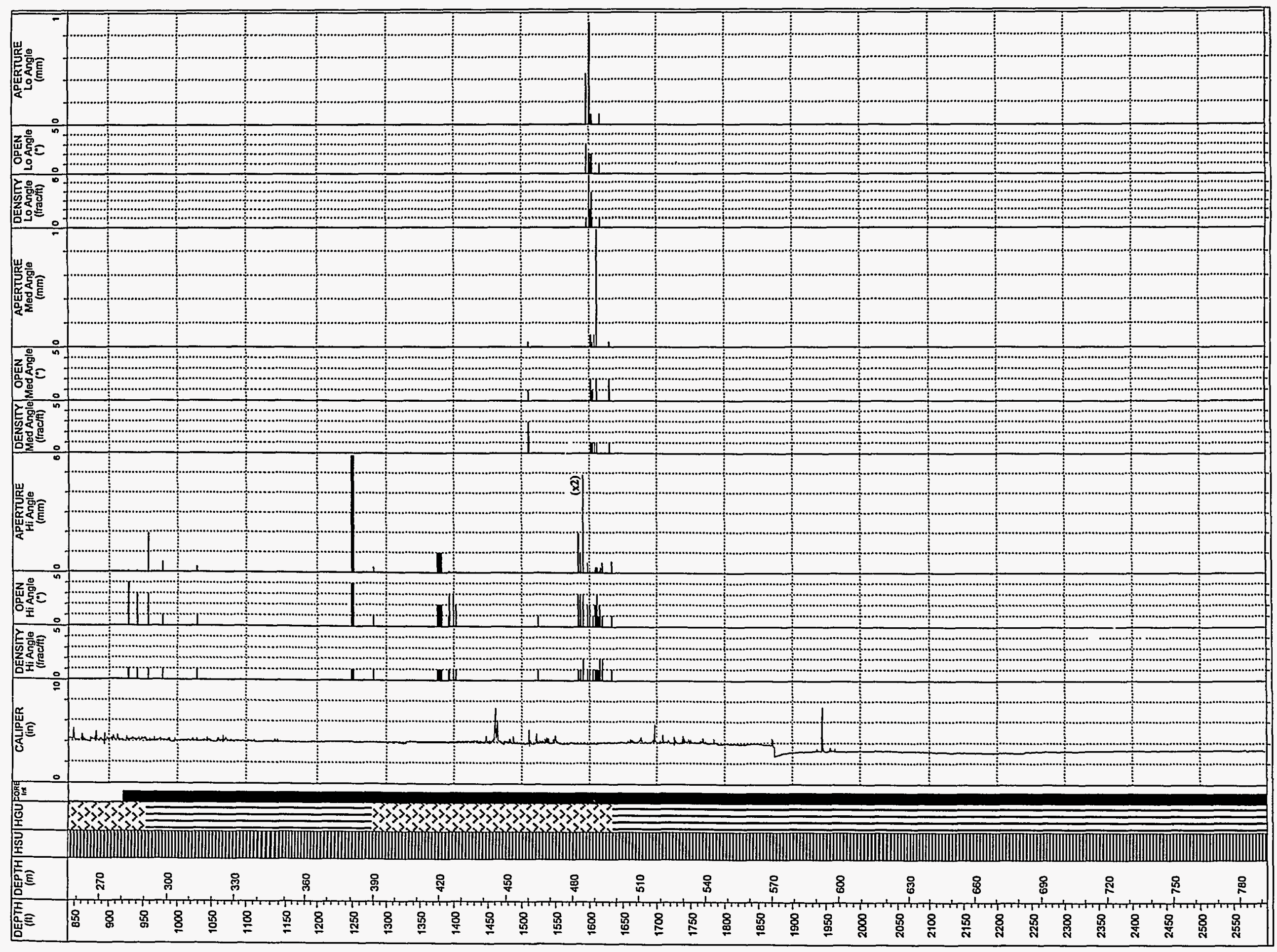


LEGEND

Hydrostratigrophic Unit (HSU)

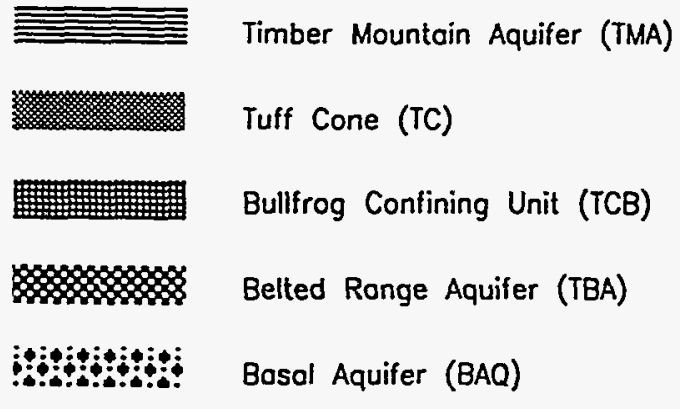

Hydrogeologic Unit (HGU)

IIIIIHIIII Welded-tuff oquifer (WTA)

$\times \times \times \times \times \times$ Lava-flow oquifer (LFA)

Vitric-tuff oquifer (VTA)

$\vdots: \vdots: \vdots:: \vdots: \vdots$ Tuff confining unit (TCU)

$$
\begin{aligned}
& \text { (o) QPEN } \\
& \text { (for all angles) }
\end{aligned}
$$

\begin{tabular}{cc} 
Number & Estimated Ronge of Percent Openness \\
\hline 0 & $0 \%$ \\
1 & $1-10 \%$ \\
2 & $10-50 \%$ \\
3 & $50-90 \%$ \\
4 & $90-99 \%$ \\
5 & $100 \%$
\end{tabular}

Figure 2-4

UE-18: Composite Log of Open Fracture Data, 256 Meters - TD 


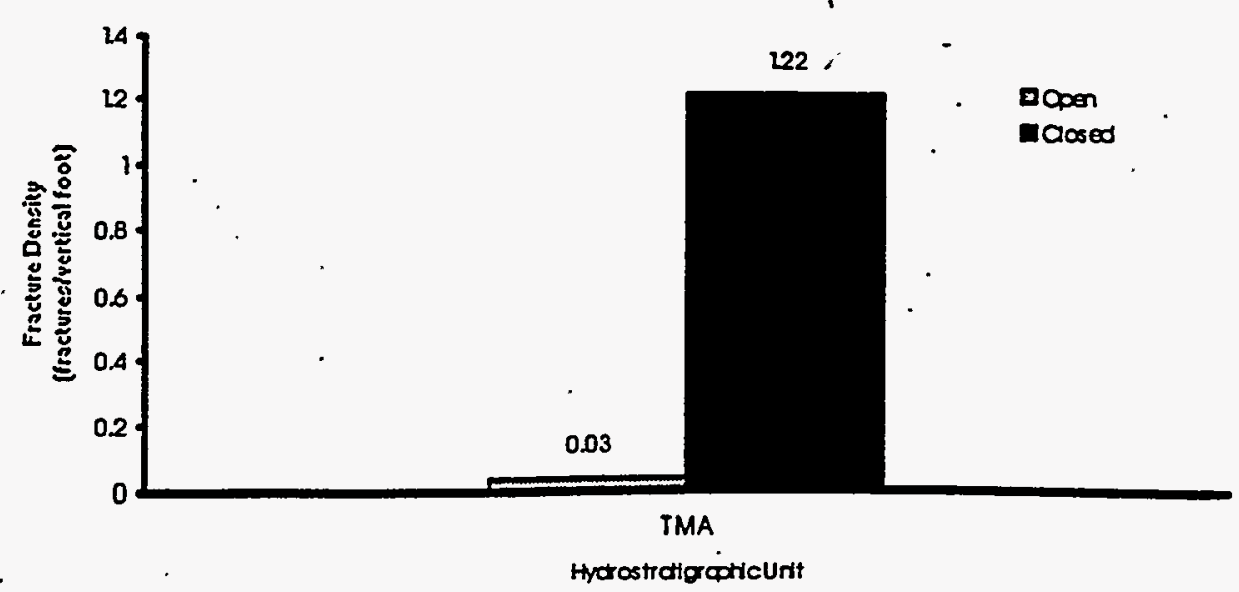

Figure 2-5a

Density of Open and Closed Fractures Relative to Hydrostratigraphy at UE-18t

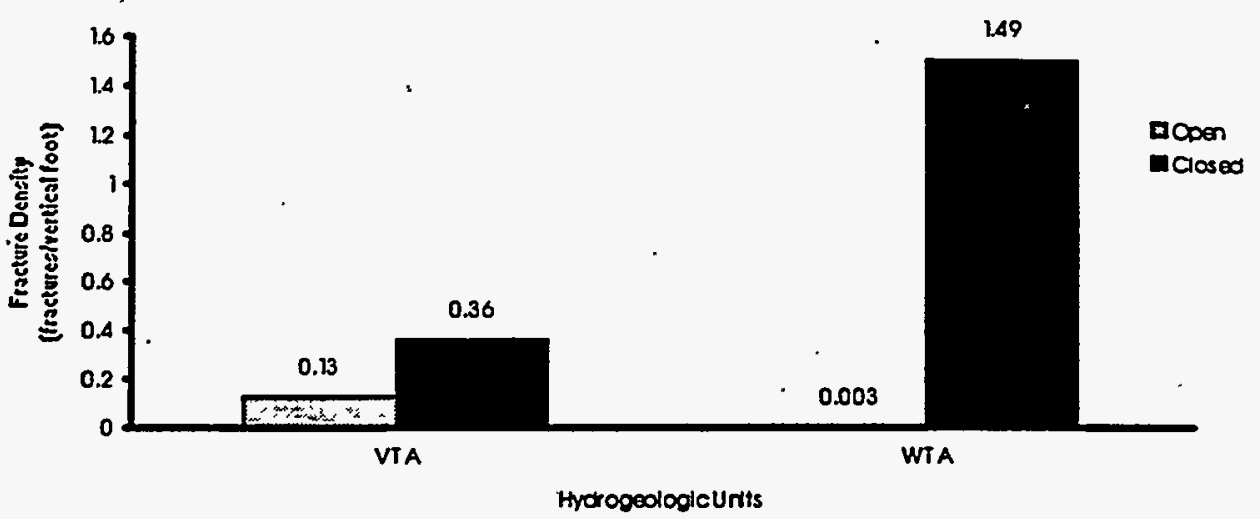

Figure 2-5b

Density of Open and Closed Fractures Relatlve to Hydrogeology at UE-18t

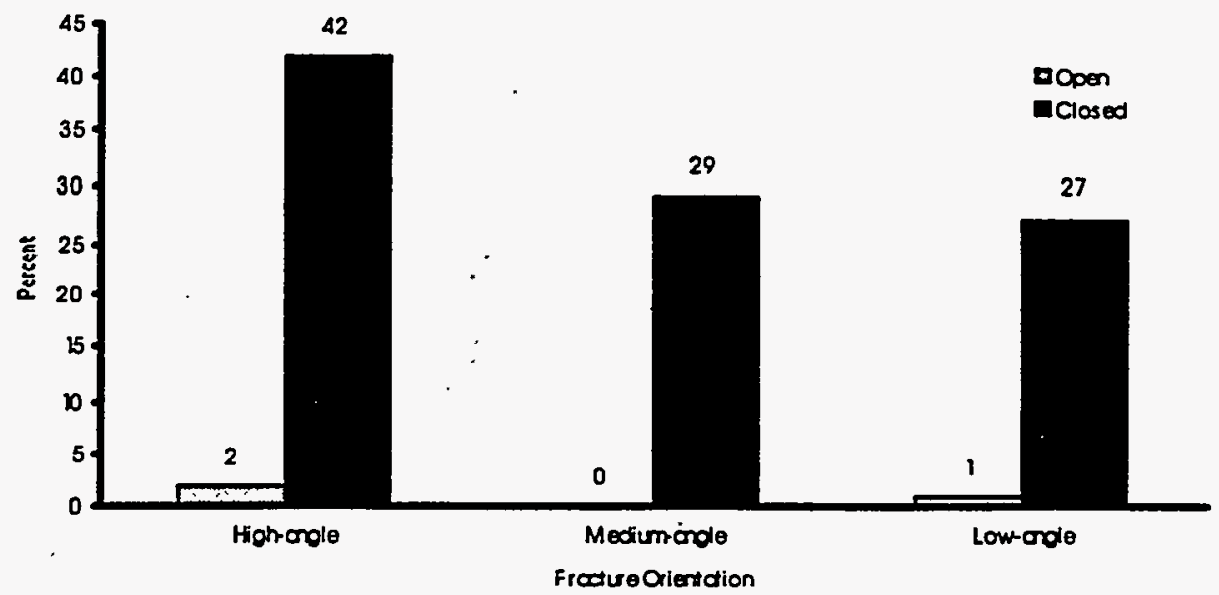

Figure 2-5c

Distribution of Open and Closed Fractures Relative to Orlentation at UE-18t

Figure 2-5a-c

Density and Distribution of Fractures at Exploratory Hole UE-18t 


\section{Density of Open and Closed Fractures in Hydrostratigraphic Units}

The UE-18t corehole penetrated only one HSU, the TMA. In this core, the density of closed fractures greatly exceeds that of open fractures (Figure 2-5a). A total of 2,108 fractures were counted in the core, 2,051 of which ( 97 percent) were closed, and only 57 (three percent) were open.

\section{Density of Open and Closed Fractures in Hydrogeologic Units}

The WTA has a higher fracture density than the VTA; however, essentially all the fractures observed in the WTA are closed (Figure 2-5b). The density of closed fractures is twice that for open fractures within the VTA.

\section{Distribution of Open and Closed Fractures Relative to Orientation}

In UE-18t, fractures oriented at high angles are more abundant than medium- and low-angle fractures. Sixty-six percent of the open fractures are high-angle, while 43 percent of the closed fractures are high-angle (Figure 2-5c).

\subsubsection{Aperture and Fracture Openness}

Aperture and percent openness of open fractures in the UE-18t core have been analyzed relative to the HGUs and the HSUs in which the fractures occur. These relationships are shown in Täble 2-2 and outlined below.

\section{Aperture and Openness Relative to Hydrostratigraphic Units}

At UE-18t the TMA contains fractures that have an average aperture of $0.8 \mathrm{~mm}(0.03 \mathrm{in}$.) and are 10 - 50 percent open (Table 2-2).

\section{Aperture and Openness Relative to Hydrogeologic Units}

Fractures within the WTA have a relatively large average aperture of $2.2 \mathrm{~mm}(0.09 \mathrm{in}$.) which is over twice that of fractures within the VTA, which have an average aperture of $1.0 \mathrm{~mm}(.04 \mathrm{in}$.) (Table 2-2). However, the fractures within the VTA have a higher average percent open.

\subsubsection{Mineralogy of Fracture Coatings}

\section{Distribution of Fracture-Coating Minerals in Hydrostratigraphic Units}

The distribution of fracture-coating minerals in the UE-18t core, all of which is assigned to the TMA, is presented in Figure 2-6a. Clay minerals are the most abundant fracture-coating or -filling mineral in the core, followed by calcite, and iron and manganese oxides. Occurrences of 
Table 2-2

UE-18t Fracture Aperture and Percent Open Data

Data Grouped by Hydrostratigraphic Units

\begin{tabular}{|c|c|c|}
\hline Hydrogeologic Unit & $\begin{array}{c}\text { Average Aperture } \\
\text { (millimeters) }\end{array}$ & Percent Open \\
\hline Timber Mountain Aquifer (TMA) & 0.8 & $10-50$ percent \\
\hline
\end{tabular}

Data Grouped by Hydrogeologic Units

\begin{tabular}{||l|c|c|}
\hline \multicolumn{1}{|c|}{ Hydrogeologic Unit } & $\begin{array}{c}\text { Average Aperture } \\
\text { (millimeters) }\end{array}$ & Percent Open \\
\hline \hline Vitric-tuff aquifer (VTA) & 1.0 & $10-50$ percent \\
\hline Welded-tuff aquifer (WTA) & 2.2 & $1-10$ percent \\
\hline
\end{tabular}

chalcedony, quartz, and zeolites are conspicuously low in core from UE-18t compared to the cores from other holes examined in this study.

\section{Distribution of Fracture-Coating Minerals in Hydrogeologic Units}

Because the majority of total fractures in the UE-18t core occur in the WTA, the relationships mentioned previously regarding the distribution of fracture-filling minerals in the TMA also apply to the WTA. Clay minerals, calcite, and iron and manganese oxides are the most commonly observed mineral fillings in fractures in the WTA (Figure 2-6b). The distribution of fracture-filling minerals in the VTA, however, is markedly different from that in the WTA. In the VTA, zeolites are the significant fracture-filling material, followed by clay minerals, $\mathrm{Fe} / \mathrm{Mn}$ oxides, and quartz are also relatively abundant. Clay minerals and calcite are significantly less common in the VTA than in the WTA.

\subsection{Exploratory Hole UE-18r}

\subsubsection{Hole History}

Exploratory hole UE-18r is located in northwestern Area 18 near the western boundary of the NTS. This location is within the northern part of the Timber Mountain caldera moat south of Pahute Mesa (Figure 1-1). UE-18r, drilled in late 1967 and early 1968, was the first deep exploratory hole in the Timber Mountain caldera. Its purpose was to obtain stratigraphic, structural, and hydrologic information for this part of the caldera and to evaluate the area for 


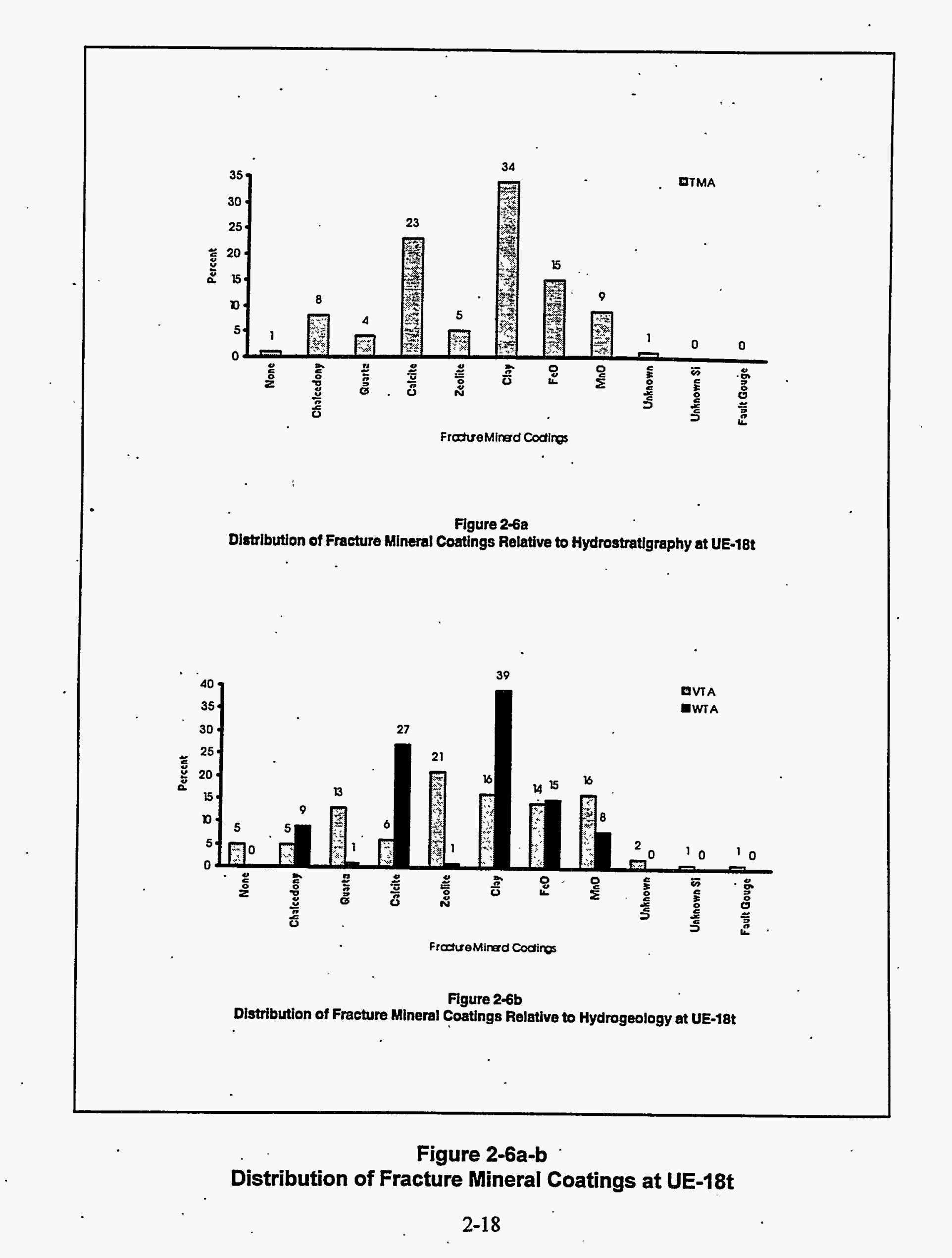


underground nuclear testing (Carr et al., 1968, 1981). The borehole was rotary drilled to a total depth of $1,525.2 \mathrm{~m}(5,004 \mathrm{ft})$. Fifteen cores were taken at various depths during drilling. A summary of drill hole statistics is provided in Table $\mathrm{C}-5$ in Appendix $\mathrm{C}$, and coring data is given in Table C-6 in Appendix C.

Exploratory Hole UE-18r was selected for this study because of the availability of a televiewer log with intermittent core and because of its hydrogeologically important location within the Timber Mountain caldera. All available core from this hole, approximately $35.7 \mathrm{~m} \mathrm{(117} \mathrm{ft),} \mathrm{was}$ logged for this fracture study.

\subsubsection{Hydrogeology}

Exploratory Hole UE-18r is located within the Northern Timber Mountain Moat structural block (Warren, 1994). Intracaldera facies of the Ammonia Tanks Tuff and the Rainier Mesa Tuff were penetrated, suggesting this location lies within both the Ammonia Tanks and the Rainier Mesa calderas (Warren, 1994). Major units penetrated by the borehole include: $324.6 \mathrm{~m}(1,065 \mathrm{ft})$ of welded ash-flow tuffs related to the Thirsty Canyon Group and Volcanics of Forty Mile Canyon; $860 \mathrm{~m}(2,821 \mathrm{ft})$ of intracaldera welded ash-flow tuff and lava related to the Ammonia Tanks Tuff and rhyolite of Tannenbaum Hill, respectively; and $74.7 \mathrm{~m}$ ( $245.1 \mathrm{ft}$ ) of intracaldera welded ash-flow tuff sandwiched between two fairly thick (182.5 and $>83.5 \mathrm{~m}$ ), landslide or eruptive breccia deposits all related to the Rainier Mesa Tuff. The debris flows and breccias result from the erosion and collapse of the caldera walls. They are a mixture of dense, hard rhyolite lava and welded tuff blocks derived from the caldera wall in a matrix of soft nonwelded tuff. At UE-18r, these debris flows intertongue with the Rainier Mesa ash-flow tuff. A condensed stratigraphic and lithologic $\log$ for Exploratory Hole UE-18r is provided in Table C-7 in Appendix C.

The volcanic units previously described are categorized hydrostratigraphically as the TMA. This sequence can be further subdivided into the four hydrogeologic units based on lithology and alteration (Figure 2-7). The static water.level at UE-18r is reported at $416 \mathrm{~m}(1,365 \mathrm{ft})$ depth (Reiner et al., 1995). Aquifer tests were conducted in 1968 and are summarized in Blankennagel and Weir (1973) and Carr et al. $(1968,1981)$. FMS and.flow logs were run in recent years as part of a recompletion effort for the UGTA program. The results of hydrologic tests are presented in Section 2.3.4. 
This page intentionally left blank. 


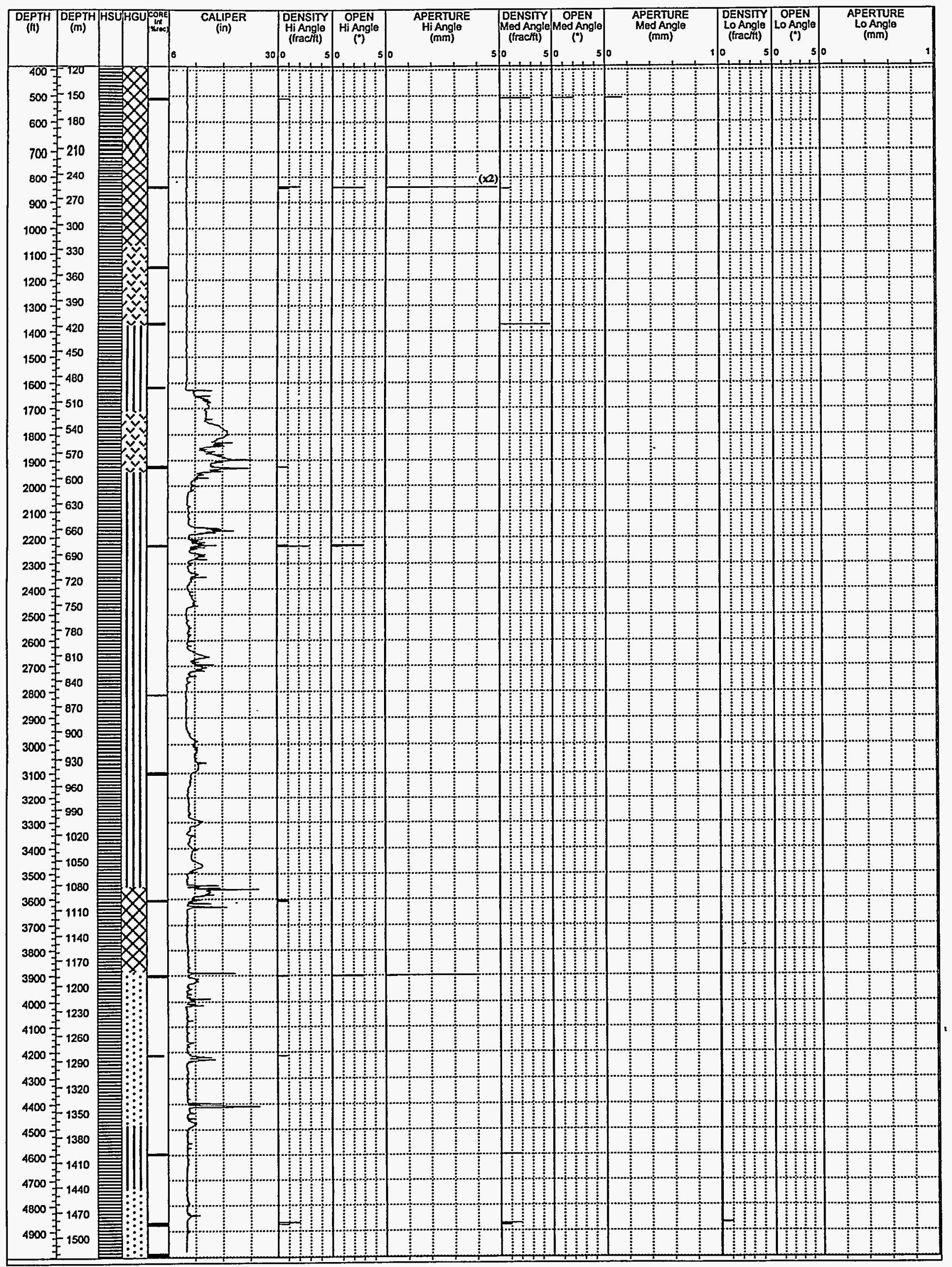




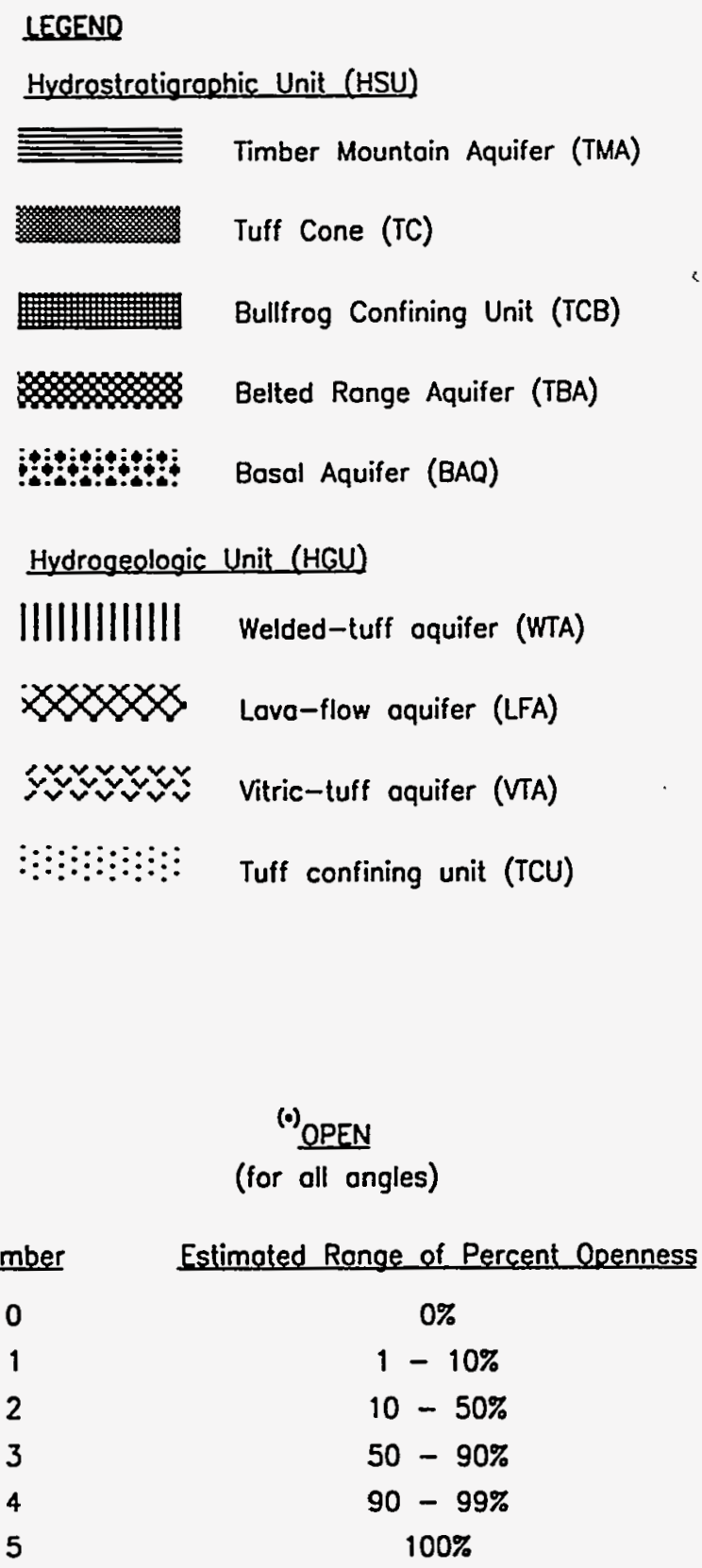

Figure 2-7 


\subsubsection{Fracture Analysis}

\subsubsection{Density and Distribution}

The density of fractures in the core sections from UE-18 $\mathrm{r}$ has been analyzed relative to occurrence within the TMA HSU, various HGUs, and relative to fracture orientation. In these analyses, the distribution of fractures has been examined separately for open and closed fractures. These relationships are shown in Figure 2-7 and Figure 2-8a-d and discussed below.

\section{Vertical Distribution of Open and Closed Fractures}

Figure 2-7 shows the core intervals examined and the vertical distribution of open and closed fractures within the TMA in the UE-18r core. The figure also presents data on the aperture, openness, and density of fractures at high, medium, and low angles. The figure also shows the relationship of fracture distribution to the caliper log.

\section{Density of Open and Closed Fractures in Hydrostratigraphic Units}

The cored intervals in Exploratory Hole UE-18r represent strata that have been assigned to the TMA. The density of closed fractures in the TMA is twice that of open fractures (Figure 2-8a). Sixty-seven percent of the fractures examined in the core sections are closed, while 33 percent are open.

\section{Density of Open and Closed Fractures in Hydrogeologic Units}

Four HGUs (the LFA, the VTA, the WTA, and the TCU) are represented in the UE-18r core. In the WTA, the density of open fractures exceeds that of closed fractures, whereas in the other HGUs, closed fractures outnumber the open fractures (Figure 2-8b).

\section{Density of Open and Closed Fractures Relative to the Water Table}

The density of closed fractures exceeds that for open fractures both above and below the water table at UE-18r (Figure 2-8c). Closed fractures are only slightly more abundant than open fractures above the water table, whereas below the water table, closed fractures are more than twice as abundant than open fractures. The density of closed fractures is approximately equal above and below the water table. In contrast, the density of open fractures above the water table is over twice the density of open fractures below the water table. 


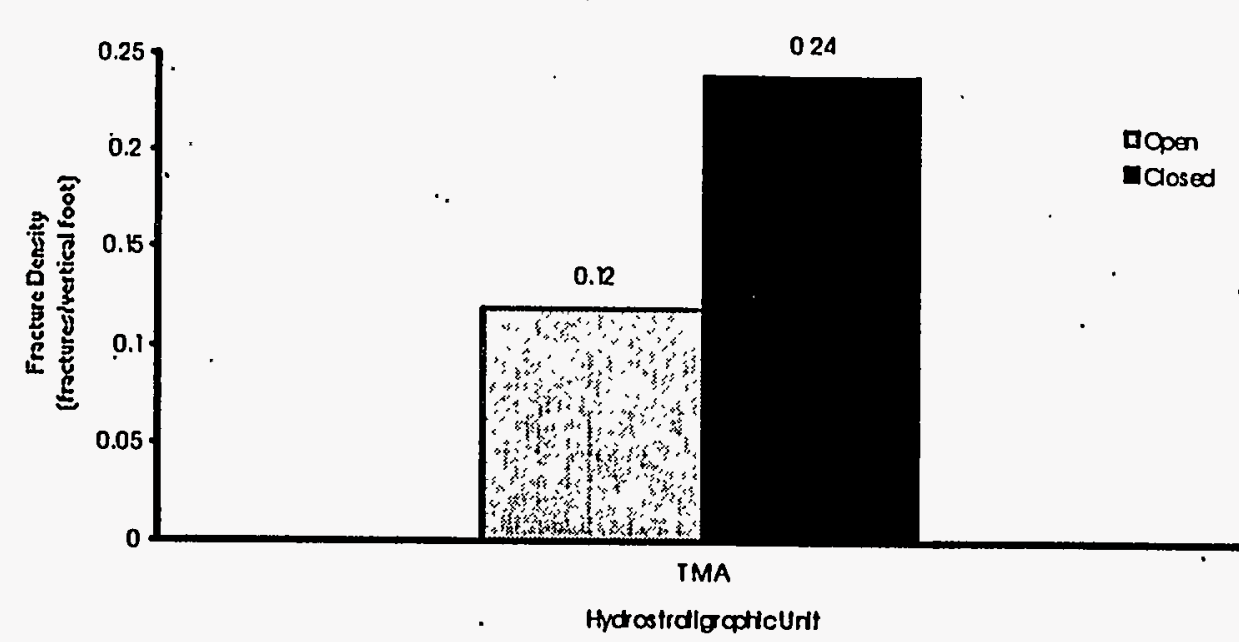

Figure 2-8a

Density of Open and Closed Fractures Pelative to Hydrostratlgraphy at UE-18r

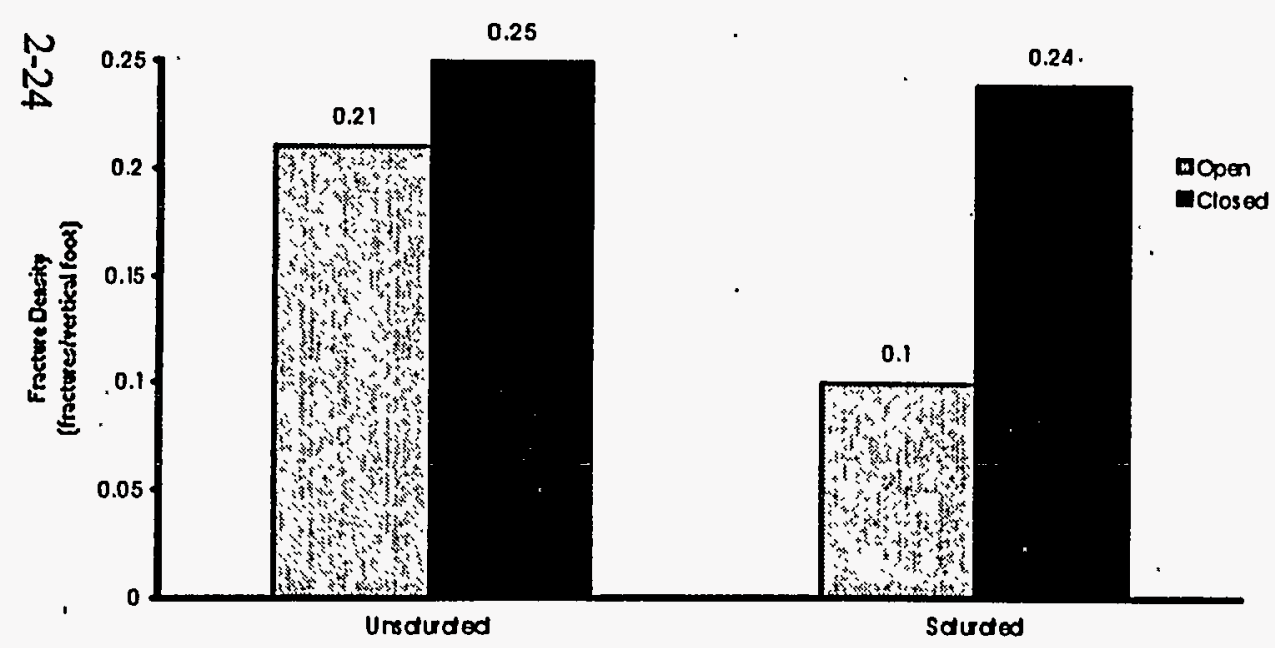

Figure 2-8c

Density of Open and Closed Fractures Relatlve to the Water Table at UE-18r

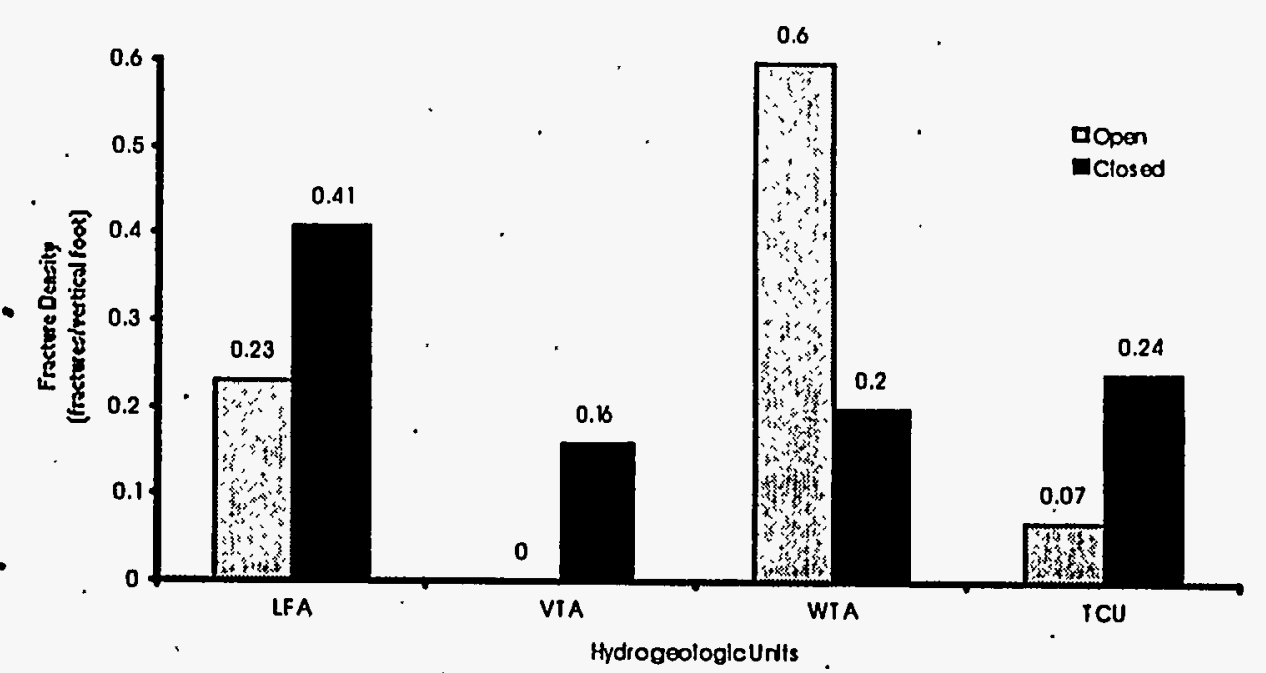

Figure 2-8b

Density of Open and Closed Fractures Relatlve to Hydrogeology at UE-18r

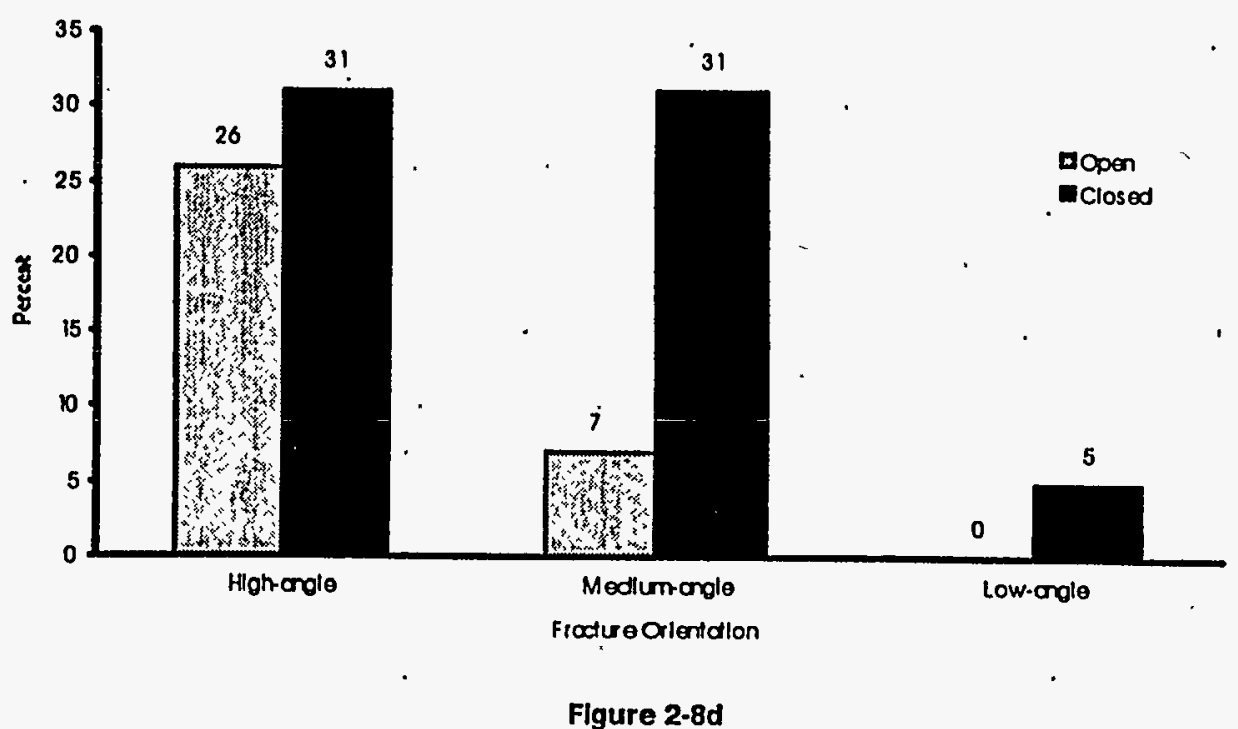

DIstrlbutlon of Open and Closed Fractures Relatlve to Orlentatlon at UE-18r

Figure 2-8a-d

Density and Distribution of Fractures at Exploratory Hole UE-18r 


\section{Distribution of Open and Closed Fractures Relative to Orientation}

In UE-18r, 79 percent of the open fractures are at high angles, and the remainder of open

fractures are medium-angle; no low-angle open fractures were observed. The closed fractures are evenly distributed between high- and medium-angle orientations, with only two low-angle closed fractures observed (Figure 2-8d).

\subsubsection{Aperture and Fracture Openness}

Aperture and percent openness of open fractures in the UE-18r core have been analyzed relative to the HGUs and the HSU in which the fractures occur. These relationships are shown in

Table 2-3 and outlined below.

Table 2-3

UE-18r Fracture Aperture and Percent Open Data

Data Grouped by Hydrostratigraphic Units

\begin{tabular}{||l|c|c|}
\hline Hydrostratigraphic Units & $\begin{array}{c}\text { Average Aperture } \\
\text { (millimeters) }\end{array}$ & Percent Open \\
\hline \hline Timber Mountain Aquifer (TMA) & 1.1 & $50-90$ percent $^{1}$ \\
\hline
\end{tabular}

Data Grouped by Hydrogeologic Units

\begin{tabular}{||l|c|c|}
\hline \multicolumn{1}{|c|}{ Hydrogeologic Unit } & $\begin{array}{c}\text { Average Aperture } \\
\text { (millimeters) }\end{array}$ & Percent Open \\
\hline \hline Vitric-tuff aquifer (VTA) & $\star^{2}$ & $\star^{2}$ \\
\hline Welded-tuff aquifer (WTA) & 0.04 & $1-10$ and $50-90$ percent $^{3}$ \\
\hline Lava-flow aquifer (LFA) & $2.1^{4}$ & $50-90$ percent \\
\hline Tuff confining unit (TCU) & 1.5 & $50-90$ and $1-10$ percent \\
\hline
\end{tabular}

1 Percent open data collected is bimodal. The most popular group is $50-90$ percent as shown; however, a lesser group of fractures fell into the $1: 10$ percent open category.

$211.9 \mathrm{~m}$ (39.ft) of VTA core logged, but no open fractures observed.

3 Percent open data collected is bimodal; 66 percent of the fractures fell into the 1 - 10 percent open category, while 33 percent fell into the $50-90$ percent category.

4 Average aperture is skewed by a single, $10 \mathrm{~mm}$ wide fracture in this relatively small data set $(\mathrm{N}=5)$.

5 Percent open data collected is bimodal; 66 percent of the fractures fell into the $50-90$ percent category and 33 percent fell into the 1 - 10 percent category. 


\section{Aperture and Openness Relative to Hydrostratigraphic Units}

The average aperture for fractures within the TMA is relatively large at $1.1 \mathrm{~mm}(0.04 \mathrm{in}$.)

(Table 2-3). The average percent open for the fractures is $50-90$ percent.

\section{Aperture and Openness Relative to Hydrogeologic Units}

Both the LFA and TCU contain fractures with relatively large average apertures of $2.1 \mathrm{~mm}$ (0.08 in.) and $1.5 \mathrm{~mm}(0.06 \mathrm{in}$ ), respectively. In contrast, fractures within the WTA have a very small average aperture of $0.04 \mathrm{~mm}(0.002 \mathrm{in}$.). Most of the fractures within the LFA and TCU average greater than 50 percent open, whereas most of the fractures within the WTA average less than 10 percent open:

\subsubsection{Mineralogy of Fracture Coatings}

The distribution of fracture-coating minerals in core from UE-18r is illustrated by hydrostratigraphic unit, hydrogeologic unit, and relative to the water table in Figure 2-9a-c.

\section{Distribution of Fracture-Coating Minerals in Hydrostratigraphic Units}

The distribution of fracture-coating minerals in the UE-18r core, all of which is assigned to the TMA, is presented in Figure 2-9a. Zeolites (clinoptilolite and mordenite) are the most abundant fracture-coating or -filling minerals in the core, followed by iron/manganese oxides and chalcedony.

\section{Distribution of Fracture-Coating Minerals in Hydrogeologic Units}

Marked variation exists in the distribution of fracture-coating minerals between the four HGUs represented in the UE-18r core sections. The following relationships are shown in Figure 2-9b:

LFA - dominant zeolites, common chalcedony, minor clay, unknown silicates, and Fe/Mn oxides

VTA - 'even distribution between zeolites Fe/Mn oxides, and fault gouge

WTA - common chalcedony and Fe/Mn oxides; all others absent

TCU - strongly dominant zeolites, minor quartz Fe/Mn oxides, and clay

Zeolites are the predominant fracture-coating mineral in the TCU and the LFA and very common in the VTA, but not observed in the WTA. Conversely, Fe/Mn oxides are very common in the WTA, but not observed at all in the other HGUs. Chalcedony is common in the WTA and the LFA, but not present in the VTA or TCU. Euhedral quartz is observed only in the TCU. 


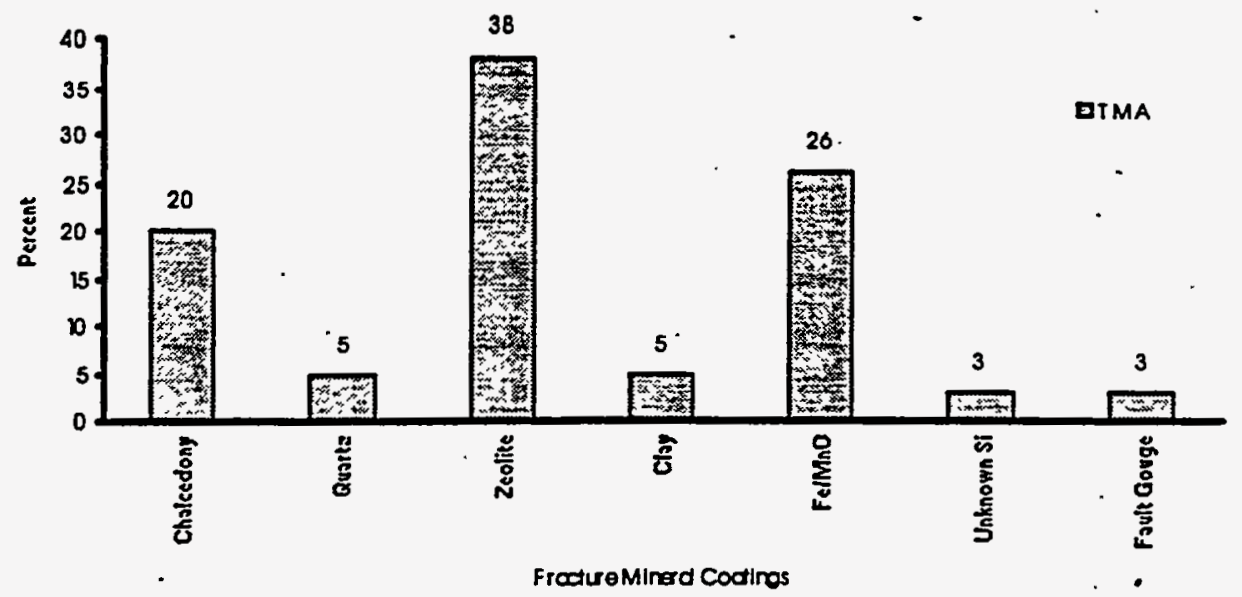

Figure 2-9a

Distribution of Fracture Mineral Coatings Relative to Hydrostratigraphy at UE-18r

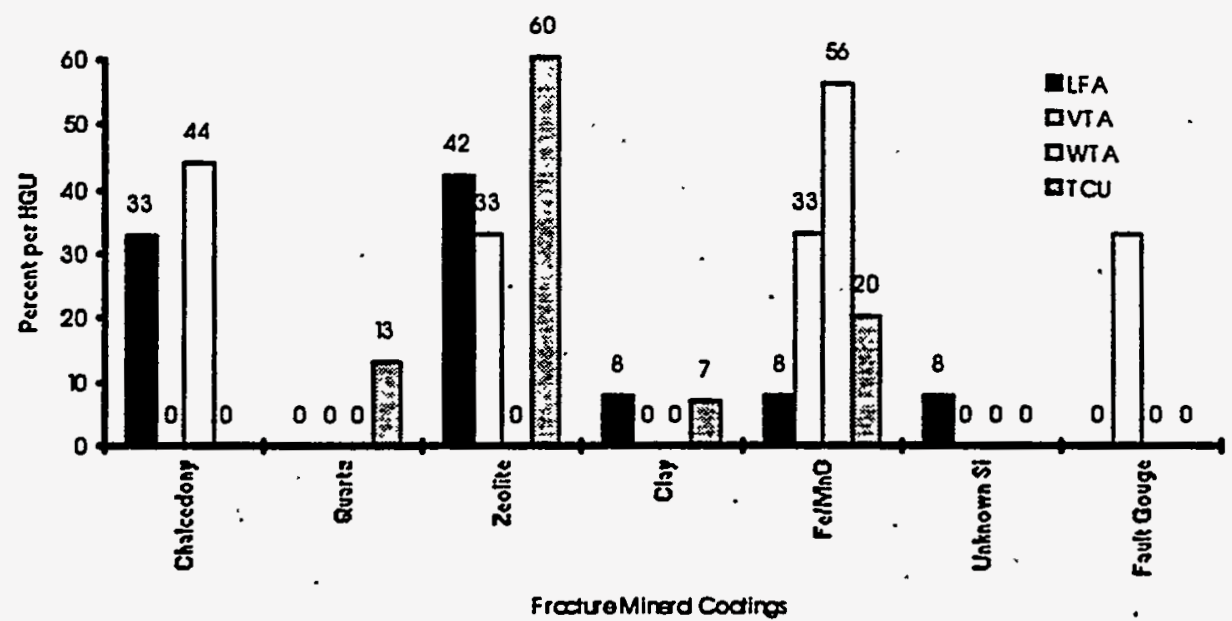

Figure 2-9b

Distribution of Fracture Mineral Coatings Relative to Hydrogeology at UE-18r

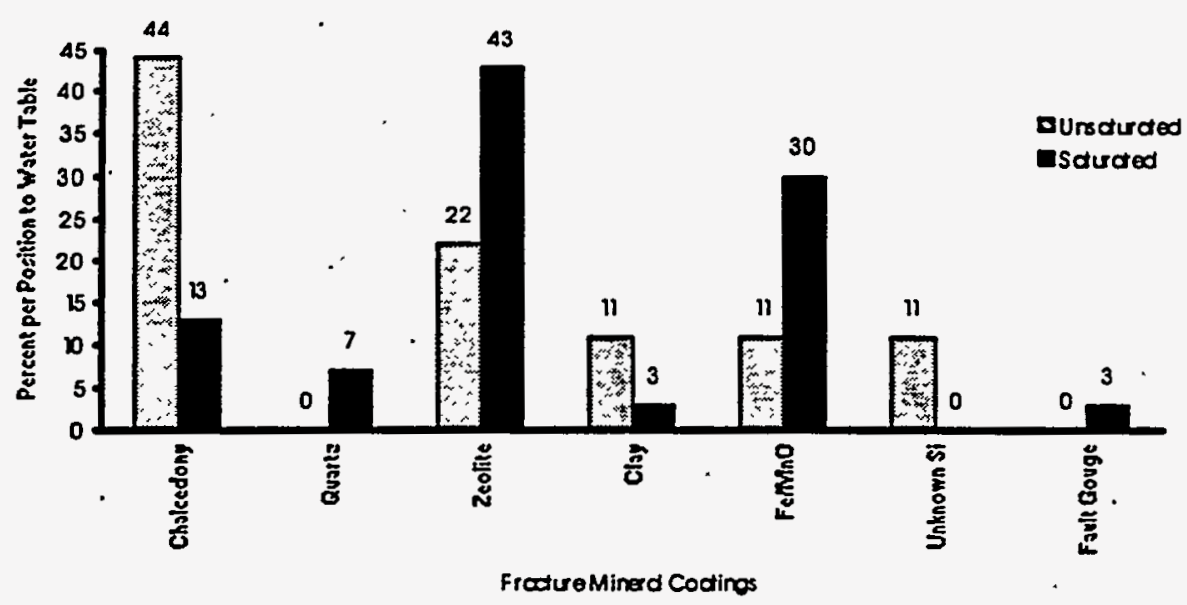

Figure 2-9c

Distribution of Fracture Mineral Coatings Relative to the Water Table at UE-18r

Figure 2-9a-c

Distribution of Fracture Mineral Coatings at UE-18r 


\section{Distribution of Fracture-Coating Minerals Relative to the Water Table}

The distribution of fracture-coating minerals relative to the water table in UE-18r is illustrated in Figure 2-9c. Chalcedony is the primary fracture-coating mineral present above the water table, followed by zeolites, with clay minerals, Fe/Mn oxides, and unidentified silicate minerals also present. Below the water table, zeolites are the most abundant fracture-coating material, followed by $\mathrm{Fe} / \mathrm{Mn}$ oxides with all other mineral species relatively uncommon.

\subsubsection{Comparisons of Fracture Data, Available Hydraulic Test Data, and Caliper Log}

Direct comparison between aquifer hydraulic tests conducted in the UE-18 $r$ wellbore and core fracture data is not straightforward. Only a small percentage ( 2.4 percent) of the borehole was cored; furthermore, the short intermittent cores do not always correlate to the much longer borehole hydrologic test intervals.

In general, given the above caveats, core fracture data correlates well with the hydraulic properties derived from tests conducted in 1968. The most transmissive intervals identified by borehole hydrologic tests correspond to fractured LFAs and WTAs. The impermeable zones correspond to less fractured zeolitized units classified hydrogeologically as TCUs. For example, one of the more permeable intervals, 676.7 to $681.2 \mathrm{~m} \mathrm{(2,220} \mathrm{to} \mathrm{2,235} \mathrm{ft)} \mathrm{noted} \mathrm{in} \mathrm{Carr,} \mathrm{et} \mathrm{al.}$ $(1968,1981)$ corresponds to a cored interval 679.1 to $680.9 \mathrm{~m}(2,228$ to $2,234 \mathrm{ft})$, where a high number of open fractures are observed. Two cores from 492.3 to $494.4 \mathrm{~m}(1,615$ to $1,622 \mathrm{ft})$ and 943.7 to 946.7 (3,096 to 3,106 ft) had no open fractures correspond to intervals having the lowest relative specific capacity values in the borehole (Figure 2-10). Note also that there is a fair correlation between borehole rugosity, as indicated by the caliper $\log$ and relative specific . capacity values.

Analysis of more recent flow meter data indicate that a complex hydrologic flow regime may exist within the UE-18r borehole (Paillet, 1991). However, there is some question regarding the

quality of this data and the validity of the flow meter tests under the existing borehole conditions (Paillet, 1994 and Adams, 1994). Because of this uncertainty, the flow meter results were not included in this fracture study. 


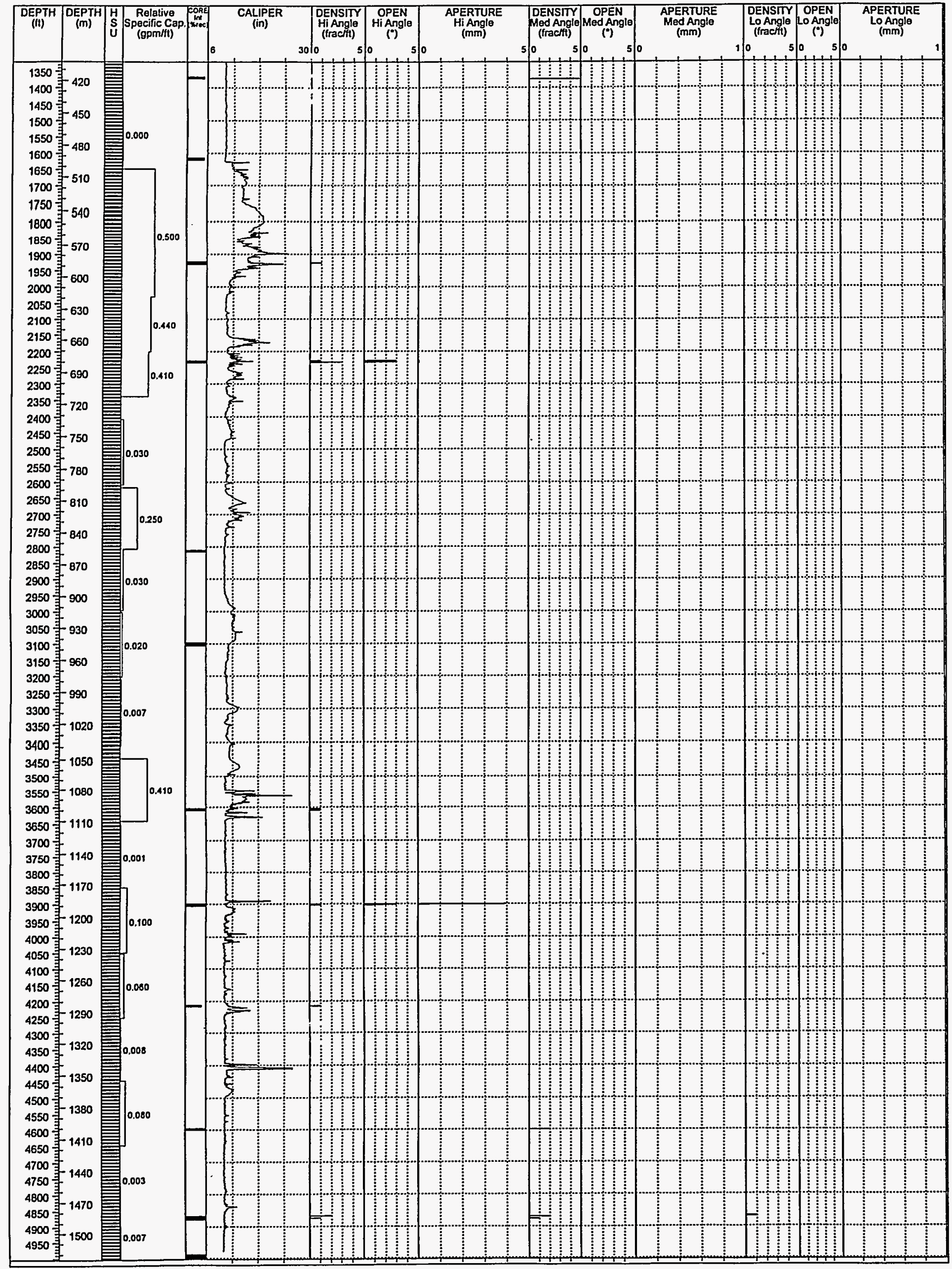


Hydrostratigraphic Unit (HSU)

\begin{tabular}{ll}
\hline & Timber Mountain Aquifer (TMA) \\
& Buff Cone (TC) \\
\hline & Belted Range Aquifer (TBA) \\
\hline
\end{tabular}

$$
{ }^{(0)} \text { (for all angles) }
$$

\begin{tabular}{cc} 
Number & Estimated Ronge of Percent Openness \\
\hline 0 & $0 \%$ \\
1 & $1-10 \%$ \\
2 & $10-50 \%$ \\
3 & $50-90 \%$ \\
4 & $90-99 \%$ \\
5 & $100 \%$
\end{tabular}




\subsection{Exploratory Hole UE-20e\#1}

\subsubsection{Hole History}

The UE-20e\#1 drill hole is located near the north flank of Pahute Mesa in northern Area 20 of the NTS at an elevation of $1,919.3 \mathrm{~m}(6,297 \mathrm{ft}$ ) (Figure 1-1). The hole was drilled to a TD of. $1,949.2 \mathrm{~m}(6,395 \mathrm{ft})$ as part of an exploratory program conducted in 1964 to investigate sites prior to drilling emplacement holes (Hoover, 1964). Drill hole UE-20e\#1 replaced the UE-20e drill hole that was prematurely abandoned at a depth of $737.6 \mathrm{~m}(2,420 \mathrm{ft}$ ) (Hoover, 1964). Table C-8 in Appendix $\mathrm{C}$ is an abridged summary of the drill hole statistics for the hole. The UE-20e\#1 drill hole was intermittently cored during the drilling operation, and the core intervals are included in Table C-9 in Appendix C.

\subsubsection{Hydrogeology}

The UE-20e\#1 drill hole is located in a north-south trending structural block within the buried, Silent Canyon caldera complex. The structural block is bound on the west side by the westdipping, high-angle Purse fault, and on the east side by the Boxcar fault that has similar structural kinematics. The surface geology near the drill hole includes flat-lying, volcanic strata of the Trail Ridge Tuff (Ekren et al., 1966).

This area is also included in the Southeastern Gold Flat structural block, as defined by Warren (1994). The TMA, TC, and TBA comprise the primary HSUs associated with this block as defined by area drill holes. The following HSUs were encountered in the UE-20e\#1 drill hole:

- The TMA from the surface to $424.6 \mathrm{~m}(1,393 \mathrm{ft})$, which includes bedded tuff and partially welded to densely welded ash-flow tuff of the Thirsty Canyon Group and Timber Mountain Group

- The TC from $424.6 \mathrm{~m}(1,393 \mathrm{ft})$ to $1,558.7 \mathrm{~m}(5,114 \mathrm{ft})$, which consists primarily of lavas and zeolitized bedded tuffs of the Volcanics of Area 20

- The TBA from $1,558.7 \mathrm{~m}(5,114 \mathrm{ft})$ to $\mathrm{TD}$, which includes mostly devitrified to zeolitized lava flows and bedded tuffs of the Belted Range Group.

The condensed lithologic log and the stratigraphic record for UE-20e\#1 are included in Table C-10 in Appendix C.

Hydrologic tests conducted in UE-20e\#1 are discussed in Section 2.4.4. 
The UE-20e\#1 drill hole was included in the study to provide fracture characteristics in the saturated section of the lower part of the TC and the TBA HSUs. Only the core intervals that contain these HSU intervals from $1,188.7 \mathrm{~m}(3,900 \mathrm{ft})$ to TD were analyzed for fracture characteristics.

\subsubsection{Fracture Analysis}

\subsubsection{Density and Distribution}

The density of fractures in the core sections from UE-20e\#1 has been analyzed relative to occurrence within various HSUs and HGUs and relative to fracture orientation. In these analyses, the distribution of fractures has been examined separately for open and closed fractures. These relationships are shown in Figures 2-11 and 2-12a-c and discussed below.

\section{Vertical Distribution of Open and Closed Fractures}

Figure 2-11 shows the cored intervals examined and the vertical distribution of open and closed fractures within HGUs and HSUs in the UE-20e\#1 core. The figure also presents data about the aperture, openness, and density of fractures at high, medium, and low angles. The figure also illustrates the relationship of fracture distribution to the caliper log.

\section{Density of Open and Closed Fractures in Hydrostratigraphic Units}

The cored intervals examined from Exploratory.Hole UE-20e\#1 represent strata that have been assigned to the TC and the TBA. The density of closed and open fractures is significantly higher in the TBA than in the TC. The density of closed fractures in the TBA is twice that of open fractures and even greater in the TC (Figure 2-12a).

\section{Density of Open and Closed Fractures in Hydrogeologic Units}

Two HGUs (the LFA and the TCU) are represented in the UE-20e\#1 core. The density of open and closed fractures is significantly higher in the LFA than in the TCU. In both HGUs, the density of closed fractures exceeds that of open fractures (Figure 2-12b).

\section{Distribution of Fractures Relative to Orientation}

In UE-20e\#1, the density of open and closed fractures are greatest at high-angle orientations. Closed fractures were also abundant at medium angles, but rare at low angles. 'The density of open fractures is negligible at medium and low angles (Figure 2-12c). 


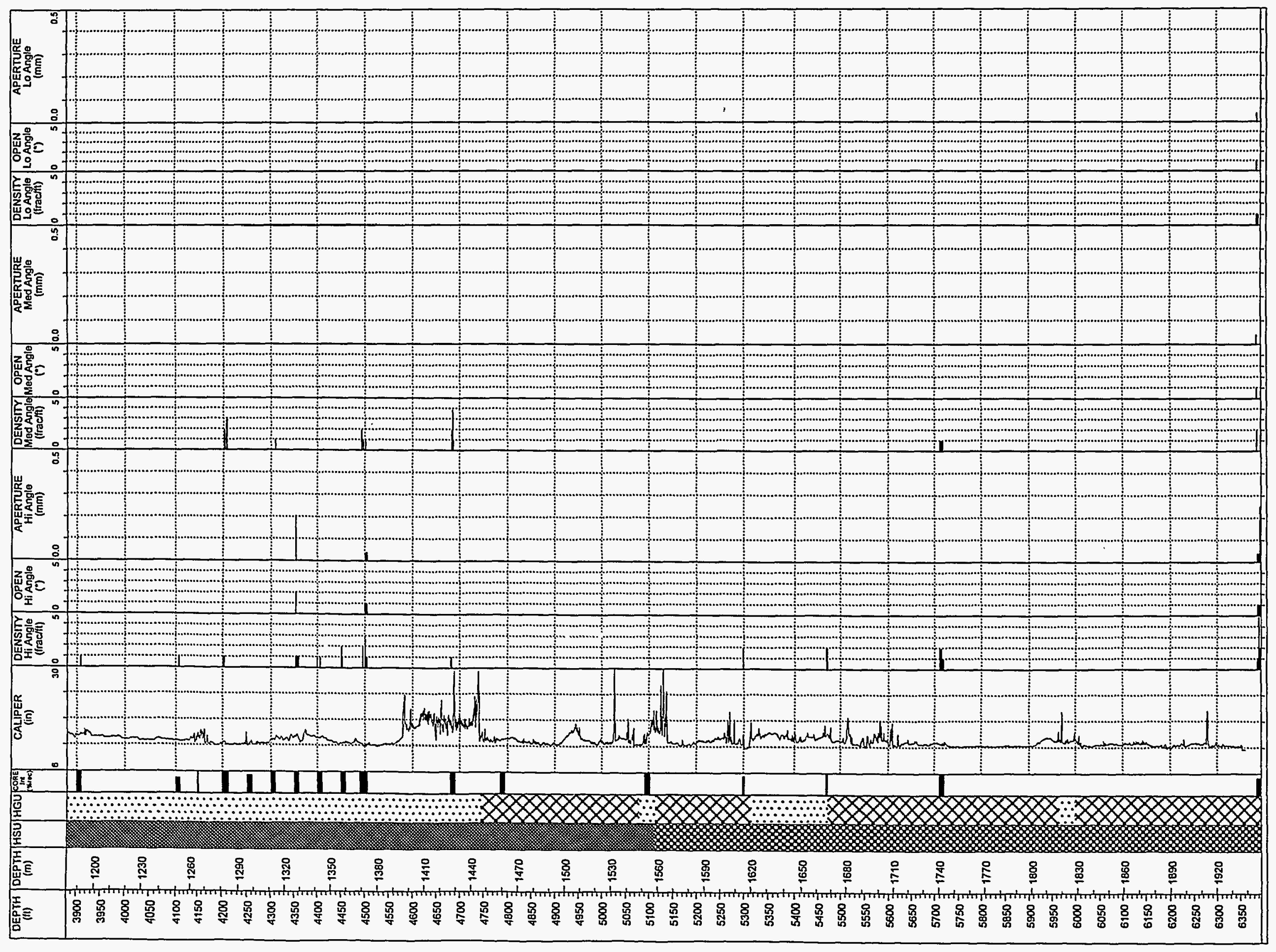




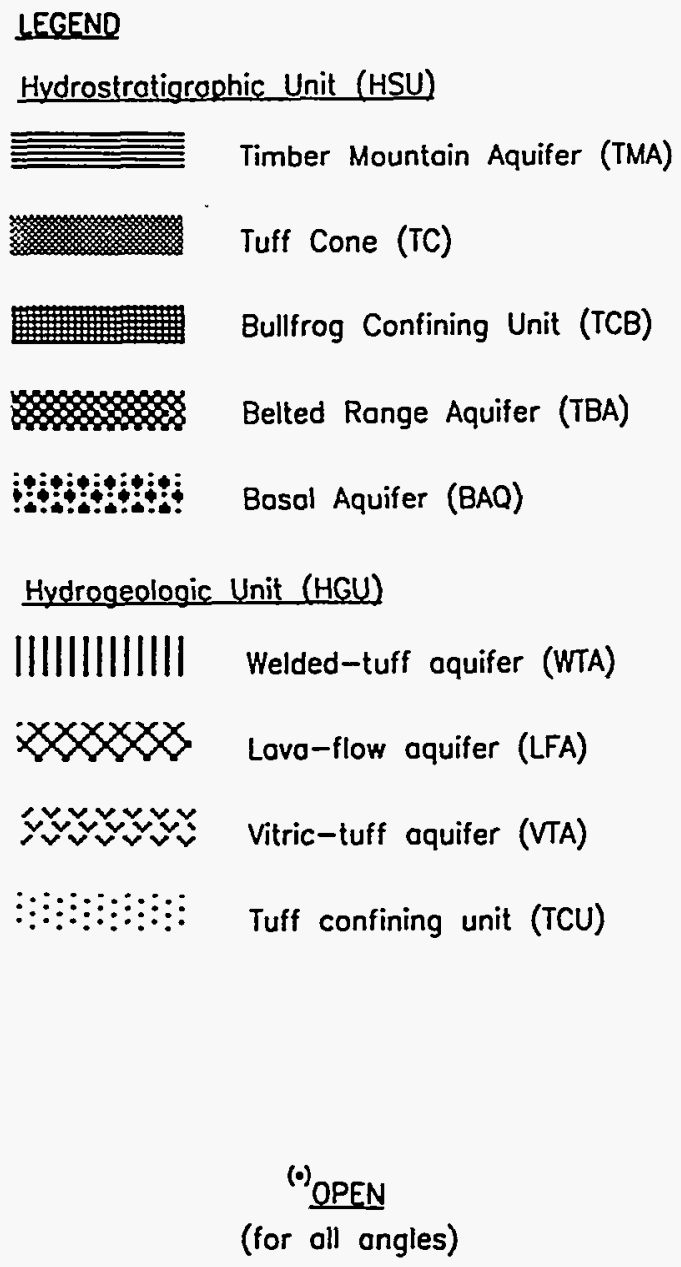



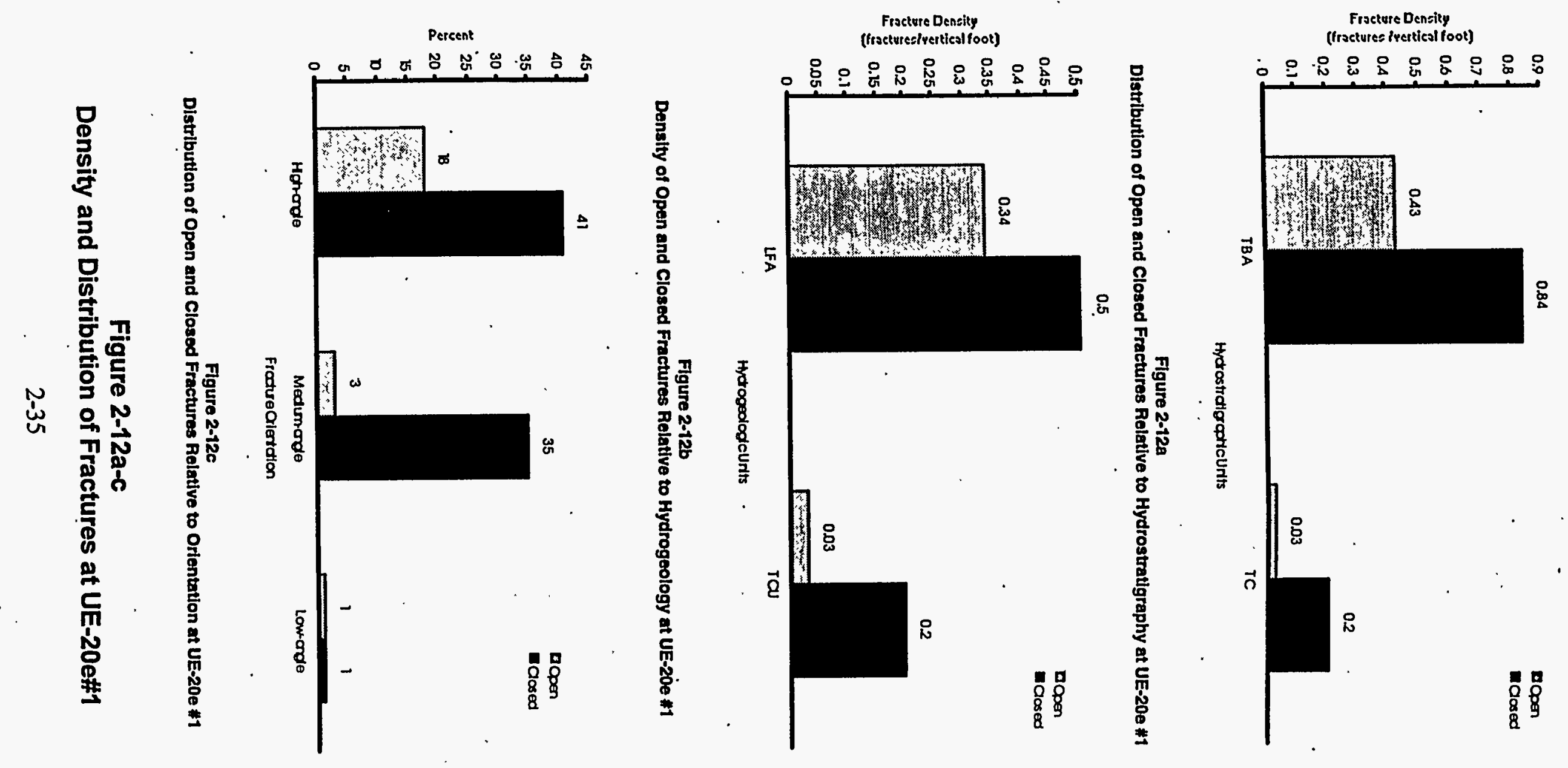


\subsubsection{Aperture and Fracture Openness}

Aperture and percent openness of open fractures in the UE-20e\#1 core have been analyzed relative to the HGUs and HSUs in which the fractures occur. These relationships are shown in Table 2-4 and discussed in the following text.

\section{Aperture and Openness Relative to Hydrostratigraphic Units}

Average apertures for fractures within both the TBA and TC are relatively small at $0.08 \mathrm{~mm}$ (0.003 in.) and $0.03 \mathrm{~mm}(0.001 \mathrm{in}$.), respectively (Table 2-4). Fractures within both HSU average $1-10$ percent open.

\section{Aperture and Openness Relative to Hydrogeologic Units}

The average aperture and percent open for fractures within the LFA is the same as that for TBA (Table 2-4). This same relationship also holds true with regard to the TCU and the TC.

Table 2-4

\section{UE-20e\#1 Fracture Aperture and Percent Open Data}

Data Grouped by Hydrostratigraphic Units

\begin{tabular}{||l|c|c||}
\hline \multicolumn{1}{|c|}{ Hydrostratigraphic Units } & $\begin{array}{c}\text { Average Aperture } \\
\text { (millimeters) }\end{array}$ & Percent Open \\
\hline \hline Tuff Cone (TC) & 0.03 & $1-10$ percent \\
\hline Belted Range Aquifer (TBA) & 0.08 & $1-10$ percent \\
\hline
\end{tabular}

Data Grouped by Hydrogeologic Units

\begin{tabular}{||l|c|c|}
\hline \multicolumn{1}{|c|}{ Hydrogeologic Unit } & $\begin{array}{c}\text { Average Aperture } \\
\text { (millimeters) }\end{array}$ & Percent Open \\
\hline \hline Lava-flow aquifer (LFA) & 0.08 & $1-10$ percent \\
\hline Tuff confining unit (TCU) & 0.03 & $1-10$ percent \\
\hline
\end{tabular}




\subsubsection{Mineralogy of Fracture Coatings}

\section{Distribution of Fracture-Coating Minerals in Hydrostratigraphic Units}

The distribution of fracture-coating minerals in the two HSUs present in the UE-20e\#1 core (the TBA and the TC) is presented in Figure 2-13a. Zeolites (clinoptilolite and mordenite) are the predominant fracture-coating or -filling minerals in the TC, with other minerals (clays, chalcedony, quartz, vapor-phase silicates, and $\mathrm{Fe} / \mathrm{Mn}$ oxides) being relatively rare. In contrast, $\mathrm{Fe} / \mathrm{Mn}$ oxides are the dominant fracture-coating mineral in the TBA, followed by zeolites and clays.

\section{Distribution of Fracture-Coating Minerals in Hydrogeologic Units}

The distribution of fracture-coating minerals in the two HGUs present in the UE-20e\#1 core (the LFA and the TCU) is presented in Figure 2-13b. Because the LFA is essentially equivalent to the TBA HSU and the TCU is equivalent to the TC HSU in this core, the distribution of mineral coatings is essentially the same for HGUs as for the HSUs.

\subsubsection{Comparison of Fracture Data, Available Hydraulic Test Data, and Caliper Logs}

Hydrologic tests were conducted in UE-20e\#1 in 1964 (Hoover, 1964) to determine the water-yielding potential of the volcanic rock and to ascertain whether the site is suitable for an emplacement hole. In most cases, the tests were intentionally limited to low permeable zones that would be favorable to the development of mined chambers.

When the hydrologic data from the test intervals are compared to the fracture data derived from the analyzed core, only limited qualitative conclusions can be reached. The very small ratio of available core to the hydrologic test interval precludes a useful comparison.

The hydrologic tests included isolating six 60.4-m (198-ft) intervals and one 565.4-m (1,855-ft) interval with packers and conducting either injection or swab tests. The test results indicate very low relative specific capacities in the 60.4-m (198-ft) intervals (ranging from $0.014-0.130$ gallons per minute per foot of drawdown). The relative specific capacity in the 565.4-m $(1,855-\mathrm{ft})$ interval was not recorded because there was no measurable drawdown five minutes after swabbing ceased (Hoover, 1964). Only three test intervals with data correspond with core examined in this study, and they are presented on Figure 2-14 as they compare to fracture distribution and caliper logs. 


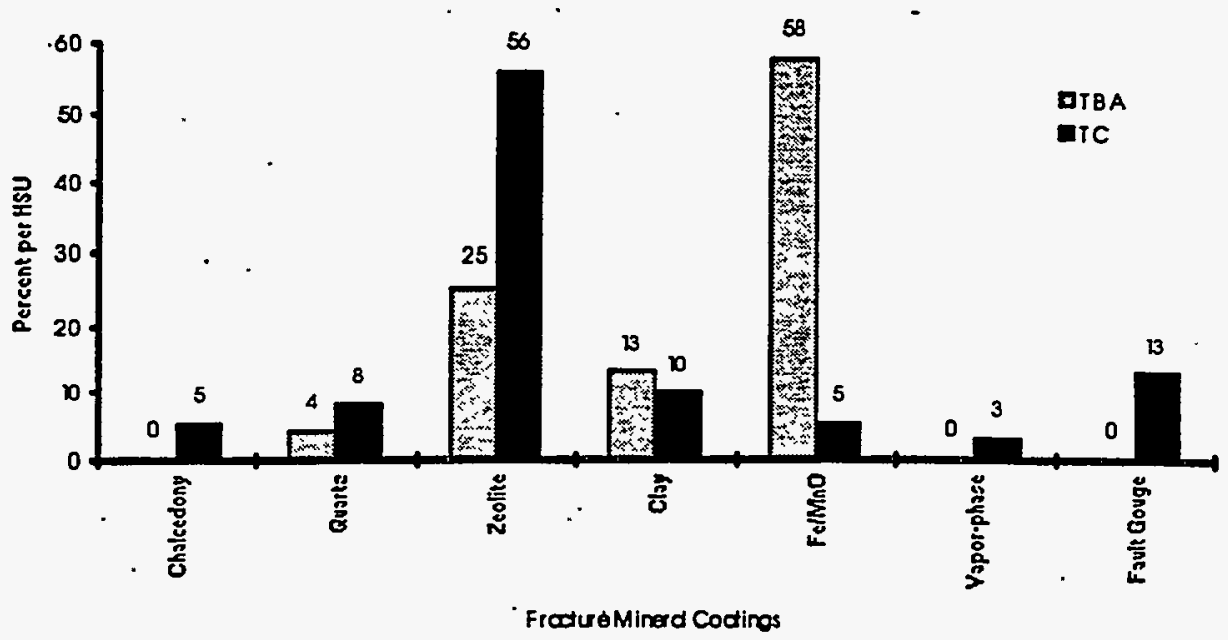

Figure 2-13a

Distribution of Fracture Mineral Coatings Relative to Hydrostratigraphy at UE-20e \#1

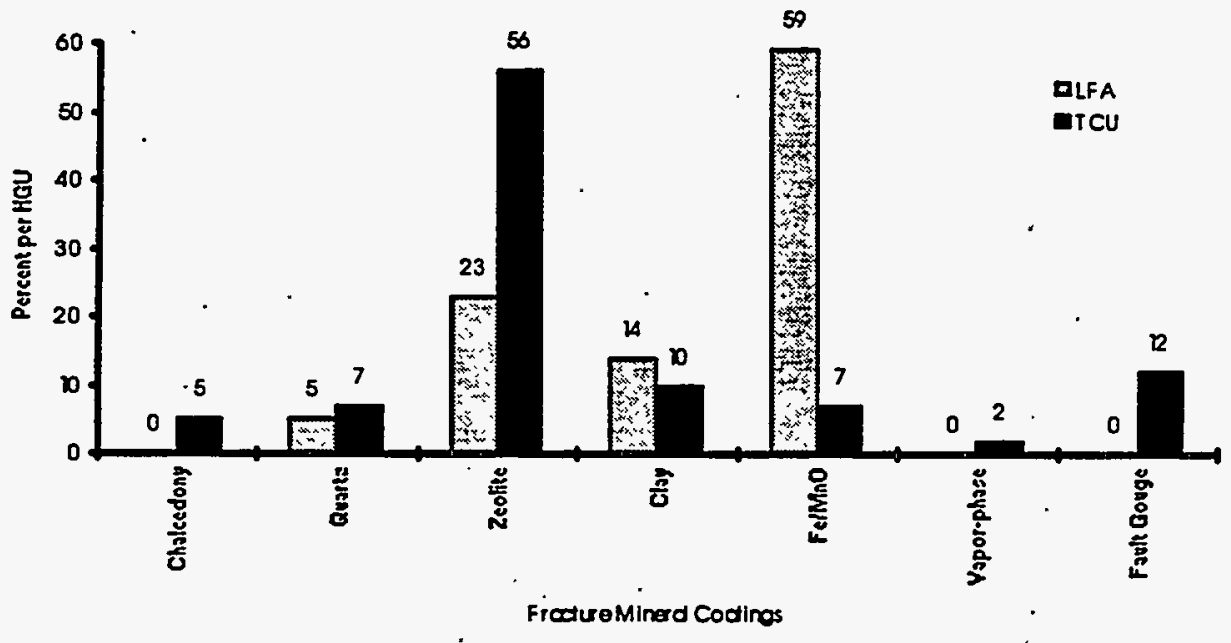

Figure 2-13b

Distribution of Fracture Mineral Coatings Relative to Hydrogeology at UE-20e \#1

Figure 2-13a-b

Distribution of Fracture Mineral Coatings at UE-20e \#1 


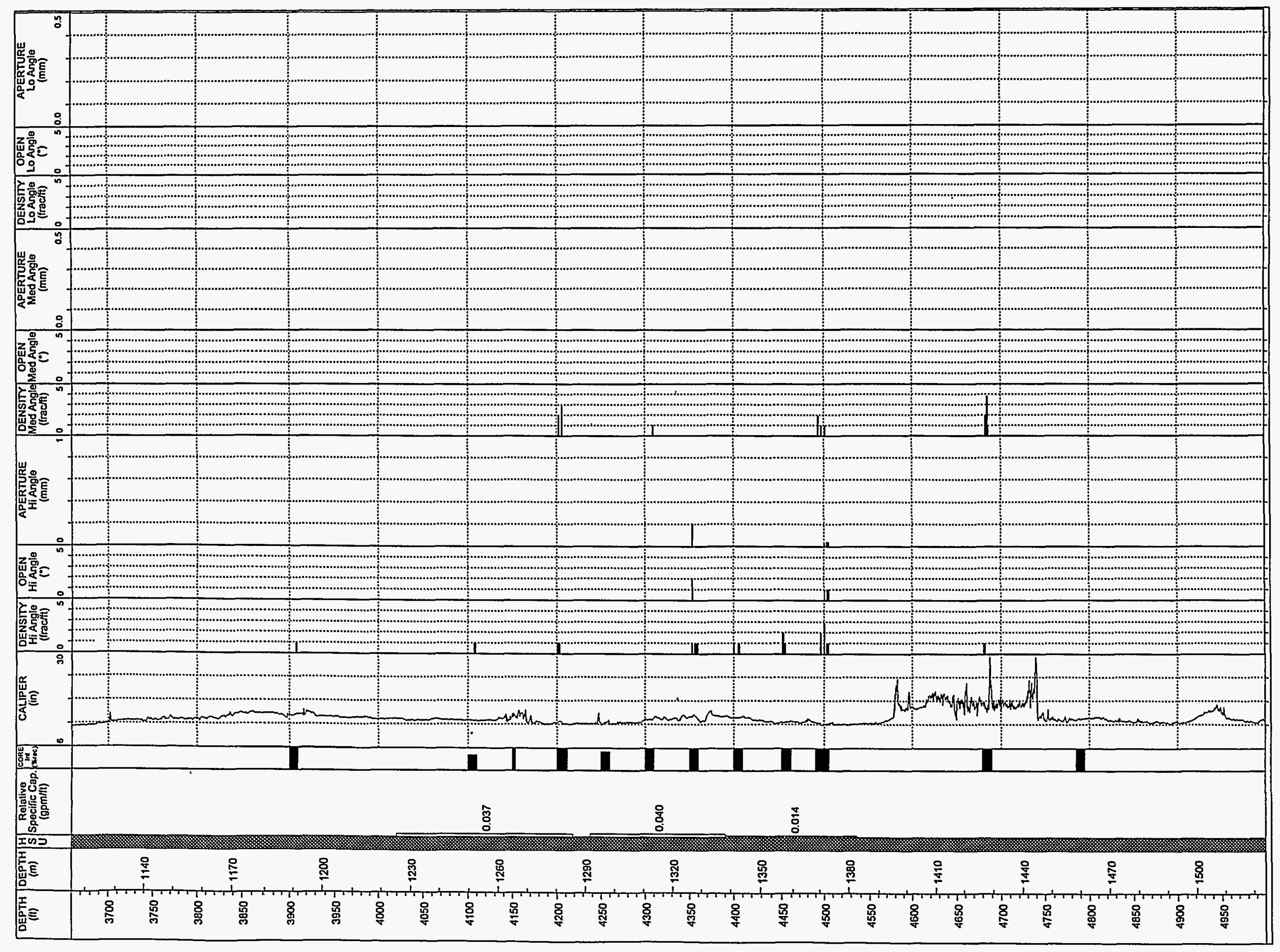


LEGEND

Hydrostrotigroghic Unit (HSU)

\begin{tabular}{ll}
\hline & Timber Mountoin Aquifer (TMA) \\
Buff Cone (TC) & Bullfog Confining Unit (TCB) \\
& \\
\hline & Belted Ronge Aquifer (TBA) \\
&
\end{tabular}

$$
\stackrel{(\circ)}{\text { OPEN }}
$$

\begin{tabular}{cc} 
Number & Estimated Ronge of Percent Openness \\
\hline 0 & $0 \%$ \\
1 & $1-10 \%$ \\
2 & $10-50 \%$ \\
3 & $50-90 \%$ \\
4 & $90-99 \%$ \\
5 & $100 \%$
\end{tabular}

Figure 2-14

UE-20e \#1: Composite Log of Hydrologic Test Dała, Caliper Log, and Fracture Dała, 1,115.6 - 1,524 Meters 
In each of the 60.4-m (198-ft) intervals, the low relative specific capacities compared favorably with the low fracture densities that ranged from 0-3 fractures per interval with less than 10 percent openness. Although the fracture data agree with the results of the tests from a qualitative standpoint, it is important to note that on average, less than 18 percent of the hydrologic test interval had core available for fracture analysis.

The caliper log on Figure 2-14 indicates some degree of borehole rugosity through the 60.4-m (198-ft) test zones. The rugosity does not appear to be directly associated with fractured intervals or flow zones as indicated by the hydrologic test results and limited fracture data.

\subsection{Monitoring Well UE-20bh\#1}

\subsubsection{Hole History}

The UE-20bh\#1 drill hole is located on Pahute Mesa in eastern Area 20 of the NTS at an elevation of 2,022.8 $\mathrm{m}$ (6,636.6 ft) (see Figure 1-1). The hole was drilled in 1991 to a total depth of $856.5 \mathrm{~m}$ (2,810 ft) as part of the Hydrologic Radionuclide Migration Program (HRMP) to investigate and characterize groundwater flow in southeast Pahute Mesa (Boyd et al., 1992). The hole was intermittently cored during the drilling operation at three separate intervals. Table C-11 in Appendix $C$ is an abridged summary of the drill hole statistics for UE-20bh\#1, and Table C-12 in Appendix $\mathrm{C}$ includes the core intervals.

The primary purpose for including UE-20bh\#1 in the fracture study was to compare fracture characteristics derived from the core to characteristics interpreted from the BHTV and FMS logs. A secondary objective was to collect additional fracture data to expand the TC data set.

\subsubsection{Hydrogeology}

The UE-20bh\#1 drill hole is located in a north-south trending structural block within the Silent Canyon caldera complex. The structural block is bound on the west side by the west-dipping, West Greely fault, and on the east side by the west-dipping, East Greely fault system. The surface geology in the area includes gentle, east dipping, volcanic strata of the Timber Mountain group and a local, thin veneer of alluvium. This area is also included in the Central Area 19 structural block (Warren, 1994).

The TMA, TC, TCB, and TBA comprise the primary HSUs associated with this block as defined by drill holes in the area. UE-20bh\#1 penetrated only volcanic rocks of the TMA and TC HSUs. From below $169.2 \mathrm{~m}(955 \mathrm{ft}$ ) to total depth, the drill hole penetrated approximately $687.3 \mathrm{~m}$ 
(209 ft) of caldera-filling rock types representing the TC. These include various lavas and tuffs of the Calico Hills Formation. From the surface to the top of the Calico Hills Formation, the drill hole encountered caldera-burying units consisting of ash-flow and bedded tuffs of the Rainier Mesa Tuff that are included in the TMA. The lithology and the stratigraphic record for the hole are provided in Table $\mathrm{C}-13$ in Appendix C.

The static water level at UE-20bh\#1 is reported at $674.7 \mathrm{~m}(2,214 \mathrm{ft})$ depth. Open-hole pumping tests were conducted in 1991 as part of the HRMP characterization effort at this site (Boyd et al., 1992). These test results are discussed in Section 2.5.4.

\subsubsection{Fracture Analysis}

\subsubsection{Density and Distribution}

The density of fractures in the core sections from UE-20bh\#1 has been analyzed relative to occurrence within the HSU and HGUs and relative to fracture orientation. In these analyses, the distribution of fractures has been examined separately for open and closed fractures. These relationships are shown in Figures 2-15 and 2-16a-c and discussed in the following text.

\section{Vertical Distribution of Open and Closed Fractures}

Figure 2-15 shows the cored intervals examined and the vertical distribution of open and closed fractures within HGUs and HSU in the UE-20bh\#1 core. The figure also presents data on the aperture, openness, and density of fractures at high, medium, and low angles. The figure also shows the relationship of fracture distribution to the caliper log.

\section{Density of Open and Closed Fractures in Hydrostratigraphic Units}

All strata represented in the cored intervals from Monitoring Well UE-20bh\#1 have been assigned to the TC. The density of closed fractures is significantly higher than the density of open fractures in the TC (Figure 2-16a). 


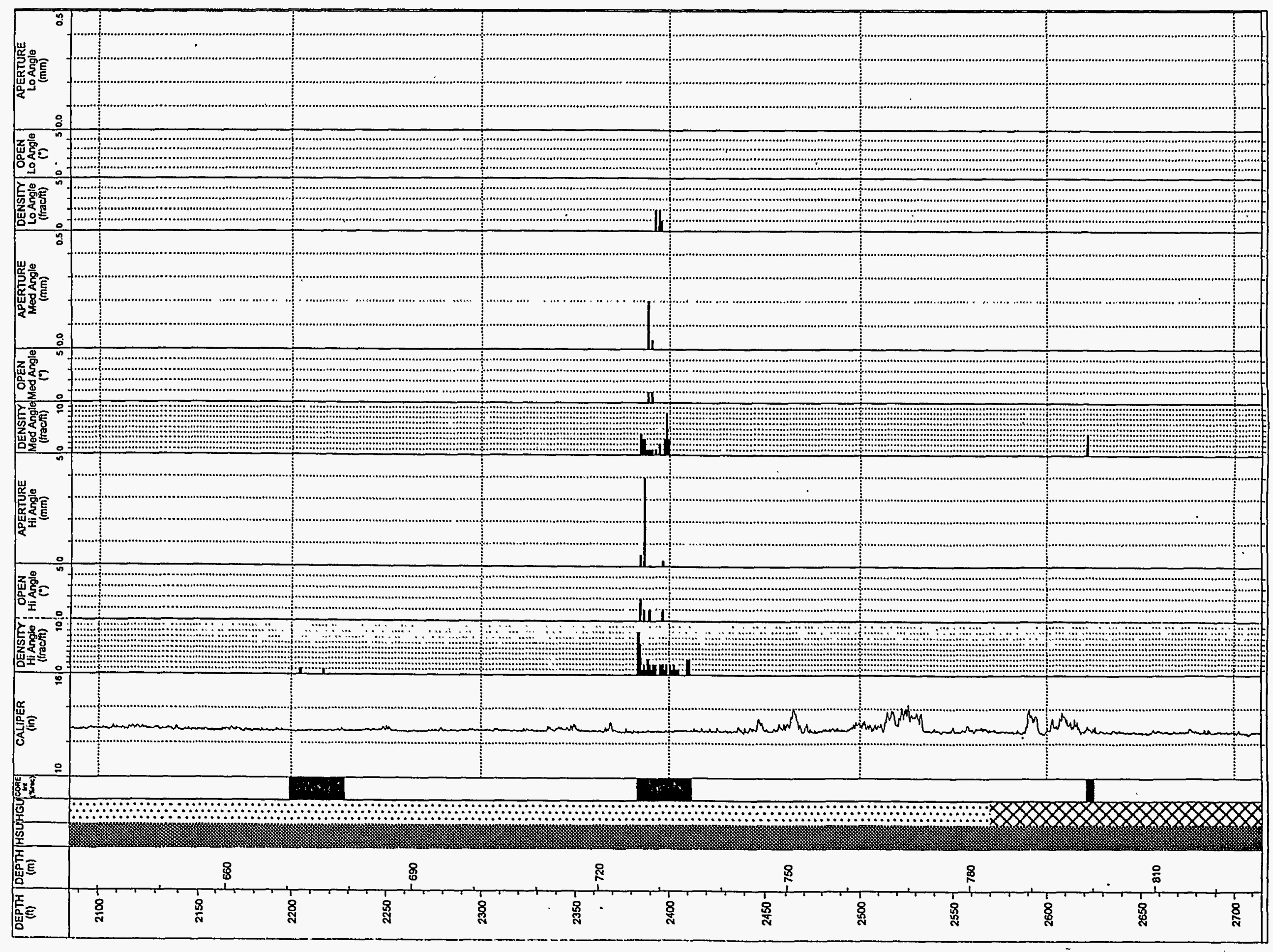




\section{LEGEND}

Hydrostrotigrophic Unit (HSU)

Timber Mountain Aquifer (TMA)

Tuff Cone (TC)

Bullfrog Confining Unit (TCB)

Belted Range Aquifer (TBA)

aquifer (BAQ)

Hydrogeologic Unit (HGU)

IIHIIHIHHI Welded-tuff oquifer (WTA)

$\times \times \times \times \times \times$ Lava-flow aquifer (LFA)

(VTA)

$: \because: \vdots: \vdots: \vdots: \vdots$ Tuff confining unit (TCU)

$$
{ }^{()^{O} \mathrm{OPEN}}
$$

Number Estimated Ronge of Percent Openness

0

$0 \%$

$1-10 \%$

$10-50 \%$

$50-90 \%$

$90-99 \%$

$5 \quad 100 \%$

Figure 2-15

UE-20bh \#1: Composite Log of Open and Closed Fracture Data, 635.5 - 827.5 Meters 


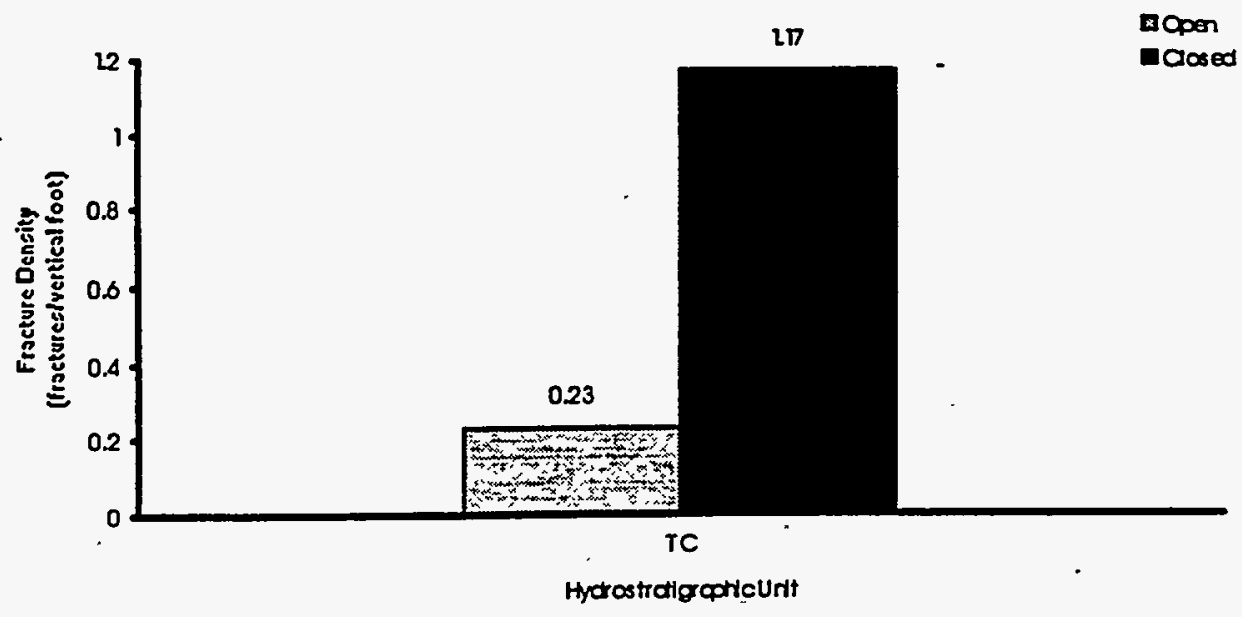

Figure 2-16a

Density of Open and Closed Fractures Relative to Hydrostratigraphy at UE-20bh *1

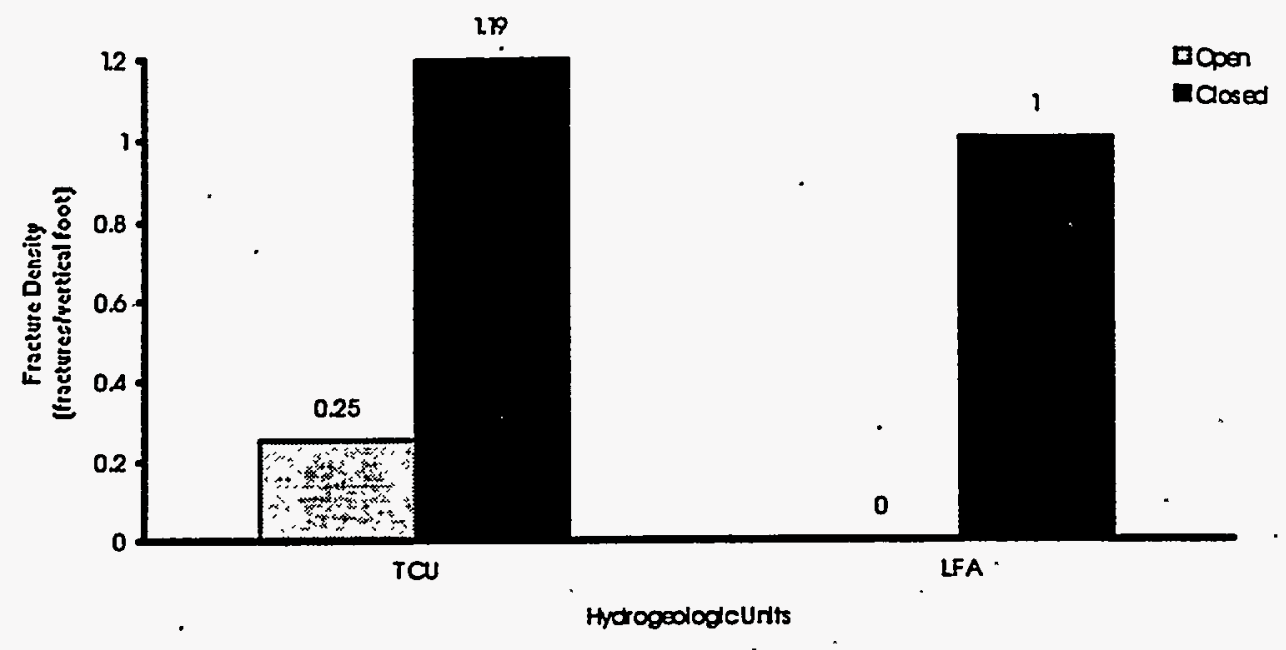

Figure 2-16b

Density of Open and Closed Fractures Relative to Hydrogeology at UE-20bh *1

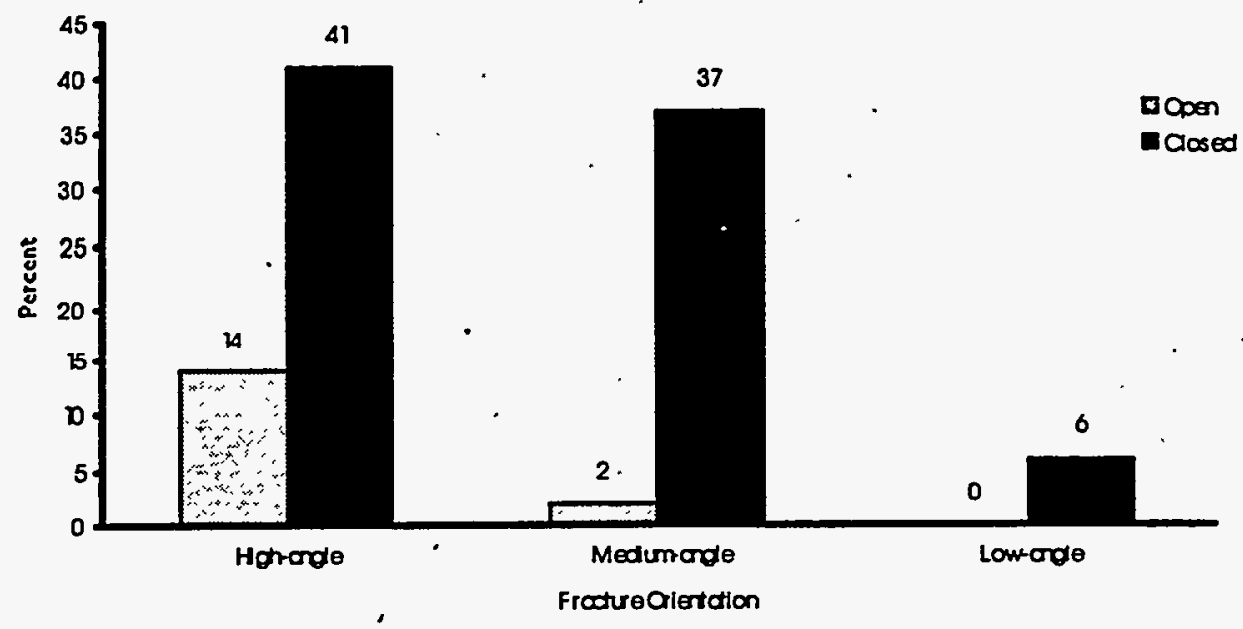

Figure 2-16e

Distribution of Open and Closed Fractures Relative to Orlentation at UE-20bh *1

Figure 2-16a-c

Density and Distribution of Fractures at UE-20bh \#1 


\section{Density of Open and Closed Fractures in Hydrogeologic Units}

Two HGUs (the LFA and the TCU) are represented in the UE-20bh\#1 core. In the TCU, the density of closed fractures greatly exceeds that of open fractures; in the LFA, all fractures were closed (Figure 2-16b). Note, however, that only $1.2 \mathrm{~m}(4 \mathrm{ft})$ of LFA was cored.

\section{Distribution of Open and Closed Fractures Relative to Orientation}

In UE-20bh\#1, the percentage of open and closed fractures are greatest at high-angle orientations. Closed fractures were also abundant at medium angles, but rare at low angles. The percentage of open fractures is negligible dium and low angles (Figure 2-16c).

\subsubsection{Aperture and Fracture Openness}

Aperture and percent openness of open fractures in the UE-20bh\#1 core have been analyzed relative to the HGUs and the HSU in which the fractures occur. These relationships are shown in Table 2-5 and discussed in the following text.

\section{Aperture and Openness Relative to Hydrostratigraphic Units}

The average aperture for fractures within the TC, the only HSU cored at UE-20bh\#1, is $0.8 \mathrm{~mm}$ (0.03 in.) (Table 2-5). The fractures average $1-50$ percent open.

Table 2-5

UE-20bh \#1 Fracture Aperture and Percent Open Data

Data Grouped by Hydrostratigraphic Units

\begin{tabular}{||l|c|c|}
\hline \multicolumn{1}{|c|}{ Hydrostratigraphic Units } & $\begin{array}{c}\text { Average Aperture } \\
\text { (millimeters) }\end{array}$ & Percent Open \\
\hline Tuff Cone (TC) & 0.8 & $1-50$ percent \\
\hline
\end{tabular}

Data Grouped by Hydrogeologic Units

\begin{tabular}{|l|c|c|}
\hline \multicolumn{1}{|c|}{ Hydrogeologic Unit } & $\begin{array}{c}\text { Average Aperture } \\
\text { (millimeters) }\end{array}$ & Percent Open \\
\hline \hline Lava-flow aquifer (LFA) & $* 1$ & $* 1$ \\
\hline Tuff confining unit ${ }^{2}$ (TCU) & 0.8 & $1-50$ percent \\
\hline
\end{tabular}

1 Only $1.2 \mathrm{~m}$ (4 ft) of LFA logged; no open fractures.

2 Mostly zeolitized lava. 


\section{Aperture and Openness Relative to Hydrogeologic Units}

Fracture aperture within the TCU averages $0.8 \mathrm{~mm}(0.03 \mathrm{in}$.) (Table 2-5). The average percent open for the fractures is $1-50$ percent. No.open fractures were observed within the LFA.

\subsubsection{Mineralogy of Fracture Coatings}

\section{Distribution of Fracture-Coating Minerals in Hydrostratigraphic Units}

The distribution of fracture-coating minerals in the TC in the UE-20bh\#1 core is presented in Figure 2-17a. Zeolites, $\mathrm{Fe} / \mathrm{Mn}$ oxides, and chalcedony occur in approximately equivalent abundances and are the dominant fracture-coating or -filling minerals in the core. Euhedral quartz and calcite occur in some fractures. Clay minerals were not observed in UE-20bh\#1.

\section{Distribution of Fracture-Coating Minerals in Hydrogeologic Units}

The distribution of fracture-coating minerals in the two HGUs present in the UE-20bh\#1 core (the LFA and the TCU) is presented in Figure 2-17b. The differences between the two HGUs are noteworthy. In the LFA, all fractures are coated with chalcedony; no other minerals were observed. In the TCU, zeolites, Fe/Mn oxides, and chalcedony occur in roughly equal amounts with quartz and calcite present in minor amounts.

\subsubsection{Comparison of Fracture Data, Available Hydrologic Test Data, and Caliper Log}

Rudimentary step drawdown pumping tests were conducted in the open borehole as part of the HRMP (Allen, 1993). Preliminary evaluation of these largely unprocessed and unpublished data indicate the presence of an aquifer of only moderate transmissivity. This is consistent with the hydrogeology of the saturated section; roughly 40 percent LFA (the bottom $73.2 \mathrm{~m}$ [240 ft] of the borehole) and 60 percent TCU. This ratio is not uncommon for the TC HSU.

The comparison between the fracture data and hydrologic test data is inconclusive, due to the limited amount of core and the nature of the tests. Furthermore, the caliper log provides no indication of the fractured interval at 726.3 to $735.2 \mathrm{~m}(2,383-2,412 \mathrm{ft}$ ) (Figure 2-15). 


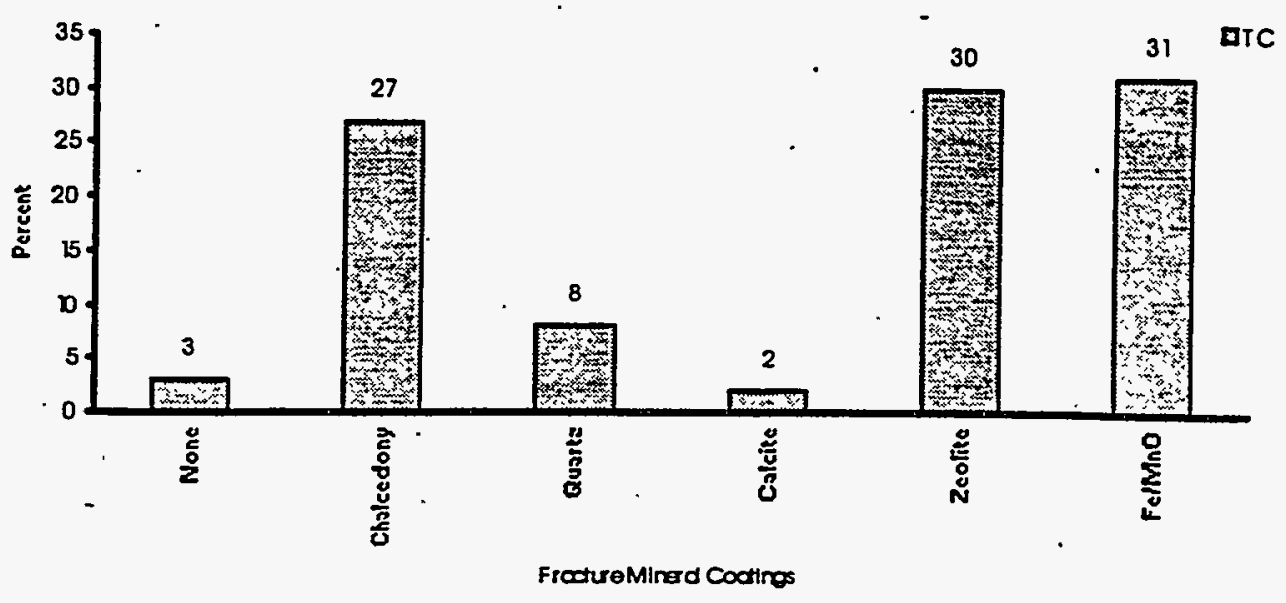

Figure 2-17a

Distribution of Fracture Mineral Coatings Relative to Hydrostratigraphy at UE-20bh \#1

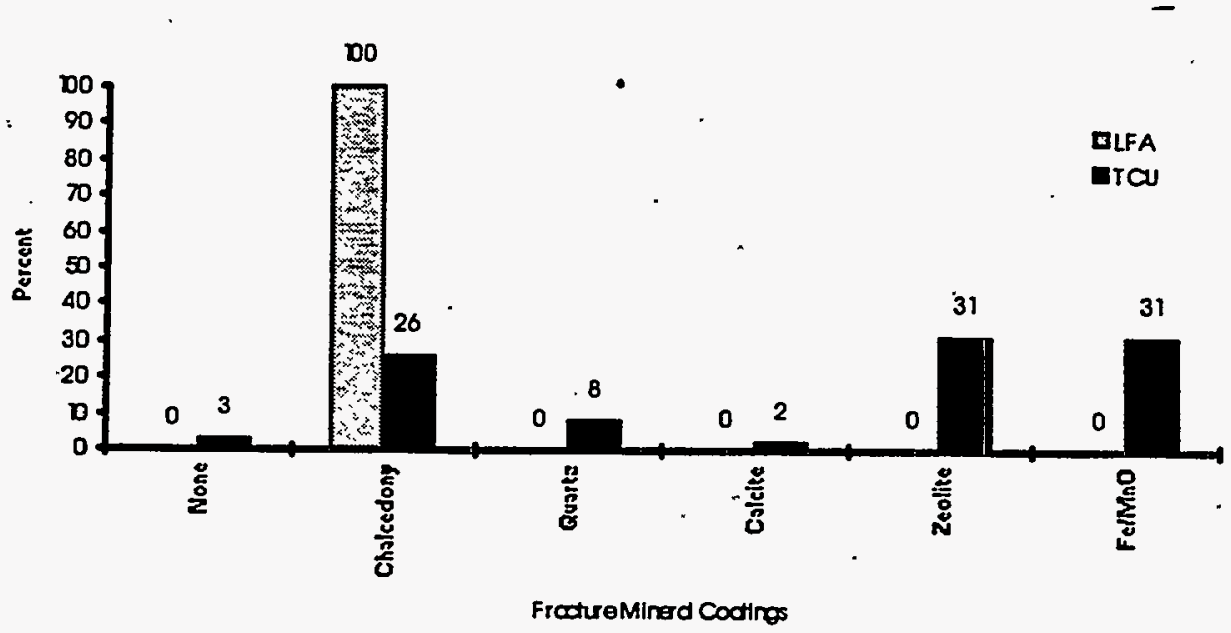

Figure 2-17b

Distribution of Fracture Mineral Coatings Relative to Hydrogeology at UE-20bh \#1 


\subsection{Emplacement Hole U-20c and Exploratory Hole UE-20c}

\subsubsection{Well Histories}

Exploratory Hole UE-20c is located in south central Pahute Mesa in Area 20 of the NTS (Figure 1-1). The hole was drilled in 1964 to characterize the subsurface geology prior to drilling nearby Emplacement Hole U-20c. UE-20c was rotary-drilled to a TD of 1,630.1 m $(5,348 \mathrm{ft})$, short of the planned TD of $1,828.8 \mathrm{~m}(6,000 \mathrm{ft})$ because of severe hole sloughing problems (Santos, 1964). Thirty-five intermittent cores were obtained at various intervals between the depth of 137.2 and $1,573.1 \mathrm{~m}(450-5,161 \mathrm{ft})$. A summary of drill hole data for UE$20 \mathrm{c}$ is provided in Table $\mathrm{C}-14$ in Appendix $\mathrm{C}$. Coring data are provided in Table $\mathrm{C}-15$ in Appendix C. Additional details regarding the UE-20c drill hole are included in Santos (1964).

Emplacement Hole U-20c is located $169.4 \mathrm{~m}(555.7 \mathrm{ft})$ west-northwest of UE-20c. This $1.83-\mathrm{m}$ (72-in.) diameter emplacement hole was rotary-drilled in 1964 using dual-string, reverse circulation with air-foam to a TD of $1,463 \mathrm{~m}(4,800 \mathrm{ft})$. Six conventional cores were centerpunched at various depths between $1,386.5$ to $1,463.0 \mathrm{~m}$ (4,549 to $4,800 \mathrm{ft}$ ). Table C-16 in Appendix $\mathrm{C}$ is a summary of drill hole data for Emplacement Hole U-20c; core data is provided in Table C-17 in Appendix C.

Core data from these two holes were included in this fracture study for two reasons: 1) The core represents important hydrogeologic units associated with the BENHAM event; and 2) These holes are close to the UGTA near-field drilling site, Well Cluster ER-20-5. The BENHAM event was a relatively large-yield (1.15 Megaton) underground nuclear test conducted in December, 1968 in Emplacement Hole U-20c (DOE, 1994). Subsequently, the site of this test has been the subject of several hydrologic and radionuclide migration studies (Brikowski, 1991). This existing body of data, along with work planned at Well Cluster ER-20-5, has a potentional to influence CAU near-field experiments and modeling.

The extra core from U-20c was added to supplement the core available from UE-20c. All core from U-20c, $36.6 \mathrm{~m}$ (120 ft), and core below the static water level from UE-20c, approximately $72.8 \mathrm{~m}$ (239 ft), were logged for this study.

\subsubsection{Hydrogeology}

The UE-20c drill hole is located within the Silent Canyon caldera complex. The hole is situated on a north-south trending structural block bounded on the west by the Purse fault and on the east 
by the West Boxcar fault. This block is included in the Western Area 20 structural block (Warren, 1994).

Exploratory Hole UE-20c penetrated $67.1 \mathrm{~m}$ ( $220 \mathrm{ft}$ ) of welded ash-flow and bedded tuffs related to the Thirsty Canyon Group and Volcanics at Fortymile Canyon; $222.5 \mathrm{~m}$ (730 ft) of welded ash-flow tuffs and minor bedded tuffs related to the Timber Mountain Group; and $640 \mathrm{~m}$ $(2,100 \mathrm{ft})$ of rhyolite lavas, welded ash-flow tuffs and bedded tuffs related to the Paintbrush Group; and $700.4 \mathrm{~m}$ (2,298 ft) of interbedded lavas and bedded tuffs related to the Volcanics of Area 20. For simplicity, the stratigraphic and lithologic logs for both holes have been combined and referenced as the deeper hole, UE-20c, in Table C-18, in Appendix C.

All core examined is from the TC HSU. HGUs represented include the WTA, LFA, and the TCU. The static water level is about $648 \mathrm{~m}(2,126 \mathrm{ft})$ deep. Limited hydrogeologic tests (injection and swabbing) were conducted in 1964 within the center-punched portion of the U-20 $\mathrm{c}^{\circ}$ drill hole, 1,390 to $1,463 \mathrm{~m}(4,560$ to $4,800 \mathrm{ft})$ depth (Santos, 1964). These tests will be discussed in Section 2.6.4.

\subsubsection{Fracture Analysis}

\subsubsection{Density and Distribution}

The density of fractures in the core sections from U-20c/UE-20c has been analyzed relative to occurrence within the HSU and HGUs and relative to fracture orientation. In these analyses, the distribution of fractures has been examined separately for open and closed fractures. These relationships are shown in Figures 2-18 and 2-19a-c and discussed in the following text.

\section{Vertical Distribution of Open and Closed Fractures}

Figure 2-18 shows the cored intervals examined and the vertical distribution of open fractures in the HGUs and the TC HSU in the U-20c/UE-20c core. The figure also summarizes data on the aperture, openness, and density of fractures at high, medium, and low angles.

\section{Density of Open and Closed Fractures in Hydrostratigraphic Units}

All strata represented in the cored intervals from boreholes U-20c/UE-20c have been assigned to the TC. The density of open fractures is slightly higher than the density of closed fractures in the TC (Figure 2-19a). 


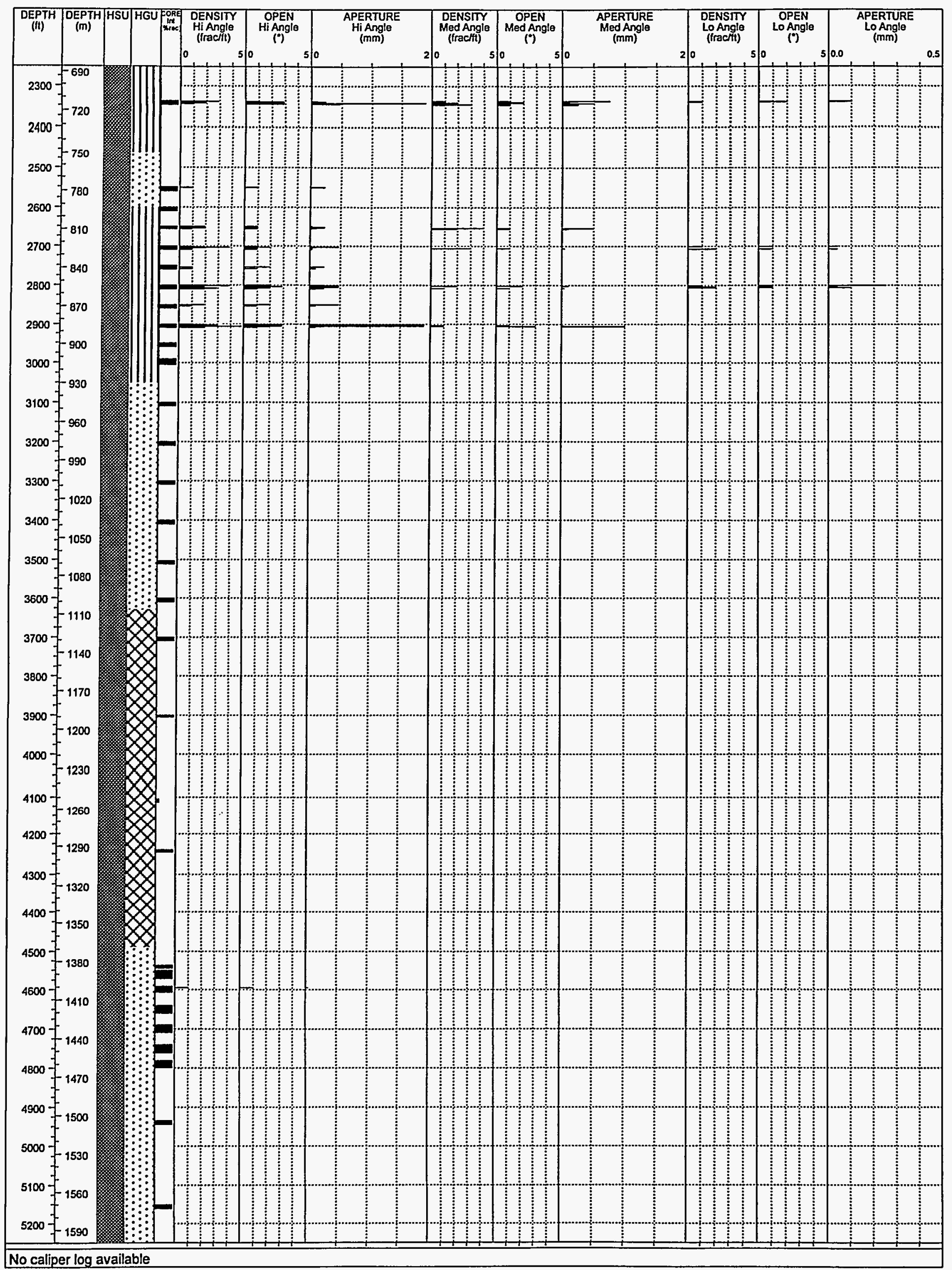


Hydrostratigraphic Unit (HSU)

\begin{tabular}{ll}
\hline Timber Mountain Aquifer (TMA) \\
Bullfog Confining Unit (TCB) \\
Belted Range Aquifer (TBA) \\
\end{tabular}

Hydrogeologic Unit (HGU)

|IIIIIIIIII Welded-tuff oquifer (WTA)

$\times \times \times \times \times \times$ Lova-flow aquifer (LFA)

(VTA)

$\vdots: \vdots: \vdots: \vdots: \vdots:$ Tuff confining unit (TCU)

$$
{ }^{(\circ)} \text { OPEN }
$$

Number

Estimated Range of Percent Openness

$$
\begin{gathered}
0 \% \\
1-10 \% \\
10-50 \% \\
50-90 \% \\
90-99 \% \\
100 \%
\end{gathered}
$$




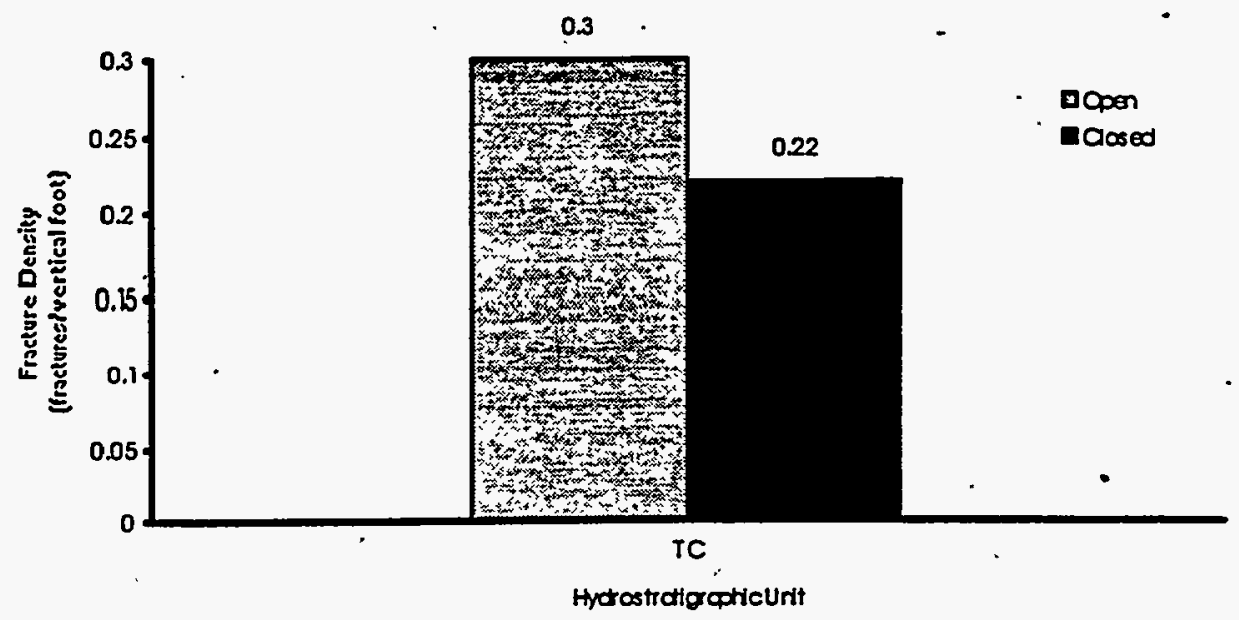

Figure 2-19a

Density of Open and Closed Fractures Relative to Hydrostratigraphy at U-20C/UE-20C

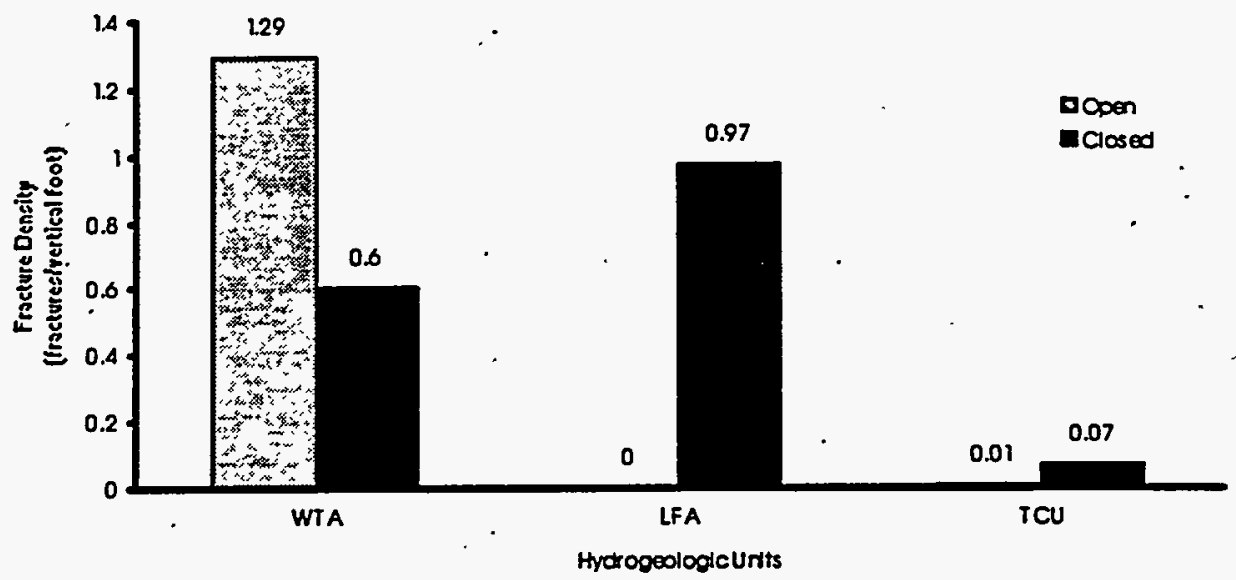

Figure 2-19b

Density of Open and Closed Fractures in Hydrogeologic Units at U-20cUE-20C

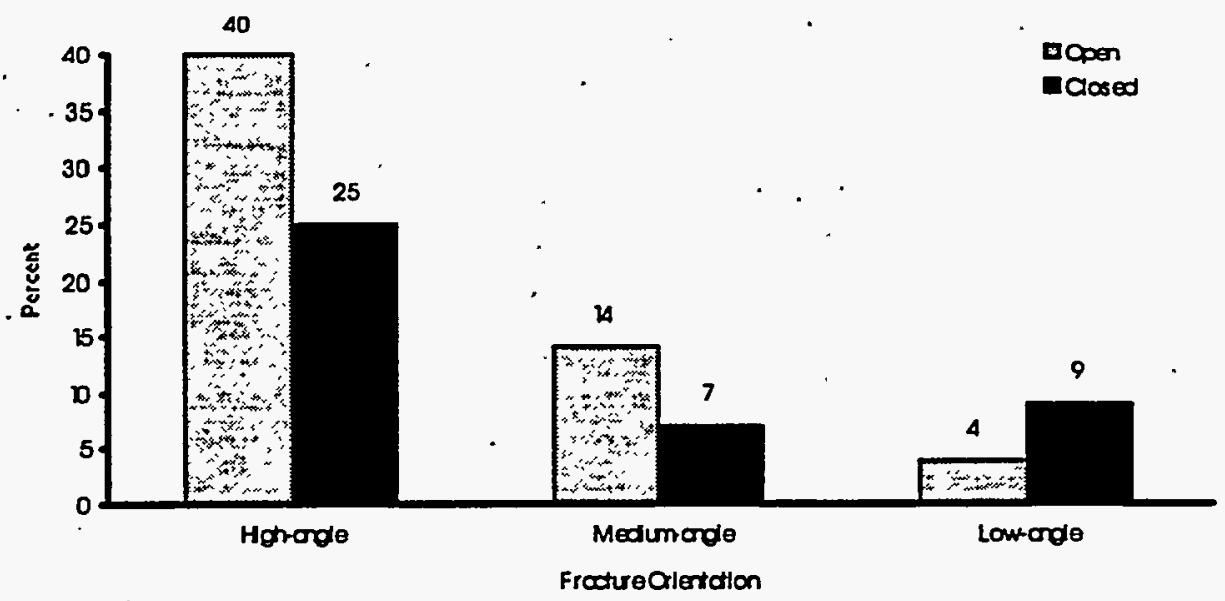

Figure 2-19c

Distribution of Open and Closed Fractures Relative to Orientation at U-20CNE-20C

Figure 2-19a-c

Density and Distribution of Fractures at U-20c/UE-20c 


\section{Density of Open and Closed Fractures in Hydrogeologic Units}

Three HGUs--the WTA, the LFA and the TCU--are represented in the U-20c/UE-20c cores. The density of open fractures is approximately twice that of closed fractures in the WTA. With the exception of two open fractures in the TCU, all other open fractures are in the WTA

(Figure 2-19b).

\section{Distribution of Open and Closed Fractures Relative to Orientation}

In U-20c/UE-20c, the percentages of open and closed fractures are greatest at high-angle orientations. Closed fractures were more abundant than open fractures at low angles

(Figure 2-19c).

\subsubsection{Aperture and Fracture Openness}

Aperture and percent openness of open fractures in the U-20c/UE-20c cores have been analyzed relative to the HGUs and the HSU in which the fractures occur. These relationships are shown in Table 2-6 and discussed below.

Table 2-6

\section{U-20c/UE-20c Fracture Aperture and Percent Open Data}

Data Grouped by Hydrostratigraphic Units

\begin{tabular}{|c|c|c|}
\hline Hydrostratigraphic Units . & $\begin{array}{c}\text { Average Aperture } \\
\text { (millimeters) }\end{array}$ & Percent Open \\
\hline \hline Tuff Cone (TC) & 0.4 & $1-50$ percent $^{1}$ \\
\hline
\end{tabular}

Data Grouped by Hydrogeologic Units

\begin{tabular}{|l|c|c|}
\hline \multicolumn{1}{|c|}{ Hydrogeologic Unit } & $\begin{array}{c}\text { Average Aperture } \\
\text { (millimeters) }\end{array}$ & Percent Open \\
\hline \hline Welded-tuff aquifer (WTA) & 0.4 & $1-50$ percent ${ }^{1 \cdot}$ \\
\hline Lava-flow aquifer (LFA) & $\star^{2}$ & $\star^{2}$ \\
\hline Tuff confining unit (TCU) & 0.1 & $0-10$ percent \\
\hline
\end{tabular}

1 Typical range ( 1 - 50 percent) is presented; however, the data set is skewed toward the low end ( 1 - 10 percent).

$24.6 \mathrm{~m}$ (15 ft) of LFA core logged, but no open fractures observed. 


\section{Aperture and Openness Relative to Hydrostratigraphic Units}

The average aperture for fractures within the TC is $0.4 \mathrm{~mm}(0.02 \mathrm{in}$.) (Table 2-6). Fractures were observed to average $1-50$ percent open.

\section{Aperture and Openness Relative to Hydrogeologic Units}

Apertures for fractures within the WTA average $0.4 \mathrm{~mm}(0.02 \mathrm{in}$.), whereas fractures within the TCU have apertures that average considerably less at $0.1 \mathrm{~mm}(.004 \mathrm{in}$.) (Table 2-Ø). In addition to having a larger average aperture than those within the TCU, fractures within the WTA are also more open, averaging 1 - 50 percent versus 0 - 10 percent for TCU.

\subsubsection{Mineralogy of Fracture Coatings}

\section{Distribution of Fracture-Coating Minerals in Hydrostratigraphic Units}

The distribution of fracture-coating minerals in the TC in the U-20c/UE-20c cores is presented in Figure 2-20a. Fe/Mn oxides and chalcedony are the dominant mineral coatings in the cores, followed closely by clay minerals. Zeolites were conspicuously rare in these cores. Calcite and vapor-phase silicate minerals were observed in very low abundances.

\section{Distribution of Fracture-Coating Minerals in Hydrogeologic Units}

The distribution of fracture-coating minerals in the three HGUs present in the U-20c/UE-20c cores (the WTA, the LFA and the TCU) is presented in Figure 2-20b. Significant differences were found between the dominant mineral coatings in the three HGUs. In the WTA, chalcedony; $\mathrm{Fe} / \mathrm{Mn}$ oxides, and clays are the dominant minerals, occurring in approximately equivalent proportions. In the LFA, calcite is the most abundant fracture-coating mineral, followed by chalcedony and Fe/Mn oxides in equal abundances. In fractures in the TCU, zeolites are the dominant mineral, with $\mathrm{Fe} / \mathrm{Mn}$ oxides and chalcedony also abundant.

\subsubsection{Fracture Data Comparisons with Available Hydrologic Test Data}

Injection and swabbing tests were conducted in the 24.4-cm (9 5/8-in) diameter center-punched hole between 1,390 to $1,463 \mathrm{~m}$ (4,560 to $4,800 \mathrm{ft}$ ) depth. These data indicate that the interval has a very low relative specific capacity, on the order of 0.002 gallons per minute (gpm) per foot of drawdown (Blankennagel and Weir, 1966). This is consistent with its zeolitized bedded tuff lithology and its TCU assignment. Low fracture density (only one open fracture logged) and other attributes obtained from the cores recovered over the test interval are also consistent with 

q0Z-Z बanbi]

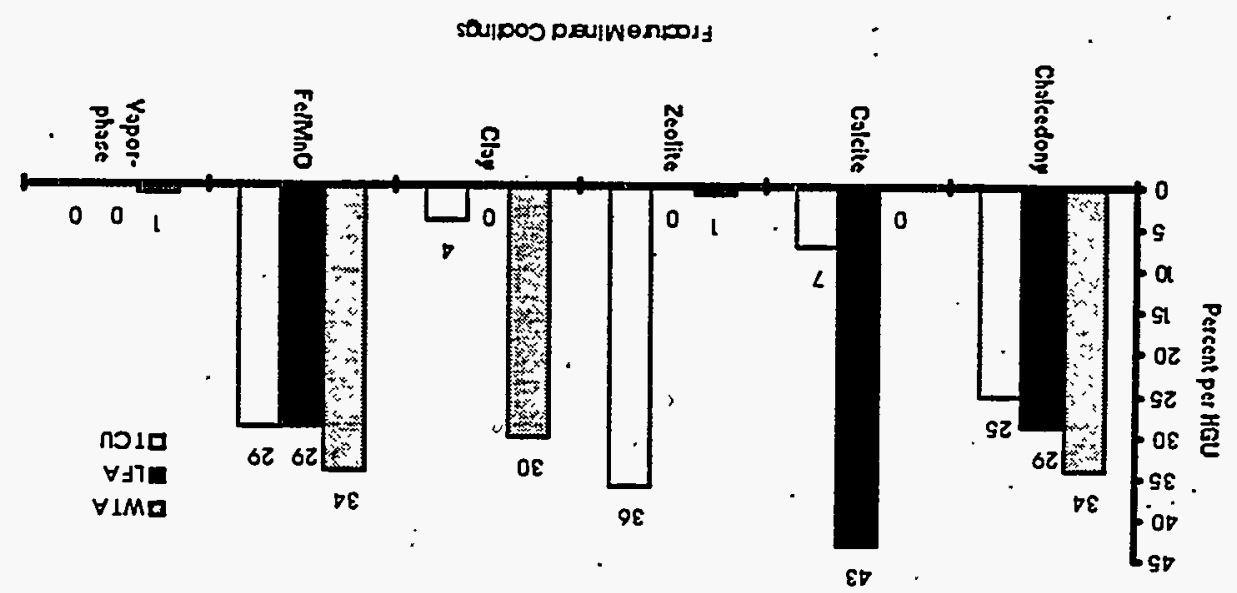

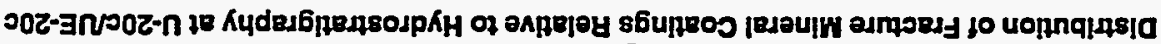
Boz-z ean6ly

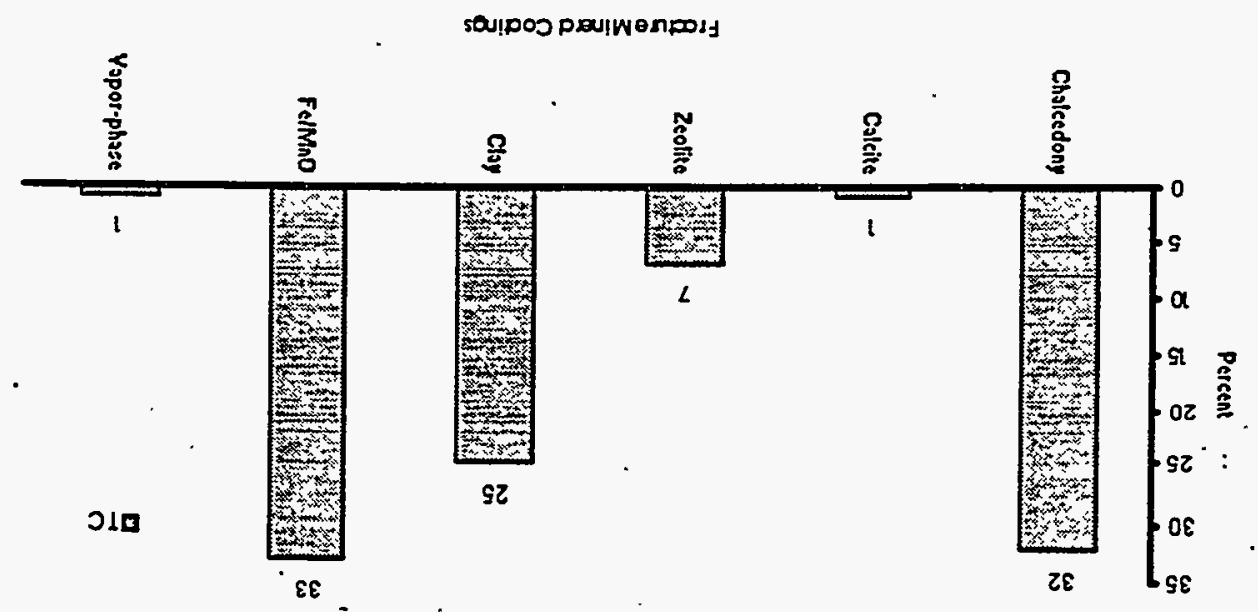


the apparently poor hydraulic properties (Figure 2-21). No caliper log is available for the centerpunched portion of the borehole in which the hydrologic tests were conducted.

\subsection{Exploratory Hole UE-20f}

\subsubsection{Hole History}

The UE-20f drill hole is located on Pahute Mesa in central Area 20 of the NTS at an elevation of $1,864.2 \mathrm{~m}(6,116 \mathrm{ft}$ ) (Figure 1-1). The hole was drilled in 1964 to a TD of 4,171.5 $\mathrm{m}(13,686 \mathrm{ft})$ as part of a program to explore individual sites on Pahute Mesa prior to drilling emplacement holes (Carroll, 1966). UE-20f is currently the deepest drill hole on the NTS and the intermittent cores that were cut during the drilling operation provide valuable lithologic and fracture information. Table $\mathrm{C}-19$ in Appendix $\mathrm{C}$ is an abridged summary of the drill-hole statistics for UE-20f, and Table C-20 in Appendix C includes the core intervals.

\subsubsection{Hydrogeology}

Exploratory hole.UE-20f is located in a north-south trending-structural block within the buried, Silent Canyon caldera complex. The structural block is bound on the west side by the highangle, west-dipping Purse fault and on the east side by the West Boxcar fault that has similar structural kinematics. The surface geology in the area includes nearly horizontal, volcanic strata of the Trail Ridge Tuff (Ekren et al., 1966).

This structural block is also included in the Western Area 20 structural block (Warren, 1994). Six HSUs are associated with this block and include the TMA, TC, TCB, TBA, BCU, and BAQ. Only the following five HSUs were encountered in the UE-20f drill hole. The HSUs are:

- TMA from the surface to $752.9 \mathrm{~m}(2,470 \mathrm{ft})$ depth, which includes bedded tuff and nonwelded to densely welded ash-flow tuff of the Thirsty Canyon Group and Timber Mountain Group

- TC from $752.9 \mathrm{~m}(2,470 \mathrm{ft})$ to $1,859.3 \mathrm{~m}(6,100 \mathrm{ft})$, which consists of lava flows, flow breccia, bedded tuff, and nonwelded to densely welded ash-flow tuff of the Paintbrush Group, Volcanics of Area 20, and the Crater Flat Group

- TCB from $1,859.3 \mathrm{~m}(6,100 \mathrm{ft})$ to $2,521.6 \mathrm{~m}(8,273 \mathrm{ft})$, which include the zeolitized, nonwelded ash-flow tuff of the mafic-poor, lithic-rich Bullfrog Tuff (Crater Flat Group) 
This page intentionally left blank. 


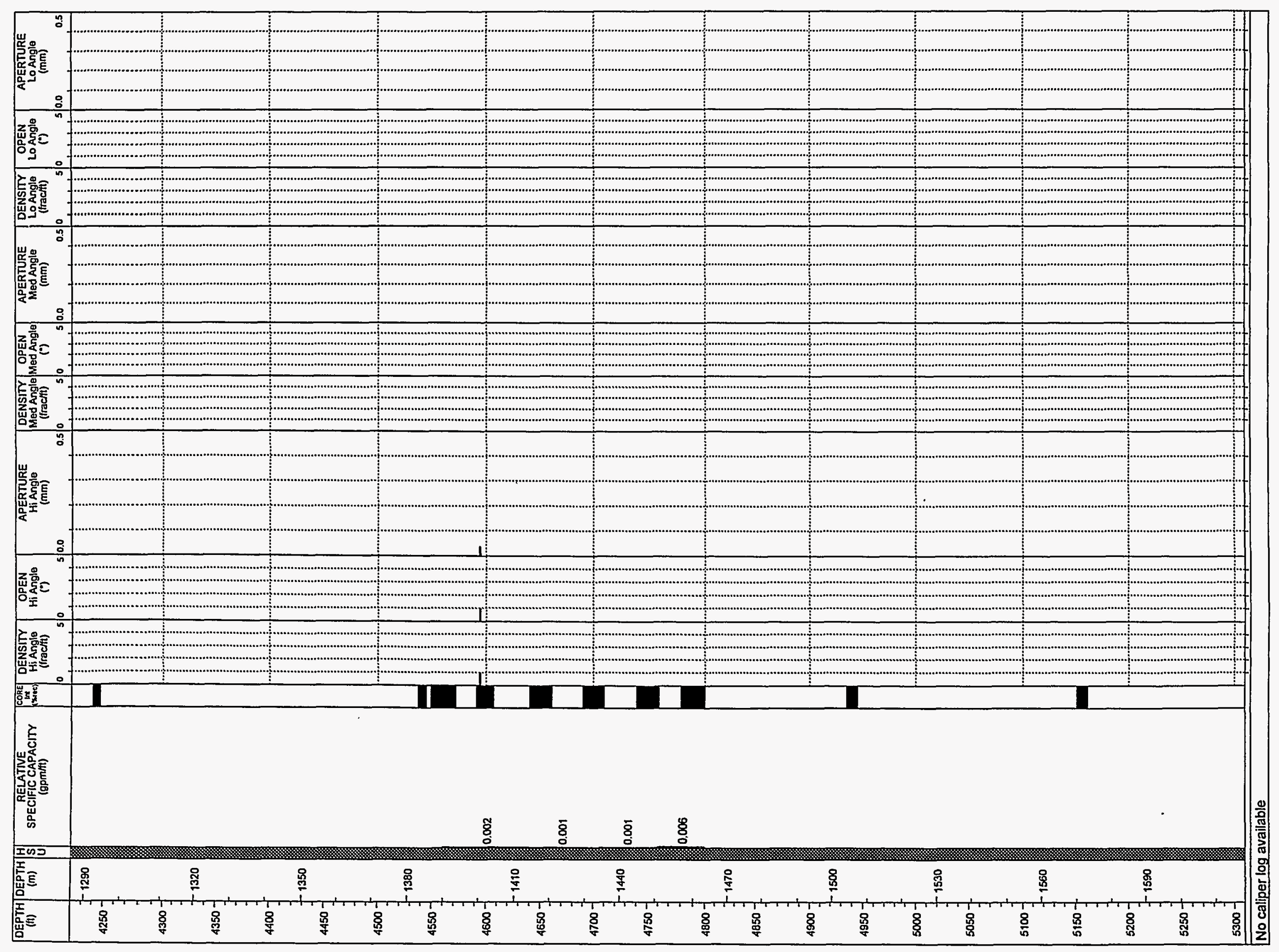


LEGEND

Hydrostratigrophic Unit (HSU)

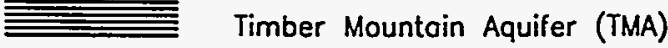

Tuff Cone (TC)

Bullfrog Confining Unit (TCB)

Belted Range Aquifer (TBA)

Bosol Aquifer (BAQ)

$$
{ }^{(0)} \text { OPEN }
$$

Number

Estimated Range of Percent Openness

0

$.0 \%$

$1-10 \%$

$10-50 \%$

$50-90 \%$

$90-99 \%$

$100 \%$

Figure 2-21

UE-20c: Composite Log of Hydrologic Test Data and Fracture Data,

1,286.3 - 1,618.5 Meters 
- TBA from 2,521.6 m (8,273 ft) to 3,378.7 m (11,085 ft), which consists of lava flows, flow breccia, and nonwelded to densely welded ash-flow tuff of the Belted Range Group and Volcanics of Big Dome

- $\mathrm{BAQ}$ from $3,378.7 \mathrm{~m}(11,085 \mathrm{ft})$ to $\mathrm{TD}$, which includes lava flows and nonwelded to moderately welded ash-flow tuff of the Volcanics of Oak Spring Butte.

The lithologic characteristics that define the remaining HSU for this block, the BCU, were not encountered in the deepest stratigraphic interval of UE-20f, thus, precluding characterization. The condensed lithologic and stratigraphic log for the hole are outlined in Table C-21 in Appendix C.

The UE-20f drill hole was included in the fracture study to examine the HSUs present at depth in the caldera complex (TCB and BAQ). Additional data were collected from the TC and TBA to expand their respective datasets.

Hydrologic tests conducted in UE-20f are discussed in Section 2.7.4. The static water level was recorded at $595.6 \mathrm{~m}(1,954 \mathrm{ft})$.

\subsubsection{Fracture Analysis}

\subsubsection{Density and Distribution}

The density of fractures in the core sections from UE-20f has been analyzed relative to occurrence within various HSUs and HGUs, and relative to fracture orientation. In these analyses, the distribution of fractures has been examined separately for open and closed fractures. These relationships are shown in Figures 2-22, 2-23, and 2-24a-c and discussed in the following text.

\section{Vertical Distribution of Open and Closed Fractures}

Figures 2-22 and 2-23 show the core intervals examined and the vertical distribution of open fractures in the UE-20f core. The figures also present data on the aperture, openness, and density of fractures at high, medium, and low angles. The figures also show the relationship of fracture density and the caliper log. 
This page intentionally left blank. 


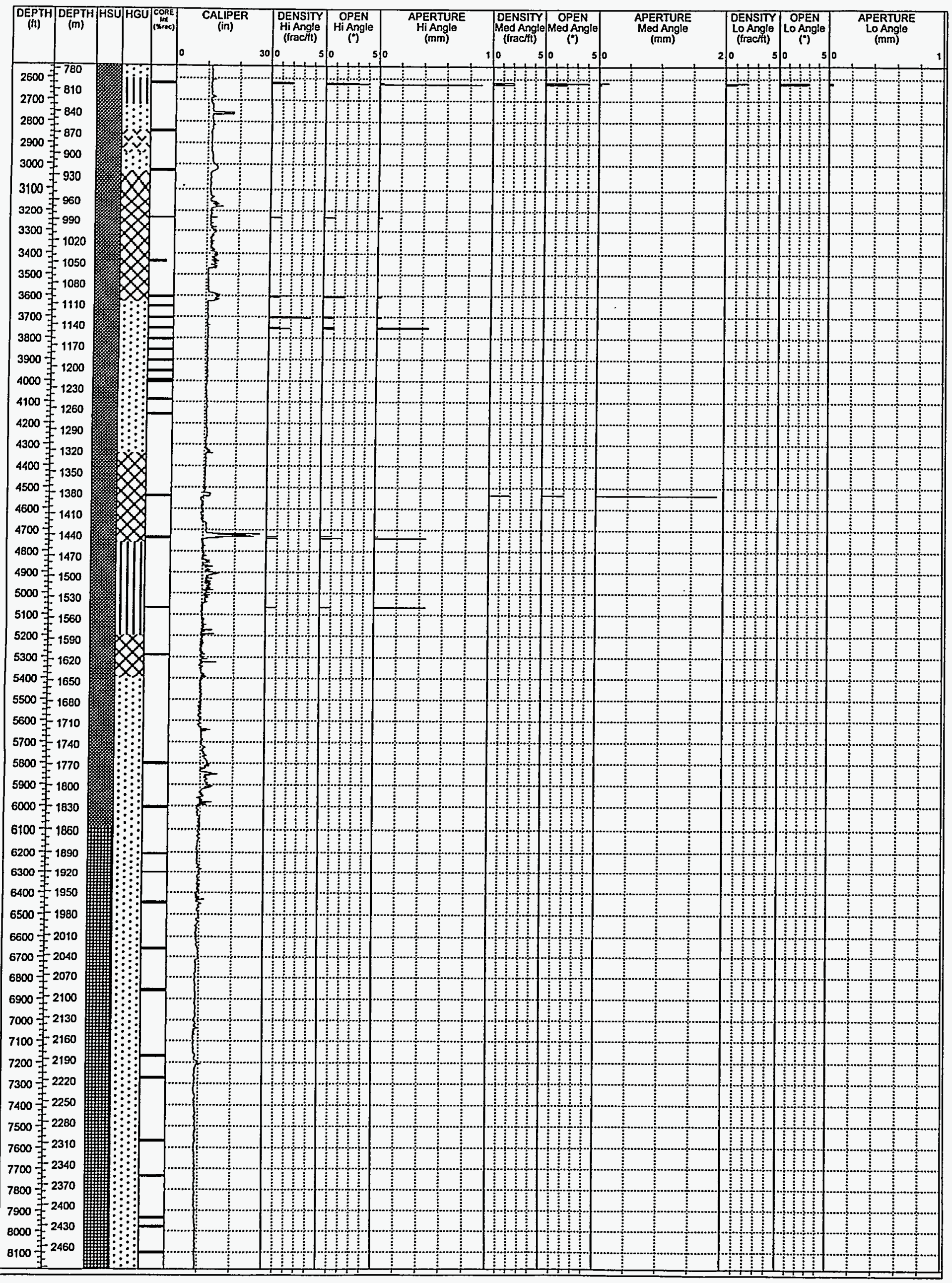




\section{LEGEND}

Hydrostrotigrophic Unit (HSU)

\begin{tabular}{|c|c|}
\hline 要紧 & Timber Mountoin Aquifer (TMA) \\
\hline & Tuff Cone (TC) \\
\hline 盎 & Bullfrog Confining Unit (TCB) \\
\hline 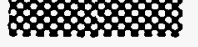 & Belted Ronge Aquifer (TBA) \\
\hline 等 & Bosol Aquifer (BAQ) \\
\hline Hydrogeologi & Unit (HGU) \\
\hline\|\|$\| M$ & Welded-tuff aquifer (WTA) \\
\hline$x \times x \times x$ & Lava-flow oquifer (LFA) \\
\hline 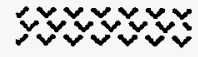 & Vitric-tuff oquifer (VTA) \\
\hline$\vdots: \vdots: \vdots \vdots \vdots$ & Tuff confining unit (TCU) \\
\hline & (for ofl angles) \\
\hline
\end{tabular}

Number

0

1

2

3

4

5

\section{Estimated Range of Percent Openness}

$0 \%$

$$
\begin{gathered}
1-10 \% \\
10-50 \% \\
50-90 \% \\
90-99 \% \\
100 \%
\end{gathered}
$$

Figure 2-22

UE-20f: Composite Log of Open Fracture Dafa, 774.2 - 2,493.3 Meters 


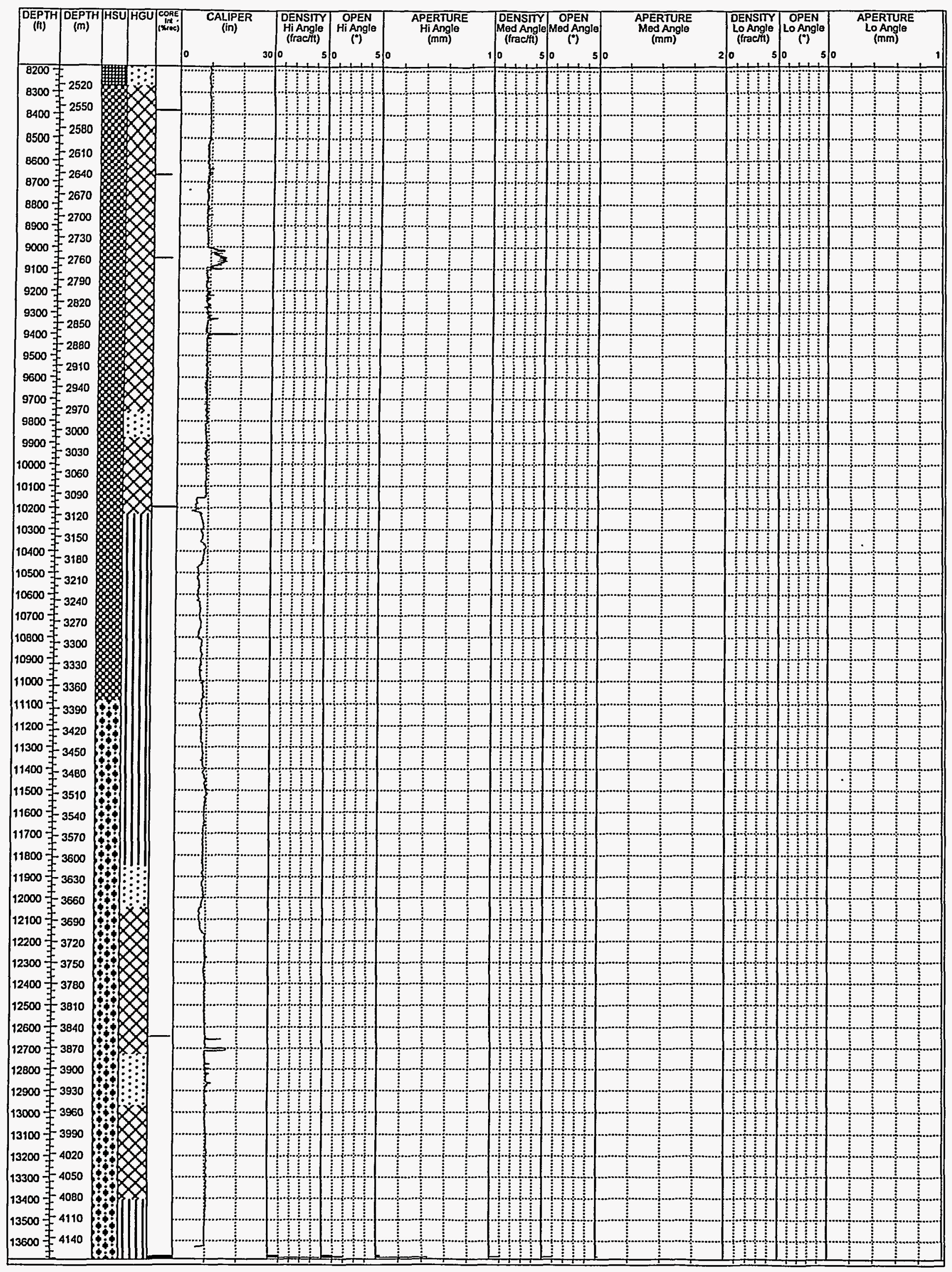


LEGEND

Hydrostratigraphic Unit (HSU)

\begin{tabular}{|c|c|}
\hline 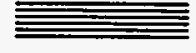 & Timber Mountain-Aquifer (TMA) \\
\hline 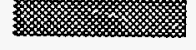 & Tuff Cone (TC) \\
\hline 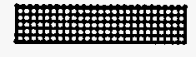 & Bullfrog Confining Unit (TCB) \\
\hline mosoms & Belted Range Aquifer (TBA) \\
\hline 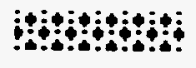 & Bosal Aquifer (BAQ) \\
\hline \multicolumn{2}{|c|}{ Hydrogeologic Unit (HGU) } \\
\hline |l|||||||||||| & Welded-tuff aquifer (WTA) \\
\hline$\triangle X X X X X X$ & Lovo-flow aquifer (LFA) \\
\hline 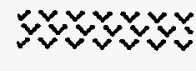 & Vitric-tuff aquifer (VTA) \\
\hline 品: & Tuff confining unit (TCU) \\
\hline & (for all ongles) \\
\hline
\end{tabular}

\begin{tabular}{cc} 
Number & Estimated Ronge of Percent Openness \\
\hline 0 & $0 \%$ \\
1 & $1-10 \%$ \\
2 & $10-50 \%$ \\
3 & $50-90 \%$ \\
4 & $90-99 \%$ \\
5 & $100 \%$
\end{tabular}

Figure 2-23 


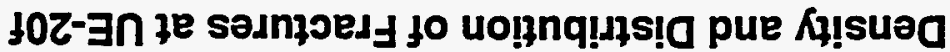

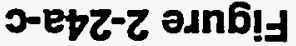

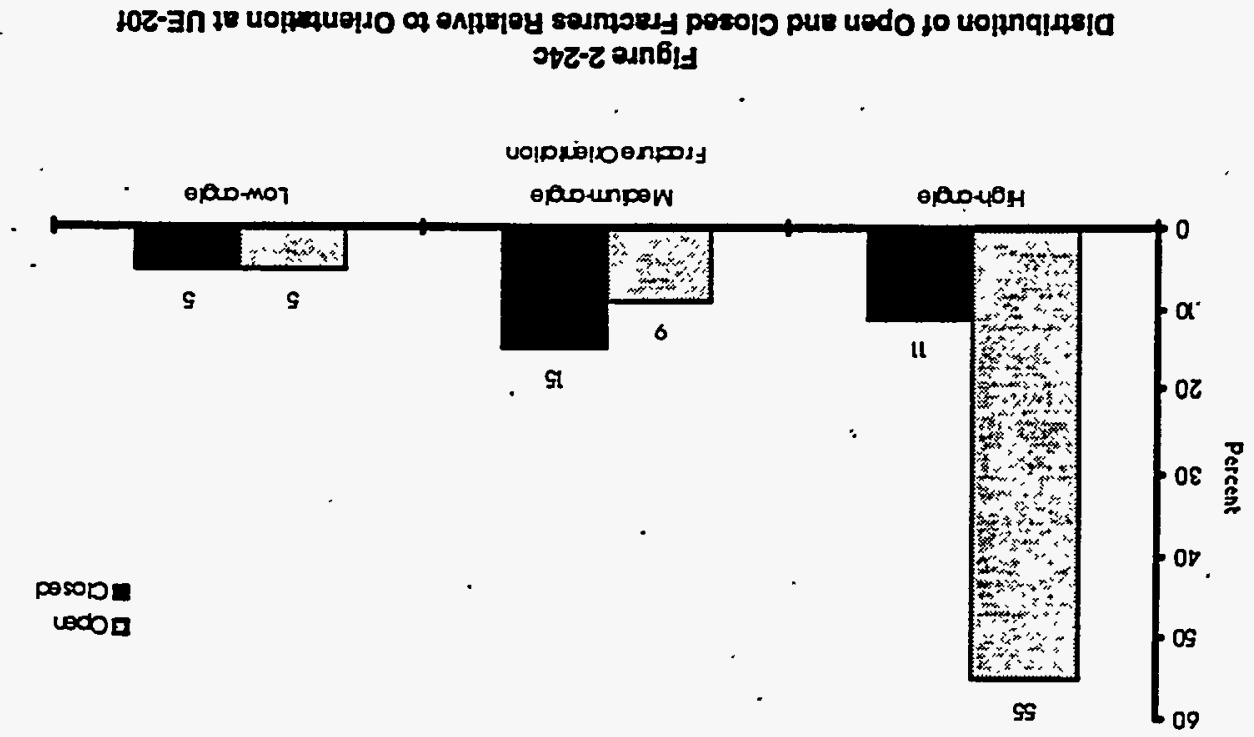

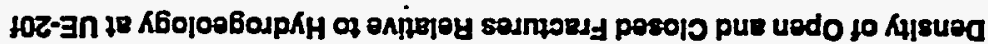
qbz-Z edn6its

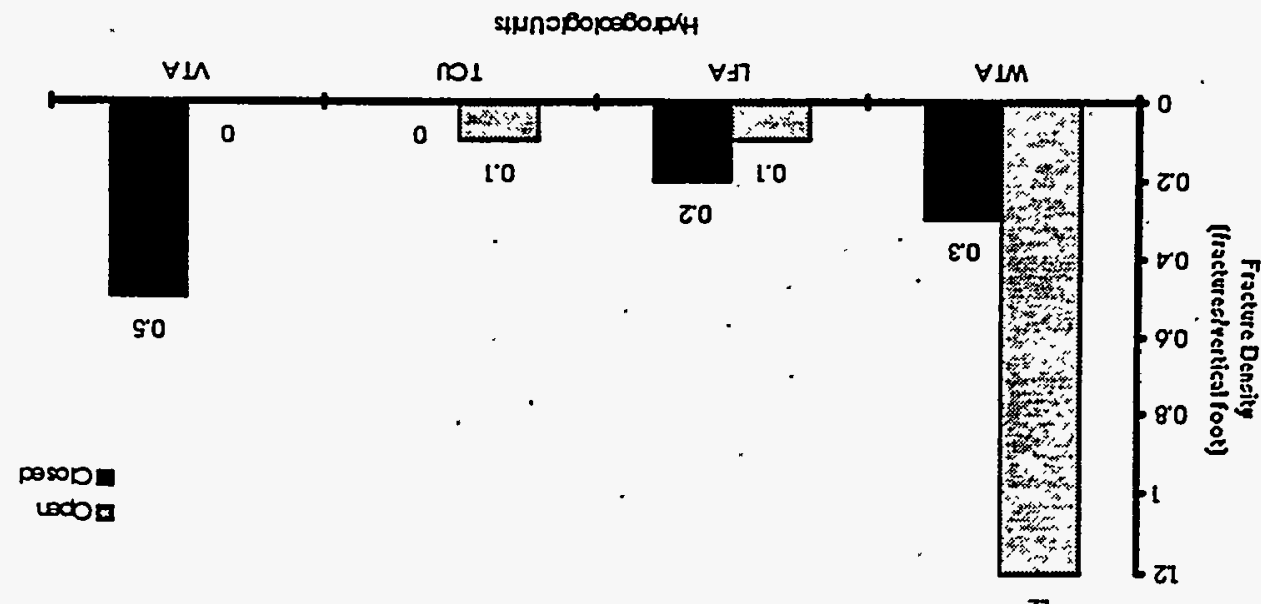

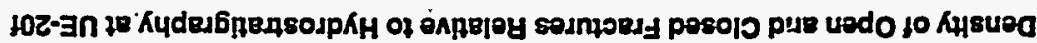

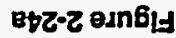

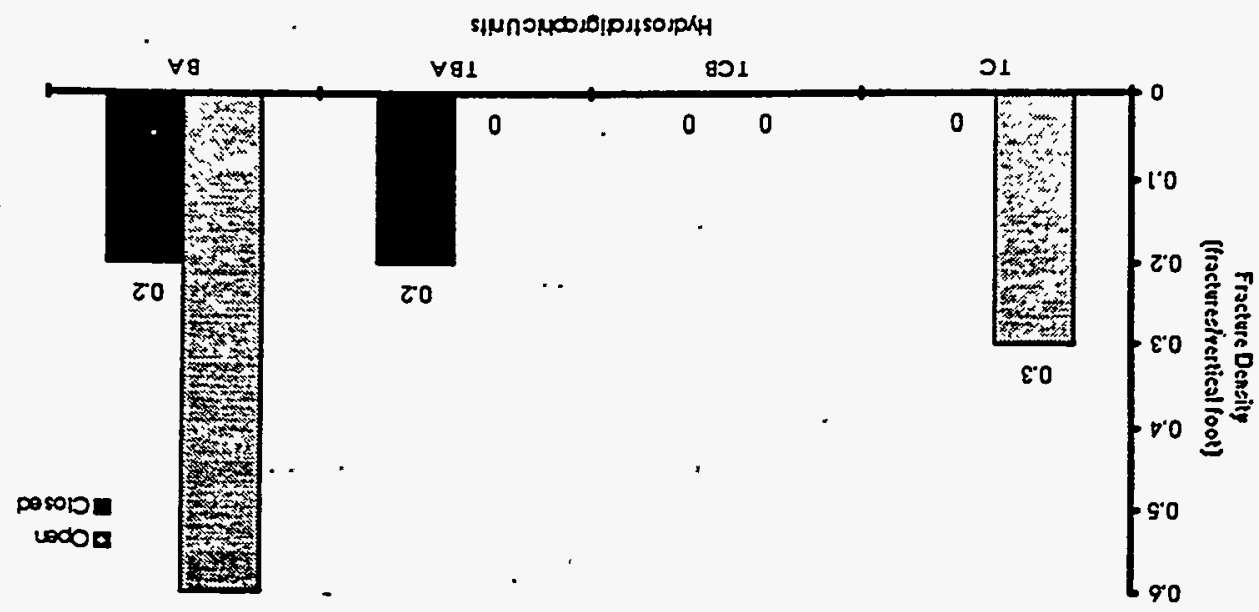




\section{Density of Open and Closed Fractures in Hydrostratigraphic Units}

The five HSUs represented in the cored strata in Exploratory Hole UE-20f are the TMA, the TC, the TBA, the TCB, and the BAQ. Fractures were analyzed in all HSUs except the TMA. In the $T C$, all observed fractures were open, whereas in the TBA, all observed fractures were closed: In the $\mathrm{BAQ}$, the density of open fractures is three times that of closed fractures. No fractures were observed in the TCB (Figure 2-24a).

\section{Density of Open and Closed Fractures in Hydrogeologic Units}

Four HGUs (the WTA, the LFA, the TCU, and the VTA) are represented in the UE-20f cores. The greatest density of fractures occurs in the WTA, where open fractures are approximately four times more abundant than closed fractures. Closed fractures are twice as abundant as open fractures in the LFA. All fractures observed in the TCU were open, while all fractures in the VTA were closed (Figure 2-24b).

\section{Distribution of Open and Closed Fractures Relative to Orientation}

In the UE-20f core, the percentage of open fractures is greatest at high-angle orientations. Fiftyfive percent of all observed fractures in the core are high-angle open fractures. The percentage of closed fractures is greatest at medium orientations (Figure 2-24c).

\subsubsection{Aperture and Fracture Openness}

Aperture and percent openness of open fractures in the UE-20f cores have been analyzed relative to the HGUs and HSUs in which the fractures occur. These relationships are shown in Table 2-7 and in the following text.

\section{Aperture and Openness Relative to Hydrostratigraphic. Units}

Fractures within the BAQ have the largest apertures observed averaging $0.3 \mathrm{~mm}(0.01 \mathrm{in}$.) (Table 2-7). Average apertures of fractures within the TC were observed to be somewhat less, at $0.2 \mathrm{~mm}(0.008 \mathrm{in}$.). Fractures within both of these HSUs average $0-10$ percent open. No open fractures were observed within the TCB and TBA. 
Table 2-7

UE-20f Fracture Aperture and Percent Open Data

Data Grouped by Hydrostratigraphic Units

\begin{tabular}{|l|c|c||}
\hline \multicolumn{1}{|c|}{ Hydrostratigraphic Units } & $\begin{array}{c}\text { Average Aperture } \\
\text { (millimeters) }\end{array}$ & Percent Open \\
\hline \hline Tuff Cone (TC) & 0.2 & $1-10$ percent $^{1}$ \\
\hline Bullfrog Confining Unit (TCB) & $\star^{2}$ & $\star^{2}$ \\
\hline Belted Range Aquifer (TBA) & $\star^{3}$ & $1-10$ percent \\
\hline Basal Aquifer (BAQ) & 0.3 & $\star^{3}$ \\
\hline
\end{tabular}

Data Grouped by Hydrogeologic Units

\begin{tabular}{|l|c|c|}
\hline \multicolumn{1}{|c|}{ Hydrogeologic Unit } & $\begin{array}{c}\text { Average Aperture } \\
\text { (millimeters) }\end{array}$ & Percent Open \\
\hline \hline Vitric-tuff aquifer (VTA) & & \\
\hline Welded-tuff aquifer (WTA) & 0.2 & $50-99$ percent \\
\hline Lava-flow aquifer (LFA) & 0.5 & $1-50$ percent \\
\hline Tuff confining unit (TCU) & 0.1 & $1-10$ percent \\
\hline
\end{tabular}

1 The 1 - 10 percent open category was most commonly observed; however, the data spans the full range of.1 - 99 percent open.

$233.2 \mathrm{~m}$ (109 ft) of TCB logged, but no open fractures observed.

$34.0 \mathrm{~m}$ (13 ft) of TBA logged, but no open fractures observed.

$43 \mathrm{~m}$ (10 ft) of VTA core logged, but no open fractures observed.

\section{Aperture and Openness Relative to Hydrogeologic Units.}

Fractures within the LFA have the largest average apertures observed at $0.5 \mathrm{~mm}(0.02 \mathrm{in}$.)

(Table 2-7). Average apertures of fractures in the WTA are considerably less at $0.2 \mathrm{~mm}$ (0.008 in.). However, fractures appeared more open in the WTA averaging $50-99$ percent open versus $1-50$ percent open for LFA. The TCU had the smallest apertures, averaging $0.1 \mathrm{~mm}$ (0.004 in.), as well as the least percent open, at $1-10$ percent.

\subsubsection{Mineralogy of Fracture Coatings}

\section{Distribution of Fracture-Coating Minerals in Hydrostratigraphic Units}

The distribution of fracture-coating minerals in the four HSUs represented in the UE-20f core is presented in Figure 2-25a. Overall, zeolites and Fe/Mn oxides are the most important fracturelining minerals in the core, but significant differences exist between the dominant mineral coatings in the different HSUs. In the TC, zeolites and Fe/Mn oxides are the dominant mineral coatings, with chalcedony, quartz, calcite, clay, vapor-phase silicates, and fault gouge also 


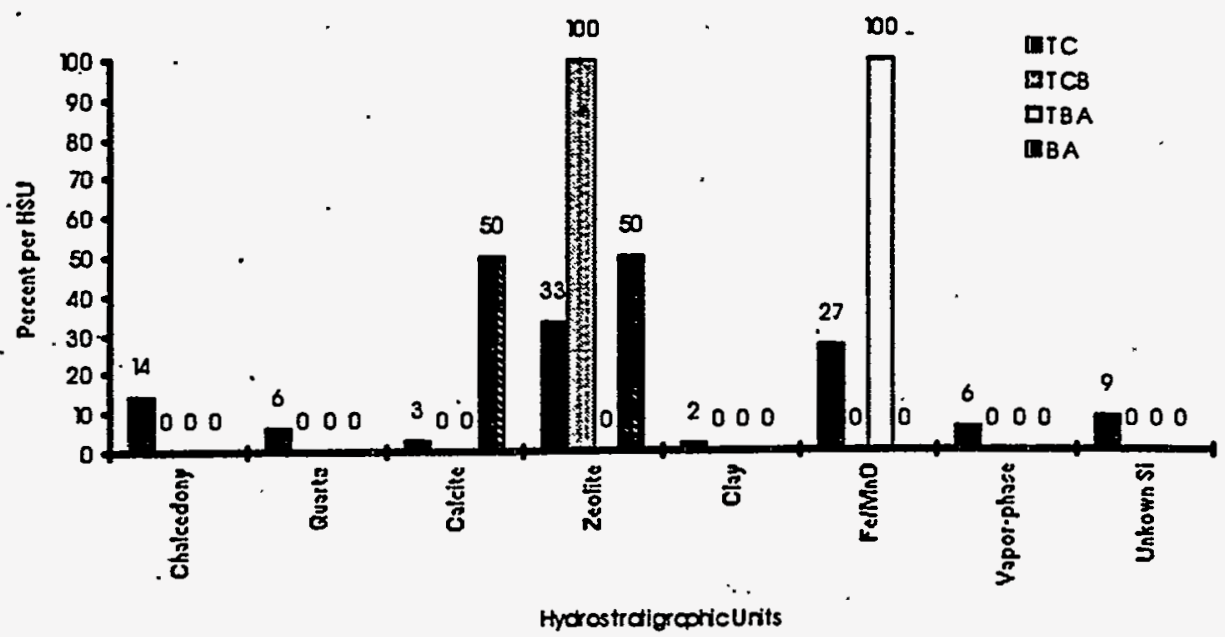

Figure 2-25a

Distribution of Fracture Mineral Coatings Relative to Hydrostratigraphy at UE-20f

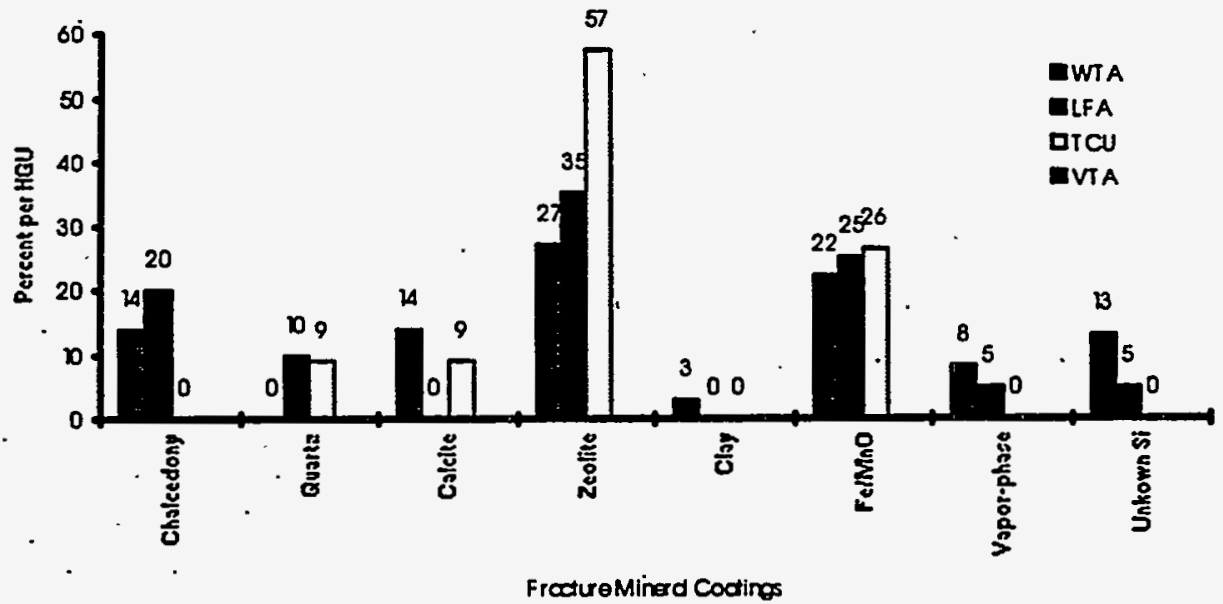

Figure 2-25b

Distribution of Fracture Mineral Coatings Relative to Hydrogeology at UE-20f

Figure 2-25a-b

Distribution of Fracture Mineral Coatings at UE-20f 
present. In contrast, all fractures in the TCB are coated or filled with zeolites; no other mineral coatings were observed. In the TBA, all fractures were coated or filled with Fe/Mn oxides. In the $\mathrm{BAQ}$, fractures were coated with calcite and/or zeolites', in equivalent abundances.

\section{Distribution of Fracture-Coating Minerals in Hydrogeologic Units}

The distribution of fracture-coating minerals in the four HGUs represented in the UE-20f cores is presented in Figure 2-25b. In the WTÁ, the LFA, and the TCU, zeolites and Fe/Mn oxides are the most common mineral coatings. In the WTA, chalcedony, calcite, and fault gouge are also important. In the LFA, chalcedony and quartz are fairly abundant fracture-coating minerals.

\subsubsection{Comparison of Fracture Data, Available Hydrologic Test Data, and Caliper Log}

Hydrologic testing was conducted in UE-20f in 1964 to determine the water yielding potential of the volcanic rock and to ascertain whether the site is suitable for an emplacement hole (Blankennagel et al., 1964). The tests were intentionally limited to the low permeability zones within the first $2,795 \mathrm{~m}(9,170 \mathrm{ft})$ of the hole. Figure $2-26$ presents the hydrologic test intervals and test data as they compare to the fracture data and caliper log.

When the hydrologic data from the test intervals are compared to the fracture data derived from the analyzed core, only limited qualitative conclusions can be reached. The very small ratio of available core to the hydrologic test interval precludes a useful comparison.

The hydrologic tests included isolating 23 separate, $60.4-\mathrm{m}$ (198-ft) intervals with packers and conducting either injection or swab tests to determine relative specific capacity. The results from the valid tests (19 of the 23 intervals maintained packer integrity) varied from 0.00-0.39 gallons per minute per foot (gpm/ $\mathrm{ft}$ ) with an average of $0.04 \mathrm{gpm} / \mathrm{ft}$ (Blankennagel et al., 1964). Overall, the low relative specific capacities compare favorably with the low fracture densities and low openness recorded in the core associated with the test intervals. Although from a qualitative standpoint the fracture data agree with the hydrologic test data, it is important to note that on the average, core was available for fracture analysis from less than 5 percent of the hydrologic test interval.

The interval with the highest relative specific capacity ( $3.9 \mathrm{gpm} / \mathrm{ft})$ compares favorably with fracture data derived from core and a conspicuous washout indicated on the caliper log

(Figure 2-26). 
This page intentionally left blank. 


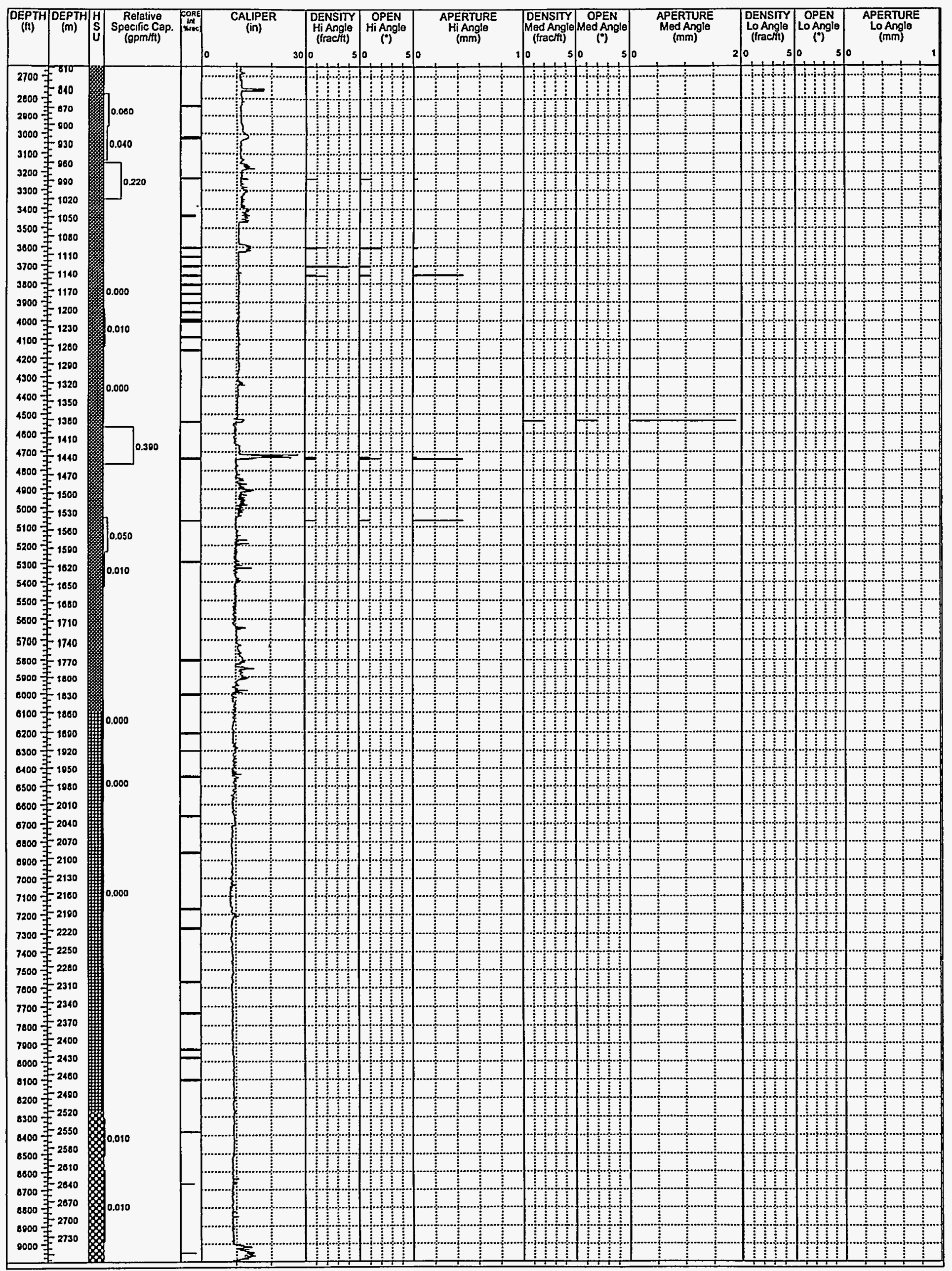


LEGEND

Hydrostroligrophic Unit (HSU)

\begin{tabular}{|c|c|}
\hline 标 & Timber Mountoin Aquifer (TMA) \\
\hline & Tuff Cone (TC) \\
\hline 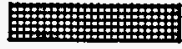 & Bullfrog Confining Unit (TCB) \\
\hline 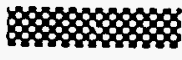 & Belted Range Aquifer (TBA) \\
\hline 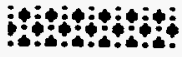 & Basal Aquifer (BAQ) \\
\hline
\end{tabular}

\footnotetext{
(o) OPEN

(for all ongles)
}

\begin{tabular}{cc} 
Number & Estimated Range of Percent Openness \\
\hline 0 & $0 \%$ \\
1 & $1-10 \%$ \\
2 & $10-50 \%$ \\
3 & $50-90 \%$ \\
4 & $90-99 \%$ \\
5 & $100 \%$
\end{tabular}




\subsection{Borehole Image Log Analysis for Selected Drill Holes}

Digital borehole images of both the FMS and BHTV were analyzed for fracture traces using workstation enhancement. Identified planar fracture traces were oriented using proprietary software of the logging vendor. Orientation data are displayed in this report in two formats: 1) lower hemisphere stereographic projections, and 2) rose diagrams of fracture strikes. Trend similarities associated with depth intervals are based on statistical analyses of the data prior to lithologic or stratigraphic comparisons. This was intended to prevent any preconceived biases on the part of the authors from affecting data analysis. Stratigraphy and lithology were factored in later for interpretation and reporting.

The intrinsic nature of the two borehole image logs is such that not all fractures will be imaged. The reasons for this are lack of contrast across fractures (small aperture or completely healed with secondary minerals) and imperfect borehole conditions such as breakouts or washouts. The number of fractures identified in the log data are fewer than those derived from core data. Fracture orientation (in particular, fracture strike), however, is provided by the borehole image logs. Therefore, the emphasis of this section will be fracture orientation rather than fracture density. Fractures have been categorized by level of confidence that the trace actually represents a planar fracture. Only fractures at the highest confidence level were considered.

\subsection{Exploratory Hole UE-18r}

A Schlumberger Formation MicroScanner log was run in the wellbore for the Underground Test Areas Project over the interval $485 \mathrm{~m}$ (1,590 ft) to $1504 \mathrm{~m}(4,937 \mathrm{ft})$, as illustrated in Figure 3-1. The purpose of the image log was to identify and orient natural fractures, and fracture orientations were found to vary with depth and stratigraphic unit. This section of this report is a presentation of the fracture orientations found in Exploratory Hole UE-18r.

\subsubsection{Fracture Orientations}

Orientations of fractures in the depth interval above $609 \mathrm{~m}(2,000 \mathrm{ft})$ in the UE-18r log are shown in Figures 3-1a and $b$. Fractures strike generally east-northeast. The plot of poles to fractures (line perpendicular to fracture plane, Figure 3-1b) show that the fractures are of medium dip, approximately 40 degrees to 60 degrees. None of the fractures are vertical. The figure also indicates both north and south-dipping fractures with the north-dipping fractures being more common. 


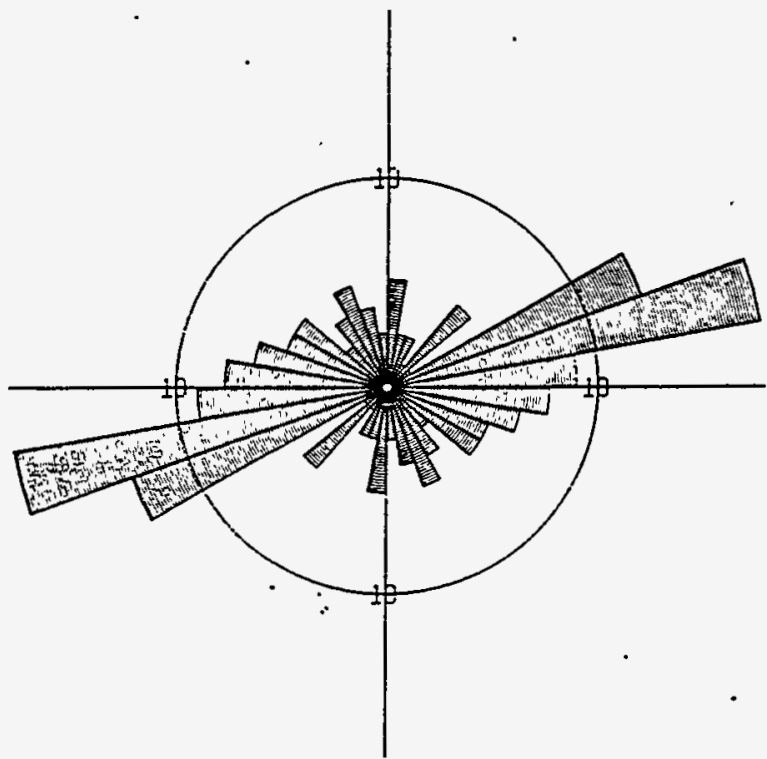

Figure 3-1a

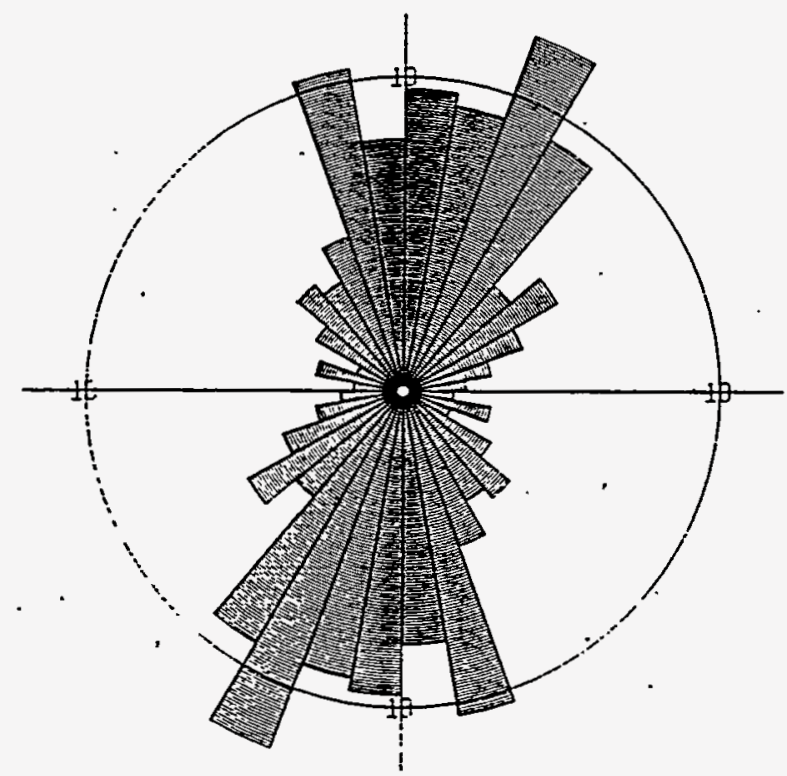

Figure 3-1c

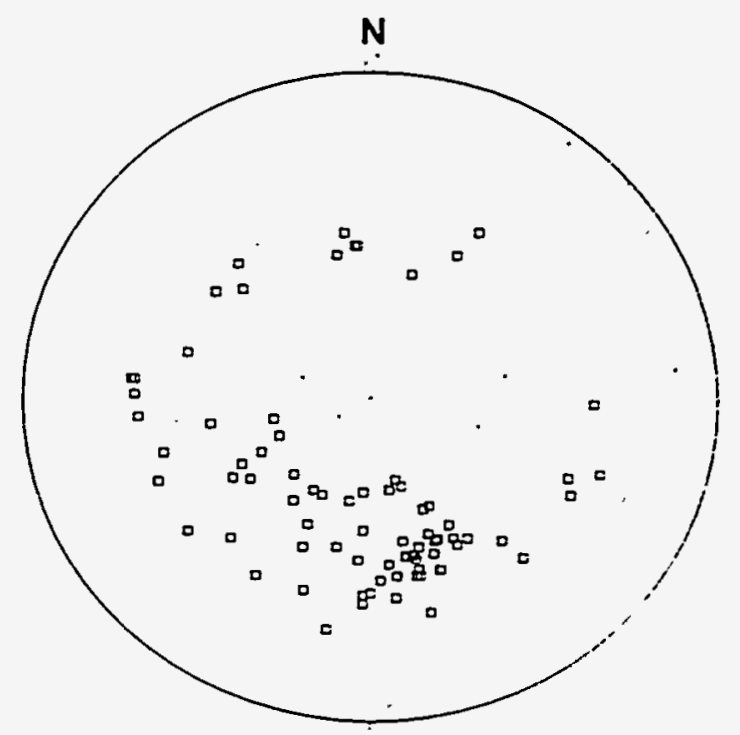

Figure 3-1b

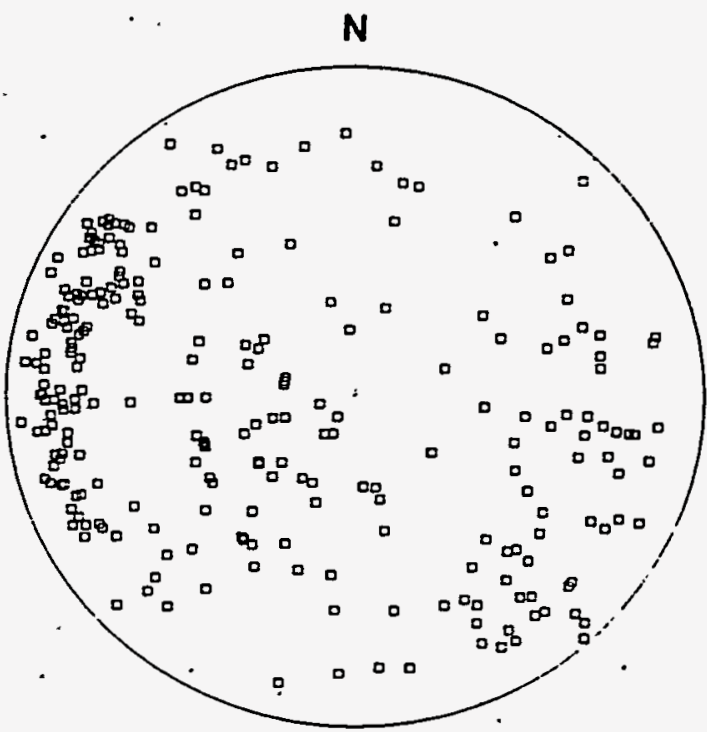

Figure 3-1d

Rose diagram petal lengths are percent of total data points in a 10-degree azimuth interval. Stereographic projections are equal area, lower hemisphere projections of poles to fracture planes. North is at the top of each figure.

3-1 $a$ and $b$ - Depth interval 485 meters $(m)(1,590$ feet [ $f t])$ to $609 \mathrm{~m}(2,000 \mathrm{ft}), 78$ points 3-1 $\mathrm{c}$ and $\mathrm{d}$ - Depth interval $609 \mathrm{~m}(2,000 \mathrm{ft})$ to $1,097 \mathrm{~m}(3,600 \mathrm{ft}), 250$ points

Figure 3-1a-d 


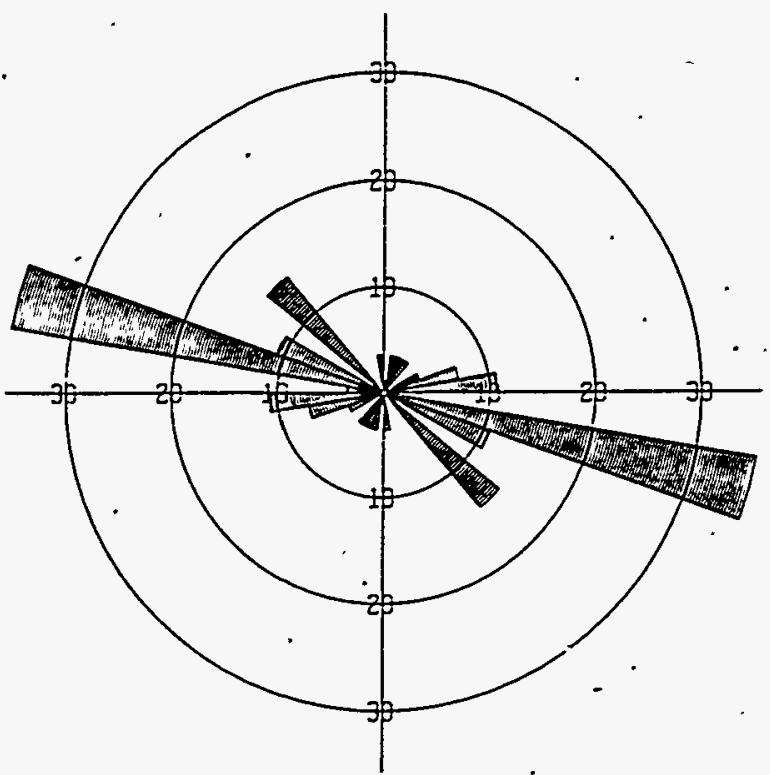

Figure 3-1e

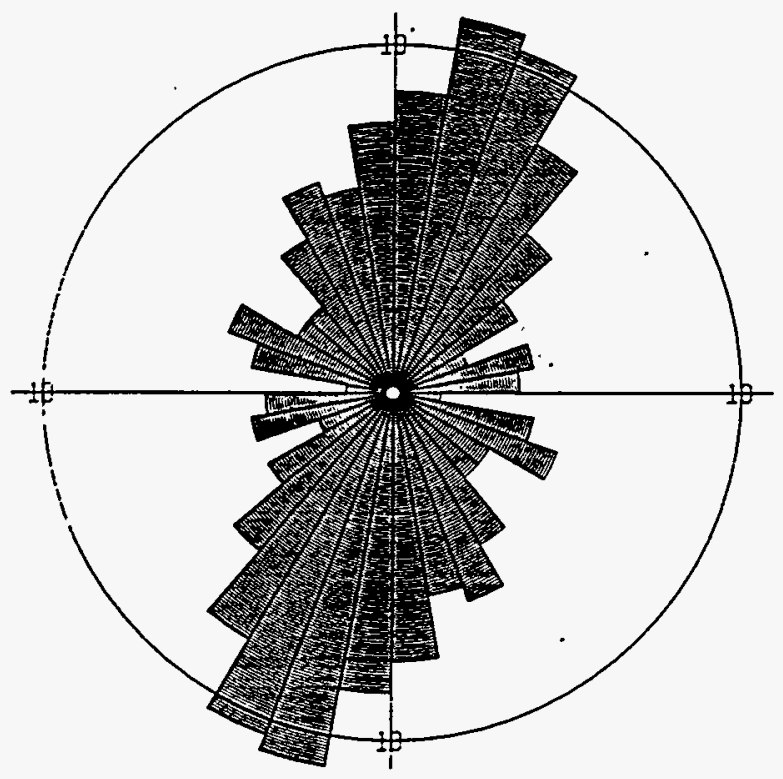

Figure 3-1g

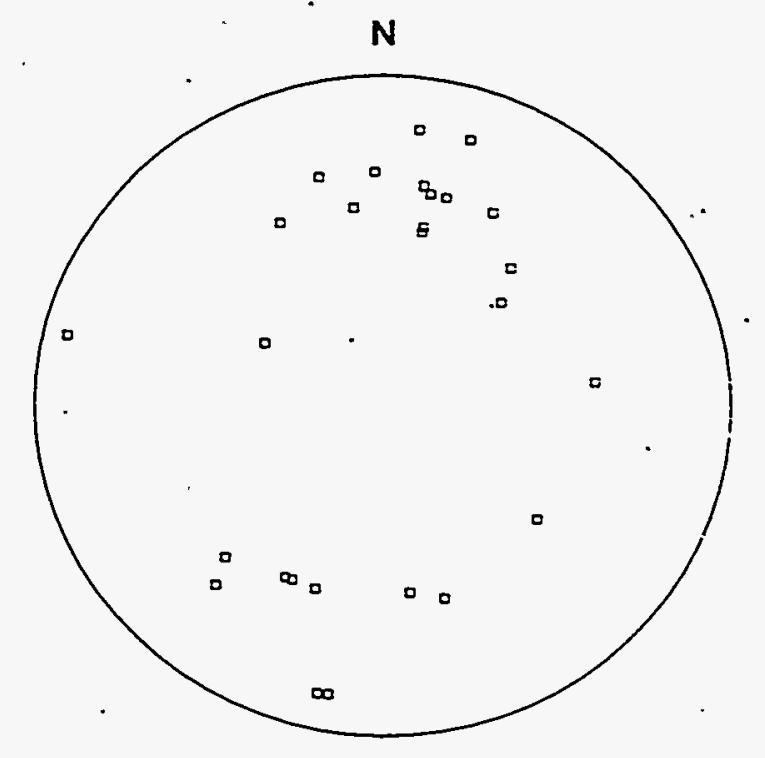

Figure $3-1 f^{*}$

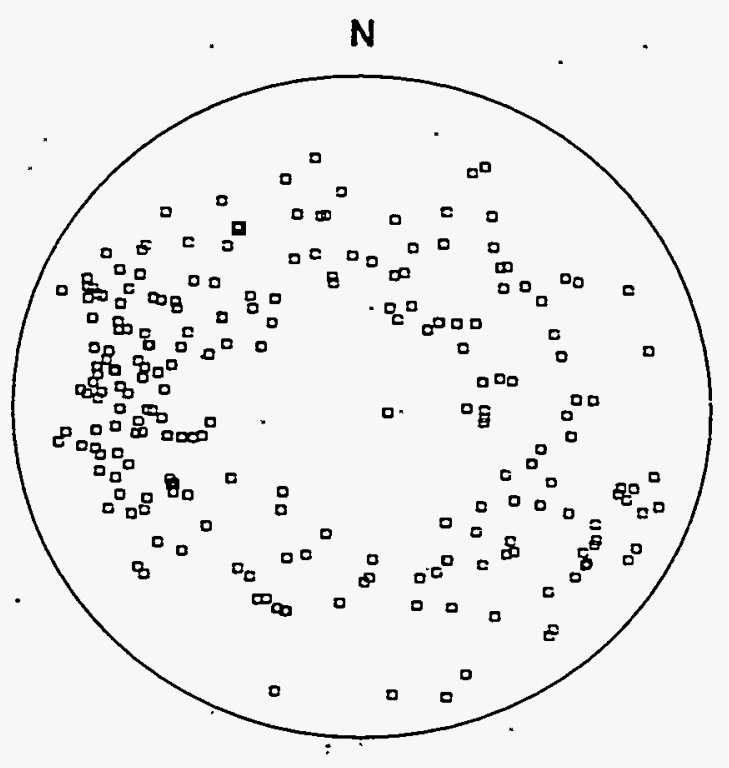

Figure 3-1h

3-1 e and $f$ - Depth interval $1,097 \mathrm{~m}(3,600 \mathrm{ft})$ to $1,188 \mathrm{~m}(3,900 \mathrm{ft}), 28$ points

3-1 $\mathrm{g}$ and $\mathrm{h}$ - Depth interval 1,188 $\mathrm{m}(3,900 \mathrm{ft})$ to $1,504 \mathrm{~m}$ (4,937 ft), 220 points

Figure 3-1e-h

Diagrams Showing Fracture Orientations in

Exploratory Hole UE-18r by Depth Interval (Page 2 of 2)

$3-3$ 
Orientations of fractures in the depth interval of $609 \mathrm{~m}$ to $1,097 \mathrm{~m}$ (2,000 to 3,600 ft) are shown in Figures 3-1c and 3-1d. Fractures in this interval have distinctly different orientation than

- those mentioned above. Fractures in this interval, in general, strike north-northeast, although there is significant scatter in strikes. Poles to fractures, shown in Figure 3-Id, illustrate that these fractures have steeper dips than those previously mentioned. The poles also show that fractures dip both toward the east-southeast and west-northwest.

Fractures in the depth interval of $1,097 \mathrm{~m}$ to $1,188 \mathrm{~m}$ (3,600 to $3,900 \mathrm{ft}$ ) have a unique orientation for the drill hole. The fairly small population of fractures in this short interval strike mostly west-northwest. These strike orientations are shown in Figure 3-1e. Figure 3-1f shows that these fractures dip steeply both toward the north and toward the south. These fractures are mostly in the rhyolite of Tannenbaum Hill.

Below the rhyolite of Tannenbaum Hill, fractures have similar orientations to the interval above the rhyolite. Orientations of fractures in the interval from $1,188 \mathrm{~m}$ to $1,504 \mathrm{~m}(3,900$ to $4,937 \mathrm{ft})$ are shown in Figures 3-1g and 3-1h. Most of the fractures strike north-northeast and dip steeply both toward the west and east, although there is a scatter of orientations.

\subsubsection{Comparison of the FMS Image with Core}

Fifteen intermittent cores were taken in Exploratory Hole UE-18r. There is not a good correlation of fractures visible in the core with those identified on the FMS. This may be because the FMS is an image of the wellbore wall and is not of the same piece of rock as the core. Also the FMS image does not provide full wellbore coverage. Some of the cores were taken in intervals where the wellbore is washed out.

\subsection{Monitoring Well UE-20bh \#1}

Monitoring Well UE-20bh\#1 was logged with both the FMS and the Schlumberger BHTV for a comparison of the two types of image logs. The saturated depth interval between $675 \mathrm{~m}$ $(2,213 \mathrm{ft})$ and $856 \mathrm{~m}(2,808 \mathrm{ft})$ was logged with both tools. A thorough comparison of the two logs is not within the scope of this fracture analysis task; however, data from both are shown in Figure 3-2.

\subsubsection{Fracture Orientations in UE-20bh \#1}

Orientations of fractures in the entire interval logged with the FMS are shown in Figures 3-2a and $3-2 b$. The greatest majority of fractures strike north-northeast; however, there is a scatter of 


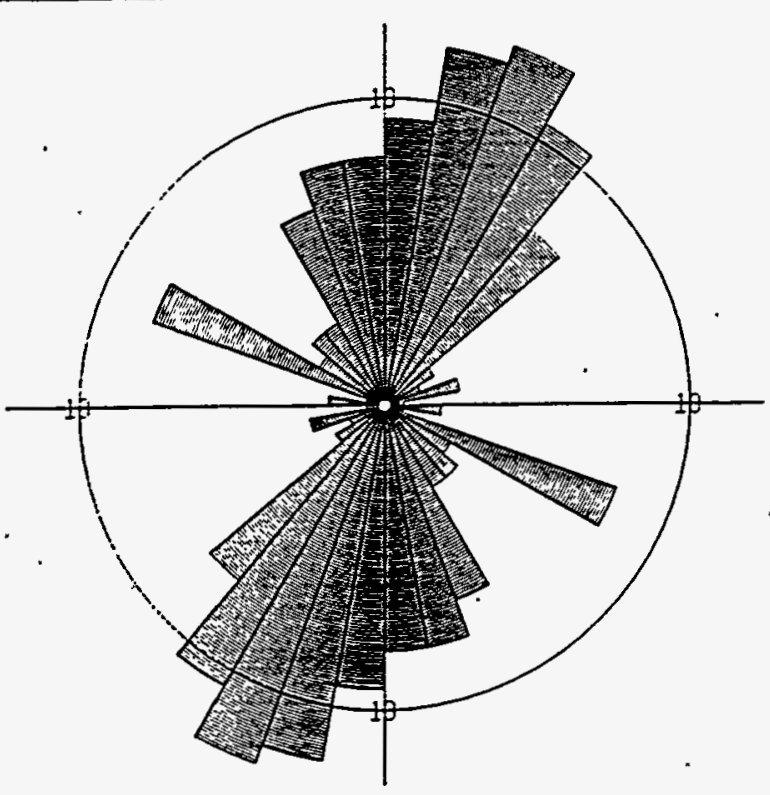

Figure 3-2a

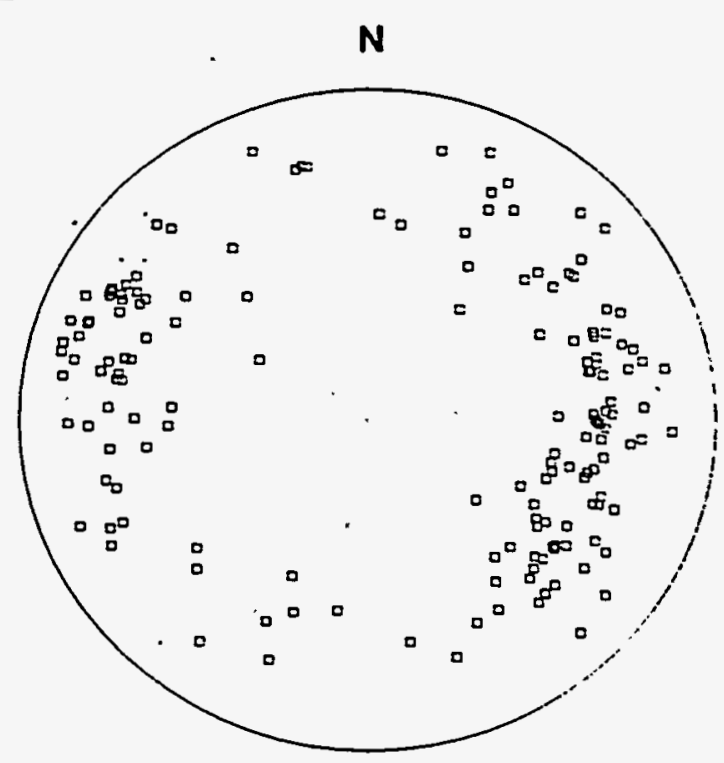

Figure 3-2b

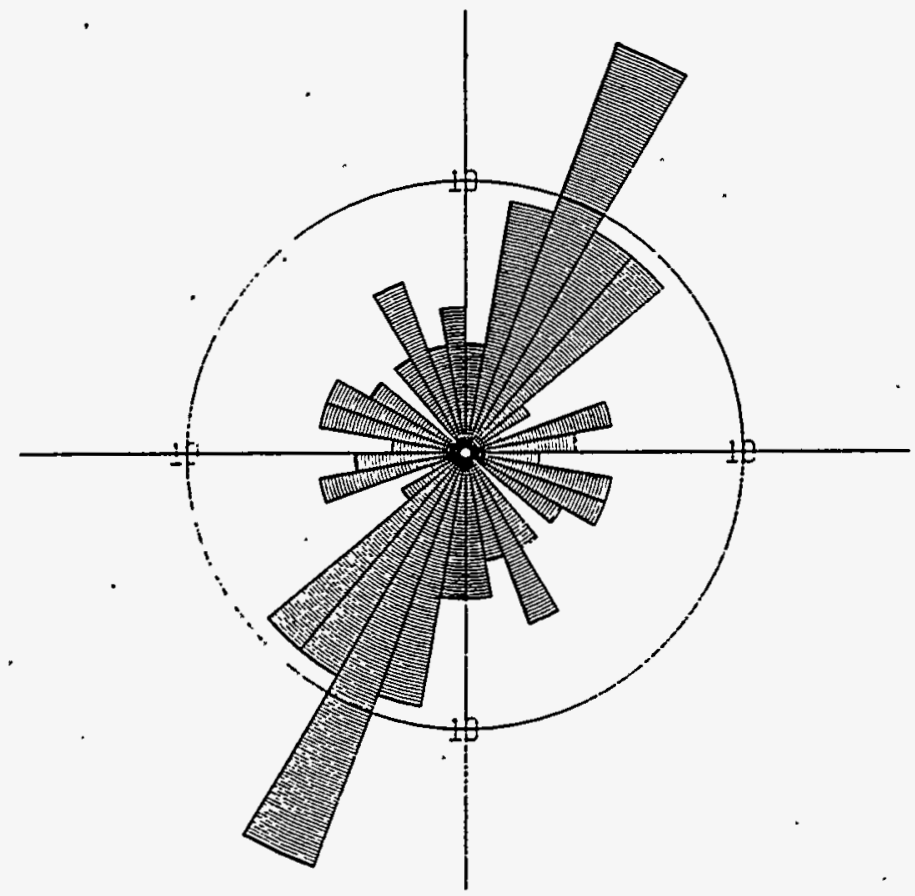

Figure 3-2c

Diagrams showing fracture orientations in Monitoring Well UE-20bh \#1 for the entire logged interval. 3-2a) Rose diagram of 161 strikes identified in the FMS log. Petal lengths are percent of total-data points in a 10-degree azimuth interval. 3-2b) Lower hemisphere, equal area stereographic projection of 161 poles to fracture planes in the FMS log. 3-2c) Rose diagram of 75 poles to fractures identified in the BHTV. Petal lengths are percent of total data points within a 10-degree azimuth interval. North is at the top of each figure. 
strikes over a 60 to 80 degree range. A distinct subset of 13 fractures strikes perpendicular to the majority trend between 60 and 70 degrees west. Figure 3-2b shows that both sets of fractures have steep dips. For comparison, strikes of fractures identified with the BHTV are indicated in Figure 3-2c.

Although the data set is smaller for the BHTV, strikes determined with the BHTV are very similar to those in the FMS.

\subsubsection{Comparison of the UE-20bh \#1 Wellbore Images with Core}

The short core interval from $726 \mathrm{~m}(2,382 \mathrm{ft})$ to $735 \mathrm{~m}(2,412 \mathrm{ft})$ contained several fractures, both closed and open (Figure 2-15). Open fractures were identified in core at $726 \mathrm{~m}(2,382 \mathrm{ft})$ depth. Other fractures present in the core were closed. The BHTV image shows several irregular fractures at $726 \mathrm{~m}(2,382 \mathrm{ft})$ depth. No other fractures are identifiable on the BHTV over the cored interval. In this example, the BHTV did not image all fractures but did image the open, more significant fractures. In the FMS analysis of the same core interval, no fractures were identified in the interval containing the open fractures at $726 \mathrm{~m}(2,382 \mathrm{ft})$. However, questionable fractures were identified at $731 \mathrm{~m}(2,398 \mathrm{ft})$ on the FMS in which healed and closed fractures were identified in core.

\subsection{Well ER-20-5 \#1}

The location of Well ER-20-5 \#1 is shown in Figure 1-1. The well was logged with a BHTV over the depth interval of $626 \mathrm{~m}(2,053 \mathrm{ft})$ to $826 \mathrm{~m}(2,710 \mathrm{ft})$, all within the Topopah Spring Tuff. Because of poor borehole conditions within nonwelded tuff intervals, the BHTV image is poor; and fractures are not easily identifiable. The moderately welded tuff between $704 \mathrm{~m}$ $(2,310 \mathrm{ft})$ and $786 \mathrm{~m}(2,580 \mathrm{ft})$ yielded a good image on the BHTV, and most of the fractures selected from the log are from within that interval.

\subsubsection{Fracture orientations in Well ER-20-5 \#1}

Orientations of fractures identified on the BHTV log from Well ER-20-5 \#1 are shown in Figure 3-3. The stereographic projection in Figure 3-3a illustrates that the fractures from the entire logged interval are generally of steep dip because their poles plot near the rim of the circle. The clustering of poles onto several groups suggests the presence of multiple fracture sets. 


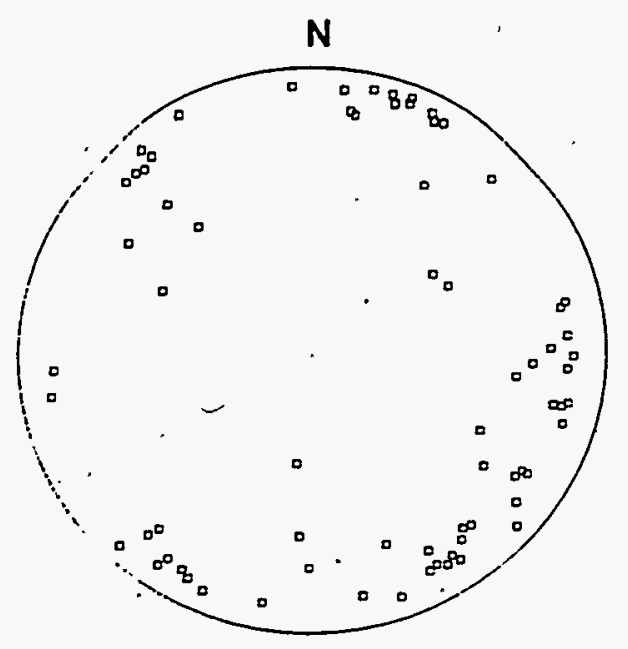

Figure $3-3 a$

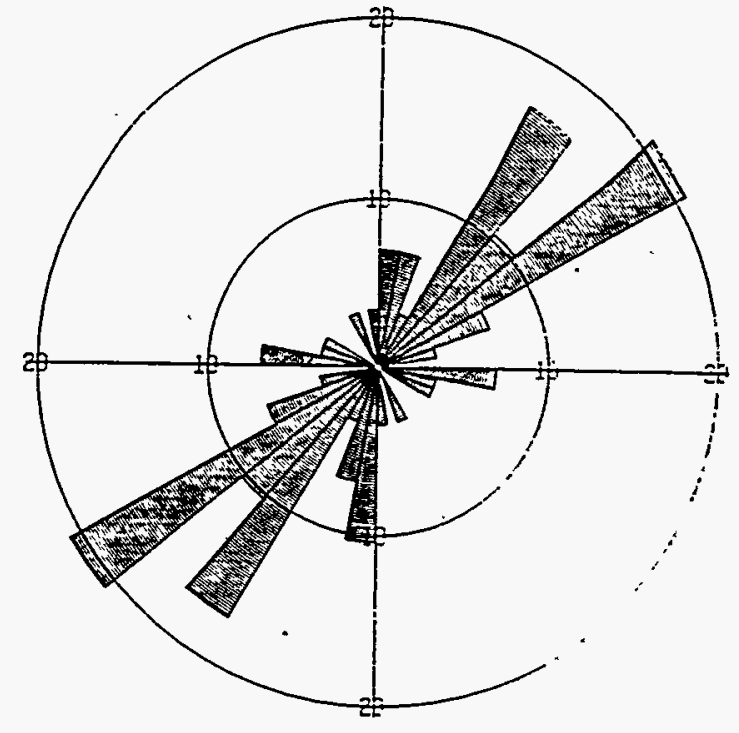

Figure 3-3b

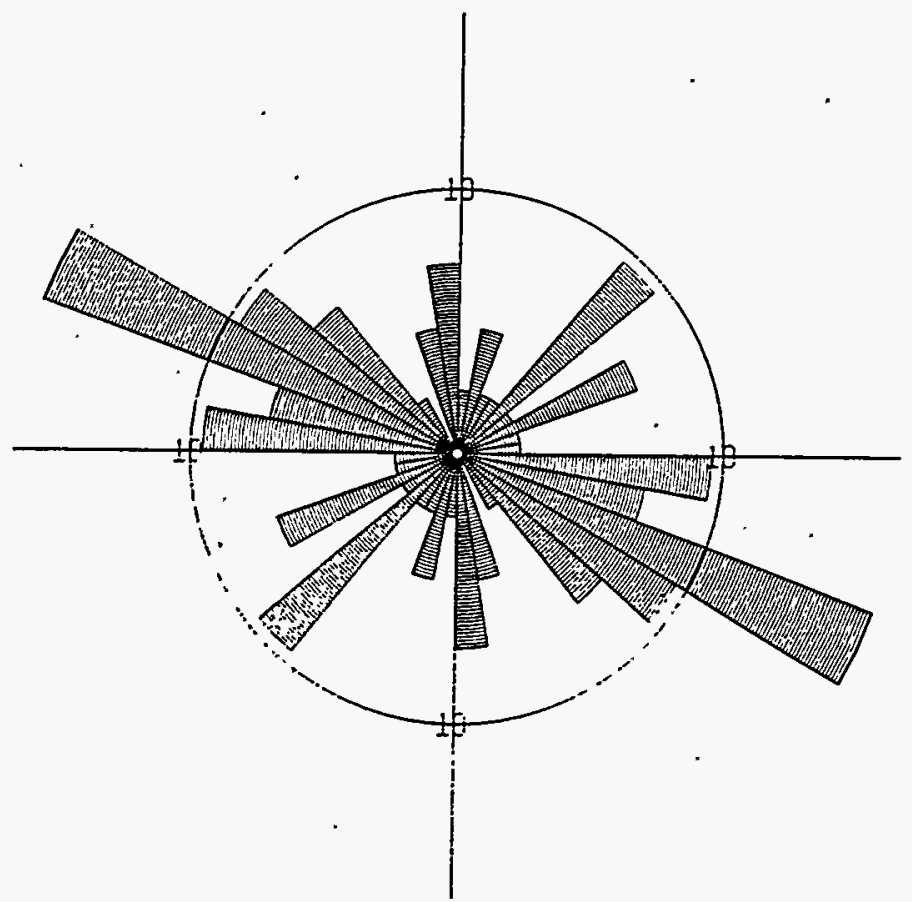

Figure 3-3c

Fracture orientation diagrams for Well ER-20-5 \#1. North is to the top of each figure. 3-3a) Equal area, lower hemisphere stereographic projection of 71 poles to fracture planes from the entire logged interval. 3-3b) Rose diagram of 29 fracture strikes from the depth interval 626 meters $(\mathrm{m})(2,053$ feet $[\mathrm{ft}])$ to $734 \mathrm{~m}$ $(2,408 \mathrm{ft})$. Petal lengths are percent of points in a 10-degree azimuth interval. $3-3 \mathrm{c})$ Rose diagram of 42 fracture strikes from the depth interval below $734 \mathrm{~m}(2,408 \mathrm{ft})$.

Figure 3-3a-c

Fracture Orientation Diagrams for Well ER-20-5 \#1 
Orientations were further differentiated by depth interval. Figure $3-3 b$ shows orientations of a small set of fractures identified in the depth interval $626 \mathrm{~m}(2,053 \mathrm{ft})$ to $734 \mathrm{~m}(2,408 \mathrm{ft})$.

Fractures in this upper interval strike generally northeast. Orientations of fractures in the depth

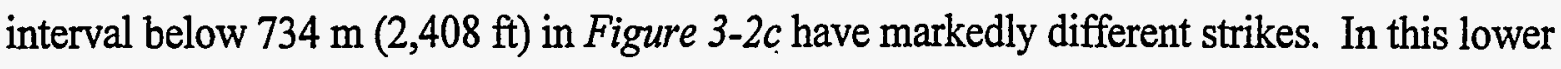
interval, most fractures strike west-northwest; however, the northeast strike is present. The change in fracture strikes happens at about $734 \mathrm{~m}(2,408 \mathrm{ft})$ depth, within the moderately welded . tuff. There is an overlap of the two fracture orientation sets with both sets occurring locally at the same depth.

\subsection{Well ER-20-2 \#1}

The location of well ER-20-2 \#1 is shown in Figure 1-1. A BHTV log was run in this hole from $690 \mathrm{~m}(2,264 \mathrm{ft})$ to $770 \mathrm{~m}(2,525 \mathrm{ft})$.

\subsubsection{Fracture Orientations in Well ER-20-2 \#1}

Orientations of fractures in Well ER-20-2 \#1 are shown in Figure 3-4a. Only 17 fractures were described from this $\log$. The stereographic projection in Figure $3-4 \mathrm{~b}$ illustrates that fractures from the entire logged interval are generally steeply dipping. Fractures in this well generally trend northeast-southwest with one minor, perpendicular fracture set.

\subsection{Synopsis of the Fracture Orientation of the Data Sets}

Composite fracture orientation diagrams for each well are shown on Figure 3-5. These composite figures contain all fractures described in each log. The dominant fracture set described through orientation analysis generally trends north-northeast to south-southwest. These fractures generally are parallel to the north-northeast-trending normal faults of the area. In some wells there is a distinctly different fracture orientation with increase in depth. The shallow fractures of Exploratory Hole UE-18r trend east-northeast and are located in younger volcanic units that do not contain major north-northeast-trending normal faults. The lower fractures of this well trend more north-northeast, parallel to the regional fault system. This well is located in volcanic units within the moat of the Timber Mountain Caldera, which is structurally different than the wells on Pahute mesa. Well ER-20-5 \#1 also exhibited separate fracture sets with depth. 


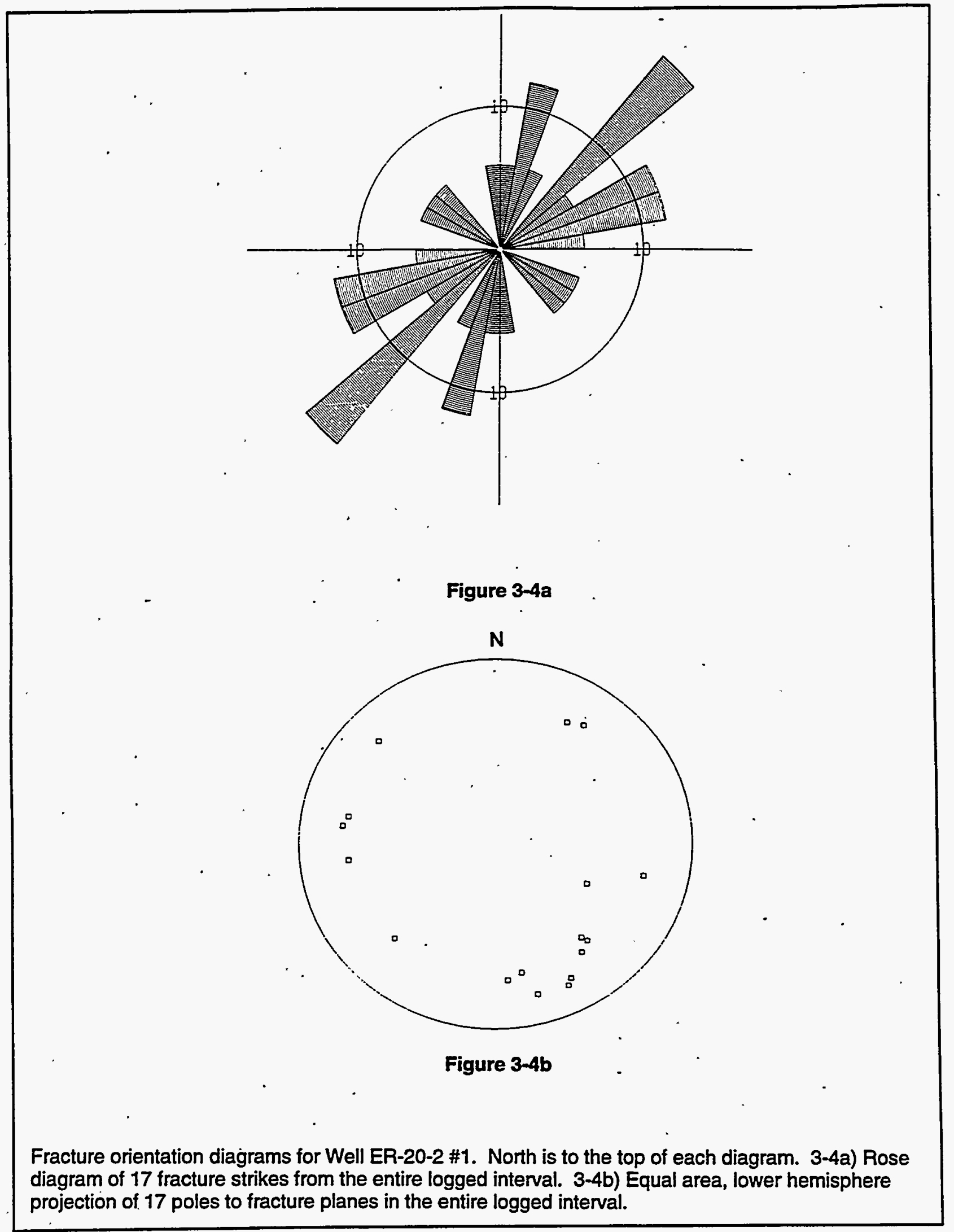

Figure 3-4a-b

Fracture Orientation Diagrams for Well ER-20-2 \#1 


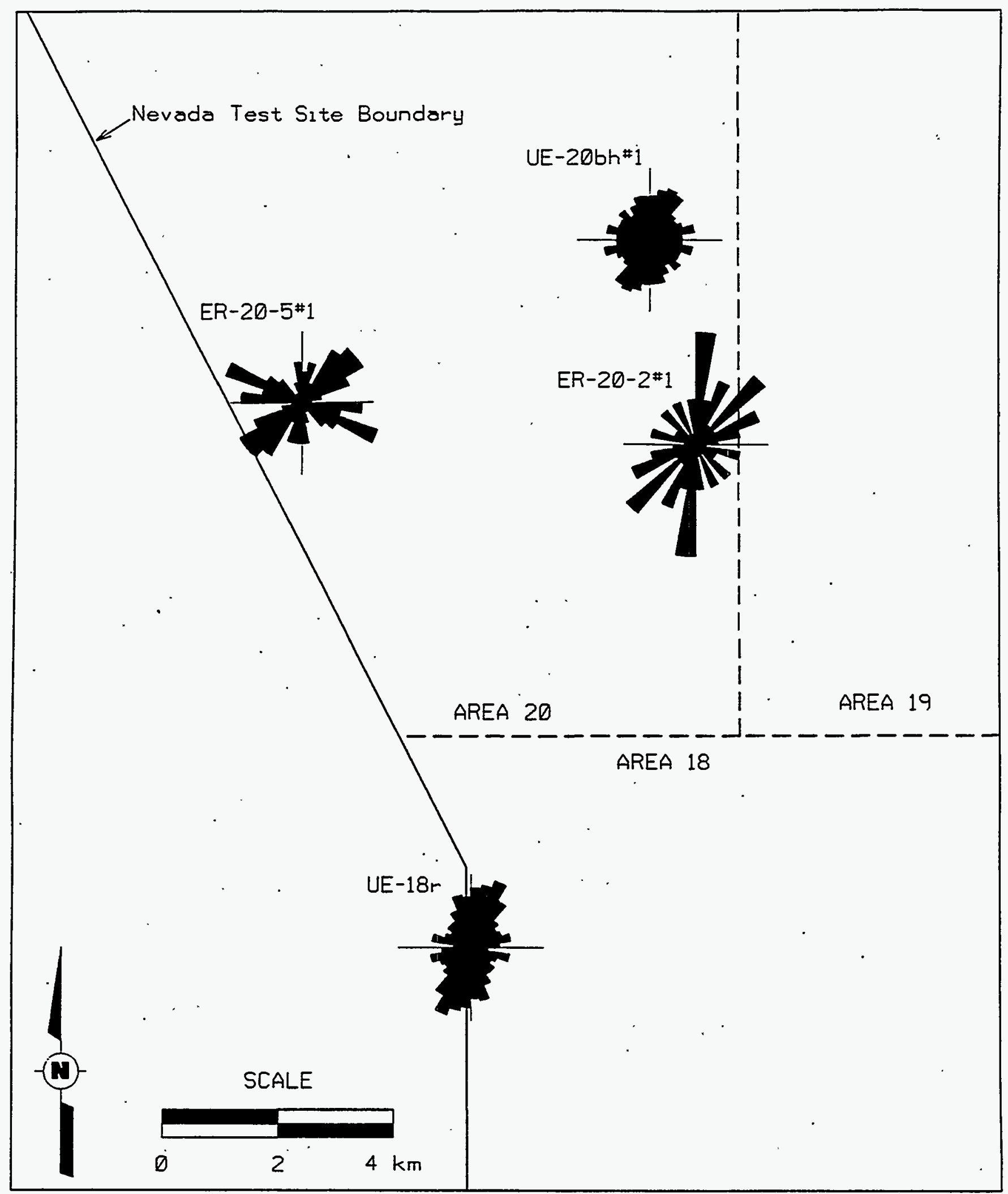

Figure 3-5

Composite Fracture Strikes for the Pahute Mesa Area 


\subsection{Cumulative Analysis of Fracture Data}

Previous analyses and discussions of fracture attributes in this study were based on fracture data sets from individual holes. However, in order to acquire information on the regional aspects of these attributes it was necessary to analyze the fracture attributes based on a single cumulative data set comprised of fracture data from all the holes examined. Observations of fracture attributes based on the results of this analysis are discussed in the following text. General observations of fracture attributes will be discussed as well as attributes relative to HSU and HGU.

\subsection{General Observations of Fracture Attributes}

The following are general observations of fracture attributes based on cumulative data from all the holes. As will be shown, data from the Area 18 holes have a significant influence on the cumulative analysis of the data. Therefore, some attributes were also analyzed using the following two data subsets:

- Data from the Pahute Mesa holes only (i.e., UE-19x, U-20c/UE-20c, UE-20e\#1, UE-20f, and UE-20bh\#1)

- Data from the Area 18 holes only (i.e., UE-18r and.UE-18t)

\subsubsection{Fracture Density}

The density of open and closed fractures; incorporating data from all drill holes in the study, is approximately one fracture every $0.6 \mathrm{~m}$ ( $2 \mathrm{ft}$ ) vertically (Figure 4-1). However, because fractures from Area 18 holes represent 75 percent of the fractures recorded, fracture data from Area 18 holes, particularly UE-18t, have a significant influence on the cumulative analysis of the data. This becomes apparent when comparing the density of open and closed fractures based on data from all holes with data from Pahute Mesa holes or Area 18 holes separately (Figure 4-1).

\subsubsection{Orientation}

Approximately 50 percent of all the fractures observed and 73 percent of the open fractures observed are high-angle (Figure 4-2a). This corresponds fairly close to what other researchers have found at the NTS Yucca Mountain site where approximately 60 percent of fractures range from $40^{\circ}$ to $90^{\circ}$ (Maldonado and Koether, 1983). The percentage of closed fractures exceeds the . percentage of open fractures with respect to all orientations when data from all the holes are considered. However, the influence of the abundance of closed fractures in the Area 18 holes is 


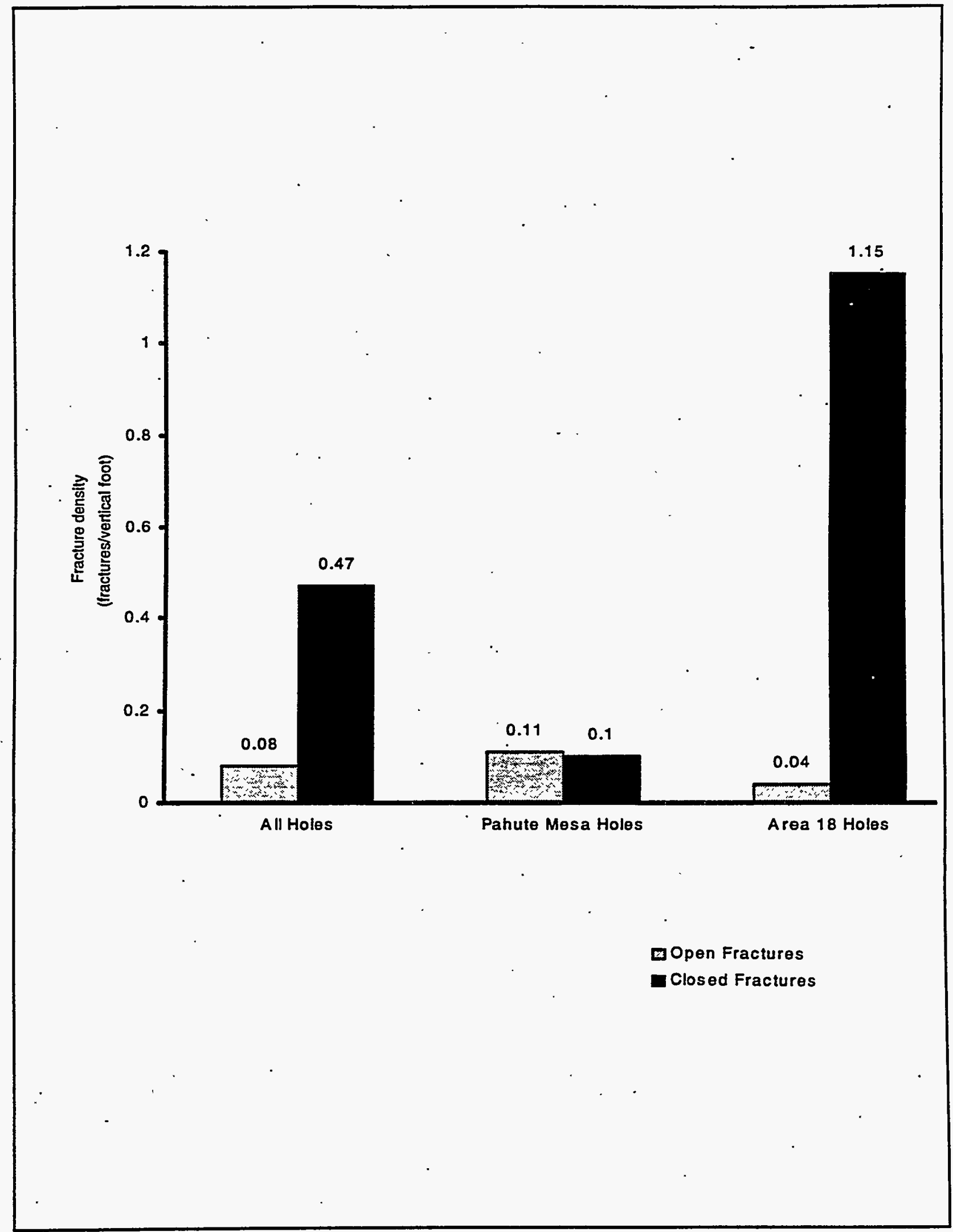

Figure 4-1

Summary of Fracture Density 


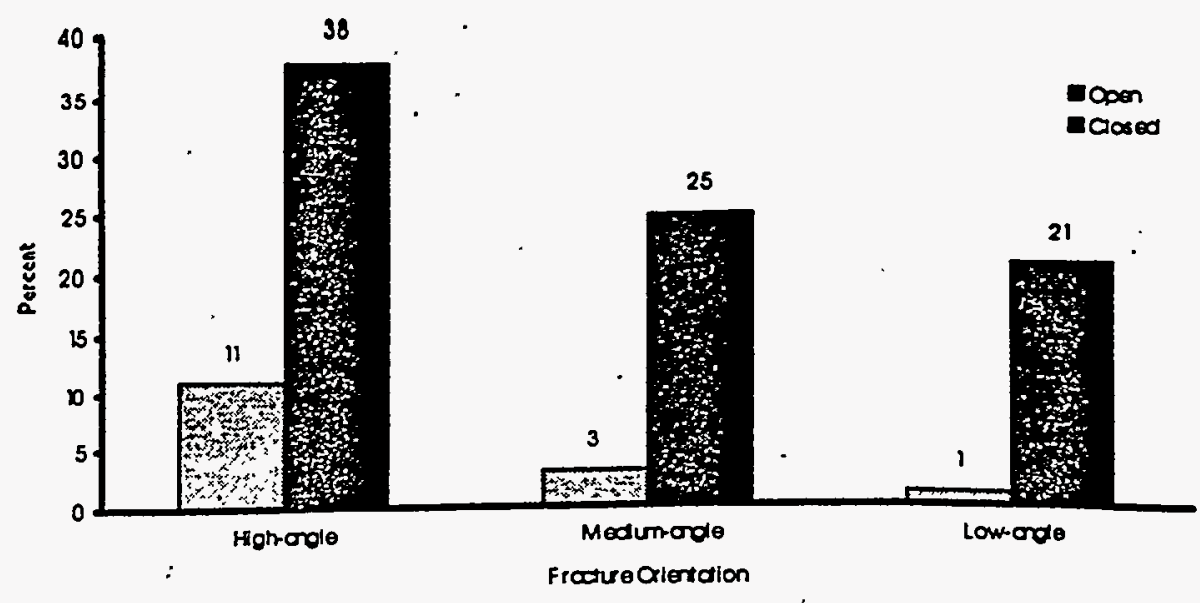

Figure 4-2a

Distribution of Open and Closed Fractures Relative to Orientation for All Holes

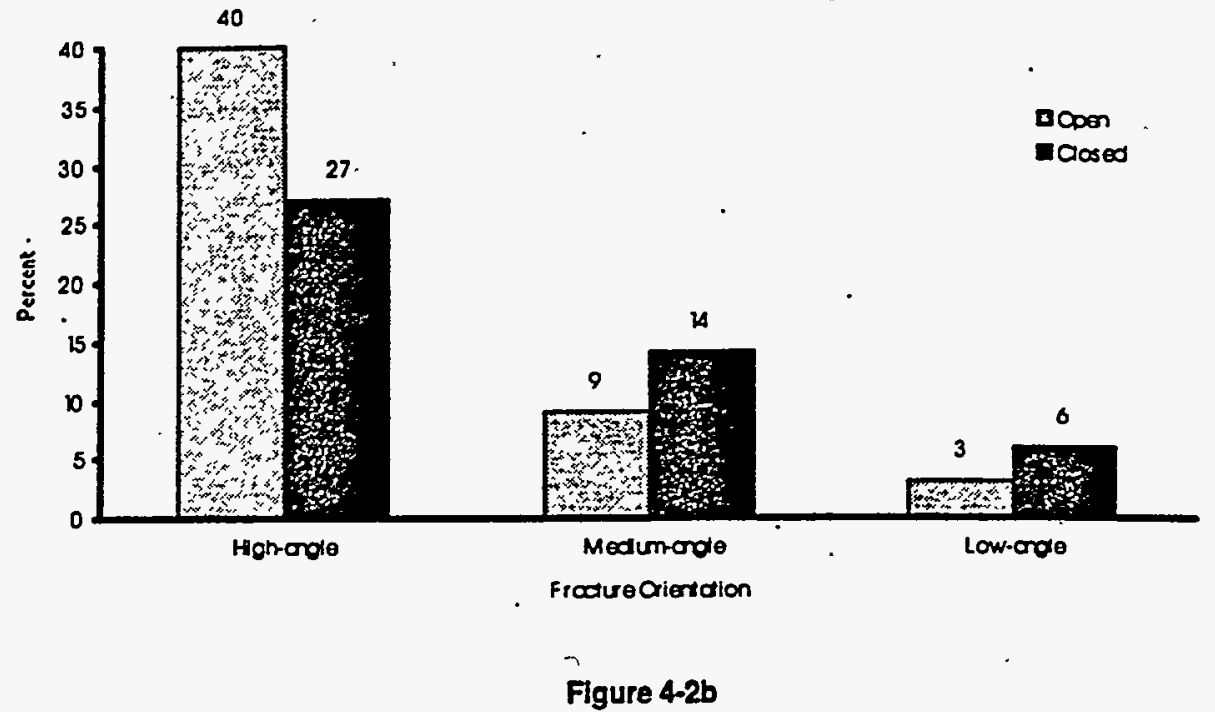

Dlstribution of Open and Closed Fractures Relative to Orientation for Pahute Mesa Holes Only

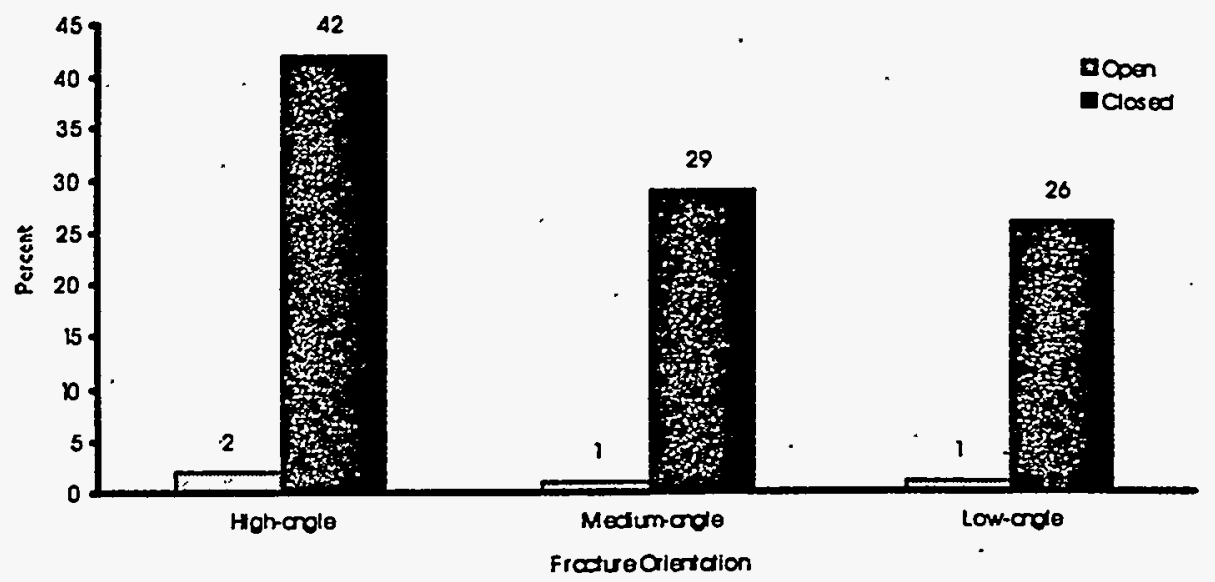

Figure 4-2c

Distrlbution of Open and Closed Fractures Relative to Orlentation for Area 18 Holes Only

Figure 4-2a-c

Summary of Fracture Distribution Relative to Orientation 
readily apparent when comparing Figures $4-2 a, 4-2 b$, and 4-2c: Based on data from the Pahute Mesa holes, only the percentage of high-angle open fractures exceeds that for high-angle closed fractures.

\subsubsection{Aperture and Openness}

Few of the open fractures examined were 100 percent open. Instead, the vast majority were partially closed with secondary mineral fillings. When aperture was observed along fracture traces, it usually averaged less than $1 \mathrm{~mm}(0.04 \mathrm{in}$.) in width.

\subsubsection{Mineralogy of Fracture Coatings}

The majority of the open fractures examined appeared to be $90-100$ percent coated with secondary minerals. The minerals most often observed as secondary mineral coatings were chalcedony, euhedral quartz, calcite, zeolite, clay, and $\mathrm{Fe} / \mathrm{Mn}$ oxides (Figure 4-3a). These were also the common fracture-coating minerals observed at Yucca Mountain Core Holes USW G-1 and USW G-2.(Maldonado and Koether, 1983; Carlos, 1990). Similar changes in relative abundances of these minerals were noted at both study areas. Zeolite and chalcedony occurred more often in fractures from the Pahute Mesa holes, while clay and calcite occurred more often in fractures from the Area 18 holes (Figures 4-3b and 4-3c).

\subsection{Fracture Attributes Within Hydrostratigraphic Units}

The following is an analysis and discussion of the fracture attributes relative to the hydrostratigraphy of Pahute Mesa/Timber Mountain area. Fracture attributes are analyzed and discussed for each of the following hydrostratigraphic units: TMA, TC, TCB, TBA, and BAQ. Due to the influence of data from Area 18 holes on the analysis of particular fracture attributes, data for these attributes are presented in three sets:

- For all holes

- Pahute Mesa holes

- Area 18 holes

\subsubsection{Fracture Density}

Figure 4-4a indicates that, with respect to all the holes, the TBA and BAQ have the highest density of fractures. However, it should be noted that only a limited amount of core from holes UE-20e \#1 and UE-20f was available from the TBA and BAQ. 


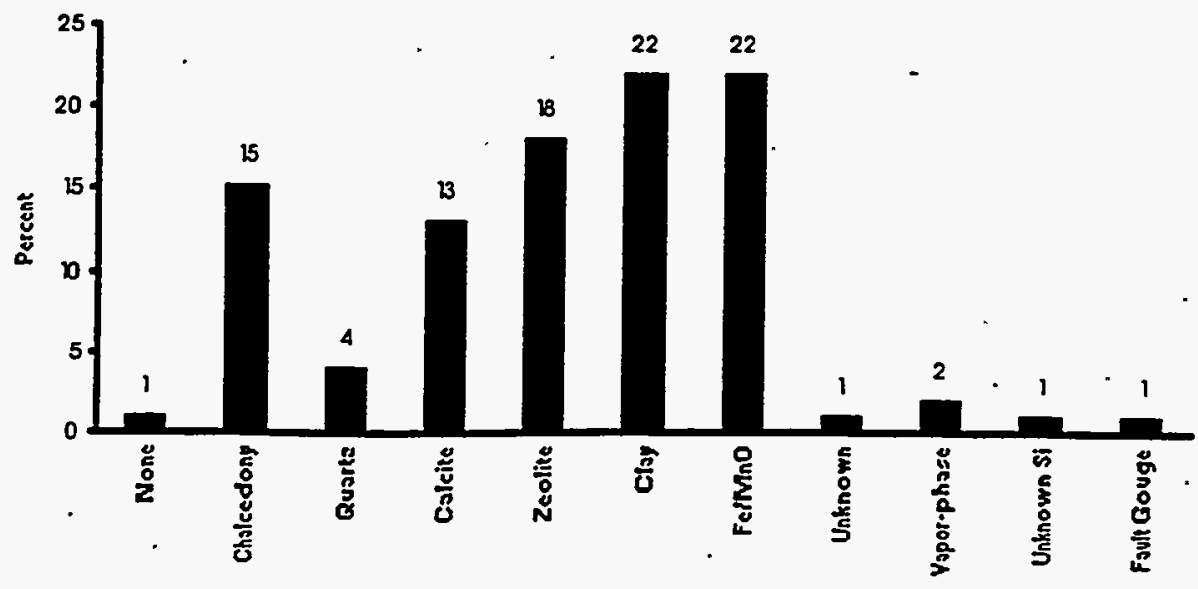

Froctureminerd Coctinos

Figure 4-3a

Distribution of Fracture Mineral Coatings for All Holes

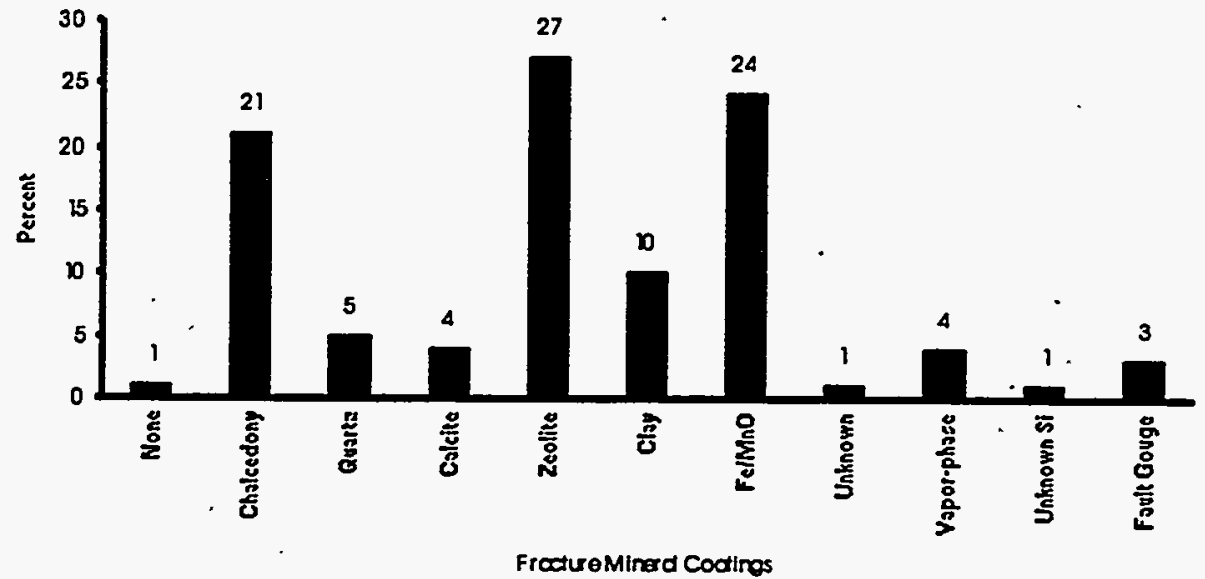

Figure 4-3b

Distribution of Fracture Mineral Coatings for Pahute Mesa Holes Only

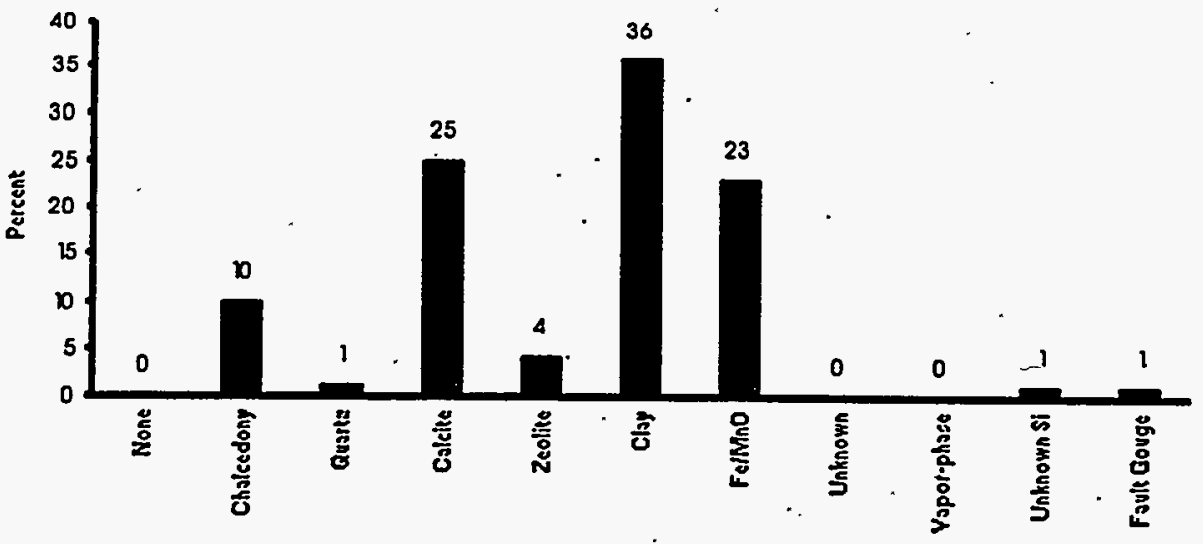

Frocture Minard Coctinos

Figure 4-3c

Distrlbution of Fracture Mineral Coatings for Area 18 Holes Only

Figure 4-3a-c

Summary of the Distribution of Fracture-Mineral Coatings 


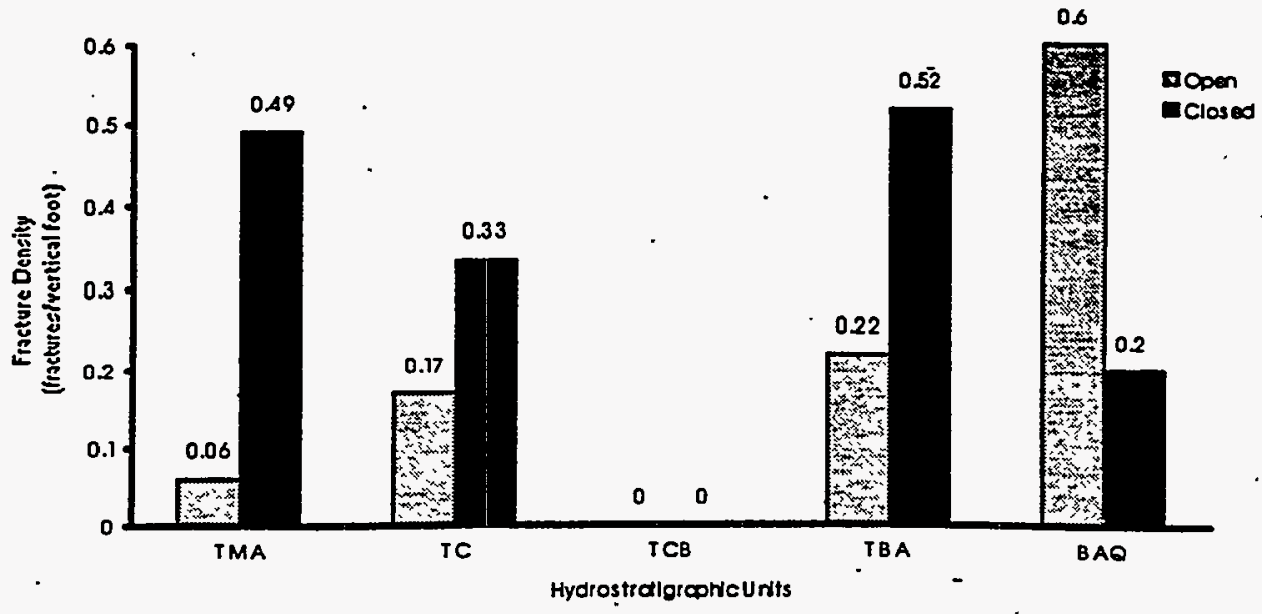

Figure 4-4a

Denslty of Open and Closed Fractures Relative to Hydrostratigraphy for All Holes

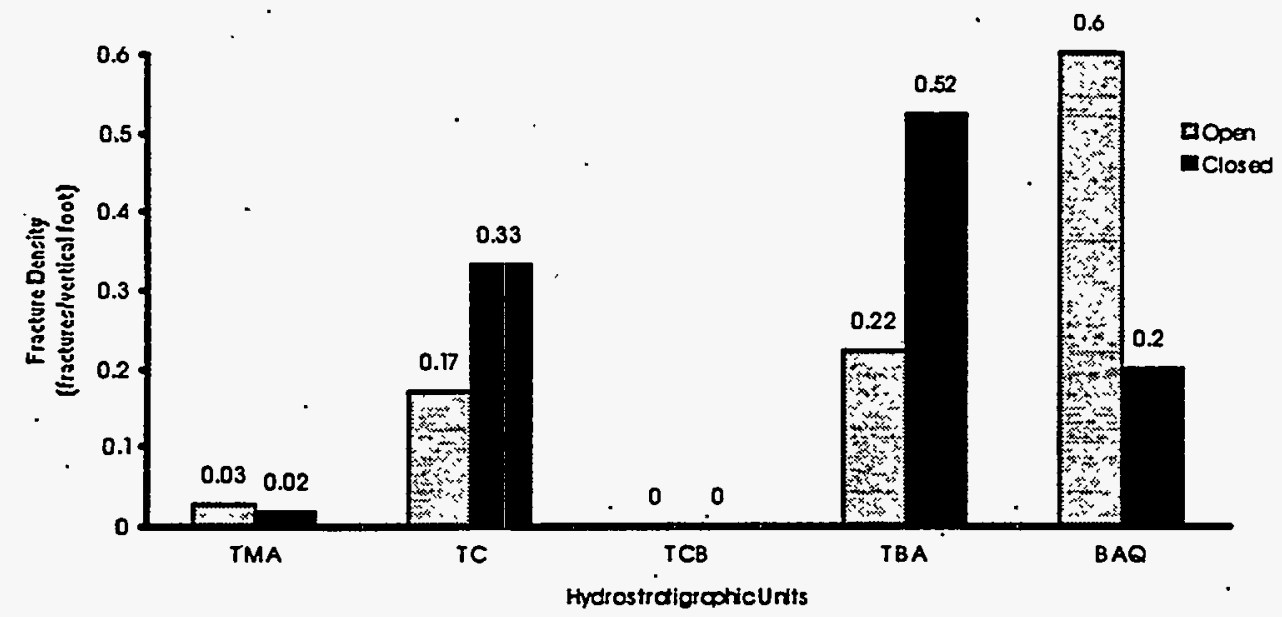

Figure $4-a b$

Density of Open and Closed Fractures Rielative to Hydrostratigraphy for Pahute Mesa Holes Only

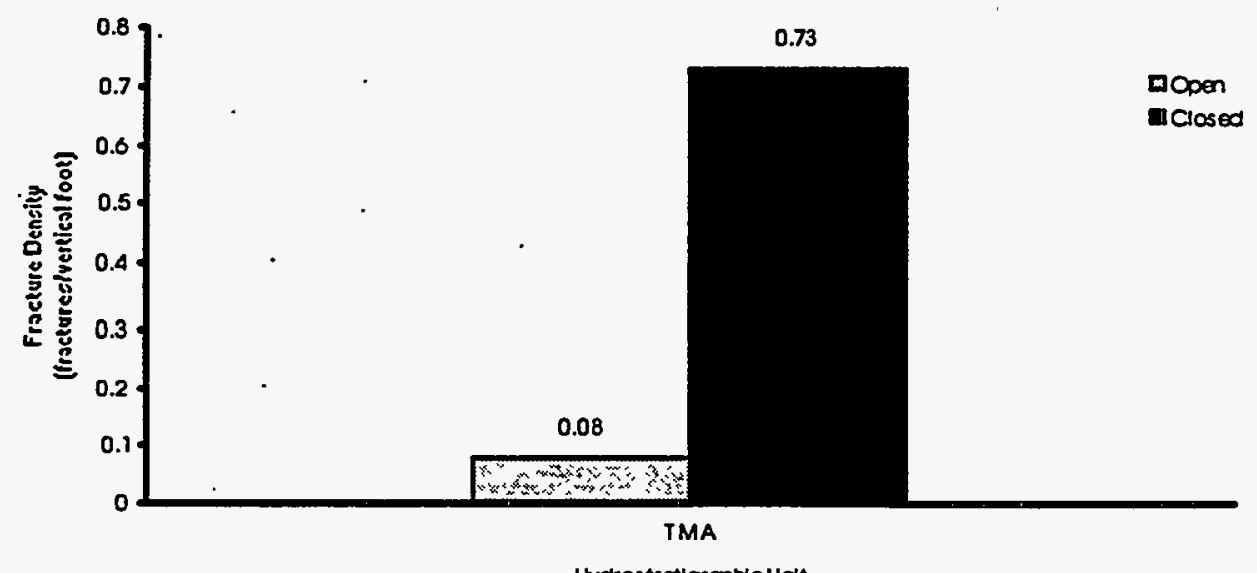

- Hydrostrolgropicunt

Figire 4-4c

Density of Open and Closed Fractures Relative to Hydrostratigraphy for Area 18 Holes Only

Figure 4-4a-c

Summary of Fracture Density Relative to Hydrostratigraphy 
The fracture densities for TMA and TC are approximately equal with respect to data from all the holes, with the density of closed fractures exceeding that for open fractures in both holes (Figure 4-4a). The much higher density of closed fractures versus open fractures within the TMA appears to be the result of the influence of the Area 18 holes which have a much higher density of closed fractures than open fractures within the TMA (Figure 4-4c). With respect to Pahute Mesa holes, the TC has a much higher density of fractures than TMA (Figure 4-4b). This is probably due to the high percentage of poorly fractured vitric-tuff aquifer that comprises the TMA in the holes examined. No fractures were observed within the TCB; which is not surprising since poorly fractured TCU comprises much of the TCB.

\subsubsection{Aperture and Openness}

Table 4-1 shows that open fractures in the TMA were observed to have the largest average apertures, averaging $0.72 \mathrm{~mm}(0.03 \mathrm{in}$.). Open fractures within the TC were observed to have the second largest average apertures at $0.53 \mathrm{~mm}(0.02 \mathrm{in}$.), followed by open fractures within the $\mathrm{BAQ}$ at $0.3 \mathrm{~mm}(0.01 \mathrm{in}$.) and fractures within the TBA at $0.08 \mathrm{~mm}(0.003 \mathrm{in}$.).

Although the TBA and BAQ were observed to have the highest density of fractures, Table 4-1 shows that not only do they have the smallest average apertures, but they also are almost completely closed, averaging less than 10 percent open. Fractures in the TC were observed to average generally less than 50 percent open, whereas fractures in the TMA showed a wide variability in the average percent open ranging from $10-100$ percent open.

\subsubsection{Mineralogy of Fracture Coatings}

Because chalcedony, quartz, calcite, zeolite, clay, and iron and manganese oxides are the most commonly occurring fracture-coating minerals observed in this study (Figure 4-3a), all other minerals observed are grouped together for the remaining analyses and discussions.

Three secondary mineral coatings were observed to occur most often in fractures within the TMA (Figure 4-5a). These minerals were calcite, clay, and iron and manganese oxides. However, a comparison of Figures 4-5a,4-5b, and 4-5c shows that this distribution is strongly influenced by data from the Area 18 holes. Data from Pahute Mesa holes only show the occurrence of secondary minerals within the TMA more evenly distributed among all the minerals observed. 
Table 4-1

Fracture Aperture and Percent Open Data Summary

(Data Grouped by Hydrostratigraphic Units)

\begin{tabular}{|c|c|c|c|c|c|c|c|c|c|c|c|c|c|c|c|c|}
\hline & \multicolumn{8}{|c|}{ Average Aperture (millimeters) } & \multicolumn{8}{|c|}{ Percent Open Category } \\
\hline HSU & UE-18r & UE-18t & UE-19x & $\begin{array}{l}\text { UE-20 } \\
\text { bh \#1 }\end{array}$ & $\begin{array}{l}\text { UE-20c } \\
\text { U-20c }\end{array}$ & $\begin{array}{l}\text { UE-20 } \\
\text { e\#1 }\end{array}$ & UE-20f & $\begin{array}{c}\text { Average } \\
\text { of Data }\end{array}$ & UE-18r & UE-18t & UE-19x & $\begin{array}{c}\text { UE-20 } \\
\text { bh\#1 }\end{array}$ & $\begin{array}{c}\text { UE-20c } \\
\text { U-20c }\end{array}$ & $\begin{array}{c}\text { UE-20 } \\
\text { e\#1 }\end{array}$ & UE-2Of & $\begin{array}{l}\text { Average } \\
\text { of Data }\end{array}$ \\
\hline $\begin{array}{l}\text { Timber } \\
\text { Mountain } \\
\text { Aquifer } \\
\text { (TMA) }\end{array}$ & 1.09 & 0.78 & 0.39 & - & - & - & - & 0.72 & $50-90$ & $10-50$ & $50-100$ & - & - & - & - & $10-100^{1}$ \\
\hline $\begin{array}{l}\text { Tuff Cone } \\
\text { (TC) }\end{array}$ & - & - & 0.78 & 0.84 & 0.42 & 0.03 & 0.19 & 0.53 & - & - & $1-50$ & $1-50$ & $1-50$ & $1-10$ & $1-10$ & $1-50$ \\
\hline $\begin{array}{l}\text { Bullfrog } \\
\text { Confining } \\
\text { Unit } \\
\text { (TCB) }\end{array}$ & - & - & - & - & - & - &.$^{2}$ & - & - & - & - & - & - & - & $\star^{2}$ & - \\
\hline $\begin{array}{l}\text { Belted } \\
\text { Range } \\
\text { Aquifer } \\
\text { (TBA) }\end{array}$ & - & 1 & - & - & - & 0.08 & $\star^{3}$ & 0.08 & - & - & - & - & - & $1-10$ & $\star^{3}$ & $1-10$ \\
\hline $\begin{array}{l}\text { Basal } \\
\text { Confining } \\
\text { Unit } \\
\text { (BCU) }\end{array}$ & - & - & - & - & - & - & - & - & - & - & - & - & - & - & - & - \\
\hline $\begin{array}{l}\text { Basal } \\
\text { Aquifer } \\
\text { (BAQ) }\end{array}$ & - & - & - & - & - & - & 0.3 & 0.3 & - & - & - & - & - & - & $1-10$ & $1-10$ \\
\hline
\end{tabular}

1 Percent open range expanded toward low end by the UE-18t data.

-.. Core representing unit either not available or not logged.

$233.2 \mathrm{~m}$ (109 ft) of TCB logged, but no open fractures observed.

3 Only $4 \mathrm{~m}$ (13 ft) of TBA logged, no open fracture observed. 


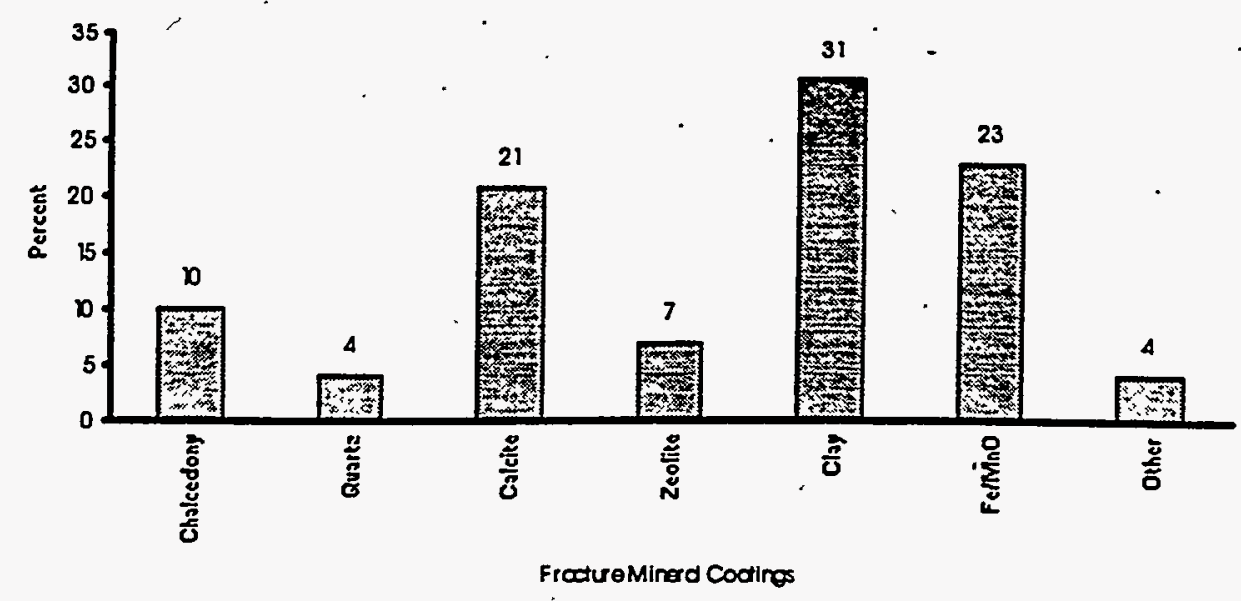

Figure 4-5a

Distribution of Fracture Mineral Coatings Whith the Timber Mountain Aquifer for All Holes

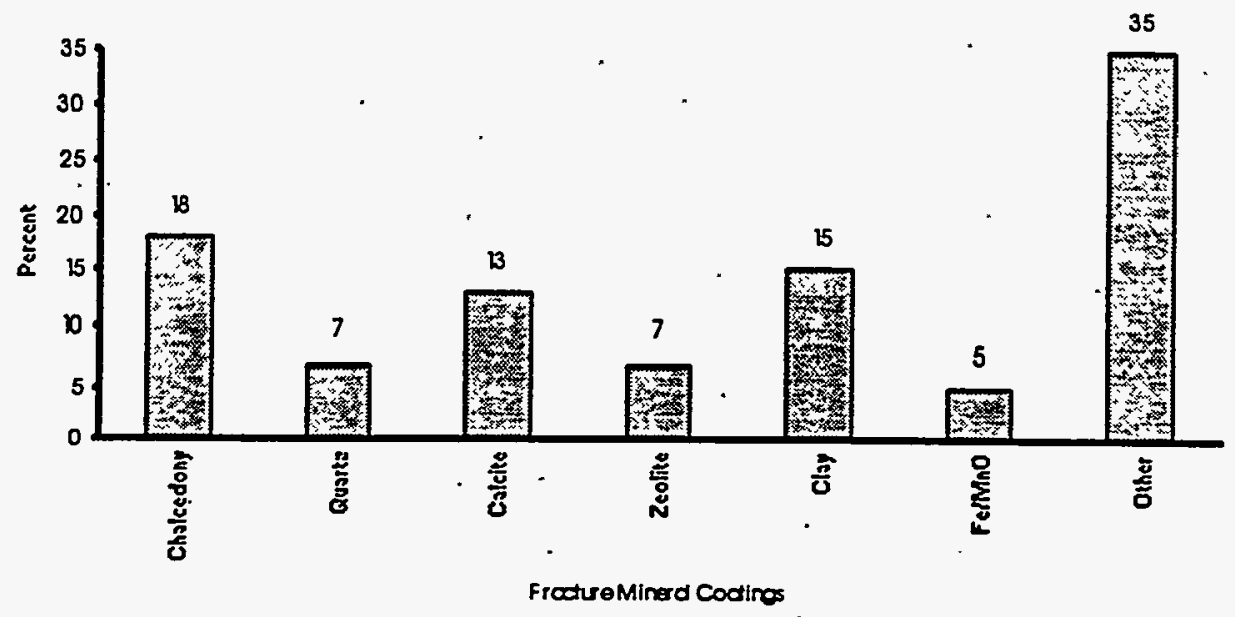

Figure 4-5b

Distribution of Fracture Mineral Coatings Within the Timber Mountain Aquifer for Pahute Mesa Holes Only

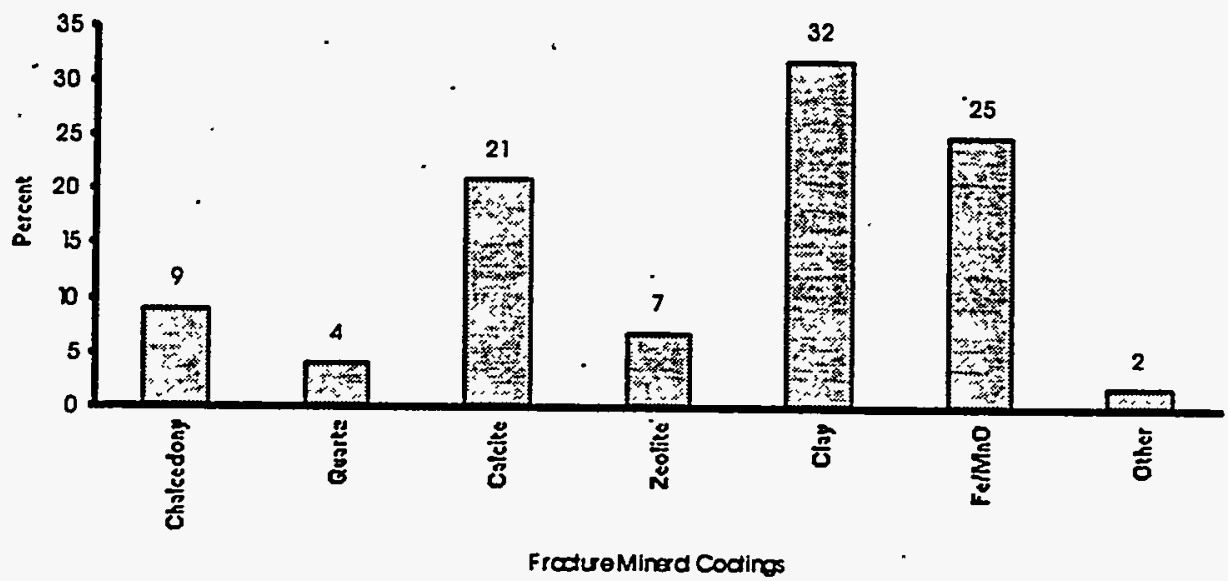

Figure 4-5c

Distribution of Fracture Mineral Coatings Within the Timber Mountain Aquifer for Area 18 Holes Only

Figure 4-5a-c .

Summary of the Distribution of Fracture Mineral

Coatings Within the TMA 
Although a wide variety of secondary mineral coatings were observed in fractures within the TC, chalcedony, zeolite, and iron and manganese oxides occurred most often (Figure 4-6a). Euhedral quartz, zeolite, clay, and iron and manganese oxides were the only secondary minerals observed in fractures within the TBA, with iron and manganese oxides occurring most often (Figure 4-6b). Only calcite and zeolite were observed in fractures within the BAQ (Figure 4-6c).

\subsection{Fracture Attributes Within Hydrogeologic Units}

The following is an analysis and discussion of the fracture attributes relative to the hydrogeology of.Pahute Mesa. Fracture attributes are analyzed and discussed for each of the following hydrogeologic units: (1) WTA, (2) LFA, (3) TCU, and (4) VTA. Because of the influence of data from Area 18 holes on the analysis of particular fracture attributes, data for these attributes are presented in three sets: for all holes, Pahute Mesa holes, and Area 18 holes.

\subsubsection{Fracture Density}

The highest density of fractures was observed within the WTA with a higher density of open fractures observed than closed fractures (Figure 4-7a). The LFA has the second highest fracture density, but closed fractures have a considerably higher density than open fractures. As expected, the TCU has a relatively low fracture density due to the less brittle nature of incorporated lithologies. The VTA has the lowest fracture density of all the hydrogeologic units because, like the TCU, the lithologies present within the VTA are much less brittle. In general, fracture densities derived in this study are consistent with similar data reported by Blankennagel and Weir (1973).

Comparison of Figures 4-7a, 4-7b, and 4-7c shows that although the data from Area 18 holes do have a significant influence, it is mainly with respect to the density of closed fractures.

\subsubsection{Aperture and Openness}

Table 4-2 illustrates that fractures within the VTA and LFA have the largest apertures, averaging just under $1 \mathrm{~mm}$. Fractures in the WTA and TCU have apertures averaging less than $0.5 \mathrm{~mm}$.

Open fractures in the WTA were generally greater than 50 percent open, whereas open fractures in the VTA, LFA, and TCU were generally less than 50 percent open. 


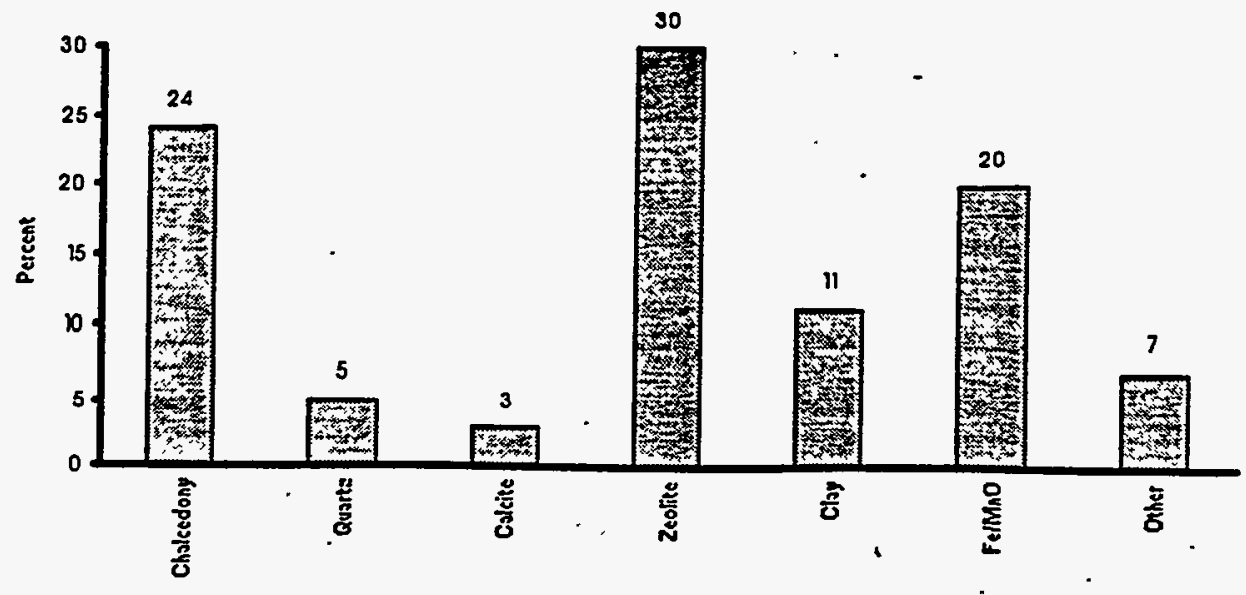

Frocture Minerd Coctios

Figure 4-6a

Distribution of Fracture Mineral Coatings Within the Tuff Cone Aqulfer for All Holes -

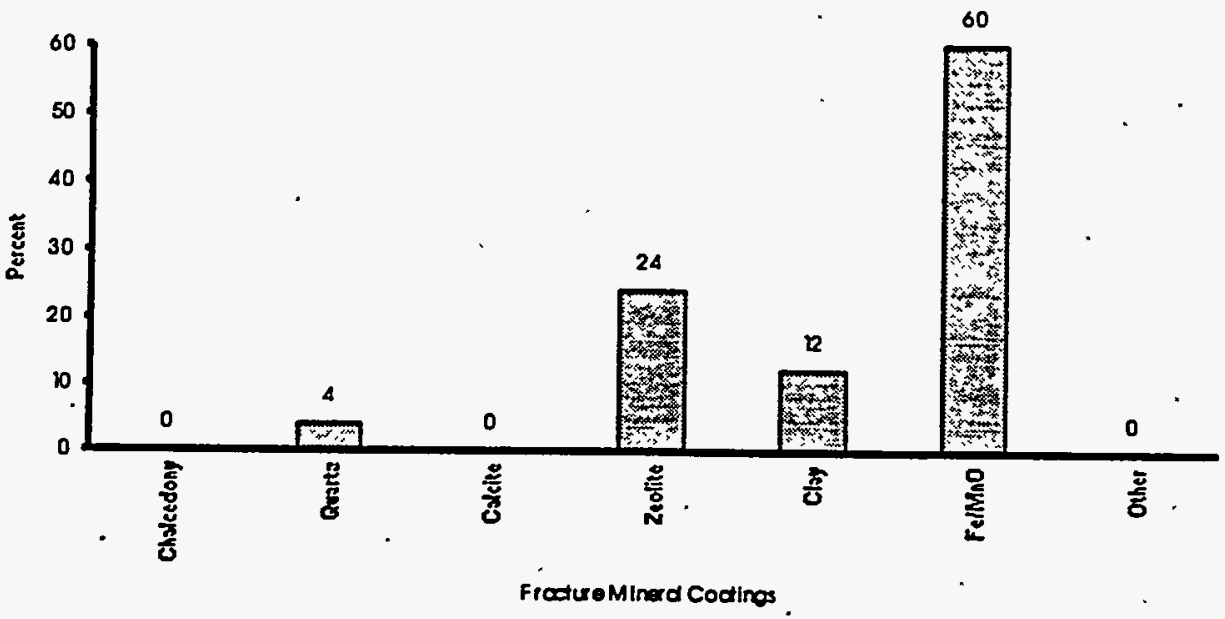

Figure 4-6b

Distribution of Fracture Mineral Coatings Whithin the Belted Range Aquffer for Pahute Mesa Holes Only

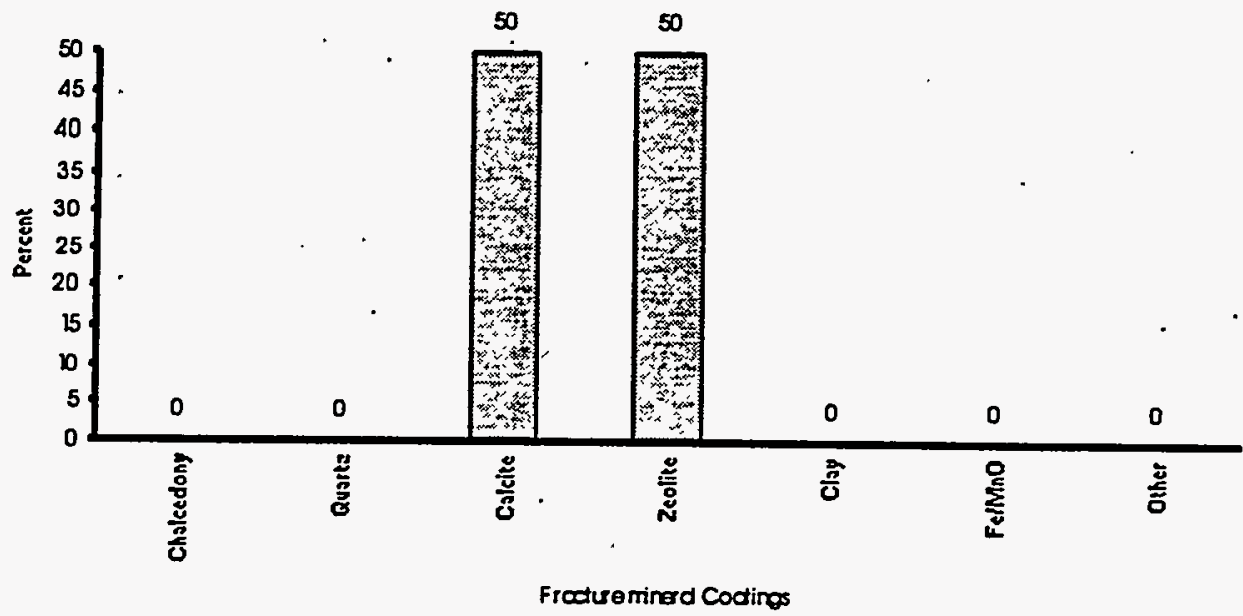

Figure $4-6 c$

Distribution of Fracture Mineral Coatings Whthin the Basal Aquifer for Area 18 Holes Only

Figure 4-6a-c

Summary of the Distribution of Fracture Mineral

Coatings Relative to Hydrostratigraphy 


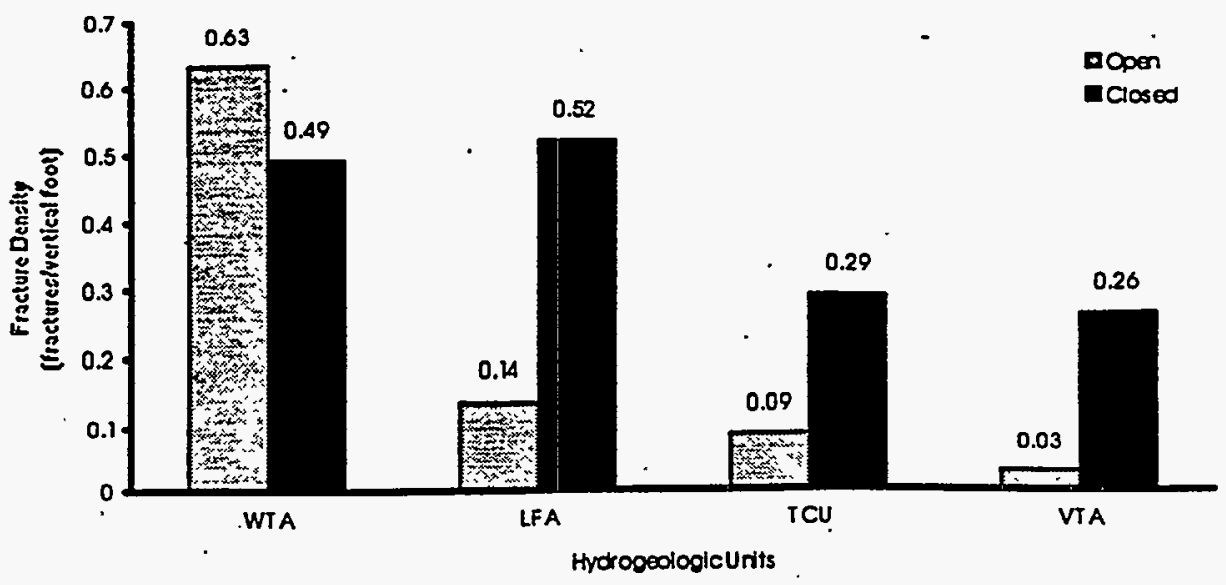

Figure 4-7a

Density of Open and Closed Fractures Relative to Hydrogeology for All Holes

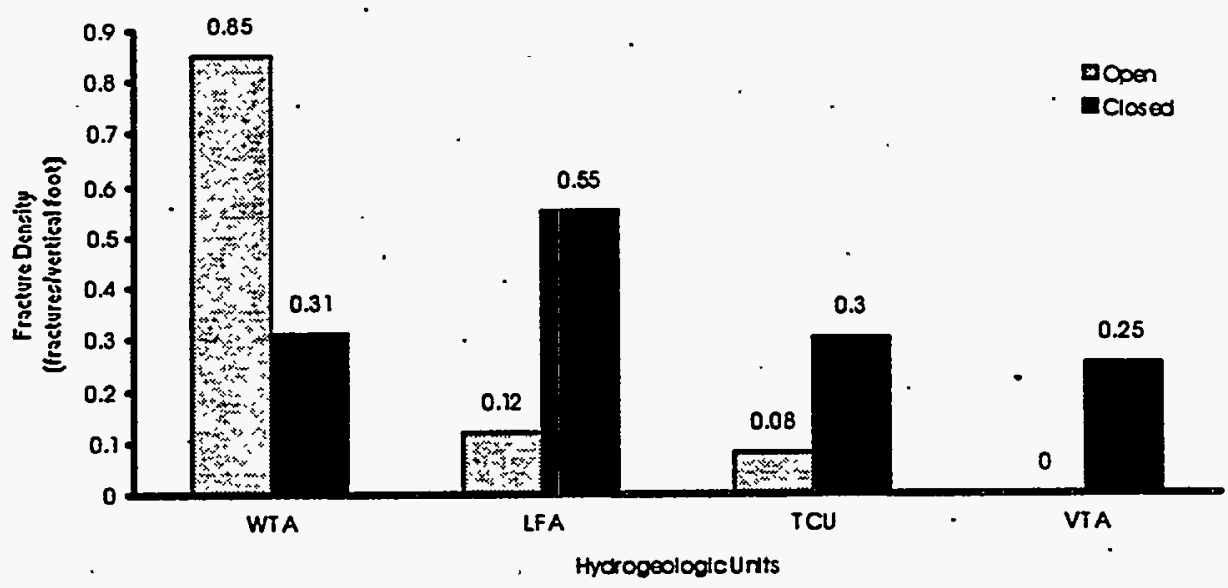

Figure 4-7b

Density of Open and Closed Fractures Relative to Hydrogeology for Pahute Mesa Holes Only

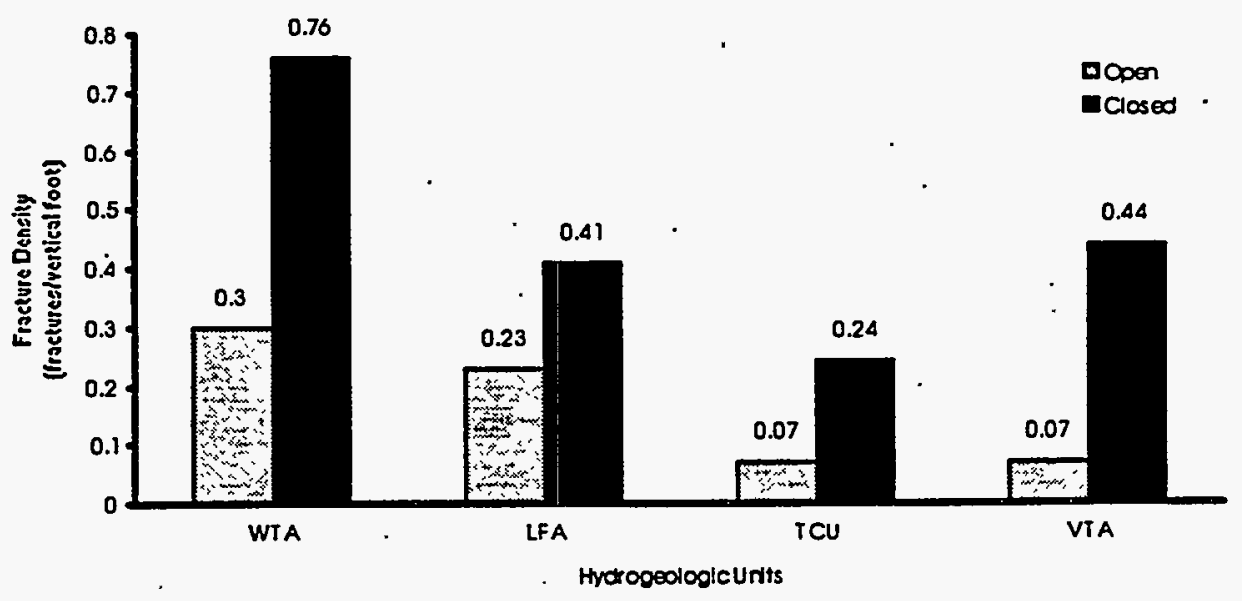

Figure 4-7c

Density of Open and Closed Fractures Relative to Hydrogeology for Area 18 Holes Only

Figure 4-7a-c

Summary of Fracture Density Relative to Hydrogeology 
Table 4-2

Fracture Aperture and Percent Open Data Summary

(Data Grouped by Hydrogeologic Units)

\begin{tabular}{|c|c|c|c|c|c|c|c|c|c|c|c|c|c|c|c|c|}
\hline & \multicolumn{8}{|c|}{ Average Aperture (millimeters) } & \multicolumn{8}{|c|}{ Percent Open Category } \\
\hline $\begin{array}{l}\text { Hydrogeo- } \\
\text { logic Units }\end{array}$ & UE-18r & UE-18t & UE-19x & $\begin{array}{l}\text { UE-20 } \\
\text { bh\#1 }\end{array}$ & $\begin{array}{c}\text { UE-20c } \\
\text { U-20c }\end{array}$ & $\begin{array}{c}\text { UE-20 } \\
\text { e\#1 }\end{array}$ & UE-20f & $\begin{array}{l}\text { Average } \\
\text { of Data }\end{array}$ & UE-18r & UE-18t & UE-19x & $\begin{array}{l}\text { UE-20 } \\
\text { bh } \# 1\end{array}$ & $\begin{array}{l}\text { UE-20c } \\
\text { U-20c }\end{array}$ & $\begin{array}{l}\text { UE-20 } \\
\text { e\#t1 }\end{array}$ & UE-20f & $\begin{array}{l}\text { Average } \\
\text { of Data }\end{array}$ \\
\hline $\begin{array}{l}\text { Vitric-Tuff } \\
\text { Aquifer } \\
\text { (NTA) }\end{array}$ & * & 0.95 . & * & - & - & - & - & 0.95 & - & $10-50$ & - & - & - & - & - & $10-50$ \\
\hline $\begin{array}{l}\text { Welded- } \\
\text { Tuff } \\
\text { Aquifer } \\
\text { (WTA) }\end{array}$ & 0.04 & 2.19 & 0.21 & - & 0.42 & - & 0.17 & 0.34 & $\begin{array}{c}1-10 \\
\text { and } \\
50-90\end{array}$ & $1-10$ & $50-100$ & - & $1-50$ & - & $50-99$ & 50-99 \\
\hline $\begin{array}{l}\text { Lava-Flow } \\
\text { Aquifer } \\
\text { (LFA) }\end{array}$ & 2.09 & - & 0.98 & * & * & 0.08 & 0.53 & 0.91 & $50-90$ & - & $1-50$ & - & - & $1-10$ & $1-50$ & $1-50$ \\
\hline $\begin{array}{l}\text { Tuff } \\
\text { Confining } \\
\text { Unit } \\
\text { (TCU) }\end{array}$ & 1.51 & - & 0.57 & 0.84 & 0.14 & 0.03 & 0.09 & 0.47 & $\begin{array}{c}50-90 \\
\text { and } \\
1-10\end{array}$ & - & $1-50$ & $1-50$ & $1-10$ & $1-10$ & $1-10$ & $1-50$ \\
\hline
\end{tabular}

1 UE-18t skews data set.

* Core representing unit was logged, but no open fractures recognized.

- Core representing unit not available from drill hole. 


\subsubsection{Mineralogy of Fracture Coatings}

Clay, iron and manganese oxides, calcite, and chalcedony occur most often in fractures within the WTA (Figure 4-8a). Interestingly, the LFA and TCU have very similar distributions of secondary minerals with zeolite, chalcedony, and iron and manganese oxides occurring most often (Figures 4-8b and 4-8c). Fractures within the VTA were observed to be coated most often with iron and manganese oxides, zeolite, clay, and euhedral quartz (Figure 4-8d). As mentioned previously, this fracture filling/coating mineral assemblage is similar to that observed at Yucca Mountain (Maldonado and Koether, 1983).

\subsection{Borehole Image Log Summary}

Many fractures cannot be discerned with either of the two borehole image logs (the FMS or the BHTV) analyzed for this fracture study. Fractures with very small apertures or those completely sealed with secondary minerals (i.e., closed fractures) may not present sufficient contrast to be imaged by these logging tools. Also, borehole rugosity due to breakouts or washouts may further impede interpretation. Absolute fracture density statistics from these logs will, therefore, not be valid. However, fracture orientation data are credible and are an important hydrologic parameter for the modelers. Because oriented core was not available for this study, fracture strike information from the borehole image logs could not be compared to core data. Fracture dip information was compared and was found to correlate very well.

\subsection{Comparison of Fracture Data, Available Hydrologic Test Data, and Caliper Logs}

Direct comparisons between available aquifer hydrologic tests and core fracture data is not straightforward. Typically only a small percentage of the borehole was cored, and the intermittent locations did not always correlate to the hydrologic test intervals. Where core and hydrologic test intervals did overlap, comparisons were generally good. Correlations were best in the TCUs where low fracture density and apertures seemed to correlate well with low testderived relative specific capacity values. Intervals found to be transmissive based on well aquifer tests typically correlated to LFA or WTA with higher fracture densities. Correlating high fracture density data from cores to hydrologic predictions was somewhat more difficult. Larger scale, in situ characteristics such as fracture interconnectivity and aquifer extent, which are not easily inferred from core alone, must be considered. 


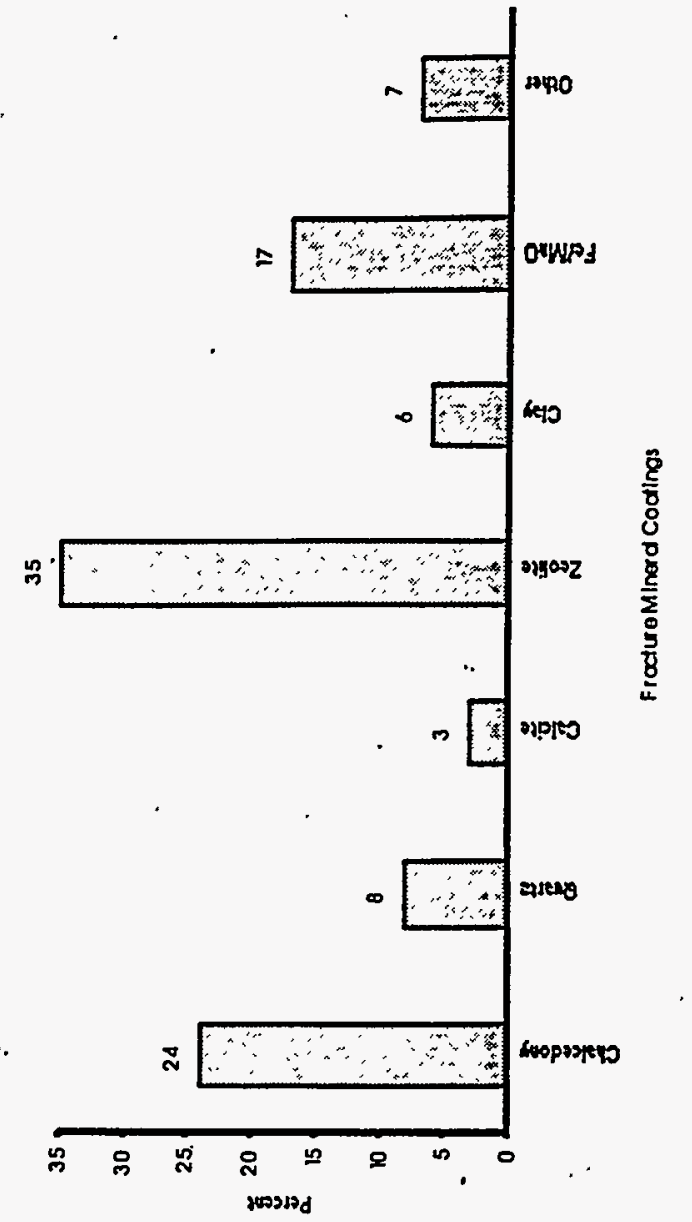

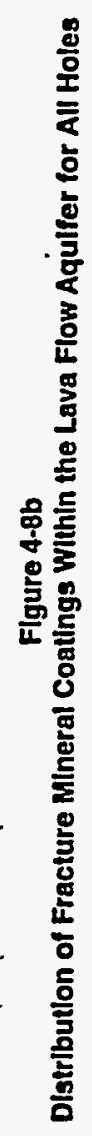
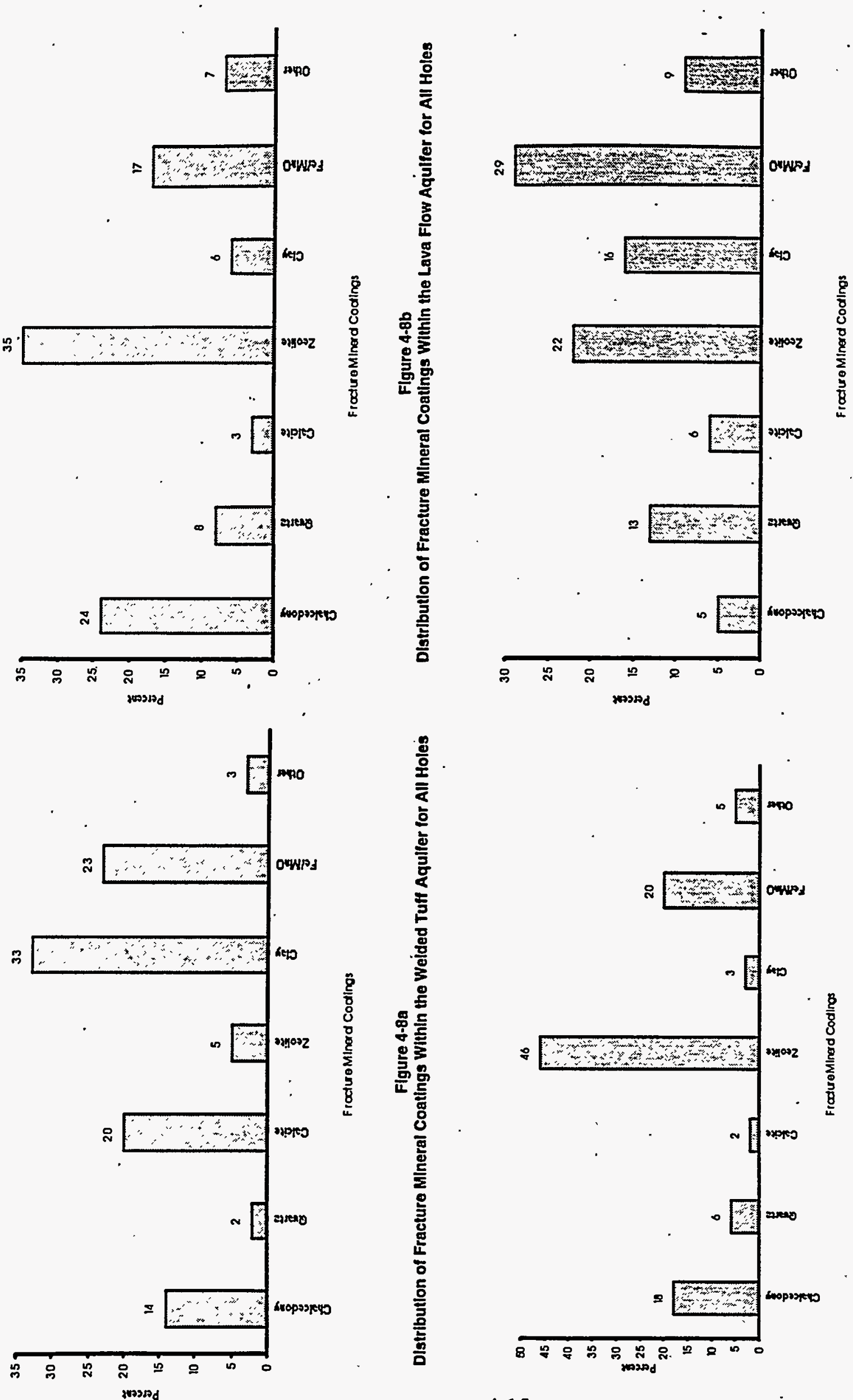

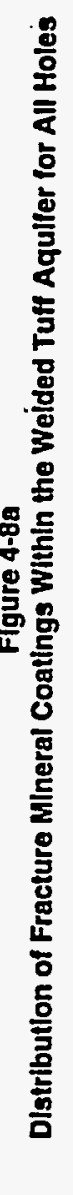

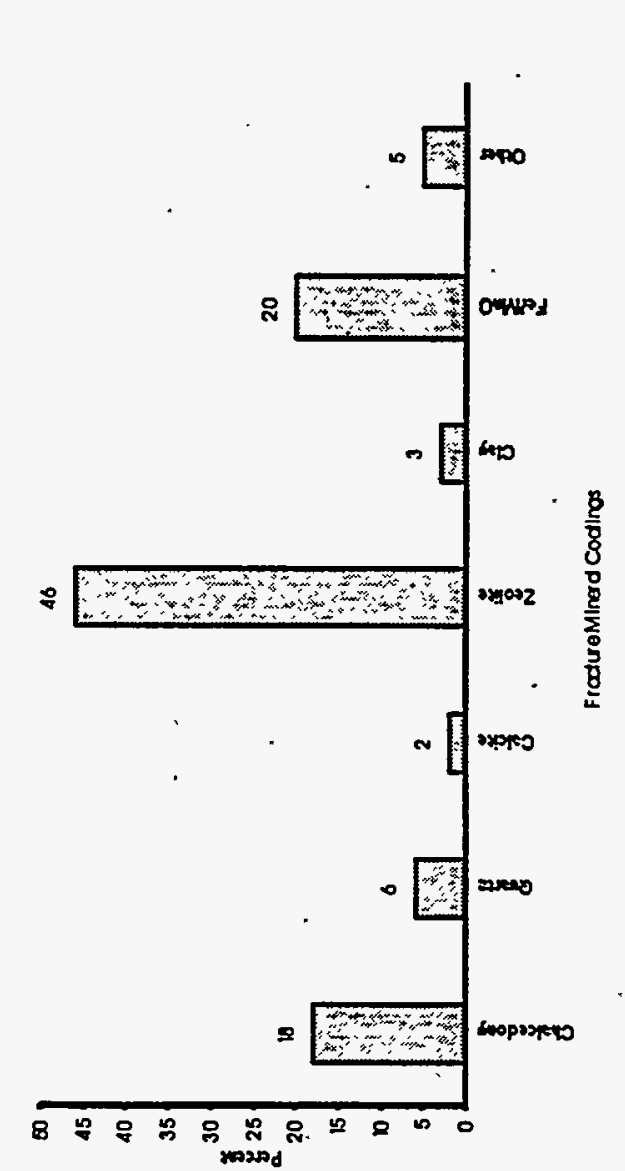

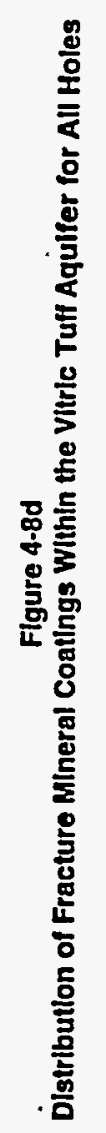

잉

ช

(1)

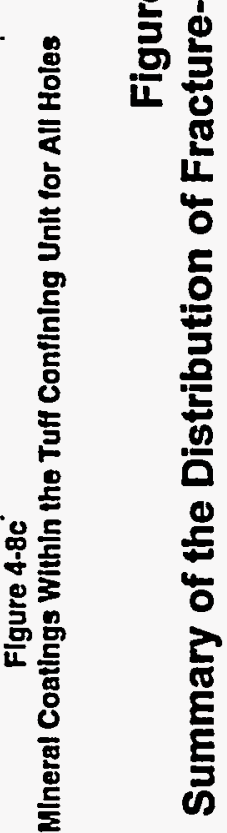

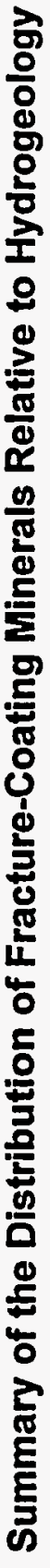


The caliper logs from each hole were compared with the corresponding fracture data. In general, there is an inconsistent correlation between fracture density and borehole irregularities, as indicated by the caliper logs. This finding emphasizes the complex relationships among the formation character, the borehole condition (effects on the in situ stress field, interaction between rock and drilling mud, etc.), and geophysical log tools such as the imaging and caliper tools. Though inconsistent, these logs are useful, but must be viewed from this broader, more allencompassing perspective. Also, it should be noted that the core holes chosen for this study had data only from the older three-arm caliper tools then available. It might be possible to glean a better indication of fractures using data obtained from the six-arm caliper tools in use today. 


\subsection{Summary and Recommendations for Further Study}

The end product of this data analysis effort is the compilation of an extensive data set for several attributes of fractures in volcanic cores from the Pahute Mesa/Timber Mountain area. These data are valuable for the assessment of hydrologic properties and other key parameters for flow and transport modeling such as diffusion, retardation, and conductivity. Other UGTA work planned for 1997 and 1998 will continue the hydrogeologic characterization of this study area, utilizing this and other data sets.

\subsection{General Conclusions}

The following general statements can be made concerning the data compiled and analyzed during this study:

- Most fracture attributes vary with respect to hydrogeologic unit and, consequently, with hydrostratigraphic unit.

- The mineralogy of fracture coatings was found to vary with respect to hydrogeologic unit, as well as with position relative to the water table.

- For various reasons, not all fractures are imaged by the Borehole Televiewer or the Formation Microscanner ${ }^{\mathrm{TM}}$ logs. However, most open fractures, presumably those which are hydrologically significant, are generally recorded. The imaging data, together with the orientation data, provide the hydrologist with valuable information required for modeling.

- An inconsistent correlation between fracture density and borehole irregularities, as indicated by the caliper logs, was noted.

- Comparisons between borehole aquifer tests and core fracture data were generally good. Low fracture density and low aperture, characteristic of tuff confining units, for example, correlate well with low test-derived relative specific capacity values, while intervals found to be transmissive typically correlated to lava-flow aquifers and welded-tuff aquifers with higher fracture densities. However, typically only a small percentage of each borehole was cored, and the cored intervals did not always match the hydrologic test intervals, making direct comparisons somewhat problematical.

- Because the fracture data from UE-18t is so different from that of the other Pahute Mesa drill holes, it is recommended that fracture statistics be presented in two data sets: data from the Pahute Mesa holes only, and data from the Area 18 holes only. 


\subsection{Recommendations for Further Study}

This fracture study highlighted several areas in which our present level of understanding could be improved. Those topics on which additional studies the authors feel would benefit the UGTA program are listed below.

- A change in fracture orientation with depth was noted on the borehole image logs from Exploratory Hole UE-18r and Well ER-20-5\#1. Presently, the origin of these anomalous fracture strikes is unexplained. Exploratory Hole UE-18r is located within the moat of the Timber Mountain caldera and thus could be considered to be in a different structural setting from the other holes. Well ER-20-5\#1 is located within the buried Silent Canyon caldera complex, as are the other holes in this study. Well ER-20-5\#1 is also located very near the locations of TYBO, an underground nuclear test, which could have affected the nearby in situ stress field.

- A fair amount of work has been done with regard to the mineralogy of fracture coatings, and this study adds to that body of data. Although useful preliminary observations are presented here, more detailed studies should be conducted. A better understanding of fracture-coating minerals is imperative for modeling the effects of diffusion and sorption, of radionuclides in groundwater.

- Limited amounts of core were available for the deeper hydrostratigraphic units. Additional fracture data should be obtained for these rocks in order to assemble a statistically credible data set.

- Hydrothermal alteration can drastically affect the hydraulic parameters of the geologic medium. For example, at Exploratory Hole UE-18t, located within the Timber Mountain moat, nearly all fractures in the denser volcanic rocks are completely sealed by secondary minerals, and the softer, originally more porous volcanic rocks are altered to clays. Such large-scale alteration could have profound effects on groundwater flow from the testing areas on Pahute Mesa. Although the general location for this hydrothermal alteration is presumably related to caldera structures, highly altered areas are presently not well defined. Further studies could greatly improve our confidence in predicting the nature and extent of this type of alteration. 


\subsection{References}

Adams, P.S. 1994. Written communication summarizing fractures, geology, and hydrogeologic tests at Exploratory hole UE-18r. Las Vegas, NV: IT Corporation.

Allen, Jim. 1993. Personal communication to IT Corp. regarding hydraulic test in Monitoring Well UE-20bh \#1, Las Vegas, NV.

Bechtel Nevada. 1996. "Well-site Core Handling," department procedure NTS-GEO-004. Las Vegas, NV.

Blankennagel, R.K., R.A. Young, J.B. Cooper, and H.A. Whitcomb. 1964. Summary of Ground Water Data Pertinent to Underground Construction and to Water-Supply Development, Pahute Mesa, Nevada Test Site, U.S. Geological Survey Technical Letter, Special Studies I-27. Denver, CO.

Blankennagel, R.K., and J.E. Weir, Jr. 1966. Summary of Ground Water Data Pertinent to Underground Construction and to Water-Supply Development, Pahute Mesa, Nevada Test Site, U.S. Geological Survey Technical Letter, Special Studies I-27., Supplement 2. Denver, CO.

Blankennagel, R.K., and J.E. Weir, Jr. 1973. Geohydrology of the Eastern Part of Pahute Mesa, Nevada Test Site, Nye County, Nevada, U.S. Geological Survey Professional Paper 712-B. Denver, CO.

Boyd, O.S., J.L. Wagoner, and R.C. Carlson. 1992. Site Characterization Report for HRMP Monitoring Well UE20bh-1, Nye County, Nevada Test Site. Livermore, CA: Lawrence Livermore National Laboratory.

Brikowski, T.J. 1991. The Hydrology of Underground Nuclear Tests: The Effect of CollapseChimney Formation, Desert Research Institute Publication No. 45090. Las Vegas, NV.

Byers, F.M., Jr., W.L. Hawkins, and D.C. Muller. 1981. Geology of Drill Hole UE18t and Area 18, Timber Mountain Caldera Moat, Nevada Test Site, U.S. Geological Survey Report USGS-474-312. Available only from U.S. Department of Commerce, National Technical Information Service, Springfield, VA 22161.

Carlos, B.A., D.L. Bish, and S.J. Chipera. 1990. Manganese Oxide Minerals in Fractures of the Crater Flat Tuff in Drill Core USW G-4, Yucca Mountain, Nevada, Los Alamos National Laboratory Report, LA-11787-MS. Los Alamos, NM.

Carr, W.J., F.M. Byers, and E.C. Jenkins. 1968. Geology of Drill Hole UE18r, Timber Mountain Caldera, Nevada Test Site, U.S. Geological Survey Technical Letter Special Studies-69. Denver, CO. 
Carr, W.J., F.M. Byers, Jr., and E.C. Jenkins. 1981. Geology of Drill Hole UE18r, Timber Mountain Caldera, Nevada Test Site, U.S. Geological Survey Report USGS-474-313. Available only from U.S. Department of Commerce, National Technical Information Service, Springfield, VA 22161.

Carroll, R.D. 1966. Preliminary Interpretation of Geophysical Logs, UE-20f, Pahute Mesa, Nevada Test Site, U.S. Geological Survey Technical Letter, Special Studies I-37, Supplement 1. Denver, CO.

DOE, see U.S. Department of Energy

Drellack, S.L., Jr, and L.B.Prothro. 1997. Descriptive Narrative for the Hydrogeologic Model of Western and Central Pahute Mesa Corrective Action Units. Interim documentation report for the UGTA project, submitted in support of the FY 1997 Pahute Mesa hydrogeological modeling effort. Las Vegas, NV: Bechtel Nevada.

Ekren, E.B., R.E. Anderson, P.P. Orkild, and E.N. Minrichs. 1966. "Geologic map for the Silent Butte, Quadrangle, Nye County, Nevada," U.S. Geological Survey Geologic Quadrangle Map GQ-493 Scale - 1:24,000. Denver, CO.

Ferguson, J.R., A.H. Cogbill, and R.G. Warren. 1994. "A Geophysical-Geological Transect of the Silent Canyon Caldera Complex, Pahute Mesa, Nevada." Journal of Geophysical Research, v. 99, no. 33: 4323-4339.

GeoTrans, Inc. 1995. A Fractured/Porous Media Model of Tritium Transport in the Underground Weapons Testing Areas, Nevada Test Site. Boulder, CO: GeoTrans, Inc.

Hoover, D.L. 1964. Preliminary Report on the Lithology, Hydrology and Physical Properties of the UE20e and the UE20e-1 Drill Holes, Area 20, Pahute Mesa, Nevada Test Site, U.S.. Geological Survey Report, Special Studies I-25. Denver, CO.

IT, see IT Corp.

IT Corp. 1995a. "Chain of custody," ITLV Standard Quality Practice No. ITLV-0402. Las Vegas, NV.

IT Corp. 1995b. "Sample handling, packaging and shipping," ITLV Standard Quality Practice No. ITLV-0403. Las Vegas, NV.

IT Corp. 1996a. Underground Test Area Fracture Analysis Report: Analysis of Fractures in Volcanic Cores from Pahute Mesa, Nevada Test Site. Draft. Las Vegas, NV.

IT Corp. 1996b. Regional Geologic Model Data Documentation Package (Phase I Data Analysis Documentation, Volume 1, Parts 1 and 2), ITLV/10972-181. Las Vegas, NV. 
Iyengar, Sam. 1996. "Fracture Mineralogy of Core Fragments from Nevada Test Site." Letter to K. Roberson, IT Corp., from Analytical Materials Laboratory, Santa Barbara, CA.

Laczniak, R.J., J.C. Cole, D.A. Sawyer, and D.A. Trudeau. 1996. Summary of Hydrogeologic Controls on Ground-Water Flow at the Nevada Test Site, Nye County, Nevada, U.S. Geological Survey Open-File Report 96-4109. Carson City, NV.

Maldonado, F. And S.L. Koether. 1983. Stratigraphy, Structure, and Some Petrographic Features of Tertiary Volcanic Rocks at the USW G-2 Drill Hole, Yucca Mountain, Nye County, Nevada, U.S. Geological Survey Open File Report 83-732. Denver, CO.

Paillet, F.L. 1991. "Flowmeter and Other Log Data for Borehole Ue-18r." U.S. Geological Survey Memorandum.

Paillet, F.L. U.S. Geological Survey. February 23, 1994. Letter to Pamela Adams, IT Corp, regarding reinterpretation of 1990 flowmeter data from Well UE18r. Denver, CO.

Prothro, L.B., and S.L. Drellack, Jr. 1997. Nature and Extent of Lava-Flow Aquifers Beneath Pahute Mesa, Nevada Test Site. DOE/NV/11718-156. Las Vegas, NV: Bechtel Nevada.

Reiner, S.R., G.L. Locke, and L.S. Robie. 1995. Ground-Water Data for the Nevada Test Site and Selected Other Areas in South-Central Nevada, 1992-93, U.S. Geological Survey Open File Report 95-160. Carson City, NV. .

Santos, E.S. 1964. Preliminary Report on the Lithology of Drill Hole UE20c, Pahute Mesa, Nevada Test Site, U.S. Geological Survey Technical Letter Special Studies I-26. Denver, CO.

U.S. Department of Energy, Nevada Operations Office. 1995. "Underground Test Area Operable Unit Geologic Cuttings and Core Collection and Management," DOE/NV Environmental Restoration Division Procedure No. ERD-UGTA-05-303, Rev. 0. Las Vegas, NV.

U.S. Department of Energy. 1994. United States Nuclear Tests, July 1945 through September 1992, DOE/NV-209 (Rev. 14). Las Vegas, NV.

Waddell, R.K, J.H. Robison, and R.K. Blankennagel. 1984. Hydrology of Yucca Mountain and Vicinity, Nevada-California Investigative Results Through Mid-1983, U.S. Geological Survey Water-Resources Investigation Report 84-4267. Denver, CO.

Warren, R.G. 1994. Informal document, Structural Elements and Hydrogeologic Units of the Southwestern Nevada Volcanic Field. Los Alamos, NM: Los Alamos National Laboratory.

Winograd, I.J. and William Thordarson. 1975. Hydrogeologic and Hydrochemical Framework, South-Central Great Basin, Nevada-California with Special Reference to the Nevada Test Site, U.S. Geological Survey Professional Paper 712-C. Denver, CO 
This page intentionally left blank.

$\downarrow$ 


\section{Appendix A \\ Mineralogy Information}

A1 Fracture Mineralogy Sample Descriptions

A2 Explanation of Fracture-Coating Categories

A3 Fracture Mineralogy of Core Fragments from Nevada Test Sites 


\section{A1.0 Fracture Mineralogy Sample Descriptions}

A total of twenty core-fragment samples was collected from Nevada Test Site drill holes UE-19x, UE-18r, UE-18t, UE-20f, UE-20e\#1, UE-20bh\#1, and UE-20c. The samples were collected for laboratory analysis of the mineral phases that coat fracture surfaces on the core fragments (Table A-1). In most cases, two or more mineral species are present on the fracture surface. Qualitative descriptions of the mineral phases on each sample, based on microscopic analysis of the fracture surfaces, are provided in the following log, which also includes instructions for the analytical laboratory. The descriptions present an initial hypothesis concerning the identity of each mineral and a rough estimate of the percentage of the fracture surface that is covered by each mineral phase. These crude identifications and estimates were intended to be used as guidelines by the analytical laboratory to aid in locating and/or differentiating between the minerals.

Section $\mathrm{A} 2$ contains an explanation of fracture-coating categories, and the results of mineralogical analyses by Analytical Materials Laboratory are presented in Section A3. 


\title{
Sample Collection Log
}

\author{
UE-19x
}

Eleven core fragment samples from core UE-19x were collected on January 18, 1996, by Sig Drellack (Bechtel Nevada [BN]), Lance Prothro (BN), Keith Roberson (IT Corp. [IT]), and Brad Schier (Daniel B. Stephens \& Assoc. [DBS\&A]).

\section{Depth Description of Material to be Analyzed/Notes}

$266 \mathrm{ft}$ Identify (ID) soft, waxy, white mineral with desiccation cracks, botryoidal in part (i/p) (zeolite?), covers $100 \%$ of fracture surface.

$459 \mathrm{ft}$ ID cream-colored, cryptocrystalline mineral covering $90 \%$ of surface; and very finely crystalline, white, opaque, hard $(>5)$ crystals distributed across $\sim 60 \%$ of surface (vapor-phase silicate?)

$781 \mathrm{ft}$ ID microcrystalline, clear, euhedral crystals covering entire fracture surface (Vapor-phase silicate?); plus larger colorless euhedral crystals (quartz?) ( 20\% coverage); plus flat, clear, colorless, striated rhombic crystals (sanidine ?) ( 20\% coverage); plus cream-colored, chalky mineral (zeolite?).

$901 \mathrm{ft} \quad \mathrm{ID}$ hard (>6), white, opaque, microcrystalline (silicate ?) coating $~ 35 \%$ of surface; and reddish-brown, soft zeolite (?) that covers $\sim 15 \%$ of the white mineral.

$911 \mathrm{ft}$ ID milky white, hard (>6), opaque, euhedial, striated crystals (as in 907') that cover $\sim 30 \%$ of surface; plus dark olive/gray, opaque, hard $(>6)$, striated crystals (poss. same as white mineral; plagioclase?) ( $10 \%$ surface coverage); plus any zeolites present. Also, if possible, ID the very fine specs of dark crystals (pyrite or other sulfide?) disseminated across fracture surface ( $.5 \%$ surface coverage).

$1,020 \mathrm{ft}$ ID translucent, botryoidal, hard $(\sim 7)$ silicate (chalcedony?) that covers $90 \%$ of surface; plus overlying orange-brown, soft, waxy material (zeolite?) that overlies $70 \%$ of the chalcedony.

1,241 ft Sample contains at least seven mineral phases for ID: white translucent calcite (10\%); gray translucent chalcedony (30\%); white \& cream-colored zeolites (15\%); hard black manganese oxide (?) (10\%); very soft black clay (5\%); \& brownish anhedral quartz $(40 \%)$.

$2,041 \mathrm{ft}$ ID thin, moderately hard $(\sim 5)$, translucent, milky white film coating $\sim 80 \%$ of fracture surface (one surface only). 
$2,142 \mathrm{ft}$ ID basal fracture coating (covers $\sim 80 \%$ of surface) of waxy, translucent, gray, moderately soft $(<4)$ zeolite or clay (contains desiccation cracks); plus overlying harder (5 to 6), cream-colored, opaque to translucent zeolite (?) that covers $40 \%$.

2,148 ft ID moderately hard (5 to 6), cream-colored, translucent zeolite (?) covering entire surface.

2,349 ft ID dark green/gray, waxy mineral (zeolite ?) coating entire fracture surface.

\section{UE-20f}

Two core fragment samples from core UE-20f were collected on January 18, 1996, by Sig Drellack (BN), Lance Prothro (BN), and Keith Roberson (IT).

\section{Depth Description of Material to be Analyzed/Notes}

$2,628 \mathrm{ft}$ ID finely sucrosic, hard, cream-colored mineral (chalcedony ?) coating $100 \%$ of surface; plus grayish brown, finely sucrosic quartz (?) coating $40 \%$ of first mineral's surface; plus tan powder zeolite (?) that covers $30 \%$ of surface (on top of first 2 minerals).

$3,704 \mathrm{ft}$ ID white zeolite (?) coating $\sim 90 \%$ of both fracture surfaces.

\section{UE-20e\#1}

One core fragment sample from core UE-20e\#1 was collected on January 31, 1996, by Lance Prothro (BN) and Keith Roberson (IT).

\section{Depth Description of Material to be Analyzed/Notes}

$4,501 \mathrm{ft}$ ID 2 mineral phases: cream-colored soft powder (zeolite?) covering $\sim 60 \%$ of fracture surface; plus white to colorless, translucent, hard ( $>6)$, equant, euhedral crystals (quartz or other silicate?) covering $40 \%$ of surface. 


\section{UE-20bh\#1}

One core fragment șample from core UE-20bh\#1 was collected on January 31, 1996, by Lance Prothro (BN) and Keith Roberson (IT).

\section{Depth Description of Material to be Analyzed/Notes}

$2,410 \mathrm{ft}$ ID 2 mineral phases: white, soft powder (zeolite?)that covers $100 \%$ of fracture surface and forms coherent crusts, fibrous "spider webs", and snowy masses; plus black dendrites (manganese oxide; pyrolusite?) that occur sporadically throughout the white powder.

\section{UE-18r}

One core fragment sample from core UE-18r was collected on January 31, 1996, by Lance Prothro (BN) and Keith Roberson (IT).

\section{Depth Description of Material to be Analyzed/Notes}

3,901 ft ID 4 mineral phases: black to dark gray, soft, fibrous, metallic mineral (resembles "steel wool") that covers $\sim 20 \%$ of surface; brown to gray, hard, crystalline silicate (?) with bladed to honeycomb morphology (covers $\sim 50 \%$ of surface); very fine, euhedral crystals (quartz?) covering bladed mineral ( $30 \%$ surface coverage); and light pink zeolite (?) covering $\sim 15 \%$ of surface.

\section{UE-18t}

Two core fragment samples from core UE-18t were collected on January 31; 1996, by Lance Prothro (BN) and Keith Roberson (IT).

\section{Depth Description of Material to be Analyzed/Notes}

$1,066 \mathrm{ft}$ ID 2 mineral phases: thick ( 8 to $10 \mathrm{~mm}$ ) white, soft, powdery clay or zeolite (?) that covers $100 \%$ of surface; and soft black/dark gray Mn oxide (?) interspersed within the white powder (coverage undetermined).

$1,251 \mathrm{ft}$ Sample contains 5 recognized mineral phases: thin black Mn-oxide (?) underlying all other mineral coatings; white to gray blades of chalcedony (?) covering $~ 100 \%$ of surface; dark brown to colorless, very finely sucrosic, very hard $(\sim 7)$, euhedral crystals (quartz?) precipitated on the chalcedony, also covering almost entire surface; soft white powdery mineral (zeolite?) covering $~ 10 \%$ of surface; and a second phase of amorphous white/gray chalcedony (?) covering $\sim 30$ of surface. 


\section{UE-20c}

Two core fragment samples were collected from core UE-20c on February 5, 1996, by Sig Drellack (BN), Lance Prothro (BN.), and Brad Schier (DBS\&A).

Depth Description of Material to be Analyzed/Notes

$2,851 \mathrm{ft}$ ID 2 mineral phases: $75 \%$ of surface is coated with tan to light brown very finely crystalline mineral (?) that appears to have been altered in places to a cream-colored clay or zeolite (?); $25 \%$ of the first mineral surface is coated by a soft, brownish black mineral (Mn oxide?) with a "splattered" distribution.

2,907 ft ID 2 mineral phases: thin coating or crust of light reddish tan, hard cryptocrystalline material (chalcedony?) covering $\sim 100 \%$ of surface; $\sim 75 \%$ of that material is covered by a gray/black, hard, crystalline mineral with a "micro-botryoidal" appearance (chalcedony stained by Mn-oxide or Fe-oxide?). 


\title{
A2.0 Explanation of Fracture-Coating Categories
}

\author{
Table A-1
}

Explanation of Fracture-Coating Categories

Used for Initial Visual Observation in this Study

\begin{tabular}{|c|c|c|}
\hline $\begin{array}{l}\text { FRACTURE } \\
\text { COATING } \\
\text { I.D. NUMBER }\end{array}$ & $\begin{array}{l}\text { SHORT } \\
\text { NAME }\end{array}$ & DESCRIPTION \\
\hline 0 & None & $\begin{array}{l}\text { No visible mineral coating along any portion of the fracture } \\
\text { surface(s). }\end{array}$ \\
\hline 1 & Chalcedony & $\begin{array}{l}\text { Typical cryptocrystalline variety of quartz. May occur as a } \\
\text { thin coating or in thicker botryoidal forms. }\end{array}$ \\
\hline 2 & $\begin{array}{l}\text { Euhedral } \\
\text { Quartz }\end{array}$ & $\begin{array}{l}\text { Typically as a sucrosic, finely crystalline coating. Less } \\
\text { common as relatively large, }>1 \mathrm{~mm} \text { in size, well formed } \\
\text { quartz crystals. May occur as individual crystals scattered } \\
\text { along a fracture face, or as clusters partially or completely } \\
\text { lining vugs. }\end{array}$ \\
\hline 3 & Calcite & $\begin{array}{l}\text { Several varieties possible: from microcrystalline coatings } \\
\text { to clusters of "sparry" euhedral crystals. }\end{array}$ \\
\hline 4 & Zeolites & $\begin{array}{l}\text { Soft, massive; clay-like, commonly cream to tan or green } \\
\text { in color. }\end{array}$ \\
\hline 5 & Clay & $\begin{array}{l}\text { Typical clay properties including small desiccation cracks; } \\
\text { may include some zeolites. White to brown, massive, soft. }\end{array}$ \\
\hline 6 & $\begin{array}{l}\text { a. Fe Oxides } \\
\text { b. Mn Oxides }\end{array}$ & $\begin{array}{l}\text { Reddish-brown to black (with reddish streak) to less } \\
\text { common yellowish (limonite), usually occurs as a stain } \\
\text { or thin veneer. } \\
\text { b. Black, varies from spots to dendrites, to thin coating. }\end{array}$ \\
\hline 7 & $\begin{array}{r}\text { Unknown } \\
\text { mineral(s) }\end{array}$ & Could not determine identity by visual observation. \\
\hline 8 & Vapor phase & $\begin{array}{l}\text { Vapor-phase mineralization; product of late-stage cooling } \\
\text { and degassing. High-temperature quartz and feldspar } \\
\text { mineralogy. . Commonly exhibits a sucrosic texture. Also } \\
\text { included is a clear, flat, tubular, striated variety. }\end{array}$ \\
\hline 9 & $\begin{array}{l}\text { Unknown } \\
\text { silicate }\end{array}$ & $\begin{array}{l}\text { Includes white, opaque, hard, massive variety; sometimes } \\
\text { grading into larger striated microcrystalline crystals. }\end{array}$ \\
\hline 10 & Fault gouge. & $\begin{array}{l}\text { Soft, pulverized material. Although clay-like, may be } \\
\text { differentiated from the clay or zeolite categories by coarser } \\
\text { texture, often with matrix inclusions. }\end{array}$ \\
\hline
\end{tabular}




\section{A3.0 Fracture Mineralogy of Core Fragments from Nevada}

Test Sites

The following pages present the results of mineralogical analyses conducted by Analytical Materials Laboratory on twenty samples from Pahute Mesa core holes (see sample descriptions in Section A1.0). 
This page intentionally left blank. 


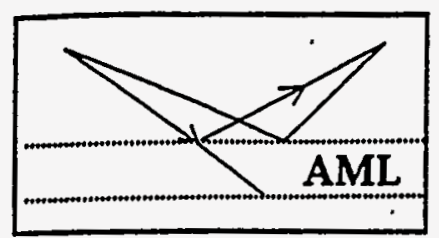

Mr. Keith Roberson

IT Corporation

4330 South Valley View

Suite 114

Las Vegas, Nevada 89103 - 4047

Sam lyengar, Ph.D

Technical Director
March 1, 1996
3463 State Street, \#349 • Santa Barbara, CA 93105

Phone: (805) 682-0051 • Fax: (805) 687-2297

\section{Experts in X-Ray Analysis}

\section{ANalytical Materials Laboratory}

Dear Keith

Enclosed please find a report on the mineralogy of 2. samples you submitted. Please review this and call me if you have any questions or concerns

Sincerely,

Sam lyengar

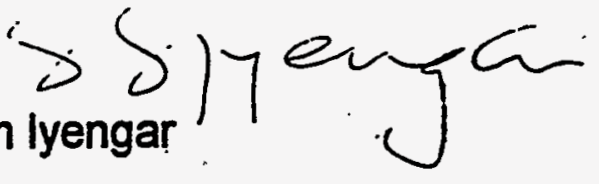


This page intentionally left blank. 
Fracture Mineralogy of Core Fragments from Nevada Test Sites

Introduction:

Twenty core samples from Nevada Test Site were submitted for mineralogical analysis. Mineralogy of materials on the fracture surfaces were characterized using X-ray powder diffraction (XRD), electron microprobe and polarizing microscope. The following report summarizes the findings:

\section{Materials:}

The fracture surfaces from the following twenty core samples were characterized:

Core \#

UE - 19x
Depth (ft.)

266

459

781

901

911

1020

1241

2041

2142

2148

2349

UE - $20 f$

2628

3704

UE - 20e\#1

4501

UE - 20bh\#1

2410

UE - 18r

3901

UE - 18t

1066

1251

UE - 20C

2851

2907 


\section{Methods:}

Materials on the fracture surfaces were scrapped or hand picked for the analysis. For $X R D$ analysis, they were ground in an agate mortor and pestle, and were loaded in a sample holder. They were examined using a Scintag diffractometer and were scanned from 5 to 65 degrees two-theta using Cu K-alpha radiation at $45 \mathrm{kV}$ and $40 \mathrm{ma}$. The resulting pattems collected on a computer were matched with the reference standards for various inorganic and organic materials stored in the JCPDS data base

For Microprobe analysis, materials were applied to a spectrographically pure carbon black and vacuum coated with about $300 \mathrm{~A}$ carbon. They were bombarded with $20 \mathrm{kV}$ electrons in a Cameca Electron beam Microprobe Analyzer causing the emission of characteristic $X$-rays for each element. These $X$-rays were detected and identified by the integral energy dispersive optics of the X-ray spectrometer. The counts were collected simultaneously for 1000 seconds and quantified with the aid of the associated Sun computer using a fundamental parameters iteration and comparison to known standards. The unknowns and the standards were run under identical conditions at a take-off angle of $\mathbf{4 2}$ degrees.

For Clay analysis, the powder samples were suspended and shaken in distilled water to promote dispersion. The time required to separate $<2$ uM fraction was calculated from the Stocks law and the suspensions were allowed to stand for appropriate time. The supernatant (with colloids). solution was decanted into a separate beaker. The process of adding water and settling was continued till the supernatant became clear.

A portion of the clay suspension in the beaker was used to make oriented clay mounts on a Millipore filter. The suspensions were filtered through a 45 uM filter paper on a Millipore filter set-up using vacuum. They were then washed thoroughly with distilled water to remove excess salts. The clay cake on the filter paper was transferred, while still wet, onto a glass slide and kept in an ethylene glycol chamber for 24 hours. A drop of glycol was placed on the edge of each slide before placing them in the chamber. The oriented mounts were heated to $150 \mathrm{C}$ and $550 \mathrm{C}$ in a muffle fumace to confirm the presence of smectite and chlorite, respectively.

Oriented and glycolated clay mounts were scanned from 2 to 45 degrees two-theta on a Scintag diffractometer using Cu K-alpha radiation at $40 \mathrm{kV}$ and $45 \mathrm{ma}$. The heated clay mounts were scanned from 3 to 17 degrees two theta using the same setup described above 
For petrographic work, grain mounts of powders were prepared in canadabalsam. They were examined using a Leitz petrographic microscope with an image processor. Thermal images of interested samples were prepared.

Results and Discussion:

The powder XRD patterns for the samples are shown in attached figures and the mineralogy is summarized in table 1. In most cases, the minerals are arranged in decreasing abundance. A NIST silicon standard was also analyzed and is shown in figure 21 along with a stick pattern for the reference standard (PDF \# 27 - 1402) from the JCPDS data base. A certificate is also enclosed.

The non-clay minerals found are quartz (chert, chalcedony), cristobalite, tridymite, feldspars (both K- and plagioclase), calcite and Ilmenite In most of the figures, a stick pattern for quartz (PDF \# 33 - 1161) from the Joint committee for Powder Diffraction Standards. (JCPDS) data base is shown.

Two major zeolite minerals - Cliroptilolite (PDF \# 39 - 1383) and Mordenite (PDF \# 29 - 1257) - are present in some of the samples. Stick patterns for these two are shown in the XRD patterns for the samples that contain them.

The major clay mineral components are smectite, followed by small amounts of mica (or illite). One sample (UE - 19x @ 2349 ft.) contained a clay mineral, palygorskite. Another sample (UE - 18r @ $3901 \mathrm{ft}$.) contained an Interstratified smectite-mica mineral called rectorife. Its presence is evident from the appearance of integral super-lattice " $d$ " spacings.

The presence of smectite is confirmed by analyzing oriented mounts of clay fraction ( $<2$ or 5 microns) that has been glycolated. An increase (expansion) in " $d$ " spacing confirms its presence. In most of the figures, the clay XRD scan is superimposed on the corresponding scans for the whole (powdered) rock. In sample UE - 19x @ $911 \mathrm{ft}$, grains were picked from the wide "holes" on the fracture surface and analyzed. It was mostly smectite.

For microprobe analysis, selected grains were hand picked under a stereomicroscope and mounted on a carbon tape. They were analyzed using a 2 3 microns electron beam: When Mn oxides coatings was suspected, the same procedure was followed and confirmed its presence. 
Table 1

\begin{tabular}{|c|c|c|c|c|}
\hline \multirow[t]{2}{*}{ Core \# } & \multirow{2}{*}{$\begin{array}{l}\text { Depth } \\
\text { (ft) }\end{array}$} & \multicolumn{3}{|c|}{ Mineralogy } \\
\hline & & Minerals present & comments & Figures \\
\hline$U E-19 x$ & 266 & - Smectite & $\begin{array}{l}\text { Expands on } \\
\text { glycolation }\end{array}$ & Figure 1 \\
\hline \multirow[t]{5}{*}{. } & 459 & $\begin{array}{l}\text { - Quartz } \\
\text { - Na and K - Feldspars } \\
\text { - Mica } \\
\text { - Smectite } \\
\end{array}$ & $\begin{array}{l}\text { Creamy and white } \\
\text { crystals are Si rich }\end{array}$ & $\begin{array}{l}\text { Figs. } 2 \text { \& } 2 a \\
\text { (XRD) } \\
\text { Fig. 2b } \\
\text { (probe) }\end{array}$ \\
\hline & 781 & $\begin{array}{l}\text { - Quartz } \\
\text { - Na and K - Feldspars } \\
\text { - Clinoptilolite } \\
\text { - Smectite \& mica }\end{array}$ & $\begin{array}{l}\text { Microcrystalline } \\
\text { grains were chert } \\
\text { and Si rich. } \\
\text { Creamy - clinop. }\end{array}$ & $\begin{array}{l}\text { Figs } 3 \& \text { \&a } \\
\text { (XRD) } \\
\text { Figs } 3 b \text { \& 3c } \\
\text { (probe) }\end{array}$ \\
\hline & 901 & $\begin{array}{l}\text { - Quartz } \\
\text { - Tridymite } \\
\text { - Smectite } \\
\text { - Feldspars } \\
\end{array}$ & Mostly Si rich & $\begin{array}{l}\text { Fig } 4 \text { (XRD) } \\
\text { Fig } 4 a \text { (probe) }\end{array}$ \\
\hline & 911 & $\begin{array}{l}\text { - Quartz } \\
\text { - Feldspars - Ca \& Na } \\
\text { - Smectite } \\
\text { - Clinoptilolite (trace) } \\
\text { - Ilmenite (trace) }\end{array}$ & $\begin{array}{l}\text { Milky white \& olive } \\
\text { gray grains are Si } \\
\text { rich with Al, Mg - } \\
\text { zeolite \& clay. } \\
\text { Dark crystals - } \\
\text { llmenite }\end{array}$ & $\begin{array}{l}\text { Figs. } 5 \& 5 a \\
\text { (XRD) } \\
\text { Figs } 5 b \text { \& } 5 c \\
\text { (probe) }\end{array}$ \\
\hline & 1020 & $\begin{array}{l}\text { - Smectite } \\
\text { - Cristobalite } \\
\text { - Quartz (chert) } \\
\text { - Feldspars } \\
\end{array}$ & $\begin{array}{l}\text { Chert grains } \\
\text { coated with clay }\end{array}$ & $\begin{array}{l}\text { Figs } 6 \text { \& } 6 a \\
\text { (XRD) } \\
\text { Fig } 6 b \text { (probe) } \\
\text { Fig } 6 c \text { (petro.) }\end{array}$ \\
\hline . & 1241 & $\begin{array}{l}\text { - Cristobalite } \\
\text { - Smectite } \\
\text { - Clinoptilolite } \\
\text { - Feldspars } \\
\text { - Calcite } \\
\text { - Mica }\end{array}$ & $\begin{array}{l}\text { White translucent, } \\
\text { chaicedony grains } \\
\text { are Si rich crist. } \\
\text { grains } \\
\text { White \& cream } \\
\text { colored grains - } \\
\text { zeolite } \\
\text { Black clay - } \\
\text { smectite with Mn } \\
\text { coating }\end{array}$ & $\begin{array}{l}\text { Figs } 7 \& 7 a \\
\text { (XRD) } \\
\text { Figs 7b, 7c \& } \\
7 d \text { (probe) } \\
\text { Fig 7e - } \\
\text { (petro) }\end{array}$ \\
\hline
\end{tabular}


Table 1 (Contd.)

\begin{tabular}{|c|c|c|c|c|}
\hline \multirow[t]{2}{*}{ Core \# } & \multirow{2}{*}{$\begin{array}{l}\text { Depth } \\
\text { (ft) }\end{array}$} & \multicolumn{3}{|c|}{ Mineralogy } \\
\hline & & minerals present & comments & Figures \\
\hline \multirow[t]{4}{*}{ UE - 19x } & 2041 & - Clinoptilolite & & $\begin{array}{l}\text { Figure } 8 \\
\text { (XRD) }\end{array}$ \\
\hline & 2142 & $\begin{array}{l}\text { - Clinoptilolite } \\
\text { - Smectite } \\
\text { - Mica (trace) } \\
\text { - Tridymite } \\
\end{array}$ & $\begin{array}{l}\text { Waxy crystals are } \\
\text { Clinoptilolite } \\
\text { Creamy grains- } \\
\text { clay }\end{array}$ & $\begin{array}{l}\text { Figs. } 9 \& 9 a \\
\text { (XRD) }\end{array}$ \\
\hline & 2148 & $\begin{array}{l}\text { - Clinoptilolite } \\
\text { - Quartz } \\
\text { - Tridymite } \\
\text { - Mica } \\
\end{array}$ & $\theta$ & $\begin{array}{l}\text { Figs } 10 \\
\text { (XRD) }\end{array}$ \\
\hline & 2349 & $\begin{array}{l}\text { - Clinoptilolite } \\
\text { - Palygorskite }\end{array}$ & & $\begin{array}{l}\text { Fig 11 \& 11a } \\
\text { (XRD) }\end{array}$ \\
\hline \multirow[t]{2}{*}{ UE - $20 f$} & 2628 & $\begin{array}{l}\text { - Clinoptilolite } \\
\text { - Cristobalite } \\
\text { - Quartz } \\
\text { - Tridymite } \\
\text { - Mica }\end{array}$ & $\begin{array}{l}\text { Grayish white \& } \\
\text { tan grains are } \mathrm{Si} \\
\text { rich with Al and } \mathrm{K} \text { - } \\
\text { - zeolite \& Fd }\end{array}$ & $\begin{array}{l}\text { Figs. } 12 \\
\text { (XRD) } \\
\text { Figs 12a } \\
\text { (probe) }\end{array}$ \\
\hline & 3704 & - Mordenite & & $\begin{array}{l}\text { Figs } 13 \\
\text { (XRD). }\end{array}$ \\
\hline $\begin{array}{l}\text { UE - } \\
20 \mathrm{e} \# 1\end{array}$ & 4501 & $\begin{array}{l}\text { - Clinoptilolite } \\
\text { - Quartz } \\
\text { - Feldspars } \\
\text { - Mica } \\
\end{array}$ & & $\begin{array}{l}\text { Figs } 14 \\
\text { (XRD) }\end{array}$ \\
\hline $\begin{array}{l}\text { UE - } \\
\text { 20bh\#1 }\end{array}$ & 2410 & - Mordenite & $\begin{array}{l}\text { Black dendrites are } \\
\text { Mn oxide coatings }\end{array}$ & $\begin{array}{l}\text { Figs 15\& 15a } \\
\text { (XRD } \\
\text { Fig 15b } \\
\text { (probe) }\end{array}$ \\
\hline UE - 18r & 3901 & $\begin{array}{l}\text { - Interstratified } \\
\text { Smectite-mica } \\
\text { (Rectorite) } \\
\text { Quartz }\end{array}$ & $\begin{array}{l}\text { Honeycomb and } \\
\text { pink materials are } \\
\text { same - clay } \\
\text { Steel wool-clay } \\
\& \text { cherts coated } \\
\text { with Mn oxides }\end{array}$ & $\begin{array}{l}\text { Figs 16 \& 16a } \\
\text { (XRD) } \\
\text { Figs 16b, 16c } \\
\text { (probe) } \\
\text { Fig 16d } \\
\text { (petro) }\end{array}$ \\
\hline
\end{tabular}


Table 1 (Contd.)

\begin{tabular}{|c|c|c|c|c|}
\hline \multirow[t]{2}{*}{ Core \# } & \multirow{2}{*}{$\begin{array}{l}\text { Depth } \\
\text { (ft) }\end{array}$} & \multicolumn{3}{|c|}{ Mineralogy } \\
\hline & & minerals present & comments & Fiaures \\
\hline \multirow[t]{2}{*}{ UE - 18t } & 1066 & $\begin{array}{l}\text { - Smectite } \\
\text { - Quartz }\end{array}$ & $\begin{array}{l}\text { Black - clay coated } \\
\text { with Mn oxides }\end{array}$ & $\begin{array}{l}\text { Figs. } 17 \& 17 a \\
\text { (XRD) } \\
\text { Figs 17b \& } \\
17 c \text { (probe) }\end{array}$ \\
\hline & 1251 & $\begin{array}{l}\text { - Quartz } \\
\text { - Smectite } \\
\text { - Mica (trace) }\end{array}$ & $\begin{array}{l}\text { Underlying black } \\
\text { vein - Chalcedony } \\
\text { coated with Mn } \\
\text { oxides } \\
\text { Euhedral grains - } \\
\text { Qtz. } \\
\text { White powdery - } \\
\text { clay }\end{array}$ & $\begin{array}{l}\text { Figs. 18 \& 18a } \\
\text { (XRD) } \\
\text { Fig 18b } \\
\text { (probe) }\end{array}$ \\
\hline \multirow[t]{2}{*}{ UE - 20c } & 2851 & - Quartz & $\begin{array}{l}\text { Tan to light brown } \\
\text { grains - Qtz or } \\
\text { chert coated with } \\
\text { clay \& Mn oxides. }\end{array}$ & $\begin{array}{l}\text { Figs 19 \& 19a } \\
\text { (XRD) } \\
\text { Fig 19b } \\
\text { (probe) }\end{array}$ \\
\hline & 2907 & $\begin{array}{l}\text { - Quartz } \\
\text { - K-, Na- and Ca } \\
\text { Feldspars } \\
\text { - Mica }\end{array}$ & $\begin{array}{l}\text { Light reddish } \\
\text { brown grains-Qtz } \\
\text { or chert coated } \\
\text { with fine grained } \\
\text { mica clay } \\
\text { "micro-botryoidal" } \\
\text { looking grains - Si } \\
\text { grains coated with } \\
\text { Mn oxides }\end{array}$ & $\begin{array}{l}\text { Fig 20 \&.20a } \\
\text { (XRD) } \\
\text { Fig 20b } \\
\text { (petro.) } \\
\text { Probe figures } \\
\text { not shown. }\end{array}$ \\
\hline
\end{tabular}




\section{Appendix B}

Annotated Bibliography of Nevada Test Site Fracture Data 


\section{B1.0 Introduction}

Table B-1 is an annotated bibliography that lists (alphabetically by author) pertinent documents published by the Yucca Mountain Project and the Nevada Test Site (NTS) Containment Program regarding fracture characteristics in volcanic rocks. These documents contain fracture data for saturated and unsaturated volcanic rocks at Yucca Mountain and Pahute Mesa, and generally address field- and laboratory-derived fracture parameter data that are relevant to groundwater flow and contaminant transport modeling.

These references were compiled in 1996 from the libraries of four NTS organizations: the Yucca Mountain Project (YMP), U.S. Department of Energy (DOE/NV), Bechtel Nevada (BN), and IT Corporation (IT). Key words used in the searches included aperture, conductivity, core, fracture, geohydrologic, geomechanic, hydrogeologic, hydrologic, orientation, porosity, permeability, rock mechanics, spacing, televiewer, Yucca Mountain, and various Area 25 well names.

In addition to library database key word and well name searches, the following bibliographies identified pertinent documents:

Glanzman, V.M. 1991. Bibliography of Publications Related to the Yucca Mountain Site Characterization Project prepared by U.S. Geological Survey Personnel Through April 1991, USGS Open-File Report 91-341. Denver, CO.

Glanzman, V.M. 1992. Bibliography of Publications Prepared by U.S. Geological Survey Personnel Under Cooperative Programs with the U.S. Department of Energy and Predecessor Agencies, 1957-1991, with Emphasis on Nuclear Testing Programs, USGS Open-File Report 92-502. Denver, CO.

Office of Scientific and Technical Information. 1992. Yucca Mountain Site Characterization Project Bibliography, January-June 1992, An Update, U.S. Department of Energy, DOE/OSTI--3406 (Suppl.3) (Add.1), DE92016339.

Russell, C.E. 1988. Annotated Bibliography of the Physical Data of Rainier Mesa and Yucca Mountain, NWPO-TR-012089. Las Vegas, NV: Desert Research Institute.

Documents that appraise special situations and focus on validating measurement methodologies or developing flow models are not included here. As a result, the amount of raw data presented in the reports is frequently limited. Nonetheless, this bibliography lists each report containing raw fracture data even where the data are scant. Documents without raw fracture data have generally been omitted. 
Table B-1

Annotated Bibliography of Nevada Test Site Fracture Data (Page 1 of 19)

\begin{tabular}{|c|c|c|c|}
\hline Source & $\begin{array}{l}\text { Tracking } \\
\text { Number }\end{array}$ & Reference & Summary of Relevant Data \\
\hline IT Library & 4682 & $\begin{array}{l}\text { Anderson, L.A. 1994. Water Permeability and Related Rock } \\
\text { Properties Measured on Core Samples from the Yucca } \\
\text { Mountain USW GU-3/G-3 and USW G-4, USGS Open-File } \\
\text { Report 92-201. }\end{array}$ & $\begin{array}{l}\text { Porosity and permeability values compared } \\
\text { with volcanic stratigraphy for } 226 \text { core } \\
\text { samples }\end{array}$ \\
\hline IT Library & 0154 & $\begin{array}{l}\text { Anderson, L.A. 1991. Results of Rock Property } \\
\text { Measurements Made on Core Samples from Yucca Mountain } \\
\text { Boreholes, Nevada Test Site, Nevada, Part 1. Boreholes } \\
\text { UĖ25A-4, -5, -6, and -7, Part 2. Borehole UE25P\#1, USGS } \\
\text { Open-File Report 90-474. }\end{array}$ & $\begin{array}{l}\text { Porosity and permeability values reported for } \\
\text { volcanic and carbonate core samples }\end{array}$ \\
\hline IT Library & 1175 & $\begin{array}{l}\text { Anderson, L.A. 1984. Rock Property Measurements on } \\
\text { Large-Volume Core Samples from Yucca Mountain USW GU- } \\
\text { 3/G-3 and USW G-4 Boreholes, Nevada Test Site, Nevada, } \\
\text { USGS Open-File Report 84-552. }\end{array}$ & $\begin{array}{l}\text { Porosity values compared with rock density } \\
\text { and volcanic stratigraphy for } 144 \text { core } \\
\text { samples }\end{array}$ \\
\hline IT Library & 1174 & $\begin{array}{l}\text { Anderson, L.A. 1981. Rock Property Analysis of Core } \\
\text { Samples from the Yucca Mountain UE25a-1 Borehole, Nevada } \\
\text { Test Site, Nevada, USGS Open-File Report 81-1338. }\end{array}$ & $\begin{array}{l}\text { Porosities and hydraulic conductivities } \\
\text { compared with volcanic stratigraphy for } 58 \\
\text { core samples }\end{array}$ \\
\hline IT Library & 0891.01 & $\begin{array}{l}\text { Barton, C.C. 1991. Abstract: Fractal Scaling of Fracture } \\
\text { Networks in Rock, USGS Open-File Report } 91-125\end{array}$ & $\begin{array}{l}\text { Spatial distributions of outcrop fracture traces } \\
\text { quantified to establish fractal dimension }\end{array}$ \\
\hline IT. Library & 0819 & $\begin{array}{l}\text { Barton, C.C., W.R. Page, and T.L. Morgan. 1989. Fractures } \\
\text { in Outcrops in the Vicinity of Drill Hole USW G-4, Yucca } \\
\text { Mountain, Nevada, USGS Open-File Report 89-92. }\end{array}$ & $\begin{array}{l}\text { Strike, dip, and surface roughness of } 5,000 \\
\text { outcrop fractures reported }\end{array}$ \\
\hline
\end{tabular}


Table B-1

Annotated Bibliography of Nevada Test Site Fracture Data

(Page 2 of 19)

\begin{tabular}{|c|c|c|c|}
\hline Source & $\begin{array}{l}\text { Tracking } \\
\text { Number }\end{array}$ & Reference & Summary of Relevant Data \\
\hline IT Library & 4735 & $\begin{array}{l}\text { Barton, C.C. and P.A. Hsieh. 1989.. "Physical and Hydrologic- } \\
\text { Flow Properties of Fractures," In the Field Trip Guidebook } \\
\text { T385 0-87590-650-8, Presented at the 28th International } \\
\text { Geological Congress, Las Vegas, Nevada; Zion Canyon, Utah; } \\
\text { Grand Canyon, Arizona; and Yucca Mountain, Nevada. } \\
\text { Washington, DC: American Geophysical Union. }\end{array}$ & $\begin{array}{l}\text { Fracture characteristics discussed generally } \\
\text { and mapping of Yucca Mountain pavements } \\
\text { described }\end{array}$ \\
\hline DOE/NV Library & Journal & $\begin{array}{l}\text { Barton, C.C. and E. Larsen. 1985. "Fractal Geometry of Two- } \\
\text { Dimensional Fracture Networks at Yucca Mountain, } \\
\text { Southwestern Nevada," In Proceedings of the International } \\
\text { Symposium on Fundamentals of Rock Joints, Bjorkliden, } \\
\text { Lapland, Sweden, September 15-20. }\end{array}$ & $\begin{array}{l}\text { Fracture orientation, trace lengths, and } \\
\text { networks presented }\end{array}$ \\
\hline IT Library & 0012 & $\begin{array}{l}\text { Bentley, C.B. 1984. Geohydrologic Data for Test Well USW } \\
\text { G-4, Yucca Mountain Area, Nye County, Nevada, USGS } \\
\text { Open-File Report 84-063. }\end{array}$ & $\begin{array}{l}\text { Borehole flow survey, packer test, and pump } \\
\text { test results reported }\end{array}$ \\
\hline IT Library & .0013 & $\begin{array}{l}\text { Bentley, C. B., J.H. Robison, and R.W. Spengler. } 1983 . \\
\text { Geohydrologic Data for Test Well USW H-5, Yucca Mountain } \\
\text { Area, Nye County, Nevada, USGS Open-File Report 83-853. }\end{array}$ & $\begin{array}{l}\text { Pump test, borehole flow survey, and packer- } \\
\text { injection test results reported }\end{array}$ \\
\hline IT Library & 0018 & $\begin{array}{l}\text { Blankennagel, R.K. and J.E. Weir, Jr. 1973. Geohydrology of } \\
\text { the Eastern Part of Pahute Mesa, Nevada Test Site, Nye } \\
\text { County, Nevada, Geological Survey Professional Paper 712-B. }\end{array}$ & $\begin{array}{l}\text { Fracture frequency in ash-fall, nonwelded } \\
\text { ash-fall, and welded tuffs reported }\end{array}$ \\
\hline DOE/NV Library & $\begin{array}{l}\text { LA-UR-86- } \\
1413\end{array}$ & $\begin{array}{l}\text { Broxton, D.E. and B.A. Carlos. 1986. "Zeolitic Alteration and } \\
\text { Fracture Fillings," In Silicic Tuffs at a Potential Nuclear Waste } \\
\text { Repository, Yucca Mountain, Nevada, USA LA-UR-86-1413, } \\
\text { Presented at the Fifth International Water-Rock Interaction } \\
\text { Symposium, Reykjavik, Iceland, August. }\end{array}$ & Fracture fillings discussed \\
\hline
\end{tabular}


Table B-1

Annotated Bibliography of Nevada Test Site Fracture Data

(Page 3 of 19)

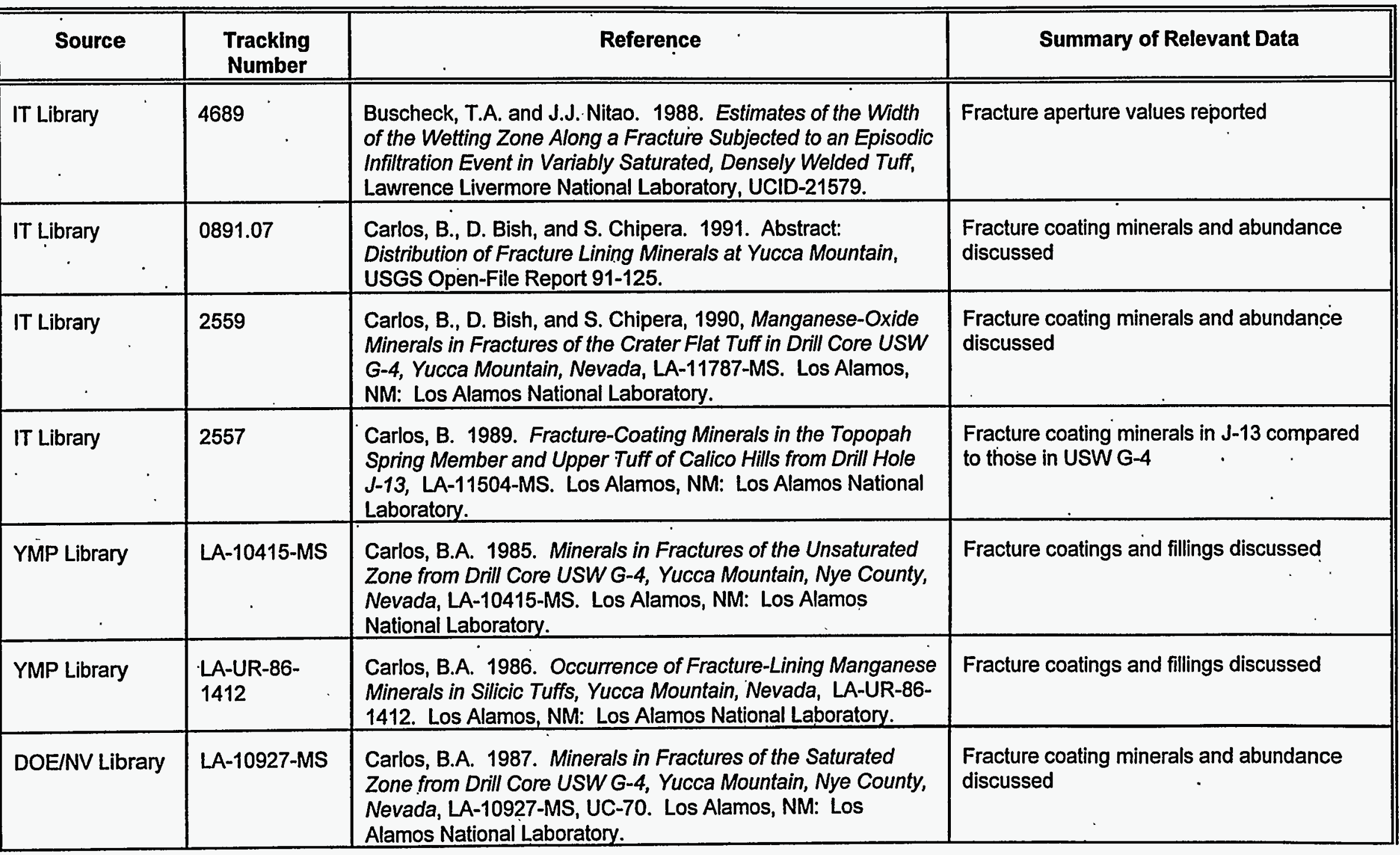


Table B-1

\section{Annotated Bibliography of Nevada Test Site Fracture Data}

(Page 4 of 19)

\begin{tabular}{|c|c|c|c|}
\hline Source & $\begin{array}{l}\text { Tracking } \\
\text { Number }\end{array}$ & Reference & Summary of Relevant Data \\
\hline IT Library & 1234 & $\begin{array}{l}\text { Carlson, R.C. and J.L. Wagoner. 1991. U20be Site } \\
\text { Characteristics Report, CP 91-18. Lawrence Livermore } \\
\text { National Laboratory. }\end{array}$ & Fracture frequency reported \\
\hline IT. Library & 1177 & $\begin{array}{l}\text { Carr, M.D., S.J. Waddell, G.S. Vick, J.M. Stock, S.A. Monsen, } \\
\text { A.G. Harris, B.W. Cork, and F.M. Byers, Jr. 1986. Geology of } \\
\text { Drill Hole UE25p\#1: A Test Hole Into Pre-Tertiary Rocks Near } \\
\text { Yucca Mountain, Southern Nevada, USGS Open-File Report } \\
\text { 86-175. }\end{array}$ & $\begin{array}{l}\text { Fracture data from oriented core (Paleozoic } \\
\text { section) and acoustic borehole televiewer log } \\
\text { results (Tertiary and Paleozoic sections) } \\
\text { reported. Fractures described }\end{array}$ \\
\hline BN Library & $\begin{array}{l}\text { USGS Tech. } \\
\text { Letter SS I-37, } \\
\text { Supp. } 1 .\end{array}$ & $\begin{array}{l}\text { Carroll, R.D. 1966. Preliminary Interpretation of Geophysicall } \\
\text { Logs, UE-2Of, Pahute Mesa, Nevada Test Site, U.S. } \\
\text { Geological Survey Technical Letter, Special Studies I-37, } \\
\text { Supplement 1. Denver, CO. . }\end{array}$ & $\begin{array}{l}\text { Rock properties at UE-20f, including, log } \\
\text { response, hydrology and inferred fracture } \\
\text { zones }\end{array}$ \\
\hline IT Library & 1309 & $\begin{array}{l}\text { Clark, S. and D. McArthur. 1986. U20av 624.8- } m \text { Site } \\
\text { Characteristics Report, CP 86-55. Lawrence Livermore } \\
\text { National Laboratory. }\end{array}$ & Location of cooling joints indicated \\
\hline IT Library. & 1312 & $\begin{array}{l}\text { Clark, S., R. Newmark, and D. McArthur. 1987. U20ar 544.7- } \\
m \text { Site Characteristics Report, CP 87-26. Lawrence Livermore } \\
\text { National Laboratory. }\end{array}$ & Location of cooling joints indicated \\
\hline IT Library & 1310 & $\begin{array}{l}\text { Clark, S. and G. Pawloski. 1986. U20at 544.1-m Site } \\
\text { Characteristics Report, CP 86-56. Lawrence Livermore } \\
\text { National Laboratory. }\end{array}$ & Fracture frequency and fault attitude indicated \\
\hline IT Library & 1376 & $\begin{array}{l}\text { Clark, S. and G. Pawloski. 1985. U20aq 549-m Preliminary } \\
\text { Site Characteristics Summary, CP 85-114. Lawrence } \\
\text { Livermore National Laboratory. }\end{array}$ & $\begin{array}{l}\text { Location of cooling joints indicated and cross- } \\
\text { referenced with cooling joints at U20al }\end{array}$ \\
\hline IT Library & 1375 & $\begin{array}{l}\text { Clark, S. and C. Schmidt. 1986. U20ap 635- } m \text { Site } \\
\text { Characteristics Report, CP } 86-48 \text {. Lawrence Livermore } \\
\text { National Laboratory. }\end{array}$ & $\begin{array}{l}\text { Location and attitude of faults and fractures } \\
\text { indicated }\end{array}$ \\
\hline
\end{tabular}


Table B-1

Annotated Bibliography of Nevada Test Site Fracture Data

(Page 5 of 19)

\begin{tabular}{|c|c|c|c|}
\hline Source & $\begin{array}{l}\text { Tracking } \\
\text { Number } \\
\end{array}$ & Reference & Summary of Relevant Data \\
\hline IT Library & 1211 & $\begin{array}{l}\text { Clark, S. and J. Wagoner. 1986. U19an 615.7-m Preliminary } \\
\text { Site Characteristics Summany, CP 86-13. Lawrence } \\
\text { Livermore National Laboratory. }\end{array}$ & Location of cooling joints indicated \\
\hline IT Library & $\begin{array}{c}0011 \\
\vdots \\
\end{array}$ & $\begin{array}{l}\text { Craig, R.W. and K.A. Johnson. 1984. Geohydrologic Data for } \\
\text { Test Well UE-25p\#1, Yucca Mountain Area, Nye County, } \\
\text { Nevada, USGS Open-File Report 84-450. }\end{array}$ & $\begin{array}{l}\text { Borehole flow survey, pump test, and packer- } \\
\text { injection test results reported }\end{array}$ \\
\hline IT Library & 1548 & $\begin{array}{l}\text { Craig, R.W. and R.L. Reed. 1991. Geohydrology of Rocks } \\
\text { Penetrated by Test Well USW H-6, Yucca Mountain, Nye } \\
\text { County, Nevada, USGS Water-Resources Investigations } \\
\text { Report } 89-4025 \text {. }\end{array}$ & $\begin{array}{l}\text { Borehole flow survey, pump test, and packer- } \\
\text { injection test results reported }\end{array}$ \\
\hline IT Library & 0014 & $\begin{array}{l}\text { Craig, R.W., R.L. Reed, and R.W. Spengler. } 1983 . \\
\text { Geohydrologic Data for Test Well USW H-6, Yucca Mountain } \\
\text { Area, Nye County, Nevada, USGS Open-File Report 83-856. }\end{array}$ & Pump test results reported \\
\hline IT Library & 0064 & $\begin{array}{l}\text { Craig, R.W. and J.H. Robison. 1984. Geohydrology of Rocks } \\
\text { Penetrated by Test Well UE-25p\#1, Yucca Mountain, Nye } \\
\text { County, Nevada, USGS Water-Resources Investigations } \\
\text { Report 84-4248. }\end{array}$ & $\begin{array}{l}\text { Borehole flow survey, pump test, and packer- } \\
\text { injection test reported }\end{array}$ \\
\hline IT Library & 0891.06 & $\begin{array}{l}\text { Diehl, S.F., M.P. Chornack, H.S. Swolfs, and J.K. Odum. } \\
\text { 1991. Abstract: Fracture Studies in the Welded Grouse } \\
\text { Canyon Tuff: Laser Drift of the G-Tunnel Underground } \\
\text { Facility, Rainier Mesa, Nevada Test Site, Nevada, USGS } \\
\text { Open-File Report } 91-125 .\end{array}$ & $\begin{array}{l}\text { Orientation of prominent fractures and } \\
\text { microfractures for Laser Drift presented }\end{array}$ \\
\hline IT Library & 4686 & $\begin{array}{l}\text { Ellis, W.L. and H.S. Swolfs. 1983. Preliminary Assessment of } \\
\text { In-Situ Geomechanical Characteristics in Drill Hole USW G-1, } \\
\text { Yucca Mountain, Nevada, USGS Open-File Report 83-401. }\end{array}$ & Fracture frequency identified \\
\hline
\end{tabular}




\section{Table B-1}

\section{Annotated Bibliography of Nevada Test Site Fracture Data}

\section{(Page 6 of 19)}

\begin{tabular}{|c|c|c|c|}
\hline Source & $\begin{array}{l}\text { Tracking } \\
\text { Number }\end{array}$ & Reference & Summary of Relevant Data \\
\hline IT Library & 0176 & $\begin{array}{l}\text { Erickson, J.R. and R.K. Waddell. 1985. Identification and } \\
\text { Characterization of Hydrologic Properties of Fractured Tuff } \\
\text { Using Hydraulic and Tracer Tests - Test Well USWH-4, } \\
\text { Yucca Mountain, Nye County, Nevada, USGS Water- } \\
\text { Resources Investigations Report 85-4066. }\end{array}$ & $\begin{array}{l}\text { USW H-4 televiewer log results reported, } \\
\text { including fracture frequency and orientation } \\
\text { and an estimation of fracture porosity }\end{array}$ \\
\hline IT Library & 0159 & $\begin{array}{l}\text { Flint, L.E. and A.L. Flint. 1990. Preliminary Permeability and } \\
\text { Water-Retention Data for Nonwelded and Bedded Tuff } \\
\text { Samples, Yucca Mountain Area, Nye County, Nevada, USGS } \\
\text { Open-File Report 90-569. }\end{array}$ & $\begin{array}{l}\text { Saturated permeability, relative permeability, } \\
\text { water retention properties, grain density, bulk } \\
\text { density, and porosity data reported for } 73 \\
\text { core samples }\end{array}$ \\
\hline IT Library & 2730 & $\begin{array}{l}\text { Geldon, A.L. 1992. Preliminary Hydrogeologic Assessment of } \\
\text { Boreholes UE-25c \#1, UE-25c \#2, and UE-25c \#3, Yucca } \\
\text { Mountain, Nye County, Nevada, USGS Water-Resources } \\
\text { Investigations Report 92-4016. }\end{array}$ & Fracture density and orientation reported \\
\hline IT Library & 4579 & $\begin{array}{l}\text { GeoTrans, Inc. 1995. A Fracture/Porous Media Model of } \\
\text { Tritium Transport in the Underground Weapons Testing Areas, } \\
\text { Nevada Test Site, Boulder, Colorado. }\end{array}$ & $\begin{array}{l}\text { Values used in the model for matrix porosity, } \\
\text { aperture width, fracture spacing, fracture } \\
\text { frequency, hydraulic conductivity, and velocity } \\
\text { reported }\end{array}$ \\
\hline BN Library & SAND82-1043 & $\begin{array}{l}\text { Hadley, G.R. 1984. Water Transport through Welded Tuff, } \\
\text { SAND82-1043. Sandia National Laboratories. }\end{array}$ & $\begin{array}{l}\text { Laboratory experiments on welded tuff core } \\
\text { imbibing and drying, capillary action }\end{array}$ \\
\hline IT Library & 0441 & $\begin{array}{l}\text { Haldeman, W.R., Y. Chuang, T.C. Rasmussen, and D.D. } \\
\text { Evans. 1991. "Laboratory Analysis of Fluid Flow and Solute } \\
\text { Transport Through a Fracture Embedded in Porous Tuff, In } \\
\text { Water Resources Research, Volume 27, No. 1, pp. 53-65. } \\
\text { Tucson, AZ: University of Arizona, Department of Hydrology } \\
\text { and Water Resources. }\end{array}$ & $\begin{array}{l}\text { Laboratory experiments conducted to } \\
\text { determine flow and transport properties of a } \\
\text { block of fractured porous tuff described }\end{array}$ \\
\hline
\end{tabular}


Table B-1

Annotated Bibliography of Nevada Test Site Fracture Data

(Page 7 of 19)

\begin{tabular}{|c|c|c|c|}
\hline Source & $\begin{array}{l}\text { Tracking } \\
\text { Number }\end{array}$ & Reference & Summary of Relevant Data \\
\hline IT Library & 1176 & $\begin{array}{l}\text { Healy, J.H., S.H. Hickman, M.D. Zoback, and W.L. Ellis: } 1984 . \\
\text { Report on Televiewer Log and Stress Measurements in Core } \\
\text { Hole USW-G1, Nevada Test Site, December 13-22, 1981, } \\
\text { USGS Open-File Report 84-15. }\end{array}$ & Fracture occurrence and orientation reported \\
\hline IT Library & 1374 & $\begin{array}{l}\text { Howard, N.W. and J.L. Wagoner. 1985. U20ao 548.6-m } \\
\text { Preliminary Site Characteristics Summary, CP 85-74. } \\
\text { Lawrence Livermore National Laboratory. }\end{array}$ & Location of cooling joints indicated \\
\hline BN Library & & $\begin{array}{l}\text { Howard, T.M. and E. Larsen. 1984. Preliminary Study of } \\
\text { Joints in the Upper Lithophysical Subunit of the Tiva Canyon } \\
\text { Member of the Paintbrush Tuff Formation Near USW-G4, } \\
\text { Yucca Mountain, Nevada. Fenix \& Scisson, Inc. }\end{array}$ & $\begin{array}{l}\text { Fracture occurrence, orientation, and } \\
\text { attributes reported }\end{array}$ \\
\hline IT Library & & $\begin{array}{l}\text { IT Corporation. 1995. Wells ER-6-1 and ER-6-2 Core } \\
\text { Fracture Analyses and Geophysical Log Comparisons, } \\
\text { DOE/NV/10972--XX. }\end{array}$ & $\begin{array}{l}\text { Fracture occurrence, orientation, and } \\
\text { attributes in carbonate and argillite rocks at } \\
\text { Southern Yucca Flat }\end{array}$ \\
\hline IT Library & 4685 & $\begin{array}{l}\text { Janecky, D.R., R.S. Rundberg, M. Ott, and A. Mitchell. } 1990 . \\
\text { Update Report on Fracture Flow in Saturated Tuff: Dynamic } \\
\text { Transport Task for the Nevada Nuclear Waste Investigations, } \\
\text { LA-11957-MS. Los Alamos, NM: Los Alamos National } \\
\text { Laboratory. }\end{array}$ & $\begin{array}{l}\text { Porosity, roughness, fractal dimension, and } \\
\text { aperture values presented for a block of } \\
\text { fractured tuff removed from the surface of } \\
\text { Yucca Mountain }\end{array}$ \\
\hline YMP Library & SAND84-2642 & $\begin{array}{l}\text { Klavetter, E.A. and R.R. Peters. 1986. Estimation of } \\
\text { Hydrologic Properties of An Unsaturated, Fractured Rock } \\
\text { Mass, SAND84-2642. Sandia National Laboratory. }\end{array}$ & $\begin{array}{l}\text { Fracture aperture, conductivity, density, } \\
\text { porosity, compressibility, and bulk } \\
\text { conductivity reported }\end{array}$ \\
\hline IT Library & 0805 & $\begin{array}{l}\text { Klavetter, E.A. and R.R. Peters. 1986. Fluid Flow in a } \\
\text { Fractured Rock Mass, SAND85-0855C. Sandia National } \\
\text { Laboratory. }\end{array}$ & $\begin{array}{l}\text { Continuum model to evaluate water } \\
\text { movement through fractured rock developed }\end{array}$ \\
\hline
\end{tabular}


Table B-1

Annotated Bibliography of Nevada Test Site Fracture Data

(Page 8 of 19)

\begin{tabular}{|c|c|c|c|}
\hline Source & $\begin{array}{l}\text { Tracking } \\
\text { Number }\end{array}$ & Reference & Summary of Relevant Data \\
\hline IT Library & 0157 & $\begin{array}{l}\text { Kume, J. and D. Hammermeister. 1990. Geohydrologic Data } \\
\text { from Test Hole USW UZ-7, Yucca Mountain Area, Nye } \\
\text { County, Nevada, USGS Open-File Report 88-465. }\end{array}$ & Porosity data for drive core samples reported \\
\hline IT Library & 0158 & $\begin{array}{l}\text { Kume, J. and D. Hammermeister. 1991. Geohydrologic Data } \\
\text { from Drill-Bit Cuttings and Rotary Cores from Test Hole USW } \\
\text { UZ-13, Yucca Mountain Area, Nye County, Nevada, USGS } \\
\text { Open-File Report 90-362. }\end{array}$ & $\begin{array}{l}\text { Water content values reported for core } \\
\text { samples }\end{array}$ \\
\hline IT Library & 0019 & $\begin{array}{l}\text { Lahoud, R.G., D.H. Lobmeyer, and M.S. Whitfield, Jr. } 1984 . \\
\text { Geohydrology of Volcanic Tuff Penetrated by Test Well UE- } \\
25 \text { b\#1, Yucca Mountain, Nye County, Nevada, USGS Water- } \\
\text { Resources Investigations Report 84-4253. }\end{array}$ & $\begin{array}{l}\text { Shear fracture frequency and aquifer test } \\
\text { results reported }\end{array}$ \\
\hline IT Library & 4679 & $\begin{array}{l}\text { Lin, M., M.P. Hardy, and S.J. Bauer, J.F.T. 1992.. Fracture } \\
\text { Analysis and Rock Quality Designation Estimation for the } \\
\text { Yucca Mountain Site Characterization Project, SAND92-0449. }\end{array}$ & $\begin{array}{l}\text { Fracture frequency, orientation, roughness, } \\
\text { fillings, and coatings reported }\end{array}$ \\
\hline IT Library & 4678 & $\begin{array}{l}\text { Lin, W. and W. Daily. 1984. Transport Properties of Topopah } \\
\text { Spring Tuff, UCRL-53602. Lawrence Livermore National } \\
\text { Laboratory. }\end{array}$ & $\begin{array}{l}\text { Permeability of fractured Topopah Spring tuff } \\
\text { measured during dehydration - rehydration } \\
\text { experiments }\end{array}$ \\
\hline BN Library & SAND85-2701 & $\begin{array}{l}\text { Lin, Y.T., M.S. Tierney, S. Sinnock, editors. 1986. Preliminary } \\
\text { Estimates of Groundwater Travel Time and Radionuclide } \\
\text { Transport at the Yucca Mountain Repository Site, SAND85- } \\
\text { 2701. Albuquerque, NM: Sandia National Laboratories. }\end{array}$ & $\begin{array}{l}\text { Addresses vertical groundwater flow, } \\
\text { effective porosity and hydraulic conductivity. }\end{array}$ \\
\hline IT Library & 0195 & $\begin{array}{l}\text { Lobmeyer, D.H. 1986. Geohydrology of Rocks Penetrated by } \\
\text { Test Well USW G-4, Yucca Mountain, Nye County, Nevada, } \\
\text { USGS Water-Resources Investigations Report 86-4015. }\end{array}$ & $\begin{array}{l}\text { Flow survey, packer-injection, and pump test } \\
\text { results reported }\end{array}$ \\
\hline
\end{tabular}


Table B-1

Annotated Bibliography of Nevada Test Site Fracture Data

(Page 9 of 19)

\begin{tabular}{|c|c|c|c|}
\hline Source & $\begin{array}{l}\text { Tracking } \\
\text { Number }\end{array}$ & Reference & Summary of Relevant Data \\
\hline IT Library & 0010 & $\begin{array}{l}\text { Lobmeyer, D.H., M.S. Whitfield, Jr., R.R. Lahoud, and L. } \\
\text { Bruckheimer. 1983. Geohydrologic Data for Test Well UE-. } \\
25 b \# 1, \text { Nevada.Test Site, Nye County, Nevada, USGS Open- } \\
\text { File Report 83-855. }\end{array}$ & $\begin{array}{l}\text { Matrix porosity, pore saturation, matrix } \\
\text { hydraulic conductivity, shear fracture } \\
\text { frequency, and aquifer test results reported }\end{array}$ \\
\hline IT Library & 4684 & $\begin{array}{l}\text { Loskot, C.L. and D.P. Hammermeister. 1992. Geohydrologic } \\
\text { Data from Test Holes UE-25 UZ\#4 and UE-25 UZ\#5, Yucca } \\
\text { Mountain Area, Nye County, Nevada, USGS Open-File Report } \\
90-369 \text {. }\end{array}$ & $\begin{array}{l}\text { Water content values reported for core and } \\
\text { cuttings samples }\end{array}$ \\
\hline IT Library & 0789 & $\begin{array}{l}\text { Maldonado, F. and S.L. Koether. 1983. Stratigraphy, } \\
\text { Structure, and Some Petrographic Features of Tertiary } \\
\text { Volcanic Rocks at the USW G-2 Drill Hole, Yucca Mountain, } \\
\text { Nye County, Nevada, USGS Open-File Report 83-732. }\end{array}$ & $\begin{array}{l}\text { Fracture frequency, dip, fillings, coatings, and } \\
\text { fracture zones reported }\end{array}$ \\
\hline BN Library & SAND84-1697 & $\begin{array}{l}\text { Martinez, M.J. 1988. Capillany-Driven Flow in a Fracture } \\
\text { Located in a Porous Medium, SAND84-1697. Albuquerque, } \\
\text { NM: Sandia National Laboratories. }\end{array}$ & $\begin{array}{l}\text { Hydraulic lab experiments with several rock } \\
\text { units common at Yucca Mountain }\end{array}$ \\
\hline IT Library & 1233 & $\begin{array}{l}\text { McKague, H.L. and J.R. Hearst. 1991. U20ax Site } \\
\text { Characteristics Report 21st Anniversary Issue, CP 91-121. } \\
\text { Lawrence Livermore National Laboratory }\end{array}$ & Fracture frequency reported \\
\hline IT Library & 1304 & $\begin{array}{l}\text { McKague, L., J. Hearst, and B. McKinnis. 1989. U20bc Site } \\
\text { Characteristics Report, CP 89-48. Lawrence Livermore } \\
\text { National Laboratory. }\end{array}$ & Fracture frequency reported \\
\hline IT Library & 0759 & $\begin{array}{l}\text { McKague, H.L. and R.L. Newmark. 1989. U20bd Site } \\
\text { Characteristics Report, CP 89-167. Lawrence Livermore } \\
\text { National Laboratory. }\end{array}$ & Fracture frequency reported \\
\hline
\end{tabular}




\section{Table B-1 \\ Annotated Bibliography of Nevada Test Site Fracture Data}

(Page 10 of 19)

\begin{tabular}{|c|c|c|c|}
\hline Source & $\begin{array}{l}\text { Tracking } \\
\text { Number } \\
\end{array}$ & Reference & Summary of Relevant Data \\
\hline IT Library & 0004 & $\begin{array}{l}\text { Montazer, P. and W.E. Wilson. 1984. Conceptual Hydrologic } \\
\text { Model of Flow in the Unsaturated Zone, Yucca Mountain, } \\
\text { Nevada, USGS Water-Resources Investigations Report 84- } \\
\text { 4345. }\end{array}$ & $\begin{array}{l}\text { Hypothetical model for flow-through layers of } \\
\text { fractured volcanics presented }\end{array}$ \\
\hline IT Library & 0787 & $\begin{array}{l}\text { Moore, D.E., C.A. Morrow, and J.D. Byerlee. } 1984 . \\
\text { Permeability and Fluid Chemistry Studies of the Topopah } \\
\text { Spring Member of the Paintbrush Tuff, Nevada Test Site: Part } \\
\text { II, USGS Open-File Report 84-848. }\end{array}$ & $\begin{array}{l}\text { The effect of pore pressure, sample } \\
\text { orientation, and flow direction on permeability } \\
\text { and pore fluid chemistry evaluated }\end{array}$ \\
\hline IT Library & 4738 & $\begin{array}{l}\text { Morgan, T.L. 1984. "Fracture Characterization of the Tiva } \\
\text { Canyon Member, Paintbrush Tuff, Nevada," Masters Thesis, } \\
\text { Colorado State University, Fort Collins, Colorado. }\end{array}$ & $\begin{array}{l}\text { ORDERED FROM CSU COPY CENTER ON } \\
\text { FEBRUARY 8, 1996. PHONE: } 1-970-491- \\
1828\end{array}$ \\
\hline IT Library & 0891.05 & $\begin{array}{l}\text { Nelson, P.H., R. Snyder, and J.E. Kibler. 1991. Abstract: } \\
\text { Fracture Counts from Borehole Logs, USGS Open-File Report } \\
91-125 .\end{array}$ & $\begin{array}{l}\text { Fractures in } \mathrm{H}-4 \text { counted using sonic } \\
\text { waveform, televiewer, and television tools. } \\
\text { Median dip angle reported }\end{array}$ \\
\hline IT Library & 1308 & $\begin{array}{l}\text { Newmark, R.L. and L. McKague. 1988. U20aw Site } \\
\text { Characteristics Report, CP 88-201. Lawrence Livermore } \\
\text { National Laboratory. }\end{array}$ & Fracture frequency reported \\
\hline IT Library & 1235 & $\begin{array}{l}\text { Newmark, R.L: and W.B. McKinnis. 1990. U20bf Site } \\
\text { Characteristics Report, CP 90-216. Lawrence Livermore } \\
\text { National Laboratory. }\end{array}$ & Fracture frequency reported \\
\hline IT Library & 1212 & $\begin{array}{l}\text { Newmark, R.L. and J.L. Wagoner. 1988. U19ax 615.7-m Site } \\
\text { Characteristics Report, CP 88-73. Lawrence Livermore } \\
\text { National Laboratory. }\end{array}$ & Location of cooling joints indicated \\
\hline IT Library & 4736 & $\begin{array}{l}\text { Newmark, R.L. and J.L. Wagoner. 1990. U20bb Site } \\
\text { Characteristics Report, CP 90-72. Lawrence Livermore } \\
\text { National Laboratory. }\end{array}$ & Fracture frequency reported \\
\hline
\end{tabular}


Table B-1

Annotated Bibliography of Nevada Test Site Fracture Data

(Page 11 of 19)

\begin{tabular}{|c|c|c|c|}
\hline Source & $\begin{array}{l}\text { Tracking } \\
\text { Number }\end{array}$ & Reference & Summary of Relevant Data \\
\hline IT Library & 0470 & $\begin{array}{l}\text { Niemi, A. and G.S. Bodvarsson. ·1988. "Preliminary Capillary } \\
\text { Hysteresis Simulations in Fractured Rocks, Yucca Mountain, } \\
\text { Nevada," In Journal of Contaminant Hydrology, Vol. } 3 . \\
\text { Amsterdam: Elsevier Science Publishers B.V. }\end{array}$ & $\begin{array}{l}\text { Affects of hysteretic capillary pressure - liquid } \\
\text { saturation on flow and liquid saturation in } \\
\text { fractured tuff simulated }\end{array}$ \\
\hline DOE/NV Library & LA-10859-MS & $\begin{array}{l}\text { Norris, A.E., F.M. Byers, Jr., and T.J. Merson. 1986. Fran } \\
\text { Ridge Horizontal Coring Summary Report, Hole UE-25h\#1, } \\
\text { Yucca Mountain Area, Nye County, Nevada, LA-10859-MS. } \\
\text { Los Alamos, NM: Los Alamos National Laboratory. }\end{array}$ & Fracture frequency and fillings reported \\
\hline IT Library & 0850.09 & $\begin{array}{l}\text { Novakowski, K.S. 1988. "Comparison of Fracture Aperture } \\
\text { Widths Determined from Hydraulic Measurements and Tracer } \\
\text { Experiments." Paper presented at the Fourth } \\
\text { Canadian/American Conference on Hydrogeology, Banff, } \\
\text { Alberta, Canada, June } 21-24 \text {, National Water Well . } \\
\text { Association, Dublin, Ohio. }\end{array}$ & $\begin{array}{l}\text { Fracture aperture widths calculated using } \\
\text { cubic law equation }\end{array}$ \\
\hline IT Library & 2445 & $\begin{array}{l}\text { Paillet, F. 1993. "Using Borehole Geophysics and Cross- } \\
\text { Borehole Flow Testing to Define Hydraulic Connections } \\
\text { Between Fracture Zones in Bedrock Aquifers." In Journal of } \\
\text { Applied Geophysics: Amsterdam: Elsevier Science } \\
\text { Publishers, B.V. }\end{array}$ & $\begin{array}{l}\text { Geophysical fracture logging techniques } \\
\text { discussed }\end{array}$ \\
\hline IT Library & 2451 & $\begin{array}{l}\text { Paillet, F. 1994. Application of Borehole Geophysics in the } \\
\text { Characterization of Flow in Fractured Rocks, USGS Water- } \\
\text { Resources Investigations Report } 93-4214 \text {. }\end{array}$ & $\begin{array}{l}\text { Geophysical fracture logging techniques } \\
\text { discussed }\end{array}$ \\
\hline IT Library & 1370 & $\begin{array}{l}\text { Pawloski, G.A. 1985. U20ak 608-m Preliminary Site } \\
\text { Characteristics Summany, CP 85-19. Lawrence Livermore } \\
\text { National Laboratory. }\end{array}$ & Location of cooling cracks indicated \\
\hline IT Library & 1307 & $\begin{array}{l}\text { Pawioski, G. 1987. U20ay 620.3-m Site Characteristic } \\
\text { Report, CP 87-63. Lawrence Livermore National Laboratory. }\end{array}$ & Fracture frequency reported \\
\hline
\end{tabular}




\section{Table B-1}

Annotated Bibliography of Nevada Test Site Fracture Data (Page 12 of 19)

\begin{tabular}{|c|c|c|c|}
\hline Source & $\begin{array}{l}\text { Tracking } \\
\text { Number }\end{array}$ & Reference & Summary of Relevant Data \\
\hline IT Library & 0460 & $\begin{array}{l}\text { Peters, R.R. and E.A. Klavetter. 1988. "A Continuum Model } \\
\text { for Water Movement in an Unsaturated Fractured Rock Mass." } \\
\text { In Water Resources Research, Vol. 24, No. 3: 416-430. }\end{array}$ & $\begin{array}{l}\text { Continuum model used to model flow in the } \\
\text { unsaturated zone at Yucca Mountain } \\
\text { presented }\end{array}$ \\
\hline IT Library & 0087 & $\begin{array}{l}\text { Peters, R.R., E.A. Klavetter, I.J. Hall, S.C. Blair, P.R. Heller, } \\
\text { and G.W. Gee. 1984. Fracture and Matrix Hydrologic } \\
\text { Characteristics of Tuffaceous Materials from Yucca Mountain, } \\
\text { Nye County, Nevada, SAND84-1471. }\end{array}$ & $\begin{array}{l}\text { Porosities and hydraulic conductivities for } 48 \\
\text { different locations at Yucca Mountain } \\
\text { reported. Aperture values derived using } \\
\text { cubic law equation }\end{array}$ \\
\hline IT Library & 4688 & $\begin{array}{l}\text { Rautman, C.A., L.E. Flint, A.L. Flint, and J.D. Istok. } 1995 . \\
\text { Physical and Hydrologic Properties of Outcrop Samples from a } \\
\text { Nonwelded to Welded Tuff Transition, Yucca Mountain, } \\
\text { Nevada, USGS Water-Resources Investigations Report 95- } \\
\text { 4061. }\end{array}$ & $\begin{array}{l}\text { Saturated hydraulic conductivity of Tiva } \\
\text { Canyon Tuff samples reported }\end{array}$ \\
\hline IT Library & 1454 & $\begin{array}{l}\text { Raytheon Services Nevada. 1993. Yucca Mountain Project, } \\
\text { Wet and Dry Drilling Project, Rock Core Properties, Porosity } \\
\text { Measurement Methods and Lithium Bromide Analyses, } \\
\text { Volume } 1 \text { of 3. Mercury, NV. }\end{array}$ & $\begin{array}{l}\text { Water contents, saturations, porosities, and } \\
\text { permeabilities for } 40 \text { core samples from the } \\
\text { G-Tunnel reported }\end{array}$ \\
\hline IT Library & 1456 & $\begin{array}{l}\text { Raytheon Services Nevada. 1993. Yucca Mountain Project, } \\
\text { Wet and Dry Drilling Project, Rock Core Properties and } \\
\text { Mercury Porosimetry, Volume } 3 \text { of 3. Mercury, NV. }\end{array}$ & $\begin{array}{l}\text { Rock moisture, density, and porosity data for } \\
40 \text { core samples from the G-Tunnel wet and } \\
\text { dry drilling program reported }\end{array}$ \\
\hline IT Library & 1137.307 & $\begin{array}{l}\text { Reimus, P.W., B.A. Robinson, and R.J. Glass. } 1983 . \\
\text { "Aperture Characteristics, Saturated Fluid-Flow, and Tracer- } \\
\text { Transport Calculations for a Natural Fracture, High Level } \\
\text { Radioactive Waste Management." Proceedings of the Fourth } \\
\text { Annual International Conference, April 26-30, Sponsored by } \\
\text { the University of Nevada, Las Vegas. }\end{array}$ & $\begin{array}{l}\text { Aperture distribution within a natural fracture } \\
\text { discussed }\end{array}$ \\
\hline IT Library & 4681 & $\begin{array}{l}\text { Roberts, J.J. and W. Lin. 1994. Permeability of Fractured Tuff } \\
\text { as Functions of Temperature and Confining Pressure, UCRL- } \\
\text { JC-119116. Lawrence Livermore National Laboratory. }\end{array}$ & $\begin{array}{l}\text { Permeability of Topopah Spring Tuff sample } \\
\text { with a single fracture measured }\end{array}$ \\
\hline
\end{tabular}




\section{Table B-1}

\section{Annotated Bibliography of Nevada Test Site Fracture Data}

(Page 13 of 19)

\begin{tabular}{|c|c|c|c|}
\hline Source & $\begin{array}{l}\text { Tracking } \\
\text { Number }\end{array}$ & Reference & Summary of Relevant Data \\
\hline IT Library · & 0175 & $\begin{array}{l}\text { Robison, J.H. and R.W. Craig. 1991. Geohydrology of Rocks } \\
\text { Penetrated by Test Well USWH-5, Yucca Mountain, Nye } \\
\text { County, Nevada, USGS Open-File Report 88-4168. }\end{array}$ & $\begin{array}{l}\text { Borehole flow survey and pump test results } \\
\text { reported. Finite-conductivity-vertical-fracture } \\
\text { model used to calculate fracture } \\
\text { conductivities }\end{array}$ \\
\hline IT Library & 0036 & $\begin{array}{l}\text { Rulon, J., G.S. Bodvarsson, and P. Montazer. } 1986 . \\
\text { Preliminary Numerical Simulations of Groundwater Flow in the } \\
\text { Unsaturated Zone, Yucca Mountain, Nevada, USGS Water- } \\
\text { Resources Investigations Report. }\end{array}$ & $\begin{array}{l}\text { Fracture density, porosity, permeability, and } \\
\text { saturated horizontal hydraulic conductivity } \\
\text { reported; Theoretical aperture widths } \\
\text { presented }\end{array}$ \\
\hline IT Library & 0827 & $\begin{array}{l}\text { Rush, F.E., W. Thordarson, and L. Bruckheimer. } 1983 . \\
\text { Geohydrologic and Drill-Hole Data for Test Well USW H-1, } \\
\text { Adjacent to Nevada Test Site, Nye County, Nevada, USGS } \\
\text { Open-File Report 83-141. }\end{array}$ & $\begin{array}{l}\text { Porosity, pore saturation, and pore-water } \\
\text { content reported for } 48 \text { core samples. } \\
\text { Horizontal and vertical matrix hydraulic } \\
\text { conductivities for saturated-zone samples } \\
\text { presented; Televiewer log summarized. } \\
\text { Borehole flow, pump test and injection test } \\
\text { results reported }\end{array}$ \\
\hline IT Library & 0016 & $\begin{array}{l}\text { Rush, F.E., W. Thordarson, and D.G. Pyles. } 1984 . \\
\text { Geohydrology of Test Well USWH-1, Yucca Mountain, Nye } \\
\text { County, Nevada, USGS Water-Resources Investigations } \\
\text { Report 84-4032. }\end{array}$ & $\begin{array}{l}\text { Matrix porosity, matrix hydraulic conductivity, } \\
\text { pore-water content, distribution of porous } \\
\text { rock based on geophysical logs, occurrence, } \\
\text { and orientation of lineations observed with } \\
\text { acoustic-televiewer log in water-filled portion } \\
\text { of hole, and aquifer test data reported }\end{array}$ \\
\hline IT Library & 0090 & $\begin{array}{l}\text { Russell, C.E. 1987. "Hydrogeologic Investigations of Flow in } \\
\text { Fractured Tuffs, Rainier Mesa, Nevada Test Site," Thesis, } \\
\text { Desert Research Institute, University of Nevada System, Las } \\
\text { Vegas, Nevada. }\end{array}$ & $\begin{array}{l}\text { Groundwater travel time through fractured tuff } \\
\text { reported for Rainier Mesa U12n Tunnel }\end{array}$ \\
\hline
\end{tabular}


Table B-1

Annotated Bibliography of Nevada Test Site Fracture Data

(Page 14 of 19)

\begin{tabular}{|c|c|c|c|}
\hline Source & $\begin{array}{l}\text { Tracking } \\
\text { Number }\end{array}$ & Reference & Summary of Relevant Data \\
\hline IT Library & 0310 & $\begin{array}{l}\text { Russell, C.E., J.W. Hess, and S.W. Tyler. } 1987 . \\
\text { Hydrogeologic Investigations of Flow in Fractured Tuffs, } \\
\text { Rainier Mesa, Nevada Test Site. American Geophysical } \\
\text { Union. }\end{array}$ & $\begin{array}{l}\text { Groundwater travel time through fractured tuff } \\
\text { reported for Rainier Mesa U12n Tunnel }\end{array}$ \\
\hline IT Library. & 4687 & $\begin{array}{l}\text { Schwartz, B.M. 1990. SNL Yucca Mountain Project Data } \\
\text { Report: Density and Porosity Data for Tuffs from the } \\
\text { Unsaturated Zone at Yucca Mountain, Nevada, SAND88- } \\
\text { 0811. Sandia National Laboratory. }\end{array}$ & Porosity values reported \\
\hline IT Library & 1184 & $\begin{array}{l}\text { Scott, R.B. and M. Castellanos. 1984. Stratigraphic and } \\
\text { Structural Relations of Volcanic Rocks in Drill Holes USW GU- } \\
3 \text { and USW G-3, Yucca Mountain, Nye County, Nevada, } \\
\text { USGS Open-File Report 84-491. }\end{array}$ & $\begin{array}{l}\text { Fracture frequency, orientation, and coatings } \\
\text { reported }\end{array}$ \\
\hline IT Library & 0781 & $\begin{array}{l}\text { Scott, R.B., R.W. Spengler, S. Diehl, A.R. Lappin, and M.P. } \\
\text { Chornack. } 1983 . \text { "Geologic Character of Tuffs in the } \\
\text { Unsaturated Zone at Yucca Mountain, Southern Nevada." In } \\
\text { Role of the Unsaturated Zone in Radioactive and Hazardous } \\
\text { Waste Disposal, pp. 289-335, J.W. Mercer, ed. Ann Arbor, MI: } \\
\text { Ann Arbor Science Publishers. }\end{array}$ & $\begin{array}{l}\text { Fracture frequency and orientation discussed; } \\
\text { Hydrologic conceptual model for Yucca } \\
\text { Mountain presented. }\end{array}$ \\
\hline IT Library & 0891.14 & $\begin{array}{l}\text { Smoot, J.L., 1991, Flow Through Variable Aperture Fractures, } \\
\text { USGS Open-File Report 91-125 [ABSTRACT]. }\end{array}$ & $\begin{array}{l}\text { Flow through a vertical fracture in the } \\
\text { Topopah Spring welded tuff modeled; } \\
\text { Assumed aperture values reported }\end{array}$ \\
\hline IT Library & 1162 & $\begin{array}{l}\text { Spengler, R.W. and M.P. Chornack. 1984. Stratigraphic and } \\
\text { Structural Characteristics of Volcanic Rocks in Core Hole } \\
\text { USW G-4, Yucca Mountain, Nye County, Nevada, USGS } \\
\text { Open-File Report 84-789. }\end{array}$ & $\begin{array}{l}\text { Detailed report of fracture frequency, } \\
\text { orientation, filling, and occurrence in } \\
\text { volcanics with varying degrees of welding }\end{array}$ \\
\hline
\end{tabular}


Table B-1

\section{Annotated Bibliography of Nevada Test Site Fracture Data}

(Page 15 of 19)

\begin{tabular}{|c|c|c|c|}
\hline Source & $\begin{array}{l}\text { Tracking } \\
\text { Number }\end{array}$ & Reference & Summary of Relevant Data \\
\hline IT Library & 0831 & $\begin{array}{l}\text { Spengler, R.W. and J.G. Rosenbaum. 1980. Preliminary } \\
\text { Interpretations of Geologic Results Obtained from Boreholes } \\
\text { UE25a-4, }-5,-6 \text {, and }-7 \text {, Yucca Mountain, Nevada Test Site, } \\
\text { USGS Open-File Report } 80-929 \text {. }\end{array}$ & $\begin{array}{l}\text { Fracture frequency and orientation plotted } \\
\text { and discussed }\end{array}$ \\
\hline IT Library & 4683 & $\begin{array}{l}\text { Spengler, R.W., F.M. Byers, Jr. and J.B. Warner. } 1981 . \\
\text { Stratigraphy and Structure of Volcanic Rocks in Drill Hole } \\
\text { USW-G1, Yucca Mountain, Nye County, Nevada, USGS } \\
\text { Open-File Report 81-1349. }\end{array}$ & $\begin{array}{l}\text { Fracture coatings, frequency, and orientation } \\
\text { identified }\end{array}$ \\
\hline IT Library & 1599 & $\begin{array}{l}\text { Spengler, R.W., D.C. Muller, and R.B. Livermore. Preliminary } \\
\text { Report on the Geology and Geophysics of Drill Hole UE25a-1, } \\
\text { Yucca Mountain, Nevada Test Site, USGS Open-File Report } \\
79-1244 \text {. }\end{array}$ & $\begin{array}{l}\text { Joint frequency, orientation and filling } \\
\text { minerals reported based on a continuous } \\
\text { core sample from } 0 \text { to } 2,500 \text { feet ( } 95.3 \\
\text { percent recovery) }\end{array}$ \\
\hline IT Library & 1137 & $\begin{array}{l}\text { Spengler, R.W., C.A. Braun, R.M. Linden, L.G. Martin, D.M. } \\
\text { Ross-Brown, and R.L. Blackburn. 1993. "Structural Character } \\
\text { of the Ghost Dance Fault, Yucca Mountain, Nevada, High } \\
\text { Level Radioactive Waste Management." Proceedings of the } \\
\text { Fourth Annual International Conference, Las Vegas, Nevada, } \\
\text { April 26-30, Volume I: } 653-659 \text {, hosted by the University of } \\
\text { Nevada, Las Vegas. }\end{array}$ & $\begin{array}{l}\text { Attributes of } 745 \text { fractures studied. Length, } \\
\text { strike, and dip summarized }\end{array}$ \\
\hline IT Library & 4690 & $\begin{array}{l}\text { Stock, J.M., J.H. Healy, and S.H. Hickman. 1984. Report on } \\
\text { Televiewer Log and Stress Measurements in Core Hole USW } \\
\text { G-2, Nevada Test Site, October-November 1982, USGS } \\
\text { Open-File Report 84-172. }\end{array}$ & $\begin{array}{l}\text { Fracture occurrence and orientation } \\
\text { discussed }\end{array}$ \\
\hline IT Library & 0872 & $\begin{array}{l}\text { Stock, J.M., J.H. Healy, J. Svitek, and L. Masten. } 1986 . \\
\text { Report on Televiewer Log and Stress Measurements in Holes } \\
\text { USW G-3 and UE-25p1, Yucca Mountain, Nye County, } \\
\text { Nevada, USGS Open-File Report 86-369. }\end{array}$ & $\begin{array}{l}\text { Fracture occurrence and orientation } \\
\text { discussed }\end{array}$ \\
\hline
\end{tabular}


Table B-1

Annotated Bịbliography of Nevada Test Site Fracture Data

(Page 16 of 19)

\begin{tabular}{|c|c|c|c|}
\hline Source & $\begin{array}{l}\text { Tracking } \\
\text { Number }\end{array}$ & Reference & Summary of Relevant Data \\
\hline IT Library & 0009 & $\begin{array}{l}\text { Thordarson, W. 1983. Geohydrologic Data and Test Results } \\
\text { from Well J-13, Nevada Test Site, Nye County, Nevada, } \\
\text { USGS Water-Resources Investigations Report 83-4171. }\end{array}$ & $\begin{array}{l}\text { Porosities, hydraulic conductivities, and } \\
\text { aquifer test results reported }\end{array}$ \\
\hline IT Library & 0017 & $\begin{array}{l}\text { Thordarson, W. F.E. Rush, and S.J. Waddell. } 1985 . \\
\text { Geohydrology of Test Well USW H-3, Yucca Mountain, Nye } \\
\text { County, Nevada, USGS Water-Resources Investigations } \\
\text { Report 84-4272. }\end{array}$ & $\begin{array}{l}\text { Distribution of porous rock based on } \\
\text { geophysical logs, borehole-flow survey, and } \\
\text { pump test results reported }\end{array}$ \\
\hline IT Library & 0172 & $\begin{array}{l}\text { Thordarson, W., F.E. Rush, R.W: Spengler, and S.J. Waddell. } \\
\text { 1984. Geohydrologic and Drill-Hole Data for Test Well USW } \\
\text { H-3, Yucca Mountain, Nye County, Nevada, USGS Open-File } \\
\text { Report 84-149. }\end{array}$ & $\begin{array}{l}\text { Fracture frequency versus depth qualitatively } \\
\text { described based on televiewer log }\end{array}$ \\
\hline IT Library & 4691 & $\begin{array}{l}\text { Throckmorton, C.K. U.S. Geological Survey and U.S. } \\
\text { Department of Energy. } 1987 \text {. Photogeologic Study of Small- } \\
\text { Scale Linear Features Near a Potential Nuclear-Waste } \\
\text { Repository Site at Yucca Mountain, Southem Nye County, } \\
\text { Nevada, USGS Open-File Report 87-409. }\end{array}$ & $\begin{array}{l}\text { Fracture traces recorded on photogeologic } \\
\text { map compared with field fracture patterns }\end{array}$ \\
\hline IT Library & 1137 & $\begin{array}{l}\text { Tsang, Y.W., K. Pruess, and J.S.Y. Wang. 1993. "The Role } \\
\text { of Fault Zone in Affecting Multiphase Flow at Yucca Mountain, } \\
\text { High Level Radioactive Waste." Proceedings of the Fourth } \\
\text { Annual Confererice, Las Vegas, Nevada, April 26-30, Volume } \\
\text { l: } 660-666 \text {, hosted by the University of Nevada, Las Vegas. }\end{array}$ & $\begin{array}{l}\text { Fracture permeabilities used in model } \\
\text { reported }\end{array}$ \\
\hline IT Library & 0435 & $\begin{array}{l}\text { Tsang, Y.W. and P.A. Witherspoon. 1985. "Effects of } \\
\text { Fracture Roughness on Fluid Flow Through a Single } \\
\text { Deformable Fracture, International Association of } \\
\text { Hydrogeologists Memoirs." In Volume XVII, Part } 2 \\
\text { Proceedings, Hydrogeology of Rocks of LoW Permeability. }\end{array}$ & $\begin{array}{l}\text { Effects of fracture surface roughness on fluid } \\
\text { flow through a single deformable fracture. } \\
\text { discussed }\end{array}$ \\
\hline
\end{tabular}


Table B-1

Annotated Bibliography of Nevada Test Site Fracture Data

(Page 17 of 19)

\begin{tabular}{|c|c|c|c|}
\hline Source & $\begin{array}{l}\text { Tracking } \\
\text { Number }\end{array}$ & Reference & Summary of Relevant Data \\
\hline IT Library & 0891.02 & $\begin{array}{l}\text { Verbeek, E.R. and M.A. Grout, 1991, Some General } \\
\text { Properties of Joints and Joint Networks in Horizontally } \\
\text { Layered Sedimentary and Volcanic Rocks -- An Overview, } \\
\text { USGS Open-File Report 91-125 [ABSTRACT]. }\end{array}$ & Joint properties discussed \\
\hline IT Library & 0031 & $\begin{array}{l}\text { Waddell, R.K., J.H. Robison, and R.K. Blankennagel. } 1984 . \\
\text { Hydrology of Yucca Mountain and Vicinity, Nevada-California - } \\
\text { - Investigative Results through Mid-1983, USGS Water- } \\
\text { Resources Investigations Reports 84-4267. }\end{array}$ & $\begin{array}{l}\text { Matrix hydraulic conductivities, fracture } \\
\text { porosity, and pump test data reported }\end{array}$ \\
\hline IT Library & 1369 & $\begin{array}{l}\text { Wagoner, J.L. 1985. U20ai 609-m Preliminary Site } \\
\text { Characteristics Summary, CP 85-86. Lawrence Livermore } \\
\text { National Laboratory. }\end{array}$ & Location of cooling joints indicated \\
\hline IT Library & 1311 & $\begin{array}{l}\text { Wagoner, J. and S. Clark. 1986. U20as 605-m Site } \\
\text { Characteristics Report, CP 86-32. Lawrence Livermore } \\
\text { National Laboratory. }\end{array}$ & Location of cooling joints indicated \\
\hline DOE/NV Library & LBL-18473 & $\begin{array}{l}\text { Wang, J.S.Y. and T.N. Narasimhan. Lawrence Berkeley } \\
\text { Laboratory. 1984. Hydrologic Mechanisms Governing Fluid } \\
\text { Flow in Partially Saturated, Fractured, Porous Tuff at Yucca } \\
\text { Mountain, LBL-18473, UC-70. Lawrence Berkeley Laboratory, } \\
\text { Earth Sciences. }\end{array}$ & $\begin{array}{l}\text { Fracture spacing and orientation from core } \\
\text { analyses presented }\end{array}$ \\
\hline IT Library & 0109 & $\begin{array}{l}\text { Wang, J.S.Y. and T.N. Narasimhan. Lawrence Berkeley } \\
\text { Laboratory. 1985. Hydrologic Mechanisms Governing Fluid } \\
\text { Flow in Partially Saturated, Fractured, Porous Tuff at Yucca } \\
\text { Mountain, SAND84-7202. Prepared for Sandia National } \\
\text { Laboratory. }\end{array}$ & $\begin{array}{l}\text { Fracture frequency, inclination, permeability, } \\
\text { and saturated conductivity reported }\end{array}$ \\
\hline
\end{tabular}


Table B-1

Annotated Bibliography of Nevada Test Site Fracture Data

(Page 18 of 19)

\begin{tabular}{|c|c|c|c|}
\hline Source & $\begin{array}{l}\text { Tracking } \\
\text { Number }\end{array}$ & Reference & Summary of Relevant Data \\
\hline IT Library & 4680 & $\begin{array}{l}\text { Wang, J.S.Y. and T.N. Narasimhan. Lawrence Berkeley } \\
\text { Laboratory. 1986. Hydrologic Mechanisms Governing } \\
\text { Partially Saturated Fluid Flow in Fractured Welded Units and } \\
\text { Porous Non-Welded Units at Yucca Mountain, SAND85-7114. } \\
\text { Sandia National Laboratory. }\end{array}$ & $\begin{array}{l}\text { Fracture frequency, orientation, and } \\
\text { calculated values for fracture permeability } \\
\text { and aperture for } 5 \text { unsaturated tuff samples } \\
\text { from USW G-4 presented and used in a flow } \\
\text { model }\end{array}$ \\
\hline DOE/NV Library & SAND87-7070 & $\begin{array}{l}\text { Wang, J.S. Y. and T.N. Narasimhan. Lawrence Berkeley } \\
\text { Laboratory. 1988. Hydrologic Modeling of Vertical and Lateral } \\
\text { Movement of Partially Saturated Fluid Flow Near a Fault Zone } \\
\text { at Yucca Mountain, SAND87-7070; Unlimited Release, UC-70. } \\
\text { Prepared for Sandia National Laboratory. }\end{array}$ & $\begin{array}{l}\text { Tuff matrix and fracture data compared with } \\
\text { model parameters; Correlations between } \\
\text { saturated conductivity and unsaturated } \\
\text { parameters for tuff matrix, fractures, and } \\
\text { faults reported }\end{array}$ \\
\hline IT Library & 0171 & $\begin{array}{l}\text { Weeks, E.P. and W.E. Wilson. 1984. Preliminary Evaluation } \\
\text { of Hydrologic Properties of Cores of Unsaturated Tuff, Test } \\
\text { Well USW H-1, Yucca Mountain, Nevada, USGS Water- } \\
\text { Resources Investigations Report 84-4193. }\end{array}$ & $\begin{array}{l}\text { Moisture characteristics curves relating } \\
\text { saturation and moisture tension developed }\end{array}$ \\
\hline IT Library & 0108 & $\begin{array}{l}\text { Whitfield, M.S., E.P. Eshom, W. Thordarson, and D.H. } \\
\text { Schaefer. 1985. Geohydrology of Rocks Penetrated by Test } \\
\text { Well USW H-4, Yucca Mountain, Nye County, Nevada, USGS } \\
\text { Water-Resources Investigations Report 85-4030. }\end{array}$ & $\begin{array}{l}\text { Borehole flow survey and pump test results } \\
\text { reported }\end{array}$ \\
\hline IT Library & 0178 & $\begin{array}{l}\text { Whitfield, M.S., W. Thordarson, and E.P. Eshom. } 1984 . \\
\text { Geohydrologic and Drill-Hole Data for Test Well USW H-4, } \\
\text { Yucca Mountain, Nye County, Nevada, USGS Open-File } \\
\text { Report 84-449. }\end{array}$ & Pump test results reported \\
\hline IT Library & 0173 & $\begin{array}{l}\text { Whitfield, W.S., W. Thordarson, and D.P. Hammermeister. } \\
\text { 1990. Drilling Geohydrologic Data for Test Hole USW UZ-1, } \\
\text { Yucca Mountain, Nye County, Nevada, USGS Open-File } \\
\text { Report 90-354. }\end{array}$ & $\begin{array}{l}\text { Fracture distribution and orientation } \\
\text { presented based on four television } \\
\text { videotapes }\end{array}$ \\
\hline
\end{tabular}


Table B-1

Annotated Bibliography of Nevada Test Site Fracture Data

(Page 19 of 19)

\begin{tabular}{|c|c|c|c|}
\hline Source & $\begin{array}{l}\text { Tracking } \\
\text { Number }\end{array}$ & Reference & Summary of Relevant Data \\
\hline IT Library & 1137 & $\begin{array}{l}\text { Wittwer, C.S., G. Chen, and G.S. Bodvarsson. 1993. "Studies } \\
\text { of the Role of Fault Zones on Fluid Flow Using the Site-Scale } \\
\text { Numerical Model of Yucca Mountain, High Level Radioactive } \\
\text { Waste Management." .Proceedings of the Fourth Annual. } \\
\text { Conference, Las Vegas, Nevada, April 26-30, 1993, Volume I: } \\
667-674 \text {, hosted by the University of Nevada, Las Vegas. }\end{array}$ & $\begin{array}{l}\text { Combined fracture and matrix characteristic } \\
\text { curves for welded tuffs presented showing } \\
\text { saturated permeability versus capillary } \\
\text { pressure. }\end{array}$ \\
\hline YMP Library & SAND86-1015 & $\begin{array}{l}\text { Zimmerman, R.M. and R.E. Finley. 1987. Summary of } \\
\text { Geomechanical Measurements Taken In and Around the G- } \\
\text { Tunnel Underground Facility, NTS, Sandia National } \\
\text { Laboratory, SAND86-1015, Unlimited Release, UC-70. }\end{array}$ & $\begin{array}{l}\text { Fracture permeabilities and aperture widths } \\
\text { presented }\end{array}$ \\
\hline YMP Library & SAND81-1971 & $\begin{array}{l}\text { Zimmerman, R.M. and W.C. Vollendorf. 1982. Geotechnical } \\
\text { Field Measurements, G-Tunnel, Nevada Test Site, SAND81- } \\
\text { 1971, Unlimited Release, UC-70. }\end{array}$ & Fracture permeabilities reported \\
\hline
\end{tabular}


Appendix C
Drill Hole Data 


\section{Location Data:}

Coordinates: $\quad$ Central Nevada State Planar: N 904,108 feet (ft) E 586,810 ft

Universal Transverse Mercator: $\quad$ N 4,120,739.0 meters (m) E $555,962.4 \mathrm{~m}$

Ground elevation: $\quad 2,065.3 \mathrm{~m}(6,776 \mathrm{ft})$

Static water level: $\quad 674.8 \mathrm{~m}(2.214 \mathrm{ft})$ depth

\section{Drilling Data:}

Spud date:

Total depth (TD):

Drilling technique(s):

\section{9/28/77}

$762.9 \mathrm{~m}(2,503 \mathrm{ft})$

This hole was continuously cored from $4.6 \mathrm{~m}$ (15 ft) to total depth using mud.

\section{Coring Data:}

Number of cores:

Total core recovered:

Percent of hole cored:

Cored interval(s):

Core size:
278 continuous core runs

Approximately $743 \mathrm{~m}(2,438 \mathrm{ft})(\sim 98 \%)$

$99.4 \%$

$4.6 \mathrm{~m}(15 \mathrm{ft})$ to total depth (TD)

6.03-centimeters (cm) ( $2 \%$-inch [in.]) diameter 
Table C-2

Condensed Stratigraphic and Lithologic Log for Exploratory Hole UE-19x (Page 1 of 2)

\begin{tabular}{|c|c|c|c|c|c|c|}
\hline \multicolumn{2}{|c|}{ Depth } & \multirow{2}{*}{ Stratigraphic Unit } & \multirow{2}{*}{ Lithology } & \multirow{2}{*}{$\begin{array}{c}\text { Stratigraphic } \\
\text { Symbol }\end{array}$} & \multicolumn{2}{|c|}{ Thickness } \\
\hline Meters & Feet & & & & Meters & Feet \\
\hline $0.0-5.3$ & $0-17.5$ & $\begin{array}{l}\text { Rhyolite of Beatty Wash, Volcanics of - } \\
\text { Fortymile Canyon }\end{array}$ & Nonwelded tuff, vitric & Tfbw & 5.3 & 17.5 \\
\hline $5.3-29.3$ & $17.5-96$ & $\begin{array}{l}\text { Mafic-rich, Ammonia Tanks Tuff, } \\
\text { Timber Mountain Group }\end{array}$ & $\begin{array}{l}\text { Moderately to densely welded ash-flow } \\
\text { tuff, vitric, bedded tuff upper portion }\end{array}$ & Tmar & 24.0 & 78.5 \\
\hline $29.3-56.3$ & $96-185$ & $\begin{array}{l}\text { Mafic-poor, Ammonia Tanks Tuff, } \\
\text { Timber Mountain Group }\end{array}$ & $\begin{array}{l}\text { Partially to moderately welded ash-flow } \\
\text { tuff, vitric to devitrified }\end{array}$ & Tmap & 27.0 & 89 \\
\hline $56.3-68.9$ & $185-226$ & $\begin{array}{l}\text { Bedded, Ammonia Tanks Tuff, Timber } \\
\text { Mountain Group }\end{array}$ & Bedded tuff, vitric & Tmab & 12.6 & 41.3 \\
\hline $68.9-73.4$ & $226-241$ & $\begin{array}{l}\text { Bedded, Rainier Mesa Tuff, Timber } \\
\text { Mountain Group }\end{array}$ & Bedded tuff, vitric & Tmrb & 4.5 & 14.8 \\
\hline $73.4-115.2$ & $241-378$ & $\begin{array}{l}\text { Mafic-rich, Rainier Mesa Tuff, Timber } \\
\text { Mountain Group }\end{array}$ & $\begin{array}{l}\text { Nonwelded to densely welded ash-flow } \\
\text { tuff, devitrified }\end{array}$ & Tmrr & 41.8 & 137.1 \\
\hline $115.2-291.8$ & $378-957$ & $\begin{array}{l}\text { Mafic-poor, Rainier Mesa Tuff, Timber } \\
\text { Mountain Group }\end{array}$ & $\begin{array}{l}\text { Partially to moderately welded ash-flow } \\
\text { tuff, generally devitrified }\end{array}$ & Tmrp & 176.6 & 579.4 \\
\hline $291.8-291.9$ & $957-958$ & $\begin{array}{l}\text { Andesite tephra, Rainier Mesa Tuff, } \\
\text { Timber Mountain Group }\end{array}$ & Bedded tuff, vitric & Tmra & 0.1 & 1 \\
\hline $291.9-299.4$ & $958-982$ & $\begin{array}{l}\text { Tuff of Holmes Road, Timber Mountain } \\
\text { Group }\end{array}$ & Bedded tuff, vitric & Tmrh & 7.5 & 24.6 \\
\hline $299.4-326.3$ & $982-1,071$ & $\begin{array}{l}\text { Pahute Mesa lobe, Tiva Canyon Tuff, } \\
\text { Paintbrush Group }\end{array}$ & $\begin{array}{l}\text { Nonwelded to densely welded ash-flow } \\
\text { tuff, vitric to devitrified }\end{array}$ & Tpcm & 26.9 & 88.3 \\
\hline $326.3-344.0$ & $1,071-1,129$ & $\begin{array}{l}\text { Rhyolite of Delirium Canyon, } \\
\text { Paintbrush Group }\end{array}$ & Bedded tuff & Tpd & 17.7 & 58 \\
\hline
\end{tabular}


Table C-2

Condensed Stratigraphic and Lithologic Log for Exploratory Hole UE-19x

(Page 2 of 2)

\begin{tabular}{|c|c|c|c|c|c|c|}
\hline \multicolumn{2}{|c|}{ Depth } & \multirow{2}{*}{ Stratigraphic Unit } & \multirow{2}{*}{ Lithology } & \multirow{2}{*}{$\begin{array}{c}\text { Stratigraphic } \\
\text { Symbol }\end{array}$} & \multicolumn{2}{|c|}{ Thickness } \\
\hline Meters & Feet & & & & Meters & Feet \\
\hline $344.0-579.9$ & $1,129-1,903$ & $\begin{array}{l}\text { Rhyolite of Echo Peak, Paintbrush } \\
\text { Group }\end{array}$ & $\begin{array}{l}\text { Rhyolite lava flow (upper portion), and } \\
\text { nonwelded to densely welded ash-flow } \\
\text { tuff, generally devitrified with vitric } \\
\text { upper part and zeolitized lower portion }\end{array}$ & Tpe & 545.9 & $1,791.1$ \\
\hline $579.9-687.5$ & $1,903-2,256$ & $\begin{array}{l}\text { Rhyolite of Silent Canyon, Paintbrush } \\
\text { Group }\end{array}$ & $\begin{array}{l}\text { Mostly rhyolite lava flow, minor flow } \\
\text { breccia and nonwelded tuff; denser } \\
\text { lava portion is vitric, while top and } \\
\text { bottom of interval are zeolitized }\end{array}$ & Tpr & 107.6 & 353.0 \\
\hline $687.5-696.1$ & $2,256-2,284$ & $\begin{array}{l}\text { Bedded Topopah Spring Tuff, } \\
\text { Paintbrush Group }\end{array}$ & Bedded tuff, zeolitized & Tptb. & 8.6 & 28.2 \\
\hline $696.1-758.4$ & $2,284-2,488$ & $\begin{array}{l}\text { Mafic-poor, Calico Hills Formation, } \\
\text { Volcanics of Area } 20\end{array}$ & Bedded tuff, zeolitized & Tacp & 62.3 & 204.4 \\
\hline $\begin{array}{c}758.4-762.9 \\
\text { TD }\end{array}$ & $\begin{array}{c}2,488-2,503 \\
\text { TD }\end{array}$ & Rhyolite of Inlet, Volcanics of Area 20 & Nonwelded tuff, zeolitized & Tai & 4.5 & 14.8 \\
\hline
\end{tabular}

Source: Ferguson, et al., 1994. 
Table C-3

Abridged Drill Hole Statistics for Exploratory Hole UE-18t

\section{Location Data:}

Coordinates: $\quad$ Central Nevada State Planar: N 865,793 ft

E 598,394 ft

Universal Transverse Mercator: $\quad$ N 4,109,094.59 m

$E 559,591.08 \mathrm{~m}$

Ground elevation: $\quad$. $\quad 1,585.3 \mathrm{~m}(5,201 \mathrm{ft})$

Static water level: . $\quad 278.9 \mathrm{~m}(915 \mathrm{ft})$

Drilling Data:

Spud date:

Total depth:

Drilling technique(s):

\section{$07 / 23 / 78$}

$792.5 \mathrm{~m}(2,600 \mathrm{ft})$

A 66-cm (26-in.) hole was drilled to $36.6 \mathrm{~m}$ (120.1 ft). The hole was continuously cored from $36.6 \mathrm{~m}$ $(120 \mathrm{ft})$ to its total depth of $792.5 \mathrm{~m}(2,600 \mathrm{ft})$ using bentonite mud with a liquid polymer as a lubricant. Lost circulation material was utilized as needed. Completed with a string of $6.03-\mathrm{cm}(2 \%-\mathrm{in}$.) diameter tubing set at $57.7 .9 \mathrm{~m}(1,896 \mathrm{ft})$.

\section{Coring Data:}

Number of cores:

Total core recovered:

Percent of hole cored:

Cored interval(s):

Core size:
278 continuous core runs

$733.2 \mathrm{~m}(2,405.6 \mathrm{ft}) ; 97 \%$ recovery

$95.4 \%$

$36.6-792.5 m(120-2,600 f t)$

HQ (2 \%-in. diameter) and

NQ (17/8-in. diameter) 
Table $\mathrm{C}-4$

Condensed Stratigraphic and Lithologic Log for Exploratory Hole UE-18t

\begin{tabular}{|c|c|c|c|c|c|c|}
\hline \multicolumn{2}{|c|}{ Depth } & \multirow{2}{*}{ Stratigraphic Unit } & \multirow{2}{*}{ Lithology } & \multirow{2}{*}{$\begin{array}{l}\text { Stratigraphic } \\
\text { Symbol }\end{array}$} & \multicolumn{2}{|c|}{ Thickness } \\
\hline Meters & Feet & & & & Meters & Feet \\
\hline $0.0-91.7$ & $0-301$ & Alluvium & Tuffaceous alluvium & QTa & 91.7 & 301 \\
\hline $91.7-108.1$ & $301-355$ & $\begin{array}{l}\text { Trail Ridge Tuff, } \\
\text { Thirsty Canyon Group }\end{array}$ & $\begin{array}{l}\text { Mostly moderately welded ash-flow tuff } \\
\text { with bedded tuff at base }\end{array}$ & $\mathrm{THt}$ & 16.4 & 53.8 \\
\hline $108.1-131.9$ & $355-433$ & $\begin{array}{l}\text { Pahute Mesa Tuff, } \\
\text { Thirsty Canyon Group }\end{array}$ & $\begin{array}{l}\text { Nonwelded to moderately welded ash- } \\
\text { flow tuff }\end{array}$ & Ttp & 23.8 & 78.1 \\
\hline $131.9-258.5$ & $433-848$ & $\begin{array}{l}\text { Rhyolite of Chukar Canyon, Volcanics } \\
\text { of Fortymile Canyon }\end{array}$ & Bedded tuff & Tfbr & 126.6 & 415.4 \\
\hline $258.5-286.1$ & $848-.939$ & $\begin{array}{l}\text { Rhyolite of Beatty Wash, } \\
\text { Volcanics of Fortymile Canyon }\end{array}$ & Bedded tuff & Tfbw & 27.6 & 90.6 \\
\hline $286.1-288.0$ & $939-945$ & $\begin{array}{l}\text { Tuff of Crooked Canyon, Timber } \\
\text { Mountain Group }\end{array}$ & Bedded tuff & Tmac & 1.9 & 6.2 \\
\hline $288.0-353.6$ & $945-1,160$ & $\begin{array}{l}\text { Mafic-rich, Ammonia Tanks Tuff, } \\
\text { Timber Mountain Group }\end{array}$ & $\begin{array}{l}\text { Partially welded to densely welded ash- } \\
\text { flow tuff }\end{array}$ & Tmar & 65.6 & 215.2 \\
\hline $353.6-396.9$ & $1,160-1,302$ & $\begin{array}{l}\text { Mafic-poor, Ammonia Tanks Tuff, } \\
\text { Timber Mountain Group }\end{array}$ & $\begin{array}{l}\text { Nonwelded to densely welded ash-flow } \\
\text { tuff }\end{array}$ & Tmap & 43.3 & 142.1 \\
\hline $396.9-440.7$ & $1,302-1,446$ & $\begin{array}{l}\text { Bedded, Ammonia Tanks Tuff, Timber. } \\
\text { Mountain Group }\end{array}$ & Bedded tuff & Tmab & 43.8 & 143.7 \\
\hline $4.40 .7-498.4$ & $1,446-1,635$ & $\begin{array}{l}\text { Bedded, Rainier Mesa Tuff, Timber } \\
\text { Mountain Tuff }\end{array}$ & Bedded tuff & Tmrb & 57.7 & 189.3 \\
\hline $\begin{array}{c}498.4-792.5 \\
\text { (TD) }\end{array}$ & $\begin{array}{c}1,635-2,600 \\
\text { (TD) }\end{array}$ & $\begin{array}{l}\text { Mafic-rich, Rainier Mesa Tuff, Timber } \\
\text { Mountain Group }\end{array}$ & Moderately welded ash-flow tuff & Tmrr & 294.1 & 964.9 \\
\hline
\end{tabular}

Source: Ferguson, et al., 1994. 


\title{
Table C-5
}

\section{Abridged Drill Hole Statistics for Exploratory Hole UE-18r}

\section{Location Data:}

Coordinates:

\author{
Central Nevada State Planar: \\ Universal Transverse Mercator: \\ Ground Elevation: \\ Static Water Level:
}

N $868,100 \mathrm{ft}$

E 564,700 ft

$\mathrm{N} 4,109,761.51 \mathrm{~m}$

E $549,321.53 \mathrm{~m}$

$1,688 \mathrm{~m}(5,538 \mathrm{ft})$

$416.1 \mathrm{~m}(1,365 \mathrm{ft})$

depth on $05 / 18 / 93$

\section{Drilling Data:}

Spud date:

Total depth:

Drilling techniques:
$11 / 29 / 67$

$1,525.2 \mathrm{~m}(5,004 \mathrm{ft})$

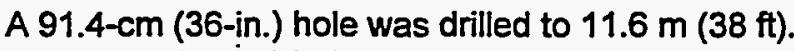

A $38.1-\mathrm{cm}$ (15-in.) hole was drilled to $498.7 \mathrm{~m}$

$(1,636 \mathrm{ft})$ using direct circulation air/foam. $A$ 25.1-cm

$(97 / 8$-in.) hole was drilled to $1,520.3 \mathrm{~m}(4,988 \mathrm{ft})$ also using direct circulation air/foam with no apparent drilling problems. A $15.6-\mathrm{cm}(61 /-$-in.) hole was cored using a conventional diamond core bit to a total depth of $1,525.2 \mathrm{~m}(5,004 \mathrm{ft})$. A total of fifteen cores were taken at various depths during drilling.

\section{Coring Data:}

Number of cores:

Total core recovered:

Percent of hole cored:

Cored interval(s):

Core size:
15 intermittent core runs

$35.7 \mathrm{~m}$ (117 ft); $97 \%$ recovery

$2.4 \%$

$154.8-1,525.2 \mathrm{~m}(508-5,004 \mathrm{ft})$

See Table C- 6 for additional coring information.

8.9-cm (3.5-in.) diameter 
Table C-6

Coring Data for Exploratory Hole UE-18r

\begin{tabular}{|c|c|c|c|c|c|}
\hline Core Run No. & $\begin{array}{c}\text { Depth Interval } \\
\text { (feet) }\end{array}$ & $\begin{array}{c}\text { Recovery } \\
\text { (feet) }\end{array}$ & $\begin{array}{l}\text { Stratigraphic } \\
\text { Unit }^{P}\end{array}$ & Lithology 2 & $\begin{array}{c}\text { Hydrostratigraphic } \\
\text { Unit }^{3}\end{array}$ \\
\hline $\begin{array}{l}\# 1 \\
\# 2 \\
\# 3\end{array}$ & $\begin{array}{c}508-516 \\
839-847 \\
1,148-1,156\end{array}$ & $\begin{array}{l}8 \\
8 \\
8 \\
\end{array}$ & $\begin{array}{l}\text { Tfbw } \\
\text { Tfbw } \\
\text { Tmac }\end{array}$ & $\begin{array}{l}\text { Lava } \\
\text { Lava } \\
\text { Tuff, PW }\end{array}$ & $\begin{array}{l}\text { TMA } \\
\text { TMA } \\
\text { TMA } \\
\end{array}$ \\
\hline $\begin{array}{l}\# 4 \\
\# 5 \\
\# 6 \\
\end{array}$ & $\begin{array}{l}1,366-1,373 \\
1,615-1,622 \\
1,922-1,931 \\
\end{array}$ & $\begin{array}{l}6 \\
6 \\
9 \\
\end{array}$ & $\begin{array}{l}\text { Tmac } \\
\text { Tmac } \\
\text { Tmacp }\end{array}$ & $\begin{array}{l}\text { Tuff, PW } \\
\text { Tuff, PW } \\
\text { Tuff, PW } \\
\end{array}$ & $\begin{array}{l}\text { TMA } \\
\text { TMA } \\
\text { TMA } \\
\end{array}$ \\
\hline $\begin{array}{l}\# 7 \\
\# 8 \\
\# 9 \\
\end{array}$ & $\begin{array}{l}2,228-2,234 \\
2,811-2,815 \\
3,096-3,106\end{array}$ & $\begin{array}{c}6 \\
4 \\
10 \\
\end{array}$ & $\begin{array}{c}\text { Tmacp } \\
\text { Tmr } \\
\text { Tmr } \\
\end{array}$ & $\begin{array}{l}\text { Tuff, MW } \\
\text { Tuff, DW } \\
\text { Tuff, NW }\end{array}$ & $\begin{array}{l}\text { TMA } \\
\text { TMA } \\
\text { TMA } \\
\end{array}$ \\
\hline $\begin{array}{l}\# 10 \\
\# 11 \\
\# 12 \\
\end{array}$ & $\begin{array}{l}3,604-3,610 \\
3,899-3,907 \\
4,212-4,217 \\
\end{array}$ & $\begin{array}{l}6 \\
8 \\
4 \\
\end{array}$ & $\begin{array}{l}\text { Tmat } \\
\text { Tmrb } \\
\text { Tmrb } \\
\end{array}$ & $\begin{array}{c}\text { Lava } \\
\text { Tuff Breccia } \\
\text { Tuff Breccia } \\
\end{array}$ & $\begin{array}{l}\text { TMA } \\
\text { TMA } \\
\text { TMA } \\
\end{array}$ \\
\hline $\begin{array}{l}\# 13 \\
\# 14 \\
\# 15 \\
\end{array}$ & $\begin{array}{l}4,594-4,600 \\
4,867-4,879 \\
4,988-5,004 \\
\end{array}$ & $\begin{array}{c}6 \\
12 \\
16 \\
\end{array}$ & $\begin{array}{l}\text { Tmrb } \\
\text { Tmrx } \\
\text { Tmrx } \\
\end{array}$ & $\begin{array}{l}\text { Tuff Breccia } \\
\text { Tuff Breccia } \\
\text { Tuff Breccia } \\
\end{array}$ & $\begin{array}{l}\text { TMA } \\
\text { TMA } \\
\text { TMA } \\
\end{array}$ \\
\hline
\end{tabular}

1 Refer to Table C-22 for explanation of stratigraphic nomenclature.

2 Refer to Table C-23 for explanation of lithologic nomenclature.

3 Refer toTable 1-4 for explanation of hydrostratigraphic nomenclature.

Total corè recovered: $35.7 \mathrm{~m}$ (117 ft); $97.5 \%$ recovery.

Amount of core logged for this fracture study: All core recovered $(35.7 \mathrm{~m})$, minus core samples removed (approximately $10 \%)$ for previous unrelated studies.

Static water level at $416.1 \mathrm{~m}(1,365 \mathrm{ft})$ on $11 / 18 / 93$ 
Table C-7

Condensed Stratigraphic and Lithologic Log for Exploratory Hole UE-18r

\begin{tabular}{|c|c|c|c|c|c|c|}
\hline \multicolumn{2}{|c|}{ Depth } & \multirow{2}{*}{ Stratigraphic Unit } & \multirow{2}{*}{ Lithology } & \multirow{2}{*}{$\begin{array}{l}\text { Stratigraphic } \\
\text { Symbol }\end{array}$} & \multicolumn{2}{|c|}{ Thickness } \\
\hline Metẹ & Feet & & & & Meter & Feet \\
\hline $0.0-17.1$ & $0-56$ & $\begin{array}{l}\text { Trail Ridge Tuff, } \\
\text { Thirsty Canyon Group }\end{array}$ & $\begin{array}{l}\text { Moderately welded ash-flow tuff with } 3 \\
\mathrm{~m} \text { bedded tuff at base, generally vitric }\end{array}$ & $\mathrm{Ttt}$ & 17.1 & 56 \\
\hline $17.1-39.0$ & $56-128$ & $\begin{array}{l}\text { Crystal-rich, Pahute Mesa Tuff, } \\
\text { Thirsty Canyon Group }\end{array}$ & Moderately welded ash-flow tuff & Ttpr & 21.9 & 71.9 \\
\hline $39.0-65.2$ & $128-214$ & $\begin{array}{l}\text { Crystal-poor, Pahute Mesa Tuff, } \\
\text { Thirsty Canyon Group }\end{array}$ & $\begin{array}{l}\text { Nonwelded to densely welded ash-flow } \\
\text { tuff }\end{array}$ & Ttpp & 26.2 & 86.0 \\
\hline $65.2-103.0$ & $214-338$ & $\begin{array}{l}\text { Rocket Wash Tuff, Thirsty Canyon } \\
\text { Group }\end{array}$ & Nonwelded ash-flow tuff & Ttr & 37.8 & 124.0 \\
\hline $103.0-324.6$ & $338-1,065$ & $\begin{array}{l}\text { Rhyolite of Beatty Wash, Volcanics } \\
\text { of Fortymile Canyon }\end{array}$ & $\begin{array}{l}\text { Rhyolite lava flow, pumiceous top and } \\
\text { flow breccia at base }\end{array}$ & Tfbw & 221.6 & 727.0 \\
\hline $324.6-1083.3$ & $1,065-3,554$ & $\begin{array}{l}\text { Ammonia Tanks Tuff, Timber } \\
\text { Mountain Group }\end{array}$ & $\begin{array}{l}\text { Nonwelded to densely welded ash-flow } \\
\text { tuff }\end{array}$ & Tma & 758.7 & 2,489 \\
\hline $1083.3-1184.5$ & $3,554-3,886$ & $\begin{array}{l}\text { Rhyolite of Tannenbaum Hill, } \\
\text { Timber Mountain Group }\end{array}$ & Rhyolite lava flow, flow breccia at top & Tmat & 101.2 & 332.0 \\
\hline $1184.5-1367.0$ & $3,886-4,485$ & $\begin{array}{l}\text { Landslide or eruptive breccia, } \\
\text { Rainier Mesa Tuff, Timber } \\
\text { Mountain Group }\end{array}$ & Nonwelded tuff and tuff breccia & Tmrx & 182.5 & 598.8 \\
\hline $1367.0-1441.7$ & $4,485-4,730$ & $\begin{array}{l}\text { Rainier Mesa Tuff, Timber } \\
\text { Mountain Group }\end{array}$ & Moderately welded ash-flow tuff & $\mathrm{Tmr}$ & 74.7 & 245.1 \\
\hline $\begin{array}{c}1441.7-1525.2 \\
\text { (TD) }\end{array}$ & $\begin{array}{c}4,730-5,004 \\
\text { (TD) }\end{array}$ & $\begin{array}{l}\text { Landslide or eruptive breccia, } \\
\text { Rainier mesa Tuff, Timber } \\
\text { Mountain Group }\end{array}$ & Tuff breccia & Tmrx & 83.5 & 274.0 \\
\hline
\end{tabular}

Source: Ferguson, et al., 1994. 


\section{Table C-8}

Abridged Drill Hole Statistics for Exploratory Hole UE-20e \#1

\section{Location Data:}

\begin{tabular}{|c|c|c|}
\hline \multirow[t]{2}{*}{ Coordinates: } & Central Nevada State Planar: & $\begin{array}{l}N 934,466 \mathrm{ft} \\
E 560,958 \mathrm{ft}\end{array}$ \\
\hline & Universal Transverse Mercator: & $\begin{array}{l}N 4,129,966.0 \mathrm{~m} \\
\mathrm{E} 548,122.8 \mathrm{~m}\end{array}$ \\
\hline$\cdot$ & Ground elevation: & $1,919.3 \mathrm{~m}(6,297 \mathrm{ft})$ \\
\hline & Static water level: & $\begin{array}{l}556.6 \mathrm{~m}(1,826 \mathrm{ft}) \\
\text { depth on } 04 / 05 / 75\end{array}$ \\
\hline
\end{tabular}

\section{Drilling Data:}

Spud date:

Total depth:

Drilling technique(s):
$03 / 26 / 64$

$1949.2 \mathrm{~m}(6,395 \mathrm{ft})$

This hole was rotary drilled and cored using air-mist and soap. A 66.0-cm (26-in.) hole was drilled to $7.0 \mathrm{~m}$ (23 ft). A 44.5-cm (17 1/2-in.) hole was drilled to $45.7 \mathrm{~m}(1,500 \mathrm{ft})$. A 31.1-cm (12 1/4-in.) hole was drilled to $502.9 \mathrm{~m}(1,650 \mathrm{ft})$. A 25.1-cm $(97 / 8-i n$.$) hole$ was drilled to $1946.2 \mathrm{~m}(6,385 \mathrm{ft})$. A $15.6-\mathrm{cm}$ (6 1/6-in.) hole was cored to $1949.2 \mathrm{~m}(6,395 \mathrm{ft})$. 33 intermittent cores were cut, typically in $3 \mathrm{~m}$ (10 ft) runs, using a conventional diamond core bit.

\section{Coring Data:}

Number of cores:

Total core recovered:

Percent of hole cored:

Cored interval(s):

Core size:
33 intermittent core runs

$80.6 \mathrm{~m}$ (264.5 ft); $75.8 \%$ recovery

$5.5 \%$

$402.3-1,949.2 m(1,320-6,395 \mathrm{ft})$. See Table $C-9$ in Appendix. $C$ for additional coring information.

8.9-cm (3 1/2-in.) diameter 
Table C-9

Coring Data for Exploratory Hole UE-20e \#1

\begin{tabular}{|c|c|c|c|c|c|}
\hline $\begin{array}{l}\text { Core Run } \\
\text { No. }\end{array}$ & $\begin{array}{c}\text { Depth Interval } \\
\text { (feet) }\end{array}$ & $\begin{array}{l}\text { Recovery } \\
\text { (feet) }\end{array}$ & $\begin{array}{l}\text { Stratigraphic } \\
\text { Unit }^{4}\end{array}$ & Lithology 2 & $\begin{array}{c}\text { Hydrostratigraphic } \\
\text { Unit }^{3}\end{array}$ \\
\hline $\begin{array}{l}\# 1 \\
\# 2 \\
\# 3\end{array}$ & $\begin{array}{l}1,320-1,330 \\
1,405-1,415 \\
1,415-1,434\end{array}$ & $\begin{array}{l}1.0 \\
.5 \\
1.0\end{array}$ & $\begin{array}{l}\text { Tmr } \\
\text { Tacp } \\
\text { Tacp }\end{array}$ & $\begin{array}{l}\quad \text { Tuff, PW } \\
\text { Rhyolite, lava flow } \\
\text { Rhyolite, lava flow }\end{array}$ & $\begin{array}{l}\text { TMA } \\
\text { TC } \\
\text { TC }\end{array}$ \\
\hline $\begin{array}{l}\# 4 \\
\# 5 \\
\# 6\end{array}$ & $\begin{array}{l}1,652-1,680 \\
1,710-1,720 \\
1,800-1,810\end{array}$ & $\begin{array}{l}00.0 \\
2.0 \\
2.5\end{array}$ & $\begin{array}{l}\text { Tacp } \\
\text { Tacp } \\
\text { Tacp }\end{array}$ & $\begin{array}{l}\text { Rhyolite, lava flow } \\
\text { Rhyolite, lava flow } \\
\text { Rhyolite, lava flow }\end{array}$ & $\begin{array}{l}\text { TC } \\
\text { TC } \\
\text { TC }\end{array}$ \\
\hline $\begin{array}{l}\# 7 \\
\# 8 \\
\# 9\end{array}$ & $\begin{array}{l}1,954-1,967 \\
2,120-2,130 \\
2,293-2,303\end{array}$ & $\begin{array}{l}13.0 \\
10.0 \\
7.0\end{array}$ & $\begin{array}{l}\text { Tacp } \\
\text { Tacp } \\
\text { Tacp }\end{array}$ & $\begin{array}{l}\text { Tuff, bedded } \\
\text { Rhyolite, lava flow } \\
\text { Rhyolite, lava flow }\end{array}$ & $\begin{array}{l}\text { TC } \\
\text { TC } \\
\text { TC }\end{array}$ \\
\hline $\begin{array}{l}\# 10 \\
\# 11 \\
\# 12\end{array}$ & $\begin{array}{l}2,500-2,510 \\
2,700-2,710 \\
2,950-2,960\end{array}$ & $\begin{array}{l}10.0 \\
10.0 \\
10.0\end{array}$ & $\begin{array}{l}\text { Tacp } \\
\text { Tacp } \\
\text { Tacp }\end{array}$ & $\begin{array}{c}\text { Flow breccia } \\
\text { Rhyolite, lava flow } \\
\text { Tuff, bedded }\end{array}$ & $\begin{array}{l}\text { TC } \\
\text { TC } \\
\text { TC }\end{array}$ \\
\hline $\begin{array}{l}\# 13 \\
\# 14 \\
\# 15\end{array}$ & $\begin{array}{l}3,150-3,160 \\
3,400-3,410 \\
3,520-3,530\end{array}$ & $\begin{array}{l}10.0 \\
10.0 \\
10.0\end{array}$ & $\begin{array}{l}\text { Tacp } \\
\text { Tacp } \\
\text { Tacp }\end{array}$ & $\begin{array}{c}\text { Tuff, NW, Z } \\
\text { Rhyolite, lava flow, Z } \\
\text { Rhyolite, lava flow, D }\end{array}$ & $\begin{array}{l}\text { TC } \\
\text { TC } \\
\text { TC }\end{array}$ \\
\hline $\begin{array}{l}\# 16 \\
\# 17 \\
\# 18\end{array}$ & $\begin{array}{l}3,700-3,710 \\
3,900-3,910 \\
4,100-4,110\end{array}$ & $\begin{array}{l}10.0 \\
10.0 \\
7.0\end{array}$ & $\begin{array}{l}\text { Tacp } \\
\text { Tacr } \\
\text { Tacr }\end{array}$ & $\begin{array}{l}\text { Tuff, bedded, Z } \\
\text { Tuff, NW, K } \\
\text { Tưff, NW, K }\end{array}$ & $\begin{array}{l}\text { TC } \\
\text { TC } \\
\text { TC }\end{array}$ \\
\hline $\begin{array}{l}\# 19 \\
\# 20 \\
\# 21\end{array}$ & $\begin{array}{l}4,150-4,153 \\
4,200-4,212 \\
4,250-4,260\end{array}$ & $\begin{array}{c}3.0 \\
12.0 \\
8.5\end{array}$ & $\begin{array}{c}\text { Tacr } \\
\text { Tap } \\
\text { Tai/Tcpj }\end{array}$ & $\begin{array}{l}\text { Tuff, bedded, } K \\
\text { Tuff, bedded, } Z \\
\text { Tuff, NW, Z }\end{array}$ & $\begin{array}{l}\text { TC } \\
\text { TC } \\
\text { TC }\end{array}$ \\
\hline $\begin{array}{l}\# 22 \\
\# 23 \\
\# 24 \\
\end{array}$ & $\begin{array}{l}4,300-4,310 \\
4,350-4,360 \\
4,400-4,410\end{array}$ & $\begin{array}{l}10.0 \\
10.0 \\
10.0 \\
\end{array}$ & $\begin{array}{l}\text { Tcpj } \\
\text { Tcpj } \\
\text { Tcpj } \\
\end{array}$ & $\begin{array}{c}\text { Tuff, NW, Z } \\
\text { Tuff, NW, Z } \\
\text { Tuff, bedded, Z } \\
\end{array}$ & $\begin{array}{l}\text { TC } \\
\text { TC } \\
\text { TC } \\
\end{array}$ \\
\hline $\begin{array}{l}\# 25 \\
\# 26 \\
\# 27 \\
\end{array}$ & $\begin{array}{l}4,450-4,460 \\
4,490-4,506 \\
4,680-4,690 \\
\end{array}$ & $\begin{array}{l}10.0 \\
16.0 \\
10.0 \\
\end{array}$ & $\begin{array}{l}\text { Tcpj } \\
\text { Tcpj } \\
\text { Tcpj }\end{array}$ & $\begin{array}{l}\text { Tuff, bedded, } Z \\
\text { Tuff, bedded, } Z \\
\text { Tuff, bedded, } Z\end{array}$ & $\begin{array}{l}\text { TC } \\
\text { TC } \\
\text { TC }\end{array}$ \\
\hline $\begin{array}{l}\# 28 \\
\# 29 \\
\# 30\end{array}$ & $\begin{array}{l}4,785-4,795 \\
5,092-5,102 \\
5,298-5,302\end{array}$ & $\begin{array}{l}10.0 \\
10.0 \\
3.5\end{array}$ & $\begin{array}{l}\text { Tcps } \\
\text { Tct } \\
\text { Tbdl }\end{array}$ & $\begin{array}{c}\text { Rhyolite, lava flow, D } \\
\text { Tuff, NW, Z } \\
\text { Rhyolite lava, P }\end{array}$ & $\begin{array}{l}\text { TC } \\
\text { TC } \\
\text { TBA }\end{array}$ \\
\hline $\begin{array}{l}\# 31 \\
\# 32 \\
\# 33 \\
\end{array}$ & $\begin{array}{l}5,468-5,472 \\
5,710-5,720 \\
6,385-6,395 \\
\end{array}$ & $\begin{array}{c}4.0 \\
10.0 \\
8.0 \\
\end{array}$ & $\begin{array}{r}\text { Tcl } \\
\text { Tbdl } \\
\text { Tbdk } \\
\end{array}$ & $\begin{array}{l}\text { Tuff, nonwelded, Z } \\
\text { Rhyolite, lava flow, D } \\
\text { Rhyolite, lava flow, D }\end{array}$ & $\begin{array}{l}\text { TBA } \\
\text { TBA } \\
\text { TBA }\end{array}$ \\
\hline
\end{tabular}

1 Refer to Table C-22 for explanation of stratigraphic nomenclature.

2 Refer to Table C-23 for explanation of lithologic nomenclature.

3 Refer to Table 1-4 for explanation of hydrostratigraphic nomenclature.

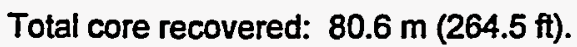

Static water level at $556.6 \mathrm{~m}(1,826 \mathrm{ft})$ depth.

Amount of core logged for this fracture study: All core recovered below $1,188.7 \mathrm{~m}(3,900 \mathrm{ft})$ depth, approximately $48 \mathrm{~m}$ (158 ft), minus core samples removed $(-20 \%)$ for previous unrelated studies. 
Table C-10

Condensed Stratigraphic and Lithologic Log for Exploratory Hole UE-20e \#1

(Page 1 of 3 )

\begin{tabular}{|c|c|c|c|c|c|c|}
\hline \multicolumn{2}{|c|}{ Depth } & \multirow{2}{*}{ Stratigraphic Unit } & \multirow{2}{*}{ Lithology } & \multirow{2}{*}{$\begin{array}{l}\text { Stratigraphic } \\
\text { Symbol }\end{array}$} & \multicolumn{2}{|c|}{ Thickness } \\
\hline Meters & Feet & & & & Meters & Feet \\
\hline $0-16.8$ & $0-55$ & $\begin{array}{l}\text { Trail Ridge Tuff, Thirsty Canyon } \\
\text { Group }\end{array}$ & $\begin{array}{l}\text { Partially to moderately welded ash-flow } \\
\text { tuff }\end{array}$ & Ttt & 16.8 & 55 \\
\hline $16.8-53.0$ & $55-174$ & $\begin{array}{l}\text { Pahute Mesa Tuff, Thirsty Canyon } \\
\text { Group }\end{array}$ & $\begin{array}{l}\text { Partially to moderately welded ash-flow } \\
\text { tuff }\end{array}$ & Ttp & 36.2 & 119 \\
\hline $53.0-105.2$ & $174-345$ & $\begin{array}{l}\text { Rocket Wash Tuff, Thirsty Canyon } \\
\text { Group }\end{array}$ & Partially welded ash-flow tuff & Ttr & 52.2 & 171 \\
\hline $105.2-156.4$ & $345-513$ & $\begin{array}{l}\text { Ammonia Tanks Tuff, Timber } \\
\text { Mountain Group }\end{array}$ & $\begin{array}{l}\text { Partially to moderately welded ash-flow } \\
\text { tuff }\end{array}$ & Tma & 51.2 & 168 \\
\hline $156.4-176.8$ & $513-580$ & $\begin{array}{l}\text { Bedded Ammonia Tanks Tuff, } \\
\text { Timber Mountain Groúp }\end{array}$ & Bedded tuff, vitric & Tmab & 20.4 & 67 \\
\hline $176.8-405.4$ & $580-1,330$ & $\begin{array}{l}\text { Rainier Mesa Tuff, Timber } \\
\text { Mountain Group }\end{array}$ & Partially to densely welded ash-flow tuff & $\mathrm{Tmr}$ & 228.6 & 750 \\
\hline $405.4-424.6$ & $1,330-1,393$ & $\begin{array}{l}\text { Tuff of Holmes Road, Timber } \\
\text { Mountain Group }\end{array}$ & Bedded tuff, zeolitized & Tmrh & 19.2 & 63 \\
\hline $424.6-594.6$ & $1,393-1,950$ & $\begin{array}{l}\text { Mafic-poor, Calico Hills Formation, } \\
\text { Volcanics of Area } 20\end{array}$ & $\begin{array}{l}\text { Lava flow, devitrified; pumiceous lava } \\
\text { below } 564 \mathrm{~m}\end{array}$ & Tacp & 170.0 & 557 \\
\hline $594.6-606.6$ & $1,950-1,990$ & $\begin{array}{l}\text { Mafic-poor, Calico Hills Formation, } \\
\text { Volcanics of Area } 20\end{array}$ & Bedded tuff, zeolitized & Tacp & 12.0 & 40 \\
\hline $606.6-885.4$ & $1,990-2,905$ & $\begin{array}{l}\text { Mafic-poor, Calico Hills Formation, } \\
\text { Volcanics of Area } 20\end{array}$ & Lava flow, devitrified & Tacp & 278.8 & 915 \\
\hline $885.4-1,021.1$ & $2,905-3,350$ & $\begin{array}{l}\text { Mafic-poor, Calico Hills Formation, } \\
\text { Volcanics of Area } 20\end{array}$ & Nonwelded ash-flow tuff, zeolitized & Tacp & 135.7 & 445 \\
\hline $1,021.1-1,127.8$ & $3,350-3,700$ & $\begin{array}{l}\text { Mafic-poor, Calico Hills Formation, } \\
\text { Volcanics of Area } 20\end{array}$ & Lava flow, devitrified to zeolitized & Tacp & 106.7 & 350 \\
\hline
\end{tabular}


Table C-10

Condensed Stratigraphic and Lithologic Log for Exploratory Hole UE-20e \#1

(Page 2 of 3 )

\begin{tabular}{|c|c|c|c|c|c|c|}
\hline \multicolumn{2}{|c|}{ Depth } & \multirow{2}{*}{ Stratigraphic Unit } & \multirow{2}{*}{ Lithology } & \multirow{2}{*}{$\begin{array}{l}\text { Stratigraphic } \\
\text { Symbol }\end{array}$} & \multicolumn{2}{|c|}{ Thickness } \\
\hline Meters & Feet & & & & Meters & Feet \\
\hline $1,127.8-1,187.5$ & $3,700-3,896$ & $\begin{array}{l}\text { Mafic-poor, Calico Hills Formation, } \\
\text { Volcanics of Area } 20\end{array}$ & Bedded tuff, zeolitized & Tacp & 59.7 & 196 \\
\hline $1,187.5-1,269.8$ & $3,896-4,166$ & $\begin{array}{l}\text { Mafic-rich, Calico Hills Formation, } \\
\text { Volcanics of Area } 20\end{array}$ & Bedded tuff, zeolitized & Tacr & 82.3 & 270 \\
\hline $1,269.8-1,290.8$ & $4,166-4,235$ & $\begin{array}{l}\text { Tuff of Pool, } \\
\text { Volcanics of Area } 20\end{array}$ & Bedded tuff, zeolitized & Tap & 21 & 69 \\
\hline $1,290.8-1,296.0$ & $4,235-4,252$ & $\begin{array}{l}\text { Rhyolite of Inlet, } \\
\text { Volcanics of Area } 20 \text {. }\end{array}$ & Bedded tuff, zeolitized & Tai & 5.2 & 17 \\
\hline $1,296.0-1,331.4$ & $4,252-4,368$ & $\begin{array}{l}\text { Tuff of Jorum, } \\
\text { Crater Flat Group }\end{array}$ & Nonwelded ash-flow tuff, zeolitized & Tcpj & 35.4 & 116 \\
\hline $1,331.4-1,446.6$ & $4,368-4,746$ & $\begin{array}{l}\text { Tuff of Jorum, } \\
\text { Crater Flat Group }\end{array}$ & Bedded tuff & Tcpj & 115.2 & 378 \\
\hline $1,446.6-1,548.4$ & $4,746-5,080$ & $\begin{array}{l}\text { Rhyolite of Sled, } \\
\text { Crater Flat Group }\end{array}$ & Lava flow, devitrified & Tcps & 101.8 & 334 \\
\hline $1,548.4-1,558.8$ & $5,080-5,114$ & $\begin{array}{l}\text { Tram Tuff, } \\
\text { Crater Flat Group }\end{array}$ & $\begin{array}{l}\text { Nonwelded ash-flow tuff, zeolitized } \\
:\end{array}$ & Tct & 10.4 & 34 \\
\hline $1,558.8-1,561.5$ & $5,114-5,123$ & $\begin{array}{l}\text { Comendite of Lambs Canyon, } \\
\text { Belted Range Group }\end{array}$ & Lava flow, devitrified & Tbdl & 2.7 & 9 \\
\hline $1,561.5-1,578.0$ & $5,123-5,177$ & $\begin{array}{l}\text { Comendite of Lambs Canyon, } \\
\text { Belted Range Group }\end{array}$ & Nonwelded ash-flow tuff, devitrified & Tbdl & 16.5 & 54 \\
\hline $1,578.0-1,620.0$ & $5,177-5,315$ & $\begin{array}{l}\text { Comendite of Lambs Canyon, } \\
\text { Belted Range Group }\end{array}$ & Lava flow, zeolitized to devitrified & Tbdl & 42 & 138 \\
\hline $1,620.0-1,668.2$ & $5,315-5,473$ & $\begin{array}{l}\text { Lower tuff, } \\
\text { Crater Flat Group }\end{array}$ & Bedded tuff, zeolitized & $\mathrm{TCl}$ & 48.2 & 158 \\
\hline
\end{tabular}


Table C-10

Condensed Stratigraphic and Lithologic Log for Exploratory Hole UE-20e \#1

.. (Page 3 of 3 )

\begin{tabular}{|c|c|c|c|c|c|c|}
\hline \multicolumn{2}{|c|}{ Depth } & \multirow{2}{*}{ Stratigraphic Unit } & \multirow{2}{*}{ Lithology } & \multirow{2}{*}{$\begin{array}{c}\text { Stratigraphic } \\
\text { Symbol }\end{array}$} & \multicolumn{2}{|c|}{ Thickness } \\
\hline Meters & Feet & & & & Meters & Feet \\
\hline $1,668.2-1,817.8$ & $5,473-5,964$ & $\begin{array}{l}\text { Comendite of Lambs Canyon, } \\
\text { Belted Range Group }\end{array}$ & Lava flow, devitrified to zeolitized & Tbdl & 149.6 & 491 \\
\hline $1,817.8-1,828.8$ & $5,964-6,000$ & $\begin{array}{l}\text { Comendite of Lambs Canyon, } \\
\text { Belted Range Group }\end{array}$ & Bedded tuff, zeolitized & Tbdl & 11 & 36 \\
\hline $\begin{array}{c}1,828.8-1,949.2 \\
\text { (TD) }\end{array}$ & $\begin{array}{c}6,000-6,395 \\
\text { (TD) }\end{array}$ & $\begin{array}{l}\text { Comendite of Kaw Station, Belted } \\
\text { Range Group }\end{array}$ & Lava flow, devitrified & Tbdk & 120.4 & 395 \\
\hline
\end{tabular}

Source: Ferguson, et al., 1994

$\stackrel{̊}{\stackrel{\omega}{\omega}}$ 
Location Data:

Coordinates: Central Nevada State Planar: N $908,250 \mathrm{ft}$

E 574,950 ft

Universal Transverse Mercator: $\quad$ N 4,122,010.0 m

E 552,406.1 m

Ground elevation: $\quad$. $\quad 2,022.8 \mathrm{~m}(6,636.6 \mathrm{ft})$

Static water level: $\quad 674.3 \mathrm{~m}(2,212 \mathrm{ft})$

depth on $06 / 03 / 93$

\section{Drilling Data:}

Spud date:

Total depth:

Drilling technique(s):
$08 / 27 / 91$

$856.5 \mathrm{~m}(2,810 \mathrm{ft})$

A 76.2-cm (30-in.) hole was drilled to $24.4 \mathrm{~m}$ (80 ft) using a hammer drill with air and air foam. $A$ $44.5-\mathrm{cm}(171 / 2-$ in.) hole was drilled to $591.6 \mathrm{~m}$ $(1,941 \mathrm{ft})$ using a hammer drill with air foam to $-102.1 \mathrm{~m}$ ( $335 \mathrm{ft}$ ), then air, water and soap. A $31.1-\mathrm{cm}(121 / 4$-in.) hole was drilled to total depth of $856.5 \mathrm{~m}(2,810 \mathrm{ft})$ using a hammer drill with air foam. Three cores were cut using a conventional $9.1-\mathrm{m}$ (30-ft) core barrel and a $22.2 \mathrm{~cm}$ (8 3/4-in.) Christensen diamond core bit.

\section{Coring Data:}

Number of cores:

Total core recovered:

.Percent of hole cored:

Cored interval(s):

Core size:
3 intermittent core runs

$18.7 \mathrm{~m}(61.3 \mathrm{ft}) ; 98.9 \%$ recovery

\section{$2.2 \%$}

$670.3 m-800.1 m(2,199-2,625.1 \mathrm{ft})$

See Table C-12 in Appendix C for additional coring . information.

10.2-cm (4-in.) diameter 
Table C-12

Coring Data for Monitoring Well UE-20bh \#1

\begin{tabular}{|c|c|c|c|c|c||}
\hline Core Run No. & $\begin{array}{c}\text { Depth Interval } \\
\text { (feet) }\end{array}$ & $\begin{array}{c}\text { Recovery } \\
\text { (feet) }\end{array}$ & Stratigraphic Unit ${ }^{1}$ & Lithology & $\begin{array}{c}\text { Hydrostratigraphic } \\
\text { Unit }^{2}\end{array}$ \\
\hline \hline$\# 1$ & $2,199-2,228$ & 29.0 & Tacp & Bedded Tuff, zeolitized & TC \\
$\# 2$ & $2,383-2,412$ & 28.3 & Tacp & Pumiceous Lava, zeolitized & TC \\
$\# 3$ & $2,621.1-2,625.1$ & 4.0 & Tacp & Lava &. \\
\hline
\end{tabular}

1 Refer to Table C-22 for stratigraphic nomenclature.

2 Refer to Table 1-4 for hydrostratigraphic nomenclature.

Total core recovered: $18.7 \mathrm{~m}(61.3 \mathrm{ft}) ; 98.9 \%$ recovery.

Amount of core logged for this fracture study: All core recovered $(18.7 \mathrm{~m})$ minus core samples removed $(\sim 10 \%)$ for previous unrelated studies.

Static water level at $674.7 \mathrm{~m}(2,214 \mathrm{ft})$. 
Table C-13

Condensed Stratigraphic and Lithologic.Log for Monitoring Well UE-20bh \#1.

\begin{tabular}{|c|c|c|c|c|c|c|}
\hline \multicolumn{2}{|c|}{ Depth } & \multirow{2}{*}{ Stratigraphic Unit } & \multirow{2}{*}{ Lithology } & \multirow{2}{*}{$\begin{array}{l}\text { Stratigraphic } \\
\text { Symbol }\end{array}$} & \multicolumn{2}{|c|}{ Thickness } \\
\hline Meters & Feet & & & & Meters & Feet \\
\hline $0.0-27.4$ & $0-90$ & No samples (behind surface casing) & -- & Tmr & 27.4 & 90 \\
\hline $27.4-113.1$ & $90-371$ & $\begin{array}{l}\text { Rainier Mesa Tuff, } \\
\text { Timber Mountain Group }\end{array}$ & $\begin{array}{l}\text { Nonwelded to densely welded ash-flow } \\
\text { tuff, vitric to devitrified }\end{array}$ & $\mathrm{Tmr}$ & 85.7 & 281 \\
\hline $113.1-134.1$ & $371-440$ & No samples & $\therefore$ & $\mathrm{Tm}$ & 21 & 69 \\
\hline $134.1-137.2$ & $440-450$ & $\begin{array}{l}\text { Tuff of Holmes Road, Timber Mountain } \\
\text { Group }\end{array}$ & Bedded tuff, vitric & Tmrh & 3.1 & 10 \\
\hline $137.2-.169 .2$ & $450-555$ & Paintbrush Group, undifferentiated & Bedded tuff, vitric & Tp & 32 & 105 \\
\hline $169.2-184.4$ & $555-605$ & $\begin{array}{l}\text { Mafic-poor, Calico Hills Formation, } \\
\text { Volcanics of Area } 20\end{array}$ & Bedded tuff, vitric & Tacp & 15.2 & 50 \\
\hline $184.4-224.0$ & $605-735$ & $\begin{array}{l}\text { Mafic-poor, Calico Hills Formation, } \\
\text { Volcanics of Area } 20\end{array}$ & Rhyolite lava flow, pumiceous, vitric & Tacp & 39.6 & 130 \\
\hline $224.0-416.4$ & $735-1,397$ & $\begin{array}{l}\text { Mafic-poor, Calico Hills Formation, } \\
\text { Volcanics of Area } 20\end{array}$ & Bedded fuff, zeolitized & Tacp & 192.4 & 631 \\
\hline $416.4-519.1$ & $1,397-1,703$ & $\begin{array}{l}\text { Mafic-poor, Calico Hills Formation, } \\
\text { Volcanics of Area } 20\end{array}$ & $\begin{array}{l}\text { Rhyolite lava flow, zeolitic pumiceous top, } \\
\text { devitrified middle, and vitric base }\end{array}$ & Tacp & 102.7 & 337 \\
\hline $519.1-725.4$ & $1,703-2,380$ & $\begin{array}{l}\text { Mafic-poor, Calico Hills Formation, } \\
\text { Volcanics of Area } 20\end{array}$ & Bedded tuff, zeollitized & Tacp & 206.3 & 677 \\
\hline $\begin{array}{l}725.4-856.5 \\
\text { (TD) }\end{array}$ & $\begin{array}{l}2,380-2,810 \\
\text { (TD) }\end{array}$ & $\begin{array}{l}\text { Mafic-poor, Calico Hills Formation, } \\
\text { Volcanics of Area } 20\end{array}$ & $\begin{array}{l}\text { Rhyolite lava flow, vitric to devitrified } \\
\text { zeolitic above } 783.3 \mathrm{~m}(2,570 \mathrm{ft})\end{array}$ & Tacp & 131.1 & 430 \\
\hline
\end{tabular}

Source: Modified from Boyd, et al., 1992. 
Table C-14

Abridged Drill Hole Statistics for Exploratory Hole UE-20c

\section{Location Data:}

Coordinates:

Central Nevada State Planar:

N 903,204 ft

$E 556,763 \mathrm{ft}$

Universal Transverse Mercator:

N 4,120,436.0 m

$\mathrm{E} 546,871.4 \mathrm{~m}$

Ground elevation:

Static water level:
$1,915.1 \mathrm{~m}(6,283 \mathrm{ft})$

$648.0 \mathrm{~m}(2,126 \mathrm{ft})$

\section{Drilling Data:}

Spud date:

Total depth:

Drilling technique(s):
$02 / 07 / 64$

$1630.1 \mathrm{~m}(5,348 \mathrm{ft})$

A 40-cm (17 1/2-in.).diameter hole was drilled from 10.1 to $198.1 \mathrm{~m}$ (33-650 ft). A 20-cm (9 \%-in.) diameter hole was drilled from 198.1 - 1,630.1 m $(650-5,348 \mathrm{ft})$. Air was used for circulation to $635.2 \mathrm{~m}(2,084 \mathrm{ft})$ and air with soap and water was used below $635.2 \mathrm{~m}(2,084 \mathrm{ft})$. Thirty-five intermittent conventional cores were taken from 137.2 to $1,573.1 \mathrm{~m}(450-5,161 \mathrm{ft})$.

\section{Coring Data:}

Number of cores:

Total core recovered:

Percent of hole cored:

Cored interval(s):

Core size:
35 intermittent core runs

$84.7 \mathrm{~m} \mathrm{(278} \mathrm{ft);} 90.4 \%$ recovery

\section{$5.7 \%$}

137.2 - 1,573.1 m (450 - 5,161 ft)

See Table C-15 in Appendix C for additional coring information

8.9-cm (3 1/2-in.) diameter 
Table C-15

Coring Data for Exploratory Hole UE-20c

\begin{tabular}{|c|c|c|c|c|c|}
\hline $\begin{array}{c}\text { Core } \\
\text { Rụn No. }\end{array}$ & $\begin{array}{c}\text { Depth Interval } \\
\text { (feet) }\end{array}$ & $\begin{array}{c}\text { Recovery } \\
\text { (feet) }\end{array}$ & $\begin{array}{c}\text { Stratigraphic } \\
\text { Unit }^{1}\end{array}$ & Lithology 2 & $\begin{array}{l}\text { Hydrostratigraphic } \\
\cdot \text { Unit }^{3}\end{array}$ \\
\hline $\begin{array}{l}\# 1 \\
\# 2 \\
\# 3\end{array}$ & $\begin{array}{l}450-455 \\
650-655 \\
820-830\end{array}$ & $\begin{array}{l}3.5 \\
3.0 \\
0.0\end{array}$ & $\begin{array}{l}\text { Tmr } \\
\text { Tmr } \\
\text { Tm }\end{array}$ & $\begin{array}{c}\text { Tuff, MW } \\
\text { Tuff, DW } \\
\text { Tuff, Bedded }\end{array}$ & $\begin{array}{l}\text { TMA } \\
\text { TMA } \\
\text { TMA }\end{array}$ \\
\hline $\begin{array}{l}\# 4 \\
\# 5 \\
\# 6\end{array}$ & $\begin{array}{l}1,185-1,195 \\
1,350-1,358 \\
1,500-1,508\end{array}$ & $\begin{array}{l}10.0 \\
6.0 \\
7.5\end{array}$ & $\begin{array}{l}\text { Tpb } \\
\text { Tpb } \\
\text { Tpb }\end{array}$ & $\begin{array}{l}\text { Lava } \\
\text { Lava } \\
\text { Lava }\end{array}$ & $\begin{array}{l}\text { TC } \\
\text { TC } \\
\text { TC }\end{array}$ \\
\hline $\begin{array}{l}\# 7 \\
\# 8 \\
\# 9\end{array}$ & $\begin{array}{l}1,716-1,724 \\
1,925-1,931 \\
2,125-2,133\end{array}$ & $\begin{array}{l}3.0 \\
6.0 \\
6.0\end{array}$ & $\begin{array}{c}\text { Tpb } \\
\text { Tpb } \\
\text { Tpcm }\end{array}$ & $\begin{array}{l}\text { Lava } \\
\text { Lava } \\
\text { Tuff, MW }\end{array}$ & $\begin{array}{l}\text { TC } \\
\text { TC } \\
\text { TC }\end{array}$ \\
\hline $\begin{array}{l}\# 10 \\
\# 11 \\
\# 12\end{array}$ & $\begin{array}{l}2,338-2,348 \\
2,550-2,560 \\
2,600-2,610\end{array}$ & $\begin{array}{l}10.0 \\
10.0 \\
10.0\end{array}$ & $\begin{array}{l}\text { Tpcm } \\
\text { Tptb } \\
\text { Tptb }\end{array}$ & $\begin{array}{l}\text { Tuff, MW } \\
\text { Tuff, Bedded } \\
\text { Tuff, Bedded }\end{array}$ & $\begin{array}{l}\text { TC } \\
\text { TC } \\
\text { TC }\end{array}$ \\
\hline $\begin{array}{l}\# 13 \\
\# 14 \\
\# 15 \\
\end{array}$ & $\begin{array}{l}2,650-2,676 \\
2,700-2,710 \\
2,750-2,760 \\
\end{array}$ & $\begin{array}{c}7.5 \\
10.0 \\
10.0 \\
\end{array}$ & $\begin{array}{l}\text { Tptb } \\
\text { Tptm } \\
\text { Tptm }\end{array}$ & $\begin{array}{l}\text { Tuff, Bedded } \\
\text { Tuff, MW } \\
\text { Tuff, MW }\end{array}$ & $\begin{array}{l}\text { TC } \\
\text { TC } \\
\text { TC }\end{array}$ \\
\hline $\begin{array}{l}\# 16 \\
\# 17 \\
\# 18 \\
\end{array}$ & $\begin{array}{l}2,800-2,810 \\
2,850-2,860 \\
2,900-2,910\end{array}$ & $\begin{array}{l}10.0 \\
10.0 \\
10.0 \\
\end{array}$ & $\begin{array}{l}\text { Tptm } \\
\text { Tptm } \\
\text { Tptm }\end{array}$ & $\begin{array}{l}\text { Tuff, MW } \\
\text { Tuff, MW } \\
\text { Tuff, MW }\end{array}$ & $\begin{array}{l}\text { TC } \\
\text { TC } \\
\text { TC }\end{array}$ \\
\hline $\begin{array}{l}\# 19 \\
\# 20 \\
\# 21 \\
\end{array}$ & $\begin{array}{l}2,950-2,960 \\
2,990-3,005 \\
3,100-3,110\end{array}$ & $\begin{array}{l}10.0 \\
15.0 \\
10.0\end{array}$ & $\begin{array}{l}\text { Tptm } \\
\text { Tptm } \\
\text { Tacp }\end{array}$ & $\begin{array}{c}\text { Tuff, MW } \\
\text { Tuff, MW } \\
\text { Tuff, Bedded }\end{array}$ & $\begin{array}{l}\text { TC } \\
\text { TC } \\
\text { TC }\end{array}$ \\
\hline $\begin{array}{l}\# 22 \\
\# 23 \\
\# 24 \\
\end{array}$ & $\begin{array}{l}3,200-3,210 \\
3,300-3,310 \\
3,400-3,410\end{array}$ & $\begin{array}{l}10.0 \\
10.0 \\
10.0\end{array}$ & $\begin{array}{l}\text { Tacp } \\
\text { Tacp } \\
\text { Tacp }\end{array}$ & $\begin{array}{l}\text { Tuff, Bedded } \\
\text { Tuff, Bedded } \\
\text { Tuff, Bedded }\end{array}$ & $\begin{array}{l}\text { TC } \\
\text { TC } \\
\text { TC }\end{array}$ \\
\hline $\begin{array}{l}\# 25 \\
\# 26 \\
\# 27 \\
\end{array}$ & $\begin{array}{l}3,503-3,513 \\
3,600-3,610 \\
3,700-3,710\end{array}$ & $\begin{array}{l}10.0 \\
10.0 \\
10.0\end{array}$ & $\begin{array}{l}\text { Tacp } \\
\text { Tacp } \\
\text { Tacp }\end{array}$ & $\begin{array}{c}\text { Tuff, Bedded } \\
\text { Tuff, Bedded } \\
\text { Lava }\end{array}$ & $\begin{array}{l}\text { TC } \\
\text { TC } \\
\text { TC }\end{array}$ \\
\hline $\begin{array}{l}\# 28 \\
\# 29 \\
\# 30 \\
\end{array}$ & $\begin{array}{l}3,900-3,906 \\
4,105-4,114 \\
4,240-4,242 \\
\end{array}$ & $\begin{array}{l}6.0 \\
1.5 \\
2.0 \\
\end{array}$ & $\begin{array}{l}\text { Tacp } \\
\text { Tacp } \\
\text { Tacp } \\
\end{array}$ & $\begin{array}{l}\text { Lava } \\
\text { Lava } \\
\text { Lava }\end{array}$ & $\begin{array}{l}\text { TC } \\
\text { TC } \\
\text { TC }\end{array}$ \\
\hline $\begin{array}{l}\# 31 \\
\# 32 \\
\# 33\end{array}$ & $\begin{array}{l}4,242-4,247 \\
4,537-4,545 \\
4,740-4,748\end{array}$ & $\begin{array}{l}5.0 \\
8.0 \\
8.0\end{array}$ & $\begin{array}{l}\text { Tacp } \\
\text { Tacp } \\
\text { Tacr }\end{array}$ & $\begin{array}{l}\quad \text { Lava } \\
\text { Tuff, Bedded } \\
\text { Tuff, Bedded }\end{array}$ & $\begin{array}{l}\text { TC } \\
\text { TC } \\
\text { TC }\end{array}$ \\
\hline $\begin{array}{l}\# 34 \\
\# 35\end{array}$ & $\begin{array}{l}4,935-4,945 \\
5,151-5,161 \\
\end{array}$ & $\begin{array}{r}10.0 \\
10.0 \\
\end{array}$ & $\begin{array}{l}\text { Tacr } \\
\text { Tacr }\end{array}$ & $\begin{array}{l}\text { Tuff, Bedded } \\
\text { Tuff, Bedded }\end{array}$ & $\begin{array}{l}\text { TC } \\
\text { TC }\end{array}$ \\
\hline
\end{tabular}

1 Refer to Table C-22 for explanation of stratigraphic nomenclature.

2 Refer to Table C-23 for explanation of lithologic nomenclature.

3 Refer to Table $1-4$ for explanation of hydrostratigraphic nomenclature.

Total core recovered: $84.7 \mathrm{~m}$ (278 ft).

Amount of core logged for this fracture study: All core recovered from below the static water level (72.8 $\mathrm{m}$ [239 ft]), minus core samples removed $(-20 \%)$ for previous unrelated studies.

Static water level at $648.0 \mathrm{~m}(2,126 \mathrm{ft})$. 


\section{Table C-16}

\section{Abridged Drill Hole Statistics for Exploratory Hole U-20c}

\section{Location Data:}

Coordinates: Central Nevada State Planar: $\quad$ N 903,296 ft

Universal Transverse Mercator: N 4,120,464.0 m

E 546,704.4 m

Ground elevation:

$1,914.4 \mathrm{~m}(6,281 \mathrm{ft})$

Static water level:

$639.2 \mathrm{~m}(2,099 \mathrm{ft})$

\section{Drilling Data:}

Spud date:

Total depth:

Drilling technique(s):
$06 / 26 / 64$

$1,463.0 \mathrm{~m}(4,800 \mathrm{ft})$

A 1.8-m (72-in.) diameter emplacement hole was drilled from 3.7 to $1,463.0 \mathrm{~m}$ (12 - 4,800 ft) using dual string reverse circulation with air, water, and soap. Six intermittent conventional cores were center punched from 1,386.5 - 1,463.0 m $(4,549-4,800 \mathrm{ft})$.

\section{Coring Data:}

Number of cores:

Total core recovered:

Percent of hole cored:

Core interval(s):

Core size:
6 intermittant core runs

$36.6 \mathrm{~m}$ (120 ft); $-100 \%$ recovery

$2.5 \%$

$1386.5-1,463.0 \dot{m}(4,549-4,800 \mathrm{ft})$ See Table C-17 in Appendix $C$ for additional coring information.

8.9-cm (3 1/2-in.) diameter 
Table C-17

Coring Data for Emplacement Hole U-20c

\begin{tabular}{|c|c|c|c|c|c|}
\hline $\begin{array}{l}\text { Core } \\
\text { Run No. }\end{array}$ & $\begin{array}{c}\text { Depth Interval } \\
\text { (feet) }\end{array}$ & $\begin{array}{c}\text { Recovery } \\
\text { (feet) }\end{array}$ & $\begin{array}{c}\text { Stratigraphic } \\
\text { Unit }^{T^{\prime}}\end{array}$ & Lithology & $\begin{array}{l}\text { Hydrostratigraphlc } \\
\text { Unit }^{2}\end{array}$ \\
\hline $\begin{array}{l}\# 1 \\
\# 2 \\
\# 3\end{array}$ & $\begin{array}{l}4,549-4,572 \\
4,591-4,607 \\
4,640-4,661\end{array}$ & $\begin{array}{l}23.0 \\
16.0 \\
21.0\end{array}$ & $\begin{array}{l}\text { Tacp } \\
\text { Tacp } \\
\text { Tacp }\end{array}$ & $\begin{array}{l}\text { Zeolitized bedded tuff } \\
\text { Zeolitized bedded tuff } \\
\text { Zeolitized bedded tuff }\end{array}$ & $\begin{array}{l}\text { TC } \\
\text { TC } \\
\text { TC }\end{array}$ \\
\hline $\begin{array}{l}\# 4 \\
\# 5 \\
\# 6\end{array}$ & $\begin{array}{l}4,690-4,710 \\
4,741-4,761 \\
4,780-4,800 \\
\end{array}$ & $\begin{array}{l}20.0 \\
20.0 \\
20.0\end{array}$ & $\begin{array}{l}\text { Tacp } \\
\text { Tacr } \\
\text { Tacr }\end{array}$ & $\begin{array}{l}\text { Zeolitized bedded tuff } \\
\text { Zeolitized bedded luff } \\
\text { Zeolitized bedded tuff }\end{array}$ & $\begin{array}{l}\text { TC } \\
\text { TC } \\
\text { TC }\end{array}$ \\
\hline
\end{tabular}

1 Refer to Table C-22 for explanation of stratigraphic nomenclature.

2 Refer to Table $1-4$ for explanation of hydrostratigraphic nomenclature.

Total core recovered: $36.6 \mathrm{~m}$ (120 ft); $100 \%$ recovery.

Amount of core logged for this study: All core recovered $(36.6 \mathrm{~m})$, minus core samples removed $(\sim 10 \%)$ for previous unrelated studies.

Static water level at $639.2 \mathrm{~m}(2,097 \mathrm{ft})$. 
Table C-18

Condensed Stratigraphic and Lithologic Log for Exploratory Hole UE-20c

(Page 1 of 2)

\begin{tabular}{|c|c|c|c|c|c|c|}
\hline \multicolumn{2}{|c|}{ Depth } & \multirow{2}{*}{ Stratigraphic Unit } & \multirow{2}{*}{ Lithology } & \multirow{2}{*}{$\begin{array}{c}\text { Stratigraphic } \\
\text { Symbol }\end{array}$} & \multicolumn{2}{|c|}{ Thickness } \\
\hline Meters & Feet & & & & Meters & Feet \\
\hline $0.0-19.5$ & $0-64$ & Trail Ridge Tuff, Thirsty Canyon Group & $\begin{array}{l}\text { Partially welded ash-flow tuff, } \\
\text { generally vitric }\end{array}$ & $\mathrm{Ttt}$ & 19.5 & 64 \\
\hline $19.5-48.8$ & $64-160$ & $\begin{array}{l}\text { Pahute Mesa Tuff, Thirsty Canyon } \\
\text { Group }\end{array}$ & $\begin{array}{l}\text { Partially welded ash-flow tuff, } \\
\text { generally vitric }\end{array}$ & Ttp & 29.3 & 96.1 \\
\hline $48.8-65.8$ & $160-216$ & $\begin{array}{l}\text { Rocket Wash Tuff, Thirsty Canyon } \\
\text { Group }\end{array}$ & $\begin{array}{l}\text { Partially welded ash-flow tuff, } \\
\text { generally vitric }\end{array}$ & $\operatorname{Ttr}$ & 17.0 & 55.8 \\
\hline $65.8-67.1$ & $216-220$ & $\begin{array}{l}\text { Beatty Wash Formation, Volcanics of } \\
\text { Fortymile Canyon }\end{array}$ & Bedded tuff, vitric & Tfb & 1.3 & 4.3 \\
\hline $67.1-132.6$ & $220-435$. & $\begin{array}{l}\text { Ammonia Tanks Tuff, Timber Mountain } \\
\text { Group }\end{array}$ & $\begin{array}{l}\text { Partially welded ash-flow tuff, } \\
\text { generally vitric }\end{array}$ & Tma & 65.5 & 214.9 \\
\hline $132.6-134.7$ & $435-442$ & $\begin{array}{l}\text { Bedded Ammonia Tanks Tuff, Timber } \\
\text { Mountain Group }\end{array}$ & Bedded tuff, vitric & Tmab & 2.1 & 6.9 \\
\hline $134.7-246.9$ & $442-810$ & $\begin{array}{l}\text { Rainier Mesa Tuff, Timber Mountain } \\
\text { Group }\end{array}$ & $\begin{array}{l}\text { Nonwelded to densely welded ash- } \\
\text { flow tuff, vitric to devitrified }\end{array}$ & Tmr & 112.2 & 368.1 \\
\hline $246.9-289.6$ & $810-950$ & $\begin{array}{l}\text { Timber Mountain Group, } \\
\text { undifferentiated }\end{array}$ & Bedded tuff, vitric & $\mathrm{Tm}$ & 42.7 & 140.1 \\
\hline $289.6-643.1$ & $950-2,110$ & Rhyolite of Benham, Paintbrush Group & $\begin{array}{l}\text { Mostly rhyolite lava, pumiceous laval } \\
\text { top and bottom, with thin bedded } \\
\text { tuff at base }\end{array}$ & Tpb & 353.5 & $1,159.8$ \\
\hline $643.1-749.8$ & $2,110-2,460$ & Tiva Canyon Tuff, Paintbrush Group & $\begin{array}{l}\text { Partially to densely welded ash-flow } \\
\text { tuff, generally devitrified }\end{array}$ & Tpcm & 106.7 & 350.1 \\
\hline $749.8-768.1$ & $2,460-2,520$ & Paintbrush Group, undifferentiated & Bedded tuff, zeolitized & $T p$ & 18.3 & 60.0 \\
\hline $768.1-792.5$ & $2,520-2,600$ & $\begin{array}{l}\text { Bedded Topopah Spring Tuff, } \\
\text { Paintbrush Group }\end{array}$ & Bedded tuff, zeolitized & Tptb & 24.4 & 80.1 \\
\hline
\end{tabular}


Table C-18

Condensed Stratigraphic and Lithologic Log for Exploratory Hole UE-20c

(Page 2 of 2)

\begin{tabular}{|c|c|c|c|c|c|c|}
\hline \multicolumn{2}{|c|}{ Depth } & \multirow{2}{*}{ Stratigraphic Unit } & \multirow{2}{*}{ Lithology } & \multirow{2}{*}{$\begin{array}{c}\text { Stratigraphic } \\
\text { Symbol }\end{array}$} & \multicolumn{2}{|c|}{ Thickness } \\
\hline Meters & Feet & & & & Meters & Feet \\
\hline $792.5-929.6$ & $2,600-3,050$ & $\begin{array}{l}\text { Pahute Mesa lobe, Topopah Spring } \\
\text { Tuff, Paintbrush Group }\end{array}$ & $\begin{array}{l}\text { Nonwelded to moderately welded } \\
\text { ash-flow tuff, generally devitrified }\end{array}$ & Tptm & 137.1 & 449.8 \\
\hline $929.6-1,106.4$ & $3,050-3,630$ & $\begin{array}{l}\text { Mafic-poor, Calico Hills Formation, } \\
\text { Volcanics of Area } 20\end{array}$ & Bedded tuff, zeolitized & Tacp & 176.8 & 580.1 \\
\hline $1,106.4-1,258.8$ & $3,630-4,130$ & $\begin{array}{l}\text { Mafic-poor, Calico Hills Formation, } \\
\text { Volcanics of Area } 20\end{array}$ & Rhyolite lava flow & Tacp & 152.4 & 500.0 \\
\hline $1,258.8-1,261.9$ & $4,130-4,140$ & $\begin{array}{l}\text { Mafic-poor, Calico Hills Formation, } \\
\text { Volcanics of Area } 20\end{array}$ & Bedded tuff, zeolitized & Tacp & 3.1 & 10.2 \\
\hline $1,261.9-1,368.6$ & $4,140-4,490$ & $\begin{array}{l}\text { Mafic-poor, Calico Hills Formation, } \\
\text { Volcanics of Area } 20\end{array}$ & Rhyolite lava flow & Tacp & 106.7 & 350.1 \\
\hline $1,368.6-1,386.8$ & $4,490-4,550$ & $\begin{array}{l}\text { Mafic-poor, Calico Hills Formation, } \\
\text { Volcanics of Area } 20\end{array}$ & Bedded tuff, zeolitized & Tacp & 18.2 & 59.7 \\
\hline $\begin{array}{c}1,386.8-1,630.1 \\
\text { (TD) }\end{array}$ & $\begin{array}{c}4,550-5,348 \\
\text { (TD) }\end{array}$ & $\begin{array}{l}\text { Mafic-rich, Calico Hills Formation, } \\
\text { Volcanics of Area } 20\end{array}$ & Bedded tuff, zeolitized & Tacr & 243.3 & 798.3 \\
\hline
\end{tabular}

Source: Ferguson, et al., 1994 


\section{Location Data:}

\begin{tabular}{|c|c|c|}
\hline \multirow[t]{4}{*}{ Coordinates: } & Central Nevada State Planar: & $\begin{array}{l}\text { N } 917,825 \mathrm{ft} \\
\mathrm{E} 552,007 \mathrm{ft}\end{array}$ \\
\hline & Universal Transverse Mercator: & $\begin{array}{l}\mathrm{N} 4,124,897.0 \mathrm{~m} \\
\mathrm{E} 545,393.3 \mathrm{~m}\end{array}$ \\
\hline & Ground elevation: & $1,864.2 \mathrm{~m}(6,116 \mathrm{ft})$ \\
\hline & Static water level: & $\begin{array}{l}595.6 \mathrm{~m}(1,954 \mathrm{ft}) \text { depth with hole at } \\
1,384.7 \mathrm{~m}(4,543 \mathrm{ft}) .537 .4 \mathrm{~m} \\
(1,763 \mathrm{ft}) \text { depth with hole at TD of } \\
4,171.5 \mathrm{~m}(13,686 \mathrm{ft})\end{array}$ \\
\hline
\end{tabular}

\section{Drilling Data:}

Spud date:

Total depth:

Drilling technique(s):

\section{3/03/64}

$4,17.1 .5 \mathrm{~m}(13,686 \mathrm{ft})$

A 66.0-cm (26-in.) hole was rotary drilled to $9.1 \mathrm{~m}$ (30 ft). A 44.5-cm (17 1/2-in.) hole was rotary drilled to $224.0 \mathrm{~m}$ (735 ft). A 31.1-cm (12 1/4-in.) hole was rotary drilled to $1,380.7 \mathrm{~m}(4,530 \mathrm{ft})$. A 22.2-cm ( $83 / 4$-in.) hole was rotary drilled to $4,466.6 \mathrm{~m}$ $(13,670 \mathrm{ft})$. A 15.6-cm (6 1/8-in.) bottom hole core was obtained to total depth of $4,171.5 \mathrm{~m}(13,686 \mathrm{ft})$. This hole was drilled with air to $453.2 \mathrm{~m}(1,487 \mathrm{ft})$, then with air, soap and water from $453.2 \mathrm{~m}(1,487 \mathrm{ft})$ to TD. 50 intermittent cores were cut (typically in 8to $10-\mathrm{ft}$ runs) at various depths between 225.2 $4,171.5 \mathrm{~m}(739-13,686 \mathrm{ft})$.

Coring Data:

Number of cores:

Total core recovered:

Percent of hole cored:

Cored interval(s):

Core size:
50 intermittent core runs

$120.1 \mathrm{~m}$ (394 ft); $94.1 \%$ recovery

$3.1 \%$

$225.2-4,171.5 m(739-13,686 \mathrm{ft})$

See Table $\mathrm{C}-20$ for additional coring information

8.9-cm (3 1/2-in.) diameter 
Table C-20

Coring Data for Exploratory Hole UE-20f

(Page 1 of 2)

\begin{tabular}{|c|c|c|c|c|c|}
\hline $\begin{array}{c}\text { Core Run } \\
\text { No. }\end{array}$ & $\begin{array}{c}\text { Depth Interval } \\
\text { (feet) }\end{array}$ & $\begin{array}{c}\text { Recovery } \\
\text { (feet) }\end{array}$ & $\begin{array}{c}\text { Stratigraphic } \\
\text { Unit }^{1}\end{array}$ & Lithology 2 & $\begin{array}{c}\text { Hydrostratigraphic } \\
\text { Unit }^{3}\end{array}$ \\
\hline $\begin{array}{l}\# 1 \\
\# 2 \\
\# 3\end{array}$ & $\begin{array}{c}739-747 \\
976-986 \\
1,185-1,195\end{array}$ & $\begin{array}{c}5.0 \\
8.0 \\
10.0\end{array}$ & $\begin{array}{l}\text { Tmr } \\
\text { Tmr } \\
\text { Tmr }\end{array}$ & $\begin{array}{l}\text { Tuff, MW } \\
\text { Tuff, MW } \\
\text { Tuff, MW }\end{array}$ & $\begin{array}{l}\text { TMA } \\
\text { TMA } \\
\text { TMA }\end{array}$ \\
\hline $\begin{array}{l}\# 4 \\
\# 5 \\
\# 6\end{array}$ & $\begin{array}{l}1,400-1,405 \\
1,587-1,597 \\
1,771-1,781\end{array}$ & $\begin{array}{c}5.0 \\
10.0 \\
10.0\end{array}$ & $\begin{array}{l}\text { Tmr } \\
\text { Tmr } \\
\text { Tmr }\end{array}$ & $\begin{array}{l}\text { Tuff, MW } \\
\text { Tuff, NW, V } \\
\text { Tuff, NW, V }\end{array}$ & $\begin{array}{l}\text { TMA } \\
\text { TMA } \\
\text { TMA }\end{array}$ \\
\hline $\begin{array}{l}\# 7 \\
\# 8 \\
\# 9 .\end{array}$ & $\begin{array}{l}1,985-1,995 \\
2,198-2,208 \\
2,413-2,423\end{array}$ & $\begin{array}{l}10.0 \\
10.0 \\
10.0\end{array}$ & $\begin{array}{l}\text { Tmri } \\
\text { Tmri } \\
\text { Tmw }\end{array}$ & $\begin{array}{l}\text { Tuff, reworked, Z } \\
\text { Tuff, reworked, Z } \\
\text { Tuff, reworked, Z }\end{array}$ & $\begin{array}{l}\text { TMA } \\
\text { TMA } \\
\text { TMA }\end{array}$ \\
\hline $\begin{array}{l}\# 10 \\
\# 11 \\
\# 12\end{array}$ & $\begin{array}{l}2,618-2,628 \\
2,838-2,848 \\
3,020-3,030\end{array}$ & $\begin{array}{l}10.0 \\
10.0 \\
10.0\end{array}$ & $\begin{array}{l}\text { Tpcm } \\
\text { Tptm } \\
\text { Tacp }\end{array}$ & $\begin{array}{l}\text { Tuff, MW } \\
\text { Tuff, NW, D } \\
\text { Tuff, NW, Z }\end{array}$ & $\begin{array}{l}\text { TC } \\
\text { TC } \\
\text { TC }\end{array}$ \\
\hline $\begin{array}{l}\# 13 \\
\# 14 \\
\# 15\end{array}$ & $\begin{array}{l}3,232-3,237 \\
3,431-3,441 \\
3,600-3,608\end{array}$ & $\begin{array}{l}5.0 \\
7.0 \\
8.0\end{array}$ & $\begin{array}{l}\text { Tacp } \\
\text { Tacp } \\
\text { Tacr }\end{array}$ & $\begin{array}{l}\text { Lava, D } \\
\text { Lava, D } \\
\text { Lava, D }\end{array}$ & $\begin{array}{l}\text { TC } \\
\text { TC } \\
\text { TC }\end{array}$ \\
\hline $\begin{array}{l}\# 16 \\
\# 17 \\
\# 18\end{array}$ & $\begin{array}{l}3,647-3,655 \\
3,700-3,708 \\
3,750-3,758\end{array}$ & $\begin{array}{l}8.0 \\
8.0 \\
8.0\end{array}$ & $\begin{array}{l}\text { Tacr } \\
\text { Tacr } \\
\text { Tacr }\end{array}$ & $\begin{array}{c}\text { Tuff, reworked, Z } \\
\text { Tuff, NW, Z } \\
\text { Tuff, NW, Z }\end{array}$ & $\begin{array}{l}\text { TC } \\
\text { TC } \\
\text { TC }\end{array}$ \\
\hline $\begin{array}{l}\# 19 \\
\# 20 \\
\# 21\end{array}$ & $\begin{array}{l}3,800-3,808 \\
3,850-3,858 \\
3,900-3,908\end{array}$ & $\begin{array}{l}8.0 \\
8.0 \\
8.0\end{array}$ & $\begin{array}{l}\text { Tacr } \\
\text { Tacr } \\
\text { Tacr }\end{array}$ & $\begin{array}{l}\text { Tuff, NW, Z } \\
\text { Tuff, NW, Z } \\
\text { Tuff, NW, Z }\end{array}$ & $\begin{array}{l}\text { TC } \\
\text { TC } \\
\text { TC }\end{array}$ \\
\hline $\begin{array}{l}\# 22 \\
\# 23 \\
\# 24\end{array}$ & $\begin{array}{r}3,948-3,956 \\
3,990-4,009 \\
4,083-4,091\end{array}$ & $\begin{array}{c}8.0 \\
19.0 \\
8.0\end{array}$ & $\begin{array}{l}\text { Tacr } \\
\text { Tacr } \\
\text { Tacr }\end{array}$ & $\begin{array}{c}\text { Tuff, NW, Z } \\
\text { Tuff, NW, Z } \\
\text { Bedded tuff, Z }\end{array}$ & $\begin{array}{l}\text { TC } \\
\text { TC } \\
\text { TC }\end{array}$ \\
\hline $\begin{array}{l}\# 25 \\
\# 26 \\
\# 27\end{array}$ & $\begin{array}{l}4,152-4,160 \\
4,535-4,543 \\
4,731-4,741\end{array}$ & $\begin{array}{c}8.0 \\
8.0 \\
10.0\end{array}$ & $\begin{array}{l}\text { Tacr } \\
\text { Tacr } \\
\text { Tai }\end{array}$ & $\begin{array}{l}\text { Bedded tuff, Z } \\
\text { Lava, D/gi } \\
\text { Flow breccia, D }\end{array}$ & $\begin{array}{l}\text { TC } \\
\text { TC } \\
\text { TC }\end{array}$ \\
\hline $\begin{array}{l}\# 28 \\
\# 29 \\
\# 30\end{array}$ & $\begin{array}{l}5,066-5,069 \\
5,287-5,293 \\
5,796-5,806\end{array}$ & $\begin{array}{c}3.0 \\
6.0 \\
10.0 \\
\end{array}$ & $\begin{array}{l}\text { Tai } \\
\text { Tai } \\
\text { Tcpj }\end{array}$ & $\begin{array}{l}\text { Tuff, MW } \\
\text { Flow breccia, D } \\
\text { Tuff, bedded, Z }\end{array}$ & $\begin{array}{l}\text { TC } \\
\text { TC } \\
\text { TC }\end{array}$ \\
\hline $\begin{array}{l}\# 31 . \\
\# 32 \\
\# 33\end{array}$ & $\begin{array}{l}6,000-6,009 \\
6,208-6,209 \\
6,300-6,302\end{array}$ & $\begin{array}{l}9.0 \\
1.0 \\
2.0\end{array}$ & $\begin{array}{l}\text { Tcpj } \\
\text { Tcblp } \\
\text { Tcblp }\end{array}$ & $\begin{array}{c}\text { Tuff, bedded, Z } \\
\text { Tuff, NW, Z } \\
\text { Tuff, NW, Z }\end{array}$ & $\begin{array}{l}\text { TC } \\
\text { TCB } \\
\text { TCB }\end{array}$ \\
\hline $\begin{array}{l}\# 34 \\
\# 35 \\
\# 36\end{array}$ & $\begin{array}{l}6,442-6,452 \\
6,655-6,665 \\
6,855-6,865\end{array}$ & $\begin{array}{l}10.0 \\
10.0 \\
10.0\end{array}$ & $\begin{array}{l}\text { Tcblp } \\
\text { Tcblp } \\
\text { Tcblp }\end{array}$ & $\begin{array}{l}\text { Tuff, NW, Z } \\
\text { Tuff, NW, Z } \\
\text { Tuff, NW, Z }\end{array}$ & $\begin{array}{l}\text { TCB } \\
\text { TCB } \\
\text { TCB }\end{array}$ \\
\hline $\begin{array}{l}\# 37 \\
\# 38 \\
\# 39\end{array}$ & $\begin{array}{l}7,165-7,175 \\
7,268-7,278 \\
7,563-7,573\end{array}$ & $\begin{array}{l}10.0 \\
10.0 \\
10.0\end{array}$ & $\begin{array}{l}\text { Tcblp } \\
\text { Tcblp } \\
\text { Tcblp }\end{array}$ & $\begin{array}{l}\text { Tuff, NW, Z } \\
\text { Tuff, NW, Z } \\
\text { Tuff, NW, Z }\end{array}$ & $\begin{array}{l}\text { TCB } \\
\text { TCB } \\
\text { TCB }\end{array}$ \\
\hline
\end{tabular}




\section{Table C-20 \\ Coring Data for Exploratory Hole UE-20f}

(Page 2 of 2)

\begin{tabular}{|c|c|c|c|c|c|}
\hline $\begin{array}{c}\text { Core Run } \\
\text { No. } \\
\end{array}$ & $\begin{array}{c}\text { Depth Interval } \\
\text { (feet) }\end{array}$ & $\begin{array}{c}\text { Recovery } \\
\text { (feet) }\end{array}$ & $\begin{array}{c}\text { Stratigraphic } \\
\text { Unit }^{1}\end{array}$ & Lithology 2 & $\begin{array}{c}\text { Hydrostratigraphic } \\
\text { Unit }^{3}\end{array}$ \\
\hline $\begin{array}{l}\# 40 \\
\# 41 \\
\# 42\end{array}$ & $\begin{array}{l}7,731-7,739 \\
7,930-7,940 \\
7,975-7,984\end{array}$ & $\begin{array}{c}8.0 \\
10.0 \\
9.0\end{array}$ & $\begin{array}{l}\text { Tcblp } \\
\text { Tcblp } \\
\text { Tcblp }\end{array}$ & $\begin{array}{l}\text { Tuff, NW, Z } \\
\text { Tuff, NW, Z } \\
\text { Tuff, NW, Z }\end{array}$ & $\begin{array}{l}\text { TCB } \\
\text { TCB } \\
\text { TCB }\end{array}$ \\
\hline $\begin{array}{l}\# 43 \\
\# 44 \\
\# 45 \\
\end{array}$ & $\begin{array}{l}8,097-8,107 \\
8,380-8,385 \\
8,665-8,668 \\
\end{array}$ & $\begin{array}{c}10.0 \\
5.0 \\
2.0 \\
\end{array}$ & $\begin{array}{l}\text { Tcblp } \\
\text { Tbdl } \\
\text { Tbdk } \\
\end{array}$ & $\begin{array}{c}\text { Tuff, NW, Z } \\
\text { Lava, D } \\
\text { Flow breccia, D } \\
\end{array}$ & $\begin{array}{l}\text { TCB } \\
\text { TBA. } \\
\text { TBA }\end{array}$ \\
\hline $\begin{array}{l}\# 46 \\
\# 47 \\
\# 48 \\
\end{array}$ & $\begin{array}{c}9,050-9052 \\
10,195-10,199 \\
12,230-12,237 \\
\end{array}$ & $\begin{array}{l}1.5 \\
4.0 \\
0.0 \\
\end{array}$ & $\begin{array}{c}\text { Tbdk } \\
\text { Tub } \\
\text { To } \\
\end{array}$ & $\begin{array}{c}\text { Flow breccia, D } \\
\text { Flow breccia, Z } \\
\text { Lava, D }\end{array}$ & $\begin{array}{l}\text { TBA } \\
\text { TBA } \\
\text { BAQ }\end{array}$ \\
\hline $\begin{array}{l}\# 49 \\
\# 50 \\
\end{array}$ & $\begin{array}{c}12,644-12,644.5 \\
13,607-13,686 \\
\end{array}$ & $\begin{array}{l}0.38 \\
16.0 \\
\end{array}$ & $\begin{array}{l}\text { To } \\
\text { To }\end{array}$ & $\begin{array}{c}\text { Lava, D } \\
\text { Tuff, MW, D }\end{array}$ & $\begin{array}{l}B A Q \\
B A Q\end{array}$ \\
\hline
\end{tabular}

1 Refer to Table C-22 for explanation of stratigraphic nomenclature.

2 Refer to Table C-23 for explanation of lithologic nomenclature.

3 Refer to Table $1-4$ for explanation of hydrostratigraphic nomenclature.

Total core recovered: $120 \mathrm{~m}$ (394 ft).

Static water level at $595.6 \mathrm{~m}(1,954 \mathrm{ft})$ with TD at $1,384.7 \mathrm{~m}(4,543 \mathrm{ft})$.

Static water level at $537.4 \mathrm{~m}(1,763 \mathrm{ft})$ with TD at 4,171.5 $\mathrm{m}(13,686 \mathrm{ft})$.

Amount of core logged for this fracture study: All core recovered below $798 \mathrm{~m}(2,618 \mathrm{ft})$, approximately $95.7 \mathrm{~m}$ $(314 \mathrm{ft})$, minus core samples removed $(-20 \%)$ for previous unrelated studies. 
Table C-21

Condensed Stratigraphic and Lithologic Log for Exploratory Hole UE-20f

(Page 1 of 3 )

\begin{tabular}{|c|c|c|c|c|c|c|}
\hline \multicolumn{2}{|c|}{ Depth } & \multirow{2}{*}{ Stratigraphic Unit } & \multirow{2}{*}{ Lithology } & \multirow{2}{*}{$\begin{array}{l}\text { Stratigraphic } \\
\text { Symbol }\end{array}$} & \multicolumn{2}{|c|}{ Thickness } \\
\hline Meters & Feet & & & & Meters & Feet \\
\hline $0.0-31.4$ & $0-103$ & Trail Ridge Tuff, Thirsty Canyon Group & $\begin{array}{l}\text { Partially to moderately welded ash-fiow } \\
\text { tuff, bedded interval at base }\end{array}$ & $T H$ & 31.4 & 103 \\
\hline $31.4-46.9$. & $103-154$ & Pahute Mesa Tuff, Thirsty Canyon Group & $\begin{array}{l}\text { Partially to moderately welded ash-flow } \\
\text { tuff }\end{array}$ & Ttp & .15 .5 & 51 \\
\hline $46.9-100.6$ & $154-330$ & $\begin{array}{l}\text { Rocket Wash Tuff, Thirsty Canyon } \\
\text { Group }\end{array}$ & $\begin{array}{l}\text { Partially to moderately welded ash-flow } \\
\text { tuff }\end{array}$ & Ttr & 53.7 & 176 \\
\hline $100.6-186.2$ & $330-611$ & $\begin{array}{l}\text { Ammonia Tanks Tuff, Timber Mountain } \\
\text { Group }\end{array}$ & $\begin{array}{l}\text { Nonwelded to densely welded ash-fiow } \\
\text { tuff }\end{array}$ & Tma & 85.6 & 281 \\
\hline $186.2-210.3$ & $611-690$ & $\begin{array}{l}\text { Bedded Ammonia Tanks Tuff, Timber } \\
\text { Mountain Group }\end{array}$ & Bedded tuff, vitric & Tmab & 24.1 & 79 \\
\hline $210.3-458.1$ & $690-1,503$ & $\begin{array}{l}\text { Rainier Mesa Tuff, Timber Mountain } \\
\text { Group }\end{array}$ & Partially to densely welded ash-flow tuff & Tmr & 247.8 & 813 \\
\hline $458.1-594.1$ & $1,503-1,949$ & $\begin{array}{l}\text { Rhyolite of Fluorspar Canyon, Timber } \\
\text { Mountain Group }\end{array}$ & $\begin{array}{l}\text { Nonwelded ash-flow tuff with bedded } \\
\text { interval at base }\end{array}$ & Tmrf & 136 & 446 \\
\hline $594.1-730.9$ & $1,949-2,398$ & $\begin{array}{l}\text { Tuff of Holmes Road, Timber Mountain } \\
\text { Group . }\end{array}$ & Bedded tuff, zeolitized & Tmrh & 136.8 & 449 \\
\hline $730.9-752.9$ & $2,398-2,470$ & $\begin{array}{l}\text { Rhyolite of Windy Wash, Timber } \\
\text { Mountain Group }\end{array}$ & Reworked and bedded tuff, zeolitized & Tmw & 22 & 72 \\
\hline $752.9-793.7$ & $2,470-2,604$ & Rhyolite of Benham, Paintbrush Group & Bedded tuff & $\mathrm{Tpb}$ & 40.8 & 134 \\
\hline $793.7-830.0$ & $2,604-2,723$ & Tiva Canyon Tuff, Paintbrush Group & $\begin{array}{l}\text { Moderately to densely welded ash-flow } \\
\text { tuff, devitrified. }\end{array}$ & Tpcm & 36.3 & 119 \\
\hline $830.0-864.1$ & $2,723-2,835$ & $\begin{array}{l}\text { Rhyolite of Delirium Canyon, Paintbrush } \\
\text { Group }\end{array}$ & Bedded tuff & Tpd & 34.1 & 112 \\
\hline $864.1-899.2$ & $2,835-2,950$ & Topopah Spring Tuff, Paintbrush Group & Nonwelded ash-flow tuff, devitrified & Tptm & 35.1 & 115 \\
\hline $899.2-924.8$ & $2,950-3,034$ & $\begin{array}{l}\text { Mafic-poor, Calico Hills Formation, } \\
\text { Volcanics of Area } 20\end{array}$ & Bedded tuff, zeolitized & Tacp & 25.6 & 84 \\
\hline
\end{tabular}


Table C-21

Condensed Stratigraphic and Lithologic Log for Exploratory Hole UE-20f.

(Page 2 of 3)

\begin{tabular}{|c|c|c|c|c|c|c|}
\hline \multicolumn{2}{|c|}{ Depth } & \multirow{2}{*}{ Stratigraphic Unit } & \multirow{2}{*}{ Lithology } & \multirow{2}{*}{$\begin{array}{l}\text { Stratigraphic } \\
\text { Symbol }\end{array}$} & \multicolumn{2}{|c|}{ Thlckness } \\
\hline Meters & Feet & & & & Meters & Feet \\
\hline $924.8-1,066.8$ & $3,034-3,500$ & $\begin{array}{l}\text { Mafic-poor, Calico Hills Formation, } \\
\text { Volcanics of Area } 20\end{array}$ & Lavạ flow, devitrified & Tacp & 142 & 466 \\
\hline $1,066.8-1,106.4$ & $3,500-3,630$ & $\begin{array}{l}\text { Mafic-rich, Calico Hills Formation, } \\
\text { Volcanics of Area } 20\end{array}$ & Lava flow, devitrified & Tacr & 39.6 & 130 \\
\hline $1,106.4-1,116.5$ & $3,630-3,663$ & $\begin{array}{l}\text { Mafic-rich, Calico Hills Formation, } \\
\text { Volcanics of Area } 20\end{array}$ & Reworded tuff, zeolitized & Tacr & 10.1 & 33 \\
\hline $1,116.5-1,323.8$ & $3,663-4,343$ & $\begin{array}{l}\text { Mafic-rich, Calico Hills Formation, } \\
\text { Volcanics of Area } 20\end{array}$ & $\begin{array}{l}\text { Nonwelded and bedded tuff, zeolitized, } \\
\text { pumiceous lava at base }\end{array}$ & Tacr & 207.3 & 680 \\
\hline $1,323.8-1,450.9$ & $4,343-4,760$ & $\begin{array}{l}\text { Rhyolite of Inlet, } \\
\text { Volcanics of Area } 20\end{array}$ & $\begin{array}{l}\text { Lava flow, devitrified, with flow breccia at } \\
\text { base }\end{array}$ & Tai & 127.1 & 417 \\
\hline $1,450.9--1,585.0$ & $4,760-5,200$ & $\begin{array}{l}\text { Rhyolite of Inlet, } \\
\text { Volcanics of Area } 20\end{array}$ & Moderately welded ash-flow tuff & Tai & 134.1 & 440 \\
\hline $1,585.0-1,644.4$ & $5,200-5,395$ & $\begin{array}{l}\text { Rhyolite of Inlet, } \\
\text { Volcanics of Area } 20\end{array}$ & $\begin{array}{l}\text { Lava flow, devitrified, with minor flow } \\
\text { breccias. }\end{array}$ & Tai & 59.4 & 195 \\
\hline $1,644.4-1,704.8$ & $5,395-5,593$ & $\begin{array}{l}\text { Rhyolite of Inlet, } \\
\text { Volcanics of Area } 20\end{array}$ & $\begin{array}{l}\text { Nonwelded to partially welded ash-flow } \\
\text { tuff, zeolitized }\end{array}$ & Tai & 60.4 & 198 \\
\hline $1,704.8-1,709.9$ & $5,593-5,610$ & $\begin{array}{l}\text { Basalt of Fontina, } \\
\text { Volcanics of Area } 20\end{array}$ & Basalt lava flow & Taf & 5.1 & 17 \\
\hline $1,709.9-1,859.3$ & $5,610-6,100$ & $\begin{array}{l}\text { Tuff of Jorum, } \\
\text { Crater Flat Group }\end{array}$ & Bedded tuff, zeolitized & Tcpj & 149.4 & 490 \\
\hline $1,859.3-2,521.6$ & $6,100-8,273$ & $\begin{array}{l}\text { Mafic-poor, lithic-rich, Bullfrog Tuff, } \\
\text { Crater Flat Group }\end{array}$ & Nonwelded ash-flow tuff, zeolitized & Tcblp & 662.3 & 2173 \\
\hline $2,521.6-2,636.2$ & $8,273-8,649$ & $\begin{array}{l}\text { Comendite of Lambs Canyon, Belted } \\
\text { Range Group }\end{array}$ & $\begin{array}{l}\text { Lava flow, devitrified, with flow breccia at } \\
\text { base }\end{array}$ & Tbdl & 114.6 & 376 \\
\hline $2,636.2-2,974.2$ & $8,649-9,758$ & $\begin{array}{l}\text { Comendite of Kaw Station, Belted Range } \\
\text { Group }\end{array}$ & Flow breccia and lava flow, devitrified & Tbdk & 338 & 1109 \\
\hline
\end{tabular}


Table C-21

Condensed Stratigraphic and Lithologic Log for Exploratory Hole UE-20f

(Page 3 of 3 )

\begin{tabular}{|c|c|c|c|c|c|c|}
\hline \multicolumn{2}{|c|}{ Depth } & \multirow{2}{*}{ Stratigraphic Unit } & \multirow{2}{*}{ Lithology } & \multirow{2}{*}{$\begin{array}{c}\text { Stratigraphic } \\
\text { Symbol }\end{array}$} & \multicolumn{2}{|c|}{ Thickness } \\
\hline . Meters & Feet & & & & Meters & Feet \\
\hline $2,974.2-3,011.1$ & $9,758-9,879$ & $\begin{array}{l}\text { Bedded Grouse Canyon Tuff, Belted } \\
\text { Range Group }\end{array}$ & Nonwelded tuff, zeolitized & Tbgb & 36.9 & 121 \\
\hline $3,011.1-3,118.1$ & $9,879-10,230$ & Tub Spring Tuff, Volcanics of Big Dome & Flow breccia, zeolitized & Tub & 107 & 351 \\
\hline $3,118.1-3,378.7$ & $10,230-11,085$ & Tub Spring Tuff, Volcanics of Big Dome & $\begin{array}{l}\text { Nonwelded to densely welded ash-flow } \\
\text { tuff }\end{array}$ & Tub & 260.6 & 855 \\
\hline $3,378.7-3,542.1$ & $11,085-11,621$. & $\begin{array}{l}\text { Redrock Valley Tuff, Volcanics of Oak } \\
\text { Spring Butte }\end{array}$ & $\begin{array}{l}\text { Moderately welded ash-flow tuff, } \\
\text { zeolitized }\end{array}$ & Tor & 163.4 & 536 \\
\hline $3,542.1-3,610.7$ & $11,621-11,846$ & $\begin{array}{l}\text { Tuff of Twin Peaks, Volcanics of Oak } \\
\text { Spring Butte }\end{array}$ & Moderately welded ash-flow tuff & Tot & 68.6 & 225 \\
\hline $3,610.7-3,671.3$ & $11,846-12,045$ & $\begin{array}{l}\text { Tuff of Burnt Mountain, Volcanics of Oak } \\
\text { Spring Butte }\end{array}$ & Nonwelded and/or bedded tuff, zeolitized & Tom & 60.6 & 199 \\
\hline $3,671.3-3,879.2$ & $12,045-12,727$ & $\begin{array}{l}\text { Volcanics of Oak Spring Butte, } \\
\text { undifferentiated }\end{array}$ & Lava flow & To & 207.9 & 682 \\
\hline $3,879.2-3,953.3$ & $12,727-12,970$ & $\begin{array}{l}\text { Volcanics of Oak Spring Butte, } \\
\text { undifferentiated }\end{array}$ & Nonwelded luff & To & 74.1 & 243 \\
\hline $3,953.3-4,086.2$ & $12,970-13,406$ & $\begin{array}{l}\text { Volcanics of Oak Spring Butte, } \\
\text { undifferentiated }\end{array}$ & Lava flow & To & 132.9 & 436 \\
\hline $\begin{array}{l}4,086.2-4,171.5 \\
\text { (TD) }\end{array}$ & $\begin{array}{c}13,406-13,686 \\
\text { (TD) }\end{array}$ & $\begin{array}{l}\text { Volcanics of Oak Spring Butte, } \\
\text { undifferentiated }\end{array}$ & Moderately welded ash-flow tuff & To & 85.3 & 280 \\
\hline
\end{tabular}

Source: Ferguson, et al., 1994 


\section{Table C-22}

\section{Stratigraphic Nomenclature Used In This Report (listed stratigraphically)}

\section{(Page 1 of 2 )}

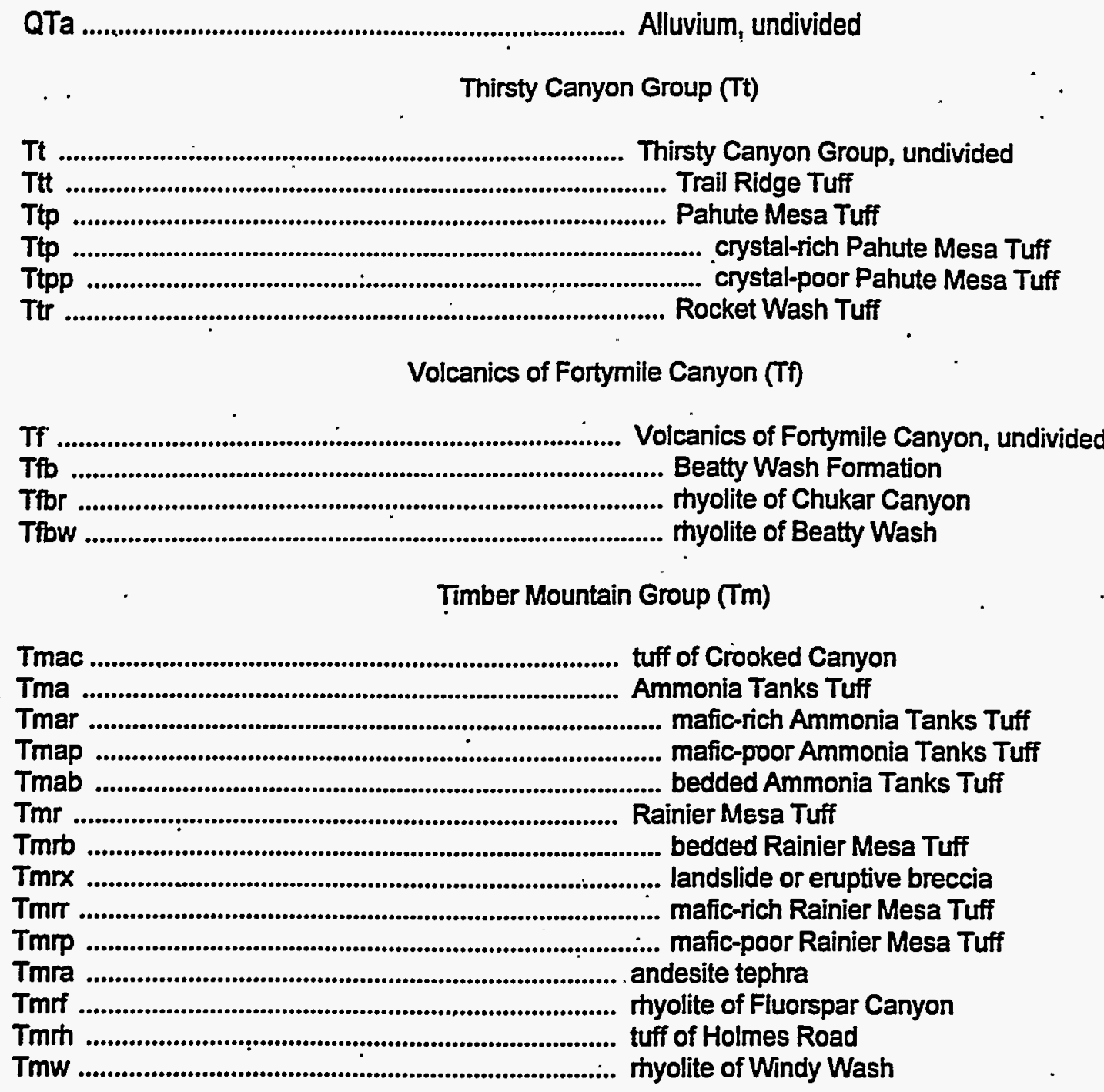

\section{Paintbrush Group (Tp)}

Tp

$\mathrm{Tpb}$

Tps

Tpe

Tpem

Tpd

Tpe

$\mathrm{Tpr}$

Tpt

Tptm

Tptb
Paintbrush Group, undivided myolite of Benham thyolite of Scrugham Peak Tiva Canyon Tuff .. Tiva Canyon Tuff, Pahute Mesa lobe thyolite of Delirium Canyon inyolite of Echo Peak myolite of Silent Canyon Topopah Spring Tuff Topopah Spring Tuff, Pahute Mesa lobe bedded Topopah Spring Tuff 


\section{Table C-22 \\ Stratigraphic Nomenclature Used In This Report (listed stratigraphically) (Page 2 of 2)}

Volcanics of Area 20 (Ta)

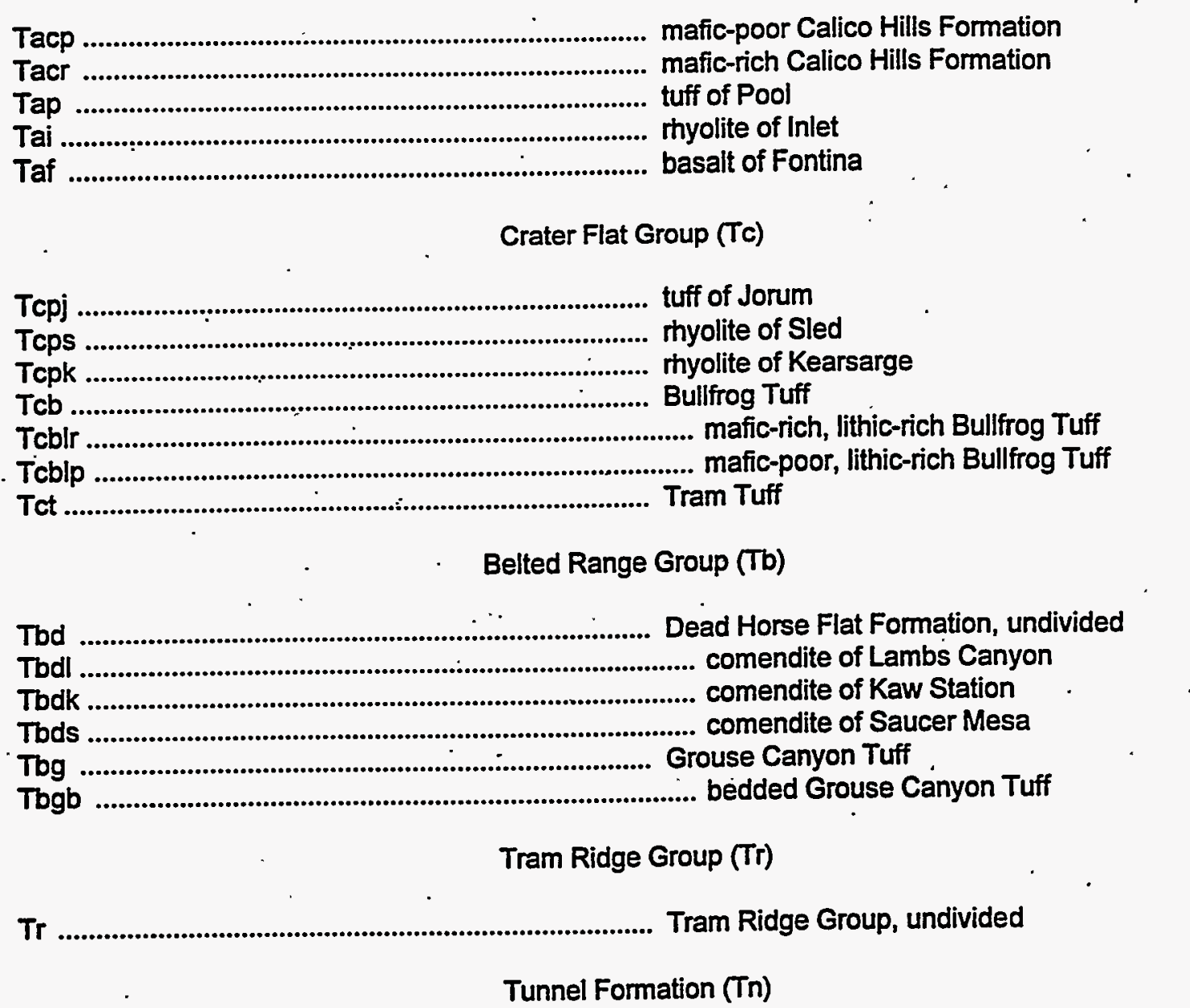

Tn4

Tn4JK

Tunnel 4 Member Tunnel 4 Member, beds $4 \mathrm{~J}$ and $4 \mathrm{~K}$

\section{Volcanics of Big Dome (Tu)}

Tuq

Tub comendite of Quartet Dome Tub Spring Tuff

\section{Volcanics of Oak Spring Butte (To)}

To

Tor

Tot

Tom
Volcanics of Oak Spring Butte, undivided Redrock Valley Tuff tuff of Twin Peaks tuff of Burnt Mountain

Volcanics of Quartz Mountain

$\mathrm{Tq}$

Tq̣m
Volcanics of Quartz Mountain, undivided Dacite of Mt. Helen 
Table C-23

Lithologic and Alteration Nomenclature

Used In This Report

\begin{tabular}{||c|l||}
\hline \hline Symbol & \multicolumn{1}{|c|}{ Lithology } \\
\hline \hline AL & Alluvium \\
B & Bedded tuff \\
RWT & Reworked tuff \\
NW & Nonwelded tuff \\
PW & Partially welded tuff \\
MW. & Moderately welced tuff \\
DW & Densely welded tuff \\
V & Vitrophyre \\
L & Lava \\
PL & Pumiceous lava \\
FB & Flow breccia \\
TB & Tuff breccia \\
\hline \hline Symbol & \multicolumn{1}{|c||}{ Alteration } \\
\hline \hline A & Argillized \\
Z & Zeolitized \\
V or gl & Vitric (glassy) \\
D or dv & Devitrified \\
VP & Vapor-phase mineralization \\
\hline \hline
\end{tabular}


This page intentionally left blank. 


\section{Distribution List}

Copies

DOE Office of Scientific and Technical Information, Oak Ridge, TN 2

DOE/NV Technical Information Resource Center, Las Vegas, NV 1

DOE/NV Public Reading Room, Las Vegas, NV . 1

R. M. Bangerter, DOE/ERD. Las Vegas, NV 1

D. W. Duncan, DOE/ERD, Las Vegas, NV 1

R. Andricevic, DRI, Las Vegas, NV 1

C. E. Russell, DRI, Las Vegas, NV 1

C. Shirley, DRI, Las Vegas, NV $\quad$ ' 1

P. D. Rowley, USGS, Las Vegas, NV 1

J. E. Magner, USGS Geologic Data Center, Mercury, NV 1

D. A. Trudeau, USGS/WRD, Las Vegas, NV ' 1

A. B. Kersting, LLNL, Livermore, CA . 1

G. A. Pawloski, LLNL, Livermore, CA 1

D. K. Smith, LLNL, Livermore, CA 1

A. Tompson, LLNL, Livermore, CA 1

D. L. Finnegen, LANL, Los Alamos, NM ' •

W. L. Hawkins, LANL, Los Alamos, NM · . 1

M. A. McGraw, LANL, Los Älamos, NM · 1

P. W. Reimus, LANL, Los Alamos, NM 1

R. G. Warren, LANL, Los Alamos, NM 1

A. V. Wolfsberg, LANL, Los Alamos, NM 1

Library, IT Corp., Las Vegas, NV . 1

E. H. Price, HSI GeoTrans, Las Vegas, NV

- K. R. Rehfeldt, HSI GeoTrans, Las Vegas, NV 1

R. K. Waddell, HSI GeoTrans, West Minster, CO 1

B., M. Allen, BN, Mercury, NV .

H. S. Bensinger, BN, Las Vegas, NV 1

S. L. Drellack, BN, Las Vegas, NV • 1

J. L. Gonzales, BN, Las Vegas, NV 1

P. K. Ortego, BN, Las Vegas, NV. 1

L. B. Prothro, BN, Mercury, NV 1

M. J. Townsend, BN, Mercury, NV 1 